Ibn Taymiyya's Theodicy of Perpetual Optimism 


\title{
Islamic Philosophy, Theology and Science
}

\author{
Texts and Studies
}

\author{
Edited by
}

H. Daiber

VOLUME LXXIII 


\title{
Ibn Taymiyya's Theodicy of Perpetual Optimism
}

\author{
by \\ Jon Hoover
}

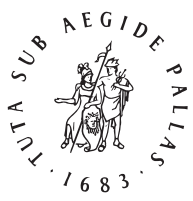

B R I L L

LEIDEN • BOSTON

2007 


\section{B R I L L This is an open access title distributed under the terms of the Creative \\ O P E N Commons Attribution-Noncommercial 3.0 Unported (CC-BY-NC 3.0) License, which permits any non-commercial use, distribution, and reproduction in any medium, provided the original author(s) and source are credited.}

ISSN $0169-8729$

ISBN 9789004158474 (hardback)

ISBN 9789047420194 (e-book)

\section{Copyright 2007 by Jon Hoover}

This work is published by Koninklijke Brill NV. Koninklijke Brill NV incorporates the imprints Brill, Brill Nijhoff, Global Oriental and Hotei Publishing.

Koninklijke Brill NV reserves the right to protect the publication against unauthorized use and to authorize dissemination by means of offprints, legitimate photocopies, microform editions, reprints, translations, and secondary information sources, such as abstracting and indexing services including databases. Requests for commercial re-use, use of parts of the publication, and/or translations must be addressed to Koninklijke Brill NV.

This book is printed on acid-free paper. 
TO MY MOTHER AND FATHER 



\section{CONTENTS}

Acknowledgements …………………………………………………....

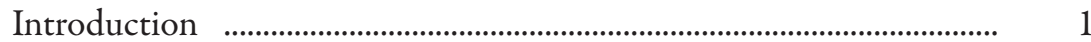

Chapter One: Worship, Religious Epistemology and Theological Jurisprudence ....................................................................................... 19

Ibn Taymiyya as a Theological Jurist ……………………………….... 19

The Centrality of Worshipping God Alone .................................... 26

The Correspondence of Reason and Revelation ............................... 29

On Knowing that God Exists and that He Alone should

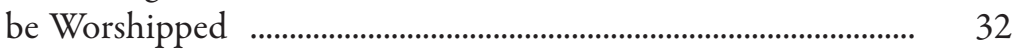

The Methodology of Theological Jurisprudence …………………... 46

The Apologetic Quality of Ibn Taymiyya’s Theological

Jurisprudence

Chapter Two: God's Wise Purpose, Perpetual Activity and Self-Sufficiency

The Problematic of God's Goodness and God's

Self-Sufficiency

Joseph Bell on God's Wise Purpose and Self-Sufficiency

in Ibn Taymiyya's Theology

Ibn Taymiyya's Classification of Views on Wise Purpose/

Causality in the Will of God

The Ash'arī Case against Causality in the Will of God:

It Entails Imperfection and Origination in God, as well as an Infinite Regress

Ibn Taymiyya's Case for a God Who Acts Perpetually for

Wise Purposes and Creates from Eternity

Ibn Taymiyya on God's Voluntary Acts Subsisting in

God's Essence

Ibn Taymiyya on God's Sufficiency apart from the

Worlds in the Exercise of Wise Purpose

Conclusion 
Chapter Three: God's Creation and God's Command ........................ 103

Ibn Taymiyya's Creation/Command Hermeneutic ........................... 103

Ibn Taymiyya's Classification of Errors in Creation and

Command

Ibn Taymiyya: Analogy Is the Cause of Error in Creation and Command

Modes of Expressing Creation and Command in Ibn Taymiyya's Thought

Ibn Taymiyya Defending the Coherence of Creation and Command

Conclusion

Chapter Four: God's Creation of Acts in the Human Agent

Ibn Taymiyya's View of the Human Act in Prior

Research

The Theological and Philosophical Context

Ibn Taymiyya on the Compatibility of Divine Creation and Human Action

Ibn Taymiyyas View of Divine Creation by Means of Secondary Causes

Ibn Taymiyya on Controversial Kalām Terms Relating to Human Agency

Ibn Taymiyya’s Compatibilism as the Golden

Mean (wasat)

Conclusion

Chapter Five: The Wise Purpose and Origin of Evil

Ibn Taymiyya and the Explanation of Evil in Islamic

Theodicies

Ibn Taymiyya's Evil Attribution Typology

Ibn Taymiyya on God's Wise Purposes in the Creation of Evil

Ibn Taymiyyas Location of the Origin of Evil in

Nonexistence ('adam)

Conclusion 
Chapter Six: The Justice of God and the Best of All Possible

Worlds

Introduction

Ibn Taymiyya's Three-fold Typology on God's Justice

( $a d l)$

Ibn Taymiyya on God's Power and al-Ghazālī’s Best of

All Possible Worlds

Conclusion

Conclusion

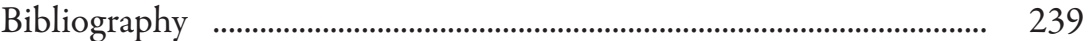

Ibn Taymiyya's Writings ................................................................. 239

Collected Works with Abbreviations ........................................... 239

Ibn Taymiyya's Treatises with Short Titles ..................................... 239

Works of Others Found in the Collected Works of Ibn Taymiyya ………............................................................................. 243

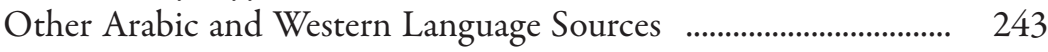

Index 



\section{ACKNOWLEDGEMENTS}

This book is a substantial reworking of my 2002 University of Birmingham Ph.D. entitled, "An Islamic Theodicy: Ibn Taymiyya on the Wise Purpose of God, Human Agency, and Problems of Evil and Justice." David Thomas gently guided and nurtured my doctoral research through many a blind alley. Yahya Michot gave the doctoral thesis text a careful critique and drew my attention to aspects of Ibn Sinnā in Ibn Taymiyya. Both shared generously of their time, and their incisive questions, observations, corrections and suggestions spurred me on to what I trust is now a more accurate reading of Ibn Taymiyya's theodicy.

Many others have engaged me in conversations that provided encouragement, taught me much of relevance to Ibn Taymiyya, challenged me to think deeper about what I was doing, and saved me from errors and oversights. In this regard, I wish to thank especially Muammer İskenderoğlu, Maha Elkaisy-Friemuth, Giuseppe Scattolin, Frank Griffel, David Vishanoff, Shahab Ahmed, Livnat Holtzman, Caterina Bori, Mairaj Syed, Tariq el-Jamil, David Grafton, Gino Schallenbergh, Aron Zysow, Luciano Verdoscia, Khaled el-Rouayheb, Mark Swanson and Christian van Nispen. The Center for Arabic and Middle Eastern Studies at the American University of Beirut and its director John Meloy kindly provided access to the research and library resources needed to bring this book to completion. Michael Shelley and Marc Schoeni read through the entire text at different stages of preparation and offered their valuable perspectives as educated readers from outside the sub-discipline of Islamic philosophy and theology. Trudy Kamperveen at Brill guided the process of publication with eminent care and professionalism.

It has been my privilege to be part of supportive institutions throughout this endeavor. Professors, staff and fellow students at the Centre for the Study of Islam and Christian Muslim Relations in the University of Birmingham offered friendship and rich dialogue. Colleagues, staff and students at Dar Comboni for Arabic Studies in Cairo and now the Near East School of Theology in Beirut have graciously abided my ongoing interest in Ibn Taymiyya and provided much stimulating conversation.

My gratitude extends as well to my parents to whom this book is dedicated and to the numerous people of vision in the Mennonite churches of the United States and Canada for making this undertaking possible in so many different ways. I also owe a great debt to my wife and children for bearing 
with me through the grueling process of study and granting me the daily joy and warmth of life in family. Last, but certainly not least, I give thanks to God who in love and mercy has seen me through this project. While this study would not have been possible without so much help graciously given, I remain fully responsible for its deficiencies.

Portions of Chapter Two and much of Chapter Six were published previously in the Theological Review of the Near East School of Theology as "Ibn Taymiyya as an Avicennan Theologian: A Muslim Approach to God's SelfSufficiency," 27.1 (April 2006): 34-46, and "The Justice of God and the Best of All Possible Worlds: The Theodicy of Ibn Taymiyya," 27.2 (November 2006): 53-75, respectively. I am grateful to the editor for permission to republish here with revisions and additions. 


\section{INTRODUCTION}

\section{Theodicy and Ibn Taymiyya}

The eminent Muslim jurist Ibn Taymiyya (d. 728/1328) is well known for polemic against all manner of rational thought, whether the Neoplatonic philosophy of Ibn Sīnā (Avicenna), the mystical speculation of Ibn 'Arabī, or the Kalām theology of the Ash'arīs and the Mu'taziliss. Furthermore, Ibn Taymiyya's resolute adherence to the Qur'an, the Sunna and the Salaf (i.e. the pious early Muslims) is nearly legendary. Yet, scattered about in specialized studies are hints that there is more to the shaykh than polemics and unyielding literalism. While polemics and literalism are indeed prominent features of Ibn Taymiyya's writing, it is growing ever more apparent that their import is not fully grasped without reference to a broader method and theological vision at work in his thought. Perhaps even more surprising is that Ibn Taymiyya shares with Ibn Sīnā and Ibn 'Arabī, as well as with al-Ghazālī in his Ihy $\vec{a}$ ' ulüm al-din, a similar stance on one of the most fundamental questions of monotheistic theology, that of theodicy.

The term theodicy as used in modern western philosophy of religion indicates the attempt to explain why a good, just and all-powerful God created a less than perfect world. The term is not indigenous to the Islamic tradition, and a major current within the tradition — the voluntarism of Ash ' arī Kalām theology-rejects the question of theodicy as meaningless. God's unfettered will, sufficiency apart from the world, and exclusive power preclude asking why God does this or that. God is not limited by any necessity of reason, and His acts require no deliberation, rational motive or external cause. Thus, God's creation of injustice, unbelief and other evils is not susceptible to any explanation except that God wills it.

Despite this, theodicy and its division into two basic kinds-the bestof-all-possible-worlds theodicy, also known as optimism, and the free-will theodicy-prove useful as analytical shorthand for sorting through other theological currents in the Islamic tradition. ${ }^{1} \mathrm{Mu}^{\mathrm{C}}$ tazili Kalām theology provides the primary instance of an Islamic free-will theodicy. While the

${ }^{1}$ I owe this conceptual distinction to Marilyn McCord Adams, Horrendous Evils and the Goodness of God (Ithaca, NY: Cornell University Press, 1999), 179, and passim.

(C) Jon Hoover, 2007

This is an open access chapter distributed under the terms of the http://creativecommons.org/licenses/by-nc/3.0/. 
Mu'taziliss uphold God's sufficiency apart from the world along with the Ash'arīs, they also introduce purpose into God's creation. They explain that God creates human beings not out of His own need but for the benefit of humans themselves, which is to work for reward in the retributive order of obligations that God has imposed. Within this order God must do what is best (aslab) for all creatures in respect of religion, and, according to some Mu'tazilīs, in mundane matters as well. Humans for their part have free will and create their own good and bad deeds apart from God's control. God is therefore just to reward and punish. If God were the sole creator of all human acts, He would obviously be unjust to punish the unbelief and disobedience that He creates.

Optimism or the best-of-all-possible-worlds theodicy appears in more than one strand of the Islamic tradition. An early instance occurs in the Kalām theology of al-Māturììi (d. 333/944) for whom evil serves the peculiar function of proving the existence of God. God creates all things, including evil, in conformity to His wisdom, and, by virtue of evil's opposition to good, evil shows the contingency of the creation and its need for the Creator. Evil is thus a tool of God's wisdom to lead human beings to knowledge of God. ${ }^{2}$

While al-Māturīdi serves as the eponym for the important Māturīdì school of Kalām theology, Ibn Sīnā (d. 428/1037) and his doctrine of providence ('inäya) provide the key conceptual resources for the development of optimism in the other major strands of the Islamic tradition. For Ibn Sinnā, providence means that the First (i.e. God) is the source of the best possible order: the First is "a cause in Itself of good and perfection inasmuch as that is possible (bi-hasab al-imkann)."3 Similarly, the knowledge of the First necessarily entails that the existence of everything is "according to the best order ('alä ahsan al-nizām)." "Evil in Ibn Sinäs view does not truly exist. It is rather a privation of being or existence, and it is a necessary consequence of and a means to the greater good that God providentially wills in creation. ${ }^{5}$

2 J. Meric Pessagno, “The uses of Evil in Maturidian Thought," Studia Islamica 60 (1984): 59-82.

${ }_{3}^{3}$ Ibn Sīnā, Al-Shifǟ: Al-Ilāhiyyāt (2), ed. Muhammad Yūsuf Mūsā, et al. (Cairo: Al-Hay’a al-āmma li-shu'ūn al-mațābi' al-amīriyya, 1380/1960), 415.

${ }^{4}$ Ibn Sīnā, Al-Ishārāit wa al-tanbīhāt (Ed. Sulaymān Dunyā. 3 vols. Cairo: Dār ihyāā al-kutub al-'arabiyya, 1366-67/1947-48), 3:206. Ibn Siñā explains the providentially good ordering of the heavens and the earth in Al-Mabda' wa al-ma'àd, ed. 'Abd Allāh Nürānī (Tehran: Institute of Islamic Studies, McGill University-Tehran University, 1984), 88-90.

${ }^{5}$ Ibn Sīnā, Al-Shifä: Al-Ilāhiyyāt (2), 414-422. Mūnā Aḥmad Muhammad Abū Zayd offers a wide ranging overview of Ibn Sinnäs thought on evil in Mafhüm al-khayr wa al-sharr fì al-falsafa al-Islämiyya: Dirāsa muquarana fì fikr Ibn Sìnā (Beirut: Al-Mu'assasa al-jāmi'iyya li-l-dirāsāt wa al-nashr wa al-tawzî́', 1411/1991). See also Shams C. Inati, The Problem of 
Optimism is also widespread in Sufism. Sufis do not always speculate whether this world is the best possible, but they do typically affirm that God creates evil as an instrument of discipline on the spiritual path. Annemarie Schimmel sums up this perspective as follows: "The mystic can understand that God's wrath is mercy in disguise, and that the pain and punishment that He inflicts upon those who love Him are necessary for their spiritual growth-just as bitter medicine is necessary for the sick." ${ }^{\prime \prime}$ In the more philosophical vein of Sufism, which draws on Avicennan conceptual resources, al-Ghazāil (d. 505/1111) sparked a debate lasting eight centuries with the claim, "There is nothing in possibility more wonderful than what is (laysa fì al-imkan abdà mimma kān)," and Ibn 'Arabī (d. 638/1240) integrated optimism fully into his prodigious and influential mystical writings.?

Also ranking with Muslim optimists is Ibn Taymiyya, as well as his most illustrious student Ibn Qayyim al-Jawziyya (d. 751/1350). This has gone almost completely unnoticed in basic works on Islamic philosophy and theology in western languages. ${ }^{8}$ Yet, observation of Ibn Taymiyya's optimism is not new. Joseph Bell broke important ground on several aspects of the shaykh's theodicy in his 1979 Love Theory in Later Hanbalite Islam, which I will review in Chapter Two below, ${ }^{9}$ and, 40 years earlier, Henri Laoust in

Evil: Ibn Sinẩs Theodicy (Binghamton, NY: Global Publications, Institute of Global Cultural Studies, Binghamton University, 2000); Jean R. Michot, La destinée de l'homme selon Avicenne (Louvain: Peeters, 1986), 61-66; and Marwan Rashed, "Théodicée et approximation: Avicenne," Arabic Sciences and Philosophy 10 (2000): 223-257.

${ }^{6}$ Annemarie Schimmel, Mystical Dimensions of Islam (Chapel Hill, NC: The University of North Carolina Press, 1975), 198. Louis Massignon provides evidence for the instrumental role of suffering in Sufism in The Passion of al-Halläj: Mystic and Martyr of Islam, trans. Herbert Mason (Princeton, NJ: Princeton University Press, 1982), 3:111-121.

7 On al-Ghazāli and the subsequent controversy, see Eric L. Ormsby, Theodicy in Islamic Thought: The Dispute over al-Ghazälìs' "Best of all Possible Worlds" (Princeton, NJ: Princeton University Press, 1984). I survey Ormsby's work at the end of Chapter Six. For a reminder that al-Ghazälīs theological views are not easily harmonized into a coherent position, see Norman Calder's review of Ormsby's book in Bulletin of the School of Oriental and African Studies 49 (1986): 211-2. For Ibn 'Arabī see Ormsby, Theodicy, 103-7, and more comprehensively, William C. Chittick, The Sufi Path of Knowledge: Ibn al-'Arabi's Metaphysics of Imagination (Albany, NY: State University of New York Press, 1989), especially 289-301.

8 The sole mention of Ibn Taymiyya's optimism that I have found in introductory works occurs in Fazlur Rahman, Islam, 2d ed. (Chicago: University of Chicago Press, 1979), 113-4, who notes approvingly, although inaccurately in the case of the Māturīdīs, that "Ibn Taymìya reinstates into Muslim theology the doctrine of the purposiveness of the Divine behaviour, a doctrine so strenuously denied by Ash'arism, Māturīdism and Zāhirism as compromising the omnipotence of God's will and His dissimilarity to His creation." Unfortunately, Rahman does not explore the implications of this in Ibn Taymiyya's theology further.

9 Joseph Normant Bell, Love Theory in Later Hanbalite Islam (Albany, NY: State University of New York Press, 1979), 46-91. 
his still unsurpassed 1939 Essai sur les doctrines sociales et politiques de Taki$d$-Din Ahmad b. Taimiya concisely described the shaykh's theodicy thus:

God is essentially providence. Evil is without real existence in the world. All that God has willed can only conform to a sovereign justice and an infinite goodness, provided, however, that it is envisaged from the point of view of the totality and not from that of the fragmentary and imperfect knowledge that His creatures have of reality... Ibn Taymiyya's theodicy marks the advent in Sunnī dogmatics of an optimism of Platonic inspiration which will be more amply and more literarily developed in the oeuvre of Ibn Qayyim al-Jawziyya. ${ }^{10}$

Unfortunately, Laoust says little more than this about Ibn Taymiyya's theodicy, and, buried away in Laoust's encyclopedic tome, its significance has not been recognized. The present study seeks to rectify this by drawing together Ibn Taymiyya's thought on the sundry questions that come under the rubric of theodicy and expositing, analyzing and occasionally translating his theodicean writings. I also examine the shaykh's intellectual context in order to shed light on his theodicy's location in the wider Islamic tradition and trace precedents for his thought. A great deal more remains to be done in this regard, but the contextualizing work done here should be sufficient to show that Ibn Taymiyya articulates a best-of-all-possible-worlds theodicy over against traditional Ash'arism and Mu'tazilism that follows in the train of Ibn Sīnā, Ibn 'Arabī and al-Ghazālīi, whatever his differences with these renowned figures on other counts. Attention is given as well to the theological method at work in Ibn Taymiyya's theodicy, and more will be said about this at the end of this Introduction.

It becomes apparent in the course of this study that Laoust's brief analysis of Ibn Taymiyyas's place in the Islamic tradition quoted above requires modification and elaboration. As for the inspiration of Ibn Taymiyya's theodicy, Ibn Sinā is more proximate than Plato, although Plato certainly lies in the distant background. Additionally, inasmuch as al-Māturīdī and al-Ghazālī come earlier, Ibn Taymiyya does not mark the beginnings of optimism in Sunnī theology. Nonetheless, his theodicy might be original in another significant respect. The shaykh combines a best-of-all-possible-worlds theodicy with a dynamic vision of God's essence. Ibn Taymiyya's God, who is perpetually active and creative from eternity, contrasts sharply with the ultimately timeless and motionless God of not only Ibn Sinnā and his successors but also the

${ }^{10}$ Henri Laoust, Essai sur les doctrines sociales et politiques de Taki-d-Din Abmad b. Taimiya, canoniste hanbalite né à Harrān en 661/1262, mort à Damas en 728/1328 (Cairo: Imprimerie de l'institut français d'archéologie orientale, 1939), 169, cf. 515. 
Kalām theologians. It is because of the unique character of Ibn Taymiyya's God as ever active in a temporal sense that I call his optimism "perpetual." This will become readily apparent in Chapter Two below.

Ibn Taymiyya's theodicy has not been without interest to later generations of Muslims. As Laoust correctly observes, Ibn Qayyim al-Jawziyya provides a more fully developed optimism than does Ibn Taymiyya himself, although the disciple's theodicy and its debt to his master have yet to be studied carefully. ${ }^{11}$ Perhaps more significantly, Ibn Taymiyya is well known today as a major inspiration for contemporary Islamic resurgence, and it is common knowledge among students of modern Islam that the writings of the shaykh are important sources for the eighteenth and nineteenth century Wahhābī movement in Arabia and modernist reformers such as Rashīd Riḍā (d. 1935). ${ }^{12}$ While modern Muslim interest in Ibn Taymiyya is often thought to be social and political, there is anecdotal evidence that it extends to theodicy as well. The direct influence of Ibn Taymiyya's optimism is found in such diverse places as the work of the prominent Pakistani modernist Fazlur Rahman (d. 1988) and a detailed volume on good and evil published

${ }^{11}$ A major source for Ibn Qayyim al-Jawziyya's theodicy is Shifä al-'alìl fì masä̉il al-qad $\vec{a}$ wa al-qadar wa al-hikma wa al-tálïl, ed. al-Sayyid Muhammad al-Sayyid and Sa īid Mahmūd (Cairo: Dār al-Hadìith, 1414/1994). Irmeli Perho, "Man Chooses his Destiny: Ibn Qayyim al-Jawziyya's view on predestination," Islam and Christian-Muslim Relations 12 (2001): 61-70, provides access to the basic ideas found in the first part of this work, but the scope of her article does not extend to the questions of wise purpose and causality in God's will that are treated later in the book. Of the thirty chapters in Shifä al-'alìl, A. de Vlieger, Kitâb al qadr: Matériaux pour servir a l'étude de la doctrine de la prédestination dans la théologie musulmane (Leiden: E.J. Brill, 1903), 116-169, translates parts of Chapters 7-12 and 17, which deal primarily with divine determination. Also of interest on Ibn Qayyim al-Jawziyya are Bell, Love Theory, 92-181; and Moshe Perlmann, "Ibn Qayyim and the Devil," in Studi Orientalistici in onore di Giorgio Levi della Vida, vol. 2 (Rome: Istituto per l'oriente, 1956), 330-7.

${ }_{12}$ For Ibn Taymiyyas influence from his death through to early twentieth century Egyptian reform movements, see Laoust, Essai, 477-575; and Laoust, "L'influence d'Ibn-Taymiyya," in Islam: Past Influence and Present Challenge, ed. Alford T. Welch and Pierre Cachia (Edinburgh: Edinburgh University Press, 1979), 15-33. Ibn Taymiyya is seen widely today as the key inspiration for contemporary Islamic militancy, primarily because militants quote him as a key authority. However, accepting this linkage uncritically, as does Natana J. Delong-Bas, Wahhabi Islam: From Revival and Reform to Global Jihad (Oxford, UK: Oxford University Press, 2004), 247ff., is anachronistic and distorts Ibn Taymiyya into a more militant figure than he was. For antidotes to this problem, see Emmanuel Sivan, "Ibn Taymiyya: Father of the Islamic Revolution: Medieval Theology \& Modern Politics," Encounter 60.5 (May 1983): 41-50; Johannes J.G. Jansen, "Ibn Taymiyyah and the Thirteenth Century: A Formative Period of Modern Muslim Radicalism," 2uaderni di Studi Arabi 5-6 (1987-8): 391-6; Paul L. Heck, "Jihad Revisited," Journal of Religious Ethics 32 (2004): 95-128; and Yahya Michot, trans., Ibn Taymiyya: Mardin: Hégire, fuite du péché et «demeure de l'Islam» (Beirut: Dar Al-Bouraq, 1425/2004). 
in Egypt by Muhammad al-Sayyid al-Julaynad. ${ }^{13}$ It may well be that Ibn Taymiyya writings, as well as those of Ibn al-Qayyim, are nurturing a broad movement of optimism in modern Islamic discourse. However, it is beyond the scope of the present book to examine the degree to which this is so, especially as this merits a major inquiry in its own right. An important aim of the present study is to provide a far firmer foundation than has previously been available for research of that kind.

\section{Ibn Taymiyya's Theodicean Writings}

Ibn Taymiyya wrote voluminously and often polemically on a wide range of issues in an effort to purge Islam of various innovations that he perceived it to have suffered and to illumine the pure religion of the Qur'an, the Sunna and the Salaf. ${ }^{14}$ His output as a scholar was complemented and shaped by

${ }^{13}$ For Fazlur Rahman see Note 8 above and his Revival and Reform in Islam: A Study of Islamic Fundamentalism (Oxford: Oneworld Publications, 2000), 148-156. Muhammad al-Sayyid al-Julaynad, Qadiyyat al-khayr wa al-sharr fì al-fikr al-islämì: Ușüluha al-nazariyyajawānibuhà al-tatbiqqiyya, Dirāsa 'ilmiyya li-mas'üliyyat al-insān fì al-Isläm, 2d Printing (Cairo: Mațba'at al-Halabì, 1981), provides a study of the Mu'tazilī and Ash'arī Kalām traditions on good and evil, evaluating both with the help of numerous references and borrowings from Ibn Taymiyya and Ibn Qayyim al-Jawziyya (e.g. 108-114, 134, 177-181, 205-213, 234-242, 261-2, 278-9, 298-303, and 320-1). 'Umar Sulaymān al-Ashqar, 'Älam al-jinn wa al-shayyätin (Cairo: Bayt al-Hikma, 1413/1992), 155-167, borrows directly from Ibn Qayyim al-Jawziyya's Shifä al-' alì to explain God's wise purpose in the creation of Satan. This is translated as Umar Sulaiman al-Ashqar, The World of the Jinn and Devils, trans. Jamaal alDin M. Zarabozo, (Boulder, CO: Al-Basheer, 1998). Laoust, Essai, 515-6, observes that the modern Najdī scholar Sulaymān b. Saḥmān (d. 1349/1930) adopts Ibn Taymiyya’s optimism but that Ibn 'Abd al-Wahhāb is much more Ash'arī. For the influence of Ibn Taymiyya's notion of divine determination (qadar) on Muhammad Rashīd Riḍā, see Christian van Nispen Tot Sevenaer, Activité Humaine et Agir de Dieu: Le Concept de 'Sunan de Dieu' dans le commentaire coranique du Manar (Beyouth: Dar el-Machreq, 1996), 264-5, 483-4.

${ }_{14}$ A manuscript giving an extensive list of Ibn Taymiyyas works has been attributed to Ibn Qayyim al-Jawziyya and printed as $A s m \vec{a} m u$ 'allafät Ibn Taymiyya, ed. Șalāh al-Dīn al-Munajjid (Damascus: Maṭbū āt al-majma cal-ilmī al-'arabī, 1953). Using an additional manuscript source, Muhammad 'Uzayr Shams and 'Alī b. Muhammad 'Imrān have reedited this in Al-Jämi' li-sīrat Shaykh al-Isläm Ibn Taymiyya (661-728) khiläl sab' at qurün, with an introduction by Bakr b. 'Abd Allāh Abū Zayd (Mecca: Dār 'ālam al-fawāìd, 1420/1999-2000), 220-249. Shams and 'Imrān, Al-Jāmi', 8-13, also reject Ibn Qayyim al-Jawziyya's authorship and attribute it to another of Ibn Taymiyya's close followers Ibn Rushayyiq (d. 749/1348-9) on the basis of two arguments. First, Ibn Taymiyya's main biographer Muhammad b. Ahmmad b. 'Abd al-Hādī (d. 744/1343), Al''Uqüd al-durriyya min manäqib Shaykh al-Isläm Ahmad b. Taymiyya (Beirut: Dār al-kutub al-ilmiyya, n.d.), 26-7, copied a page from the list's preface, attributed it to Ibn Rushayyiq, and credited him with compiling a list. (Ibn 'Abd al-Hādī, $A l^{\prime} U_{q u}$ al-durriyya, 27-67, also provides a list of works, which has its own purposes and does not correspond exactly to that attributed to Ibn Rushayyiq.) Second, although Ibn Qayyim 
his vocation as the most prominent religious activist in the Bahrī Mamlūk sultanate of Egypt and Syria. The shaykh called for jihad against Mongol incursions from the east that threatened Mamlūk sovereignty in Syria, and, while he may have been a Sufi himself, he actively opposed Sufi and popular religious practices that he believed were in violation of the sacred Law. Refusal to compromise on his allegedly anthropomorphic doctrine of God's attributes brought him public trials, imprisonment and a seven-year stay in Egypt (705-712/1306-1313). Ibn Taymiyya spent his last two years of life (726-8/1326-8) incarcerated in the citadel of Damascus for his criticism of tomb visitation and the cult of saints. ${ }^{15}$

al-Jawziyya and Ibn Rushayyiq share the same kunya Abū 'Abd Allāh, references to Abū 'Abd Allăh undertaking a compilation of Ibn Taymiyya's works found in an account by his disciple Ibn Murrī (included in Shams and 'Imrān, Al-Jämi', 97-104) fit much better with what is otherwise known about Ibn Rushayyiq than with our information on Ibn Qayyim al-Jawziyya. These arguments allow very likely, although perhaps not definitive, attribution of this list to Ibn Rushayyiq. Significant lists of Ibn Taymiyyas writings are also found in

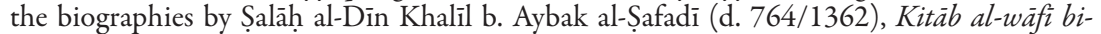
l-wafayāt, vol. 7, ed. Iḥsān 'Abbās (Wiesbaden: Franz Steiner, 1969), 23-30; Muḥammad b. Shākir al-Kutubī (d. 764/1362), Fawāt al-wafayyāt wa al-dhayl 'alayhā, ed. Ihsān 'Abbās (Beirut: Dār Șādir, 1973), 1:75-80; and Ibn Rajab (d. 795/1393), Kitāb al-dhayl' alā țabaqāt al-hanābila, (Cairo: Mațba'at al-sunna al-muhammadiyya, 1372/1953), 2:403-4. Ibn Rajab notes that it is impossible to account for everything Ibn Taymiyya wrote.

${ }^{15}$ Shams and 'Imrān, Al-Jämi', bring together the pre-modern biographies of Ibn Taymiyya, including those mentioned in the previous note. Available separately is a biography by Shams al-Din al-Dhahabì (d. 748/1347-8) in Caterina Bori, "A new source for the biography of Ibn Taymiyya," Bulletin of the School of Oriental and African Studies 67.3 (2004): 321-348, which contains both the Arabic and an English translation. For analysis of the Arabic biographies and chronicle reports concerning Ibn Taymiyya, see Donald P. Little, "The Historical and Historiographical Significance of the Detention of Ibn Taymiyya," International Journal of Middle East Studies 4 (1973): 311-327; and An Introduction to Mamlük Historiography: An Analysis of Arabic Annalistic and Biographical Sources for the Reign of al-Malik an-Näsir Muhammad ibn Qalä'ün, (Wiesbaden: Franz Steiner Verlag, 1970). Modern discussions of Ibn Taymiyya's life include Caterina Bori, Ibn Taymiyya: una vita esemplare Analisi delle font $i$ classiche della sua biografia, Supplemento N. 1., Rivista Degli Studi Orientali, Vol. 76 (Pisa/ Roma: Istituti Editoriali e Poligrafici Internazionali, 2003); and various works of Henri Laoust: Essai, 7-150; "La biographie d'Ibn Taimīya d'après Ibn Kațîr," Bulletin d'études orientales 9 (1942-3): 115-162; "Le Hanbalisme sous les Mamlouks Bahrides (658-784/1260-1382)," Revue des études islamiques 28 (1960): 1-71; and "Ibn Taymiyya," The Encyclopedia of Islam, New edition [hereafter EI2] (Leiden: E.J. Brill, 1954-2004), 3:951-5. Hasan Qasim Murad, "Ibn Taymiya on Trial: A Narrative Account of his Mihan," Islamic Studies 18 (1979): 1-32, focuses on the shaykh's various trials. On the trials over anthropomorphism, see especially Sherman A. Jackson, "Ibn Taymiyyah on Trial in Damascus," Journal of Semitic Studies 39 (Spring 1994): 41-85. George Makdisi locates Ibn Taymiyyas silsila in "Ibn Taimīya: A Sufi of the Qàdiriya Order," American Journal of Arabic Studies 1 (1973): 118-129, and of related interest is George Makdisi, "The Hanbali School and Sufism," Boletin de la Asociacion Espanola de Orientalistas 15 (1979): 115-126, reprint as Part V in George Makdisi, Religion, Law and Learning in Classical Islam (Hampshire, UK: Variorum, 1991). There is also substantial biographical material on Ibn Taymiyya in the introduction to Jean R. 
Certain difficulties attend research in Ibn Taymiyya's theodicean writings. $\mathrm{He}$ often presumes in the reader a substantial knowledge of the Islamic religious tradition, and, in comparison to the full didactic style of his disciple Ibn Qayyim al-Jawziyya, Irmeli Perho aptly observes, "Ibn Taymiyya wrote very sparse prose and expressed his doctrinal views with a minimum of elaboration." ${ }^{16}$ Thus, it is not always apparent what the shaykh intends to say. Moreover, he does not devote a single full and definitive work to theodicy. Instead, he deals with theodicean questions in fatwas, commentaries and refutations of widely varying length and completeness that, furthermore, approach the relevant issues from a number of different angles. In view of the spare and diffuse nature of Ibn Taymiyya's reflection on theodicy, I have ranged widely in the shaykh's corpus in search of applicable texts in order to provide a reasonably full picture of his thought on the subject.

In order to facilitate further discussion and reference, the remainder of this section describes Ibn Taymiyya's major theodicean texts located for this study. The texts are dated where possible. Numerous shorter writings and passages in larger works beyond those listed here will be introduced briefly as they are employed in later chapters or cited only in the notes. The following section of this Introduction attends to the methodological issues involved in reconstructing the shaykh's theodicy from these respective texts. ${ }^{17}$

Michot, Ibn Taymiyya: Lettre à un roi croisé (Al-Risâlat al-Qubrusiyya) (Louvain-la-Neuve: Bruylant-Academia, 1995); and in Abdul Hakim I. al-Matroudi, The Hanbali School of Law and Ibn Taymiyyah: Conflict or Conciliation (London: Routledge, 2006), 13-30. Donald P. Little explores the possibility of analyzing Ibn Taymiyya's psychology in "Did Ibn Taymiyya have a Screw Loose?” Studia Islamica 41 (1975): 93-111; and Yahya Michot seeks to explain Ibn Taymiyya's life-long celibacy in "Un célibataire endurci et sa maman: Ibn Taymiyya (m. 728/1328) et les femmes," Acta Orientalia Belgica 15 (2001): 165-190. Caterina Bori, "Ibn Taymiyya wa-jamā'atu-hu: Authority, Conflict and Consensus in Ibn Taymiyya's Milieu," forthcoming in Ibn Taymiyya and His Times, ed. Shahab Ahmed and Yossef Rapoport (Karachi: Oxford University Press, 2007), provides valuable insight into the shaykh's relations with his contemporary colleagues and followers. Bori also quotes statements by Ibn Taymiyya's contemporaries that corroborate aspects of my characterization of the shaykh's theological method described below in Chapter One. I am grateful to the author for sharing this article with me prior to publication.

16 Perho, "Man Chooses his Destiny," 63. A.S. Tritton in Muslim Theology (London: Luzac, 1947), 203, speaks of Ibn Taymiyya's style less sympathetically, stating, "He was not a clear thinker."

${ }_{17}$ Shahab Ahmed faces a similar set of methodological issues when examining Ibn Taymiyya's scattered statements on the Satanic verses in "Ibn Taymiyyah and the Satanic verses," Studia Islamica 87 (1998): 67-124 (especially the comments on 74). Ahmed's combination of translation, exposition and analysis provides a model of how these methodological difficulties may be overcome in order to make Ibn Taymiyya's views accessible. 
Texts relevant to this study have been identified in three ways. ${ }^{18}$ Employed first were major texts identified in the secondary literature as touching on theodicy and related issues, most notably Minhäj al-sunna al-nabawiyya [hereafter Minhäj], Iräda and Abü Dharr, which are described below. Second, the most comprehensive printed collection of the shaykh's writings, the thirty-seven volume Majmü fatāwā [hereafter MF], was examined. Especially Volume Eight devoted to divine determination (qadar) and the matching index on qadar in Volume Thirty-Six turned up many texts and passages that have not been used in previous research. ${ }^{19}$ These include the treatises Tadmuriyya, Kasb, Jabr, Hasana and Fätiḩa described below. Third, a few more items of interest were found by consulting the tables of contents in many of the books and collections not found in MF. The treatise 'Ádil, which will be noted below, was identified in this way. No search was made among manuscripts because it appears that most of Ibn Taymiyya's extant works have been published. ${ }^{20}$ However, there are some apparently lost works that

${ }_{18}$ This study cites works by Ibn Taymiyya with short titles (e.g. Iräda, Nubuwwāt, Dar’) whose full references are located in the Bibliography under "Ibn Taymiyya's Writings." The full references of collections usually cited only by their abbreviations (e.g. MF, MRM, MRK) are also found there. Very short texts have not been given short titles and are cited only by their locations in the respective collections. No attempt has been made to undertake the enormous text critical task that awaits the field of Ibn Taymiyya studies, but I have tried to use the best editions available to me. I employ the older and reasonably widespread Majmin fatāwa [abbreviated MF] (several publishers) in 37 volumes as opposed to the newer, but not superior, Majmü at al-fatāwa in 20 volumes. The contents of the two collections are identical, but the pagination unfortunately differs. Collections and re-editions of Ibn Taymiyya's works abound, but they often simply repackage-sometimes carelessly and usually without acknowledgement-various portions of MF. Thus, I make every effort to employ MF as the standard basis for citation. Many of Ibn Taymiyya's works-especially his larger ones—are not found in MF. One requires special note. Minhäj, the fine critical edition of Ibn Taymiyya's Minhajj al-sunna al-nabawiyya, is not yet widely available in libraries or in the marketplace, whereas the old Būlāq edition (short title MinhäjB) has been used almost universally for previous research. Thus, volume and page citations to Minhajj in the notes are followed by a slash and the equivalent volume and page reference in the old Būlāq edition in order to facilitate cross checking. Unfortunately, I have not had access to what Aron Zysow informs me is a promising new series of critical editions of Ibn Taymiyya's writings: Äthär Shaykh al-Islām Ibn Taymiyya wa mà lahiqahā min àmāl (Makkah al-Mukarramah: Dār 'Ālam alFawāid, 1422-/2002-), which has reached 12 volumes as of this writing.

19 The index on qadar is found in MF 36:142-153.

20 An important listing of Ibn Taymiyya's extant works remains Carl Brockelmann, Geschichte der arabischen Litteratur, revised ed. (Leiden: E.J. Brill 1949), 2:125-7, with Supplement (Leiden: E.J. Brill, 1938), 2:119-126. An Arabic translation of Brockelmann's revised edition of Geschichte der arabischen Litteratur and the Supplement combined is found in Tärīkh al-adab al-'arabī, trans. Mahmūd Fahmī Hijāzīi (Cairo: Al-Hay'a al-mișriyya al-āmma li-l-kitāb, 1995), 6:402-420. Brockelmann's listing in English with many additions is found in Qamaruddin Khan, The Political Thought of Ibn Taymiyya (India: Adam, 1988), 186-198. Taking Brockelmann and Khan as rough guides, as well as indications in other 
would probably have been of interest to this study, especially Ibn Taymiyya's commentaries on the Muhassal and Arba'in of the Ash'arī Kalām theologian Fakhr al-Dīn al-Rāzì (d. 606/1209). ${ }^{21}$ Apart from these lacunae, the body of texts identified should constitute a sufficiently large and representative sample upon which to base this inquiry into Ibn Taymiyya's theodicy.

Much of the first and third volumes of the nine volume critical edition of Ibn Taymiyya's Minhāj deals with theodicean issues. Minhāj is a refutation of Minhāj al-karāma, a tract of anti-Sunnī polemic composed by 'Allāma Ibn al-Muțahhar al-Hillì (d. 726/1325), a Twelver Shīî scholar who lived in the Mongol Îlkhānid Empire of Iraq and Persia that rivaled the Mamlūk sultanate. The İlkhānid ruler Oljeitu (d. 716/1316) converted from Sunnism to Twelver Shîissm in 709/1310, possibly through al-Hillī’s efforts, and al-Hillī wrote Minhäj al-karäma at the ruler's behest sometime thereafter. ${ }^{22}$ The date of Minhäj, Ibn Taymiyya's response, is no earlier than 713/1313 because it includes several mentions of Dar' ta' ärud al-'aql wa al-naql [hereafter $\left.D_{a r}{ }^{\prime}\right]$, a tome which its editor Muhammad Rashād Sālim has dated to

secondary literature (e.g. Laoust, "Ibn Taymiyya," EI2 3:953), it appears that most of Ibn Taymiyya's extant works have been printed. Additionally, many available printed works have been collected onto a CD ROM produced in Jordan: Mu'allafät al-shaykh wa tilmidhihi Ibn al-Qayyim, CD ROM, Version 1.0 (Amman: Markaz al-turāth li-abḥāth al-hāsib al-ālī, 1420/1999). Except as a guide to what is in print, this CD ROM is unfortunately of limited use because the introductions and scholarly apparatus of the sources have not been included. A number of treatises are in fact found on this CD ROM in more than one place, but there is no cross referencing system to make this readily apparent.

${ }^{21}$ Fakhr al-Dīn Muhammad b. 'Umar al-Khațīb al-Rāzī, Muhașsal afkār al-mutaqaddiminn wa al-muta'akhkhirin min al-'ulam $\vec{a}$ wa al-hukam $\vec{a}$ wa al-mutakallimin, ed. TTāhā 'Abd al-Ra'ūf Sa'd (Cairo: Maktabat al-kulliyyāt al-azhariyya, n.d.); and Fakhr al-Dīn al-Rāzī, $A l$ Arba' in fì ușül al-dìn, ed. Aḥmad Hijāzī al-Saqā (Cairo: Maktabat al-kulliyyāt al-azhariyya, n.d.). Ibn Taymiyya himself mentions that he wrote books on Muhassal and Arba' in in Qudra, MF 8:7. Ibn Qayyim al-Jawziyya (or rather, Ibn Rushayyiq), Asmä mu'allafät Ibn Taymiyya, 19, says that Ibn Taymiyya's work on Muhassal is one volume and the work on Arba' in is two volumes. These two works are also noted by Ibn 'Abd al-Hādī, $A l{ }^{\prime}{ }^{\prime} U q \bar{u} d$ al-durriyya, 37; Ibn Rajab, Kitāb al-dhayl, 2:403; al-Ṣafadī, Kitäb al-wäfî̀ bi-l-wafayāt, 7:24; and al-Kutubī, Fawāt al-wafayyät, 1:76. Brockelmann does not mention these two commentaries, and I have not seen any note of them elsewhere in the literature.

${ }^{22}$ I cite Minhāj al-karāma as it is found in Ibn Taymiyya's Minhäj. For an overview of this work, see Henri Laoust, "La critique du Sunnisme dans la doctrine d'Al-Hillì," Revue des études islamiques 34 (1966): 35-60. For manuscripts of Minhäj al-karäma, see Sabine Schmidtke, The Theology of al-'Alläma al-Hillì (d. 726/1325) (Berlin: Klaus Schwarz, 1991), 95. On alHillī’s relationship to Oljeitu, see Muhammad Rashād Sālim, Minhāj A, Introduction 1:16, 23; Schmidtke, Theology, 23-31; and Moojan Momen, An Introduction to Shici Islam: The History and Doctrines of Twelver Shi ism (New Haven, CT: Yale University Press, 1985), 92. Oljeitu is also known by his Muslim name, Khudābanda. 
sometime between $713 / 1313$ and $717 / 1317 .{ }^{23}$ Given the great size of both Dar' and Minhäj, it is likely that Minhäj was written well after 713/1313. Laoust speculates that it might have arisen from Ibn Taymiyya's involvement in a conflict over Shîi policy in Mecca in $716 / 1317 .^{24}$

Among the many domains in which al-Hillī takes Sunnīs to task in Minhäj al-karama is theodicy. Drawing on the Mu'tazili polemical tradition that had permeated Shīī theology, he imputes Ash'arī voluntarism to all Sunnīs and attacks this doctrine of God with numerous problems of moral evil. ${ }^{25}$

${ }^{23}$ In the introduction to the earlier incomplete critical edition MinhäjA, 1:16, Muhammad Rashād Sālim notes that Minhäj mentions Dar' several times. He also dates Dar' and the subsequent Minhäj to as early as 710 AH. However, Sālim renders this date impossible in his introduction to $D a r^{\prime}, 1: 7-10$, which was published later. There he cites the report of Ibn 'Abd al-Hādī, Al-'Uqüd al-durriyya, 26, that Ibn Taymiyya wrote a volume answering a certain Kamāl al-Dīn b. Sharīsīs response to Dar'. Sālim reasons that Ibn Taymiyya wrote Dar' no later than 717 AH because Ibn Sharīsī would have needed a bit of time to read Dar' and write his response before his death in 718 AH. Sälim concludes that Ibn Taymiyya must have written Dar' after returning to Syria in $712 \mathrm{AH}$ based on the fact that he once mentions his sojourn in Egypt in the past tense. Sălim adds that it is more likely that Ibn Taymiyya wrote this long work during his later and calmer Syrian period than during his tumultuous life in Egypt. Ibn Taymiyya mentions having been in Egypt in Dar', 1:25. Also, several of Ibn Taymiyya's major works can be safely dated later than $713 / 1313$ because they contain references to Dar'. These include Mantiqiyyin, Jawäb, Awliyä and Nubuwwät (see Sālim in the Introduction to Dar', 1:6). Tarif Khalidi gives Dar' the flattering remark that it "will undoubtedly become a philosophical classic" in Arabic historical thought in the classical period (Cambridge, UK: Cambridge University Press, 1994), 215 n. 65. Yahya Michot, "Vanités intellectuelles... L'impasse des rationalismes selon le Rejet de la contradiction d'Ibn Taymiyyah," Oriente Moderno 19 (2000): 597-617, states with respect to Dar', "The quantity alone of [Ibn Taymiyya's] references [to the philosophical tradition] already allow him to be considered as the most important reader of the faläsifah after Fakhr al-Dīn al-Ràzī in the Sunni world" (599). In this article, Michot translates Dar', 1:156-170, as an illustration of the sophisticated and interdisciplinary nature of Ibn Taymiyya's grasp of the Islamic intellectual tradition. Dar' has been published previously in part as Bayān muwäfaqat șarīh al-máqūl li-șahīh al-manqül (Clarification of the Agreement of Clear Reason with Correct Revealed Tradition) on the margin of Ibn Taymiyya, Minhäj al-sunna al-nabawiyya fì naqd kaläm alShï a wa al-Qadariyya [MinhäjB], 4 vols. (Beirut: Dār al-kutub al-ilmiyya, n.d.), reprint of 1321/1903-4 Cairo (Būlāq) edition. This edition corresponds to Dar', 1:3-4:295.

${ }^{24}$ Laoust, "Ibn Taymiyya," EI2 3:952. In his earlier "La biographie," 155, Laoust asserts that Minhäj could have been written no earlier than 1321 because the work to which it responds, the Minhäj al-Karama of al-Hillī, was only written in 1321. This is impossible because al-Hillī wrote Minhāj al-Karāma for Oljeitu (i.e. Khudābanda) who had died five years earlier in $716 / 1316$.

${ }^{25}$ On al-Hilli’'s Mu'tazilism in theology, especially his view that God does the best (aslab) in both religious and worldly matters and his notion of God's compensation, see Schmidtke, Theology, 109-116, and 117-124. See also the theological treatise, Hasan b. Yûsuf b. 'Alī ibnu 'l-Muțahhar al-Hillīi, Al-Bâb 'l-Hâdî' Ashar: A Treatise on the Principles of Shî̀ ite Theology with Commentary by Miqdâd-l-Fâdil al-Hillī, trans., William McElwee Miller (London: The Royal Asiatic Society, 1928). In Minhäj al-karäma, al-Hillì sums up his moral charges against Sunnism as follows, "Most of the [Sunnis] hold the doctrine that God-He is Mighty and Great—does bad deeds and that all kinds of disobedient acts, unbelief and corruption 
For example, he charges that this God is unjust because He determines that some should not believe, does not create in them the power to believe, and then punishes them for not believing. ${ }^{26}$ Also, this God is foolish because He commands unbelievers to believe but does not will that they believe. ${ }^{27}$ Unbelievers are actually obeying God because they are doing what God wills. ${ }^{28}$ Moreover, since the voluntarist Sunnī God does not act rationally for a purpose, He may even chastise the Prophet for obeying Him and reward Iblis for disobeying Him. ${ }^{29}$

Ibn Taymiyya's line-by-line refutation of al-Hillì's attack is rambling and repetitious, but the dominant strands of thought consistently follow the lines of a best-of-all-possible-worlds theodicy in which human accountability is somehow compatible with God's determination of all things. First, the shaykh affirms that God acts on account of wise purposes, and he deals at length in Volume One of Minhäj with the peculiar problems of necessity and imperfection that subjection to rational purpose poses for God's selfsufficiency and freedom. Here he affirms that God has been perpetually creating for wise purposes from eternity. Second, and especially in Volume Three, Ibn Taymiyya distinguishes God's will to create from God's will of command, and he explains that God has a wise purpose in willing to create some things that He prohibits. Third, the shaykh resists the charge that determinism obliterates human accountability. Human beings are the agents of their acts and therefore responsible for them even though God creates them. The details of these three lines of argument will be discussed below in Chapters Two, Three and Four, respectively.

The lengthy fatwa Iräda responds to an inquiry on whether the goodness of God's will implies that $\mathrm{He}$ creates for a cause. Ibn Taymiyya opens the fatwa with a typology of views on causality and wise purpose in God's will, but only at the end does he defend God's rationality against the Ash'arī objection that this implies need in God. In the intervening pages, he presents a typology of ways that evil (sharr) is attributed so as not to attribute it directly to God, an account of errors in divine creation and command,

occur by God's decree and determination. And that the human has no efficacy in that. And that God has no purpose in His acts, and that He does not do anything for the benefit of servants. And that $\mathrm{He}$ wills acts of disobedience from the unbeliever and does not will obedience from him. This makes hideous things follow necessarily," (as quoted in Minhäj, $3: 7-8 / 1: 264-5)$.

26 Al-Hillī, Minhāj al-karāma, as quoted in Minhāj, 3:20/1:267.

27 Al-Ḧillì, Minhäj al-karāma, as quoted in Minhäj, 3:179/2:34.

28 Al-Ḧillī, Minhāj al-karāma, as quoted in Minhāj, 3:154/2:28.

29 Al-Ḥillī, Minhäj al-karäma, as quoted in Minhäj, 3:86/2:11. 
and a discussion of human agency that includes considerations of secondary causality. ${ }^{30}$ The opening lines of Iräda, apparently added by a copyist, tell us that Ibn Taymiyya received the request for this fatwa from Egypt in Shawwāl 714/January-February 1315. Presumably, the shaykh responded from Damascus soon thereafter. ${ }^{31}$

Ibn Taymiyya's Tadmuriyya creed is perhaps one of the shaykh's most systematic, although not complete, presentations of doctrine. ${ }^{32}$ The first part deals with God's attributes while the second takes up God's relationship to the world. Among other things, this latter part discusses secondary causality and God's creation and command, and it sets out typologies of error on both questions.

Two medium-length fatwas deal with the apparent incompatibility of human accountability and divine compulsion ( jabr). In Kasb the inquirer asks whether humans have any efficacy $\left(t a^{\prime} t h i r\right)$ in bringing their acts into existence. The questioner argues that if someone does have efficacy then he becomes an associate with the Creator in the creation of his act. This threatens the exclusivity of God's creation. Conversely, if the human has no efficacy, this leads to divine compulsion, and there is no longer any basis for human accountability to the Law. The inquirer closes by asking for clarification that will "release minds from this bond and heal hearts of this distressing disease." ${ }^{33}$ The questioner in the second fatwa Jabr asks in poetic verse, "How is it that the servant chooses his acts, and the servant in acts is compelled?" The inquirer infers that one who is compelled is forced and such a person is excused. He ends by noting that he became ill with longing to come to see Ibn Taymiyya, but divine determinations (maqādir) had prevented him. ${ }^{34} \mathrm{Jabr}$ opens with a lengthy treatment of doctrine and error in God's creation and God's command. Then, in both Kasb and Jabr, Ibn Taymiyya

30 Irāda, MF 8:81-158.

31 This information is found only at the beginning of the versions of Iräda found in MRM 5:113-70 and MRK 1:318-86. For some reason the editors of MF did not see fit to include it.

32 Tadmuriyya, MF 3:1-128. Ibn Taymiyya also tells us on the first page that he wrote this treatise in response to a request for the contents of one of his teaching sessions. Henri Laoust, La profession de foi d'Ibn Taymiyya: Texte, traduction et commentaire de la Wāsitiyya (Paris: Librairie Orientaliste Paul Geuthner, 1986), 38-9, n. 4, calls this creed Ibn Taymiyya's most methodological presentation of doctrine.

33 Kasb, MF 8:386-405 (inquiry on 386).

$34 \mathrm{Jabr}, \mathrm{MF}$ 8:448-515 (inquiry on 448-9). Reading asqamani (MFCD) in the last line of the poem instead of the indecipherable $s-y-q-m-n$ (MF). In a third fatwa of this kind, Tä iyya, MF 8:245-255, the inquirer, identified as a scholar of the non-Muslim protected peoples (dhimmis), wonders whether he is disobedient when the Lord has willed his unbelief. To this Ibn Taymiyya himself replies in poetic verse. 
attempts to maintain the compatibility of God's determination (qadar) and human agency-focusing especially on the dynamics of secondary causality in Kasb-in order to retain human accountability. He explains that God has a wise purpose in the creation of all things, and, towards the ends of both fatwas, he gives brief typologies of the ways evil is attributed. Jabr also includes a typology of views on definitions of God's justice.

Two major treatises deal extensively with God's justice ('adl). Abū Dharr is a commentary on the divine saying ( $h a d i t h ~ q u d s i$ ) found in the hadith collection of Muslim, "O My servants! I have forbidden injustice to Myself." 35 At issue in the early part of this treatise is the conflict between God's freedom afforded by voluntarism and the necessary obligation on God imposed by rational justice. Ibn Taymiyya seeks to avoid these two extremes by interpreting this hadith to mean that God's justice is self-imposed rather than imposed by the necessity of independent reason. ${ }^{36}$ The treatise 'Adil gives two successive typologies of positions on God's justice and then presents a discussion of evil and God's punishment of bad deeds that focuses on the goodness of all that God creates. The treatise ends with a brief discussion and affirmation of al-Ghazālī's claim that this is the best of all possible worlds. ${ }^{37}$ The heading of ' $\bar{A} d i l$, apparently added by an early copyist, notes that this treatise is "among the things [Ibn Taymiyya] composed in his final detention in the citadel in Damascus." ${ }^{38}$ This dates it to the last two years of his life, sometime between 726/1326 and 728/1328.

Hasana, an exegetical work on Q. 4:78-9 taking up nearly 200 pages in the printed edition, includes one of Ibn Taymiyyas longest discussions of the problem of evil as he tries to resolve the contradiction between "Everything

35 Muslim, 4674, Al-Birr wa al-ṣila wa al-ādāb, Tahrīm al-ẓulm. Additional locations of this hadith are mentioned in William A. Graham, Divine Word and Prophetic Word in Early Islam (The Hague: Mouton, 1977), 205-6. Due to the many different hadith collections on the market, hadith reports are cited in this study only by the name of the collector (Bukhārī, Muslim, Ibn Māja, etc.) Hadith numbering follows the system of the 'Ālamiyya company (tarqim al-älamiyya) used on the CD-ROM, Mawsü' at al-hadith al-shariff, Version 2.0 (Cairo: Sakhr, 1997). To enable location of references in hadith collections not following this numbering system, the "Kitāb" and "Bāb" are given for the first collection (usually Bukhārī or Muslim) in which the hadith has been found. Occasionally, I give the "Kitāb" and "Bāb" for a second collection if the hadith related by Ibn Taymiyya is not found in the first collection in its entirety. Translations of hadith reports are my own. In the many cases where there are differences (usually slight) between the way a hadith appears in an authoritative collection and in Ibn Taymiyya's writings, I follow Ibn Taymiyya's text. It is beyond the scope of this study to note and trace textual variations in hadith reports.

36 Abü Dharr, MF 18:136-209.

37 'A $A d i l$, JR 121-142.

38 'Ádil, JR 121. 
is from God" (Q. 4:78) and "Any evil thing that comes to you is from yourself" (Q. 4:79). How can everything be from God if some things, namely, evil things, come from the individual himself? Ibn Taymiyya explains that everything God creates is good on account of His wise purpose, and he attempts to resolve the contradiction by locating the cause of evil in nonexistence ('adam) and the failure of humans to do that for which they were created. The latter part of Hasana builds on this interpretation by arguing that none should be worshipped but God and that intercession should be sought only from whomever God authorizes because God does no evil and He is the sole source of good. ${ }^{39}$

Fatiha, a commentary on the first sura of the Qur'an, discusses the worship ('ibäda) and asking for help (isti'äna) that derive from this sura's fifth verse, "You alone we worship, and You alone we ask for help." It also explores various metaphysical and ethical aspects of the relationship between God and His servants who were created to worship Him. ${ }^{40}$ As in Hasana, this text attributes the cause of evil ultimately to nonexistence. The comparatively formal character of Fätiha's presentation of evil and its other contents suggests that it comes from late in Ibn Taymiyya's life.

\section{Method of Analysis and Presentation}

A diachronic analysis of the major theodicean texts described above might provide clues to evolution in Ibn Taymiyya's thought. It would especially clarify whether his use of the Avicennan concept of evil as nonexistence in Hasana and Fätiba, but not in other texts, was a later development or just an irregularity of habit. These kinds of questions can only be answered with certainty on the basis of a chronology of the relevant texts. However, most of the major treatises do not indicate their dates, and they do not mention other dateable works that would set a terminus a quo. ${ }^{41} \mathrm{I}$ also have not found

39 Hasana, MF 14:229-425. An unnamed fatwa in MF 8:204-234 abridges Hasana, MF 14:294-361. Only the opening paragraph giving the inquiry and the final paragraph of the fatwa are not found in Hasana.

40 Fätiha, MF 14:4-36.

41 Ibn Taymiyya does mention Mahabba and an unidentifiable Qāंida kabìra in Fätiḩa, MF 14:14 and 27, respectively. Mahabba itself contains no mention of datable works and cannot therefore be dated. Ibn Taymiyya occasionally indicates that he has dealt with something in another place, but this is a common feature in his writing that does not give significant information. 
external evidence by which to date the remaining treatises. Moreover, even if the major theodicean treatises could be set into chronological sequence, there would remain the problem of integrating numerous shorter and dateless writings into the scheme.

Since reliable diachronic analysis of these texts is not possible, some kind of synchronic analysis must be employed. A rigorously empirical methodology might urge that at least the major theodicean treatises described above receive separate exposition and analysis. While a text-by-text analysis would respect the unique character of each treatise, it would entail extensive repetition of similar ideas in scattered parts of the presentation and make the present work unwieldy. Even though the major theodicean texts described above have diverse points of departure, they usually broach several of the same theodicean issues and employ fairly consistent patterns of response. Ibn Taymiyya, for example, sets out similar three-fold typologies of views on God's justice in 'A $\bar{d}$ dil, Jabr and $A b \bar{u}$ Dharr. ${ }^{42}$ Two of the views on justice-the Ash' 'arī' and his own-are contrasted in similar analyses in Minhäj ${ }^{43}$ and in his major work on prophecy Nubuwwät. ${ }^{44}$ In another example, the shaykh presents a consistent three-fold typology on the attribution of evil in nine different places including Iräda, Kasb, Jabr, Fätih a, Hasana and Minhäj..$^{45}$

This repetition of certain basic issues suggests a thematic presentation in which the material relevant to a particular idea or question is discussed in one place, drawing from both the major theodicean texts and from other shorter and scattered passages. This also permits direct comparison of differing responses to similar questions. A thematic presentation, however, necessarily obscures the unique character of each text. Occasional translation and the brief descriptions of the major texts given above compensate for this to some degree. A thematic presentation also risks imposing more coherence and consistency on the texts than they rightly bear. I try to mitigate these difficulties by pointing out inconsistencies where they occur. When diversity warrants, I also treat passages relevant to a particular question in succession instead of synthesizing them into one account.

The major questions related to theodicy are covered in Chapters Two through Six. Chapter Two deals with Ibn Taymiyya's response to Ash'arī

\footnotetext{
'Ádil, JR 121-6,126-130; Jabr, MF 8:505-510; and Abü Dharr, MF 18:137-156.

3 Minhäj, 1:134-141/1:33-4, 1:451-4/1:125-6, 2:304-313/214-5, 3:20-3/267-8.

${ }^{44}$ Nubuwwät, 143-7.

${ }^{4}$ Iräda, MF 8:93-7; Kasb, MF 8:400-1; Tã̄a, MF 8:446-7; Jabr, MF 8:511-2; Fätiha, MF 14:21; Hasana, MF 14:265-6; Thulth, MF 17:94-6, 99; Minhäj, 3:142-5/2:25-6; and Minhäj, 5:408-411/3:102.
} 
challenges to wise purpose in God's will. I begin with this issue for two reasons. First, establishing the very possibility of God's rationality is key for theodicy in Ibn Taymiyya's intellectual milieu of strong Ash'arī voluntarism. Second, the shaykh himself devotes considerable attention to this issue very early in his major work Minhāj, and this is the question that prompts his important fatwa Iräda. The remaining four chapters examine major clusters of ideas and rational difficulties in the relationship between God and humankind. Chapter Three surveys the varied terminology with which Ibn Taymiyya discusses God's creation and God's command and his suggestions as to the wise purpose that might be involved when the two conflict. Chapter Four investigates how the shaykh seeks to maintain the compatibility of God's creation of human acts with human agency and accountability. This includes discussion of secondary causality. Chapter Five considers evil, looking especially at the ends for which God wills it and its sources in human agents and nonexistence. The last chapter examines Ibn Taymiyya's concept of God's justice, and it closes with his view that God creates the best of all possible worlds.

It remains to say a few words about the first chapter. In the course of preparing Chapters Two through Six, several things became apparent. First, worship and ethics hold a central place in Ibn Taymiyya's thought and certain related epistemological claims recur often: reason knows what is beneficial in ethics; the existence of God is known by both reason and the natural constitution ( fitra); the natural constitution knows that the proper human end is love and worship of God; and reason agrees with authoritative revealed tradition. At the very least, some attention to ethics seemed appropriate to assess the link, if any, between Ibn Taymiyya's views on the moral quality of human acts and the goodness of God's acts. Additionally, comments scattered in the theodicean writings on the rational and traditional bases for knowledge of God's attributes, as well as arguments as to what the perfection of God entailed in His attributes and acts, suggested that a peculiar theological method was at work in the shaykh's argumentation. However, these comments were too sparse within the theodicean writings themselves to draw any conclusions.

These considerations led me to look beyond Ibn Taymiyya's theodicean writings for material that might make sense of what I had found within them. The result is Chapter One, which introduces Ibn Taymiyya's ethics, religious epistemology and theological methodology. This chapter is based on a less thorough investigation of the potentially relevant texts than the following five chapters on issues pertaining to theodicy proper, and it is also more highly synthetic than later chapters in drawing from a sampling of the 
shaykh's works to exemplify a point. Nevertheless, Chapter One provides a plausible and reasonably well substantiated ethical and theological horizon against which to interpret Ibn Taymiyya's theodicy. It also leads me to observe that his approach to theological questions is that of a jurist seeking the correct way to speak about God. 
CHAPTER ONE

WORSHIP, RELIGIOUS EPISTEMOLOGY
AND THEOLOGICAL JURISPRUDENCE

Ibn Taymiyya as a Theological Jurist

There has been no comprehensive study of Ibn Taymiyyas theological methodology, and his attitude toward reason in theological matters has not been well understood. The Hanbali legal school to which Ibn Taymiyya belonged was of two minds in preceding generations concerning rational argument in theology. On one side were the likes of al-Barbahārī (d. 329/941) and Ibn Qudāma (d. 620/1223) who completely opposed discussion of theological matters and permitted no more than repeating what was said about God in the data of revelation. ${ }^{1}$ On the other side were Abū Yálā (d. 458/1066) and his disciple Ibn 'Aqiil (d. 513/1119) who produced writings dealing with the principles of religion (ușülal-dinn), which were in content and structure not unlike Kalām works of the Ash'arīs and Mu'tazilīs. ${ }^{2}$ Even though Ibn 'Aqīl

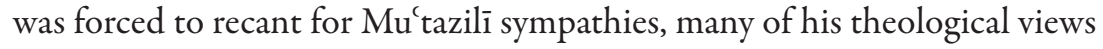
were adopted later by Ibn al-Jawzì $(597 / 1201) .^{3}$

Ibn Taymiyya is well known both for strict reliance on the Qur'an and the Sunna and for extensive polemic against Kalām theology, Aristotelian logic, Avicennan philosophy and the rationalizing mysticism of Ibn 'Arabī. Thus, he may well appear to belong to the first Hanbalī current, having no theological position of his own except unreflective adherence to the texts. This

${ }^{1}$ See Muwaffaq al-Dīn Ibn Qudāma al-Maqdisi, Tahrim al-nazar fì kutub al-kalām, ed. 'Abd al-Raḥmān b. Muḥammad Sa'ìd Dimashqiyya (Riyadh: Dār 'ālam al-kutub, 1990); translated into English by George Makdisi, Ibn Qudama's Censure of Speculative Theology (London: Luzac, 1962), in which Makdisi includes the Arabic text handwritten. For a general discussion of Hanbalī attitudes toward Kalām, see Bell, Love Theory, 49-54.

${ }^{2}$ See Abū Yà'lā Ibn al-Farrā', Kitāb al-mùtamad fì usūl al-dìn, ed. Wadi Z. Haddad (Beirut: Dar el-machreq, 1974); and George Makdisi, Ibn 'Aqïl: Religion and Culture in Classical Islam (Edinburgh: Edinburgh University Press, 1997), especially 85-9.

3 Merlin Swartz looks at the theological rationalism of Ibn al-Jawzī's later years in A Medieval Critique of Anthropomorphism: Ibn al-Jawzīs Kitāb Akhbār aș-Ṣifāt: A Critical Edition of the Arabic Text with Translation, Introduction and Notes (Leiden: Brill, 2002). In this regard, see also 'Abd al-Rahmān Ibn al-Jawzī, The Attributes of God (Daf' Shubah al-Tashbīh bi-Akaff al-Tanzīh), trans. ‘Ảbdullāh bin Hamīd 'Alī (Bristol, UK: Amal Press, 2006).

(c) Jon Hoover, 2007

This is an open access chapter distributed under the terms of the http://creativecommons.org/licenses/by-nc/3.0/. 
is indeed the way some have portrayed him. In the course of describing Ibn Taymiyya's polemical agenda, Ignaz Goldziher notes that the shaykh "relied on the sunna and on the sunna alone." More forcefully, Majid Fakhry uses the terms "slavish traditionalism," "antirationalist polemics" and "misology" in describing Ibn Taymiyya's place in the history of Islamic philosophy. ${ }^{5}$

This interpretation of Ibn Taymiyya is no longer sustainable. It is true that the shaykh vigorously maintains that all principles of religion have been revealed in the Qur'an and the Sunna. ${ }^{6}$ But an ardently anti-rationalist portrayal of Ibn Taymiyya fails to make sense of three other aspects of his writings. First, he frequently claims that knowledge derived from clear reason (al-'aql al-șarīh or al-șarīh al-máqül) agrees and corresponds with revealed tradition (naql or sam ), the message of the prophets and the way of the Salaf. ${ }^{7}$ Further on below, I examine the roles that Ibn Taymiyya gives reason and its dynamic equivalent the natural constitution ( fitra) in acquiring knowledge of ethical value, God's existence and God's attributes. This will show clearly that his religious epistemology gives a more prominent role to reason than his reputation would suggest. ${ }^{8}$

Second, Ibn Taymiyya explicitly permits rational theological argument in Khawd, a fatwa written while in Egypt (705-712/1306-1313) whose importance is underlined by its later inclusion near the beginning of $\mathrm{Dar}^{3}$.?

\footnotetext{
${ }^{4}$ Ignaz Goldziher, Introduction to Islamic Theology and Law, trans. Andras and Ruth Hamori (Princeton, NJ: Princeton University Press, 1981), 240.

${ }^{5}$ Majid Fakhry, A History of Islamic Philosophy, 2d ed. (New York, NY: Columbia University Press, 1983), 312-8. See also George Makdisi, "Ash'arī and the Ash'arites in Islamic Religious History," Studia Islamica 17 (1962): 37-80, and 18 (1963): 19-39, reprint as Part I in Makdisi, Religion, Law and Learning in Classical Islam, who includes Ibn Taymiyya in the camp of anti-rationalist traditionalism which he believes to have been the main theological current in medieval thought over against rationalist Ash'arism. Later, Makdisi, "Ethics in Islamic Traditionalist Doctrine," in Ethics in Islam, ed. Richard G. Hovannisian (Malibu, CA: Undena, 1985), 47-63, reprint as Part IV in Makdisi, Religion, Law and Learning in Classical Islam, softens his thoroughly anti-rationalist view of traditionalism somewhat by recounting a number of Ibn Taymiyyas theological arguments and positions.

${ }^{6}$ Dar', 1:27-8; Nubuwwāt, 58-9, 214-5; and Máārij, MF 19:155ff.

Nubuwwāt, 215, 239-240, 433; Jawāb, 4:395, 401; Istiqāma, 1:23; Minhāj, 1:3001/1:82; MF 5:172; MF 6:525; MF 6:580; MF 7:665; 'Abd al-Qädir, MF 10:475; MF 12:47; MF 12:80-1; MF 12:229; 'Alaq, MF 16:463; and 'Imrän, MF 18:240.

8 See Michot, "Vanités intellectuelles" 597-602, for further discussion of Ibn Taymiyya's unjustified reputation as antagonistic to philosophical thinking.

9 Khawd appears in truncated form in MF 3:293-326 and apparently full form in Dar', 1:25-78. References to Khawd hereafter will be made only to Dar'. At the point where he begins copying Khawd into Dar', Ibn Taymiyya notes that he wrote this fatwa in Egypt. In its intention to permit rational argument in theology, Ibn Taymiyya's Khawd compares to al-Ash'arī's Risāla fì istihsān al-khawd fì 'ilm al-kaläm found in Richard J. McCarthy, The Theology of al-Ash' ari (Beirut: Imprimerie Catholique, 1953), 85-97 (Arabic) and 117-134
} 
This text argues that it is not disliked (makrüh) to address people in their own terms as long as the proper meanings of words are ascertained. Hadith reports and the Qur'an may even be translated into other languages if necessary. In order to achieve clear communication one needs to know both the meanings of words used by the group addressed and the meanings of the terms used in the Qur'an and the Sunna. Also, Ibn Taymiyya explains, the Salaf did not reject Kalām terminology and argumentation as such. They were aware that God Himself had propounded rational arguments, and they were open to non-quranic terminology so long as it carried meanings congruent with revelation. What the Salaf reproached in Kalām theology was using terms in the wrong senses and misconstruing the role of rational arguments. ${ }^{10}$ In other words Kalām theology went astray not in using reason as such but in holding erroneous doctrines and using reason incorrectly.

Third, some of my own previous research has made apparent that the shaykh attacks Kalām theology and Avicennan philosophy not because he opposes reason but because he articulates and defends a fundamentally different vision of God. In two earlier studies, one on the shaykh's 'Imrān, a hadith commentary on the creation of the world, and the other on Ikbtiyariyya, a treatise on God's voluntary attributes, I provide evidence that Ibn Taymiyya views God in His perfection and very essence as active, creative, willing and speaking from eternity. Whereas both the Kalām theologians and the philosophers locate the perfection of God's essence in timeless eternity, Ibn Taymiyya locates it in personal and perpetual dynamism. ${ }^{11}$ Chapter Two

(trans.). However, al-Ash'arī does not draw Ibn Taymiyya’s distinction between analogical and a fortiori reasoning that will be explained below. Al-Ash'ari implicitly accepts the former in theology, whereas Ibn Taymiyya does not.

${ }^{10}$ Dar' $^{2} 1: 28,43-6$. For other discussions of Ibn Taymiyya's adoption of theological dialectic, see Bell, Love Theory, 54-5; and Thomas F. Michel, A Muslim Theologian's Response to Christianity: Ibn Taymiyya's Al-Jawab Al-Sabih (Delmar, NY: Caravan, 1984), 40-3. Bell and Michel both appear to be drawing on Khawd. However, I could not verify this because the printed editions they used were not available to me. Ibn Taymiyya also discusses translation of the Qur'an for the sake of non-Arabic speakers in Mantiq, MF 4:117, explaining that it may be necessary to give similitudes (amthäl) to convey the meaning and that this is in fact part of translation. In Bughya, 25, Ibn Taymiyya comments that one need only understand the technical terms of the philosophers to grasp their intentions. He adds that this is not only permissible but also good and sometimes obligatory.

${ }_{11}$ Jon Hoover, "Perpetual Creativity in the Perfection of God: Ibn Taymiyya's Hadith Commentary on God's Creation of this World," Journal of Islamic Studies 15:3 (Sept. 2004): 287-329, which translates 'Imrān, MF 18:210-243; and Jon Hoover, "God Acts by His Will and Power: Ibn Taymiyyas' Theology of a Personal God in his Treatise on the Voluntary Attributes," forthcoming in Ibn Taymiyya and His Times, ed. Shahab Ahmed and Yossef Rapoport (Karachi: Oxford University Press, 2007), which analyzes Ikbtiyäriyya, MF 6:217-267. 
below surveys material from Minhäj and Iräda that further confirms and elaborates this finding.

If Ibn Taymiyya is not an anti-rationalist polemist and unreflective literalist, what sort of theologian is he? Much work remains to be done on the shaykh's writings before this question may be answered adequately, but there are important preliminary indications. In a study on a portion of $D a r^{\prime}$ which treats Ibn Sīnās interpretation of prophetic imaginal discourse as a kind of pious fraud intended to motivate the intellectually inferior masses for their own benefit, Yahya Michot characterizes Ibn Taymiyya's hermeneutics as "literalist rationalism". ${ }^{12}$ Michot elaborates that Ibn Taymiyya rejects the hermeneutics of both the philosophers and the Kalām theologians in order to uphold "the self-sufficiency of the religious rationality manifested in scriptural literality and common faith, and its validity for all, the elite and the crowd." ${ }^{13}$ The nature of this egalitarian "literalist rationalism" becomes clearer in an article by Shahab Ahmed on God's protection ('isma) of the Prophets in Ibn Taymiyya's writings. Ahmed observes that the shaykh systematizes and reconstructs out of amorphous statements in the early authoritative sources what the Salaf apparently taught on the issue in question and explains "the rationale behind what they said, even if they did not say so themselves." ${ }^{14} \mathrm{My}$ studies on 'Imrän and Ikbtiyäriyya identify a similar dynamic. I note that in 'Imrän Ibn Taymiyya "seeks to elucidate the rationality underlying the data on creation found in the Qur'ān and the Hadith" such that his theology may be described as philosophical..$^{15}$ In my analysis of Ikbtiyäriyya, I call him an "apologist" seeking to elucidate and defend an "ordinary language" reading of the theological data of revealed tradition as rational and coherent. ${ }^{16}$

The present study of Ibn Taymiyya's theodicean writings provides further evidence confirming such characterizations of his intention. However, calling the shaykh an apologist or a philosophical theologian does not quite get to the root of what he is doing. Henri Laoust in his Essai suggests a different point of departure. Laoust explains that Ibn Taymiyya's theology is more of a moral theology than a theology devoted to knowing God in Himself (the traditional intention of Christian theology): "The doctrine of Ibn Taymiyya

12 Yahya J. Michot, "A Mamlūk Theologian's Commentary on Avicenna's Risäla Aḍ̂awiyya: Being a Translation of a Part of the Dar' al-Ta'a arud of Ibn Taymiyya, With Introduction, Annotation, and Appendices" [Trans. of Dar' 5:10-87], Journal of Islamic Studies 14 (2003): 149-203 (Part I) and 309-363 (Part II).

${ }_{13}$ Michot, "A Mamlūk Theologian's Commentary," 171.

14 Ahmed, "Ibn Taymiyyah and the Satanic verses," 112.

15 Hoover, "Perpetual Creativity," 295.

16 Hoover, "God Acts by His Will and Power," last paragraph of the article. 
comes in fact to an ethic. Despite the importance that he grants to theology, it is not the problem of knowledge of God which preoccupies him in the highest degree." ${ }^{17}$ Instead, Laoust explains, at the core of Ibn Taymiyya's thought is service ('ibäda) to God, which is grounded in quranic verses such as, "I did not create the jinn and humankind except that they might serve (ya'büd) Me" (Q. 51:56), and "There is no god but I; so serve Me" (Q. 20:14). The goal of the whole ethical, juridical and political life is to deepen this service to God. For Laoust, "It thus appears that Ibn Taymiyya's entire theology tends toward one sole aim: that of giving a foundation to his ethics, and consequently, to all his juridical and social philosophy." 18

While I will translate 'ibāda as "worship," Laoust reminds us with the translation "service" that the term in Ibn Taymiyya's discourse encompasses not only ritual practice but also matters ethical, juridical, social and political. The worship of 'ibada draws together all domains of life under the rubric of religious practice devoted solely to God. Laoust also insightfully links Ibn Taymiyya's theology to his ethics, but the idea that his theology aims to give a foundation to ethics or religious practice is open to more than one interpretation. It could mean no more than that theology constitutes the necessary ground for ethics insofar as theology speaks of the Creator God without whom creatures and their moral lives would cease to exist. Laoust seems to intend more, however, especially when he writes, "Ibn Taymiyya, who is a moralist and jurist more than a theologian, judges doctrines by their function and their value for action." ${ }^{19}$ In this light Ibn Taymiyya's theology becomes an instrumental and pragmatic effort to portray God in way that motivates worship and obedience to God.

There is some truth in what Laoust asserts. Ibn Taymiyya often concerns himself with the ethical implications of theological doctrines. This is especially apparent when he traces the sources of antinomian practices to extreme Ash'arī views on God's determination (qadar) and to Sufi notions of annihilation $(f a n \vec{a})$ and the oneness of existence (wabdat al-wujud ). Yet, it is not entirely clear that Ibn Taymiyya's interest in theology is strictly a function of its usefulness for inspiring human action. For example, 'Imrän, the shaykh's hadith commentary on the creation of the world mentioned above, is remarkably free of instrumentalized theology. Rather, Ibn Taymiyya's singleminded concern throughout is showing what reason and God's messengers

${ }_{17}$ Laoust, Essai, 177-8, 469-473 (quote on 469).

18 Laoust, Essai, 177.

19 Laoust, Essai, 158. 
indicate on the question of whether the world is eternal or created. The text defends and explains God's perpetual creation of things in this world, but it shows very little concern for ethical repercussions of this doctrine. ${ }^{20}$ A similar phenomenon is observable in Ikbtiyanriyya, the tract noted above that explicates the voluntary and perpetually active character of many of God's attributes. Ibn Taymiyya does introduce the ethical imperative to call on God and seek help from Him alone toward the end of this text, but this is incidental to, and not a logical inference from, the central argument of the treatise. ${ }^{21}$

Even with respect to texts like Ikbtiyariyya and 'Imrän, there remains an argument in Laoust's defense: Ibn Taymiyya crafts a vision of God as active, personal and much more intimately involved in temporal and human affairs than the God of Kalām theology and Avicennan philosophy in order to prompt more ready obedience to God's law. There is little doubt that part of the reason that Ibn Taymiyya took up his pen was to achieve such a goal. Nevertheless, without negating Laoust's thesis or the presence of pragmatic and instrumental elements in Ibn Taymiyya's theology, I propose that something more fundamental is driving his theological work. That is, the shaykh's theology is not subservient to its functionality in achieving ethical or political aims in the first instance. Rather, getting theological doctrine correct is an ethical and practical concern in its own right.

A passage translated by Fazlur Rahman and re-translated in part below provides the cue for this interpretation. Here Ibn Taymiyya draws into question the commonplace division in medieval Islamic thought between the principles $(u s \bar{u} l)$ which deal with creedal matters and the branches ( furür) which cover practical obligations and prohibitions. He prefers instead to set theological questions and matters of action firmly on the same level and regard both sets of issues as practical ('amali). From this perspective, knowledge of God's attributes is no different from knowledge of the practical duties of Islam such as the Five Pillars. Likewise, denying the practical duties is just as much unbelief as denying the theological doctrines.

Issues of [theological] information (al-masä il al-khabariyya) may be equivalent to practical issues (al-masä il al-'amaliyya) even though the former are called issues of the principles $(u s \bar{u} l)$ and the latter issues of the branches $\left(\right.$ furü $\bar{u}^{\prime}$.

20 Perhaps a minor exception may be seen in Ibn Taymiyya's explanation that God set aside one day each week for gathered worship as a sign pointing to the first week in which God created the world ('Imrän, MF 18:230-231).

21 Ibn Taymiyya begins treating this ethical issue at Ikhtiyāriyya, MF 6:258. See Hoover, "God Acts by His Will and Power," for further discussion. 
This designation [ușūl and fur $\bar{u}$ ] $]$ is made up; a group of jurists and Kalām theologians came up with this division.... The truth of the matter is that what is of great importance in each of the two types [informational and practical] are the issues of the principles and that the fine points are the issues of the branches. So, knowing the obligatory quality of obligations such as the five pillars of Islam and the forbidden nature of things forbidden manifestly and by abundant transmission is like knowing that God has power over everything and knows everything, that $\mathrm{He}$ is all-hearing and all-seeing, that the Qur'an is the speech of God, and such like from among manifest and abundantly transmitted propositions. Therefore, one who denies those practical rulings about which there is consensus disbelieves in the same way as one who denies these [theological doctrines] disbelieves. ${ }^{22}$

With the basic equivalence of doctrinal and practical questions in mind, worship ('ibadda) may now be seen to include not only ritual practice, ethics, jurisprudence and politics but also speaking correctly about God, which, as we will see by the end of this chapter, means speaking in a way that ascribes to God the highest perfection and praise. From this vantage point, Ibn Taymiyya's theological discourse is not most fundamentally an ideological instrument to motivate action or an attempt to know God in Himself but a practical search to find the most praiseworthy way to depict God. Put differently, thinking and speaking well of God is part of the law (shari $\left.{ }^{-} a\right)$, and the shaykh's theology is an attempt to spell out that aspect of the law. As such, it is an exercise in jurisprudence ( fiqh), and, even though I have not found Ibn Taymiyya speaking in precisely such terms, his theology is perhaps more appropriately called theological figh. Ibn Taymiyya may thus be seen as a theological jurist responding to inquiries and challenges concerning what should rightly be said about God. The apologetic and philosophical quality of this fiqh arises inasmuch as he deems it permissible, constructive or even necessary to take up rational reflection and argumentation in theological matters.

This chapter examines the methodology of Ibn Taymiyya's theological figh in greater detail, as well as key elements of his ethics and theology that will prove helpful for making sense of his theodicy. After first elaborating the role that Ibn Taymiyya gives to worship in his religious vision, this chapter turns to epistemological foundations for knowing that God exists and that $\mathrm{He}$ alone should be worshipped. It then examines how Ibn Taymiyya

${ }^{22}$ MF 6:56-7; translated in Rahman, Revival and Reform in Islam, 143. For further discussion of Ibn Taymiyya's dissolution of the widespread distinction between ușül and fur $\bar{u}$, see al-Matroudi, The Hanbali School, 69-72. 
delineates what should be said about God's attributes and acts so as to give God the highest praise.

\section{The Centrality of Worshipping God Alone}

An incident related by Ibn Taymiyya's biographer Ibn 'Abd al-Hādī (d. $744 / 1343$ ) points to the centrality of worship ('ibajda) in his vision of Islam. In the year 707/1307, on Friday, $30 \mathrm{Rabi}^{-\mathrm{c}}$ al-Awwal, Ibn Taymiyya went to a mosque in Cairo for the noon prayer. Some people asked him to teach, but he said nothing. He only smiled and looked around. Then someone quoted the quranic verse, "God made a covenant with those who were given the Scripture that you make it clear to the people and not conceal it" $(Q$. 3:187). At that, Ibn Taymiyya got up, quoted the first sura of the Qur'an, the Fātiha, and proceeded to speak on its fifth verse, "You alone we worship; You alone we ask for help," and the meaning of worship and asking for help (isti' āna) until the mid-afternoon ('aşr) prayer call, a period of perhaps two or three hours. ${ }^{23}$ Since Ibn 'Abd al-Hādì does not provide further details of Ibn Taymiyya's long discourse, we can only imagine what he might have said. However, there is ample material in his oeuvre to elucidate his thought on worship. ${ }^{24}$ The discussion here is limited to writings on the Fātiha itself.

For Ibn Taymiyya, the Fātiha holds a privileged place in the quranic revelation because God made its recitation a duty during what he considers the best of deeds, the ritual prayer (saläh). Furthermore, he sees the fifth verse "You alone we worship; You alone we ask for help" as both the summary of the Fātiha and the pivot between its two halves. "You alone we worship" ends the first half of the sura, which is worship dedicated to God. "You alone we ask for help" begins the half of the Fātiha, which is dedicated to the worshipper himself and in which he asks for the help that God will provide. In this fashion, the fifth verse captures the two elements of worship

\footnotetext{
${ }^{23}$ Ibn 'Abd al-Hādī, $A l$ ' Uqüd al-durriyya, 255.

${ }^{24}$ In addition to the sources from which the following discussion is drawn, see especially 'Ubūdiyya, MF 10:149-236; Qudra, MF 8:39-57; Tawhìd, MF 1:20-36; Shirk, MF 1:88-94; and the many selections pertaining to Ibn Taymiyyas spirituality in the two series of translations by Yahya M. Michot, "Textes Spirituels d'Ibn Taymiyya," Le Musulman (Paris), 11-29 (1990-8), and "Pages spirituelles d'Ibn Taymiyya," Action (Mauritius), 1999-2002. Full references for some of these may be found in the Bibliography, and, as of December 2006, the texts could be accessed at http://www.muslimphilosophy.com/it/index.html. Also of interest for Ibn Taymiyya's spirituality are Th. E. Homerin, "Ibn Taimìya's Al-Süfìyah wa-al-fuqaräa", Arabica 32 (1985): 219-244; and Thomas Michel, "Ibn Taymiyya's Sharh on the Futüh alghayb of 'Abd al-Qādir al-Jilānī”, Hamdard Islamicus, 4.2 (Summer 1981): 3-12.
} 
and supplication that characterize the whole sura. Here Ibn Taymiyya quotes a saying attributed to Hasan al-Bașri to the effect that God summarized all the scriptures in the Qur'an; then, He summarized the Qur'an in the Mother of the Book, the Fâtihạa; and finally He summarized the Fātiha in its two phrases, "You alone we serve, You alone we ask for help."25

Ibn Taymiyya also finds the senses of worship and asking for help grouped together elsewhere in the Qur'an and the Hadith just as they are in the Fātiha. He cites for example, "Worship Him, and trust completely in Him" (Q. 11:123), "In Him I have completely trusted, and to Him I turn" (Q. 11:88), and, "In Him I have completely trusted, and to Him is my repentance" (Q. 13:30). Turning to God (ināba) and going to God in repentance (tawba) are aspects of worship, and complete trust (tawakkul) is related to asking for help. In the hadith, "O Lord, this is from You and for You," ${ }^{26}$ Ibn Taymiyya interprets "for You (laka)" as worship and "from You (minka)" as complete trust and asking for help in the midst of whatever comes from God. ${ }^{27}$

In God's relationship with humanity, worship is linked to God's divinity (ulübiyya or ilähiyya) and asking for help to God's lordship (rubübiyya or rabbäniyya).$^{28}$ Ibn Taymiyya observes that these respective senses of divinity and lordship are found in the locutions of prayer. The name God (Alläh), which has the same Arabic root $(-l-b)$ as ulübiyya, is associated with worship, as in "God is greater (Allähu akbar)" and "Praise be to God (al-hamdu li-lläh)," while the name Lord (Rabb), which has the same root $(r-b-b)$ as rubübiyya, is linked with seeking help, as in "Our Lord, forgive us our sins" (Q. 3:147) and "Lord, forgive and be merciful; You are the best of the merciful” (Q. 23:118). ${ }^{29}$ Thus, as illustrated in the following quotation, worship flows out of God's divinity, and asking for help springs from His lordship.

["You alone we worship; You alone we ask for help" (Q. 1:5)] is the elaboration of His saying, "Praise be to God, Lord of the worlds" (Q 1:2). This indicates that there is no object of worship except God and that no one other than Him has the right to be worshipped. His statement, "You alone we worship," points to worship of Him by means of the love, fear, hope, command and prohibition

${ }^{25}$ Manbijī, MF 2:455-6; Talbis, 2:454; and Fätiba, MF 14:7.

${ }^{26}$ Dārimīi, 1864, Al-Aḍaḥ̄ị, Al-Sunna fî al-aḍhiyya.

${ }_{27}$ Manbiji, MF 2:456; and Fätiḩa, MF 14:9.

${ }^{28}$ Paralleling divinity and lordship in Ibn Taymiyya's writings is a wide range of cognate terms including God's command and creation and God's legislative will and ontological will, respectively, which will be discussed in detail in Chapter Three.

${ }_{29}$ Manbijī, MF 2:456; and Fätiba, MF 14:12-3. 
that His divinity requires, and, "You alone we ask for help," points to the complete trust, commitment, and submission that His lordship requires. ${ }^{30}$

For Ibn Taymiyya, asking for help signifies absolute human dependence on the God who is the Lord of the worlds. Lordship indicates God's creative and determining activity, and this lordship is exclusive. Creatures have absolutely no existence apart from God, and they may ask for help only from the source of their existence and trust in Him alone. The confession that God is the sole Creator and Lord of the universe is called tawbid alrubübiyya or tawhìd al-rabbäniyya. In like manner, worship indicates human devotion to God-turning to Him, loving Him, obeying Him, hoping in Him and fearing Him — and this is linked to God's divinity (ulübiyya). The divine is that which is loved and served as a god, and God's divinity denotes His essential right to worship. Tawbìd al-ulübiyya or tawhid al-ilähiyya is recognizing God as the only one with the right to divinity and turning to worship Him alone. This, as Ibn Taymiyya explains, is the meaning of the Islamic confession, "There is no god but God." Unifying all one's energies in worship to God excludes any kind of shirk or associating partners with God and withholding from God the devotion that only He deserves. ${ }^{31}$

Ibn Taymiyya clarifies the ultimate priority of God's divinity over God's lordship — and thus worship over asking for help—with the aid of Ibn Sinäs notions of final and efficient causality. Ibn Sinnā regards the final cause or telos (al-illa al-ghäizya) as the end for which something comes into existence, while the efficient cause (al-illa al-fấ iliyya) is that which brings the thing into existence. Furthermore, the final cause is an efficient cause in that it activates the operation of the efficient cause. Conversely, the final cause is also the effect ( $\left.m a^{\prime} l \bar{u} l\right)$ of the efficient cause when it is realized in existence. ${ }^{32} \mathrm{Ibn}$ Taymiyya applies this analysis to "You alone we worship; You alone we ask for help" by linking worship and divinity to final causality on the one hand and asking for help and lordship to efficient causality on the other:

The God (al-iläh) is the one worshipped (al-ma'büd) and asking for help is linked to His lordship. The Lord of the servants is He who lords over them. This entails that $\mathrm{He}$ is Creator of everything that is in them and from them. The divinity is the final cause, and lordship is the efficient cause. The final [cause] is that which is aimed at, and it is the efficient cause of the efficient cause. Therefore, He made "You alone we worship" precede "You alone we ask for help." Confessing the exclusiveness of the divinity (tawhid al-ilähiyya) includes

30 Shirk, MF 1:89.

31 Tawhìd, MF 1:22-3; and Manbijī, MF 2:456-9. Cf. Fì Fuṣūs, MF 2:404-6.

32 Ibn Sīnā, Al-Ishārāt, 3:30-3. 
confessing the exclusiveness of the lordship (tawhìd al-rubübiyya). Included in worshipping only God is not confessing the lordship of any other. ${ }^{33}$

This text subordinates lordship to divinity such that divinity is both the final cause, that is, the ultimate object of worship, and the efficient cause of confessing God's lordship, which in turn is the efficient cause bringing all things into existence. Exclusive worship of God includes confessing God as the sole Creator. In a different text, and as in the passage quoted above, Ibn Taymiyya observes that the Fātiha in "You alone we worship; You alone we ask for help" (Q. 1:5) puts the final cause of worship before the efficient cause of asking for help because the final cause should be the efficient cause of this efficient cause. Ideally speaking, worship activates and is the efficient cause of asking for help. Yet, Ibn Taymiyya observes, humans, out of their sense of profound neediness, typically confess God's lordship and ask for His help much more than they worship Him. Thus, God raised up messengers to focus on calling humanity to worship God alone. Then, when humans worship God, it will follow that they also confess His lordship and ask Him for help..$^{34}$ Putting it differently, God should be worshipped, loved, and praised primarily for Himself in His divinity and only secondarily for what He does in His lordship.

With the priority of worship in Ibn Taymiyya's thought firmly in view, we turn now to the epistemological foundations by which human beings know that God exists and should be their sole object of worship. Ibn Taymiyya bases his thought on quranic revelation, even if interpreting it philosophically, but he also makes the apologetic claim that independent reason agrees with revelation in providing the same information.

\section{The Correspondence of Reason and Revelation}

Ibn Taymiyya devotes his major work $D a r^{3}$, eleven volumes in the critical edition, to refutation of the rule established by Fakhr al-Dīn al-Rāzī and others that rational arguments must be given precedence over traditional proofs in case of contradiction. ${ }^{35}$ Instead, the shaykh contends, there is no contradiction between reason and tradition. Two studies by Binyamin Abrahamov illustrate that it is not immediately obvious what Ibn Taymiyya means by this. In a

33 Talbiss, 2:454. Cf. 'Ubüdiyya, MF 10:194.

34 Fätiha, MF 14:13-4

35 See especially Dar' $^{\prime}, 1: 4-8$. 
1992 article on Dar', Abrahamov notes that Ibn Taymiyya's view appears to come very close to that of the philosopher Ibn Rushd (d. 595/1198) in which revelation and reason are both true and do not contradict. ${ }^{36}$ Abrahamov concludes, however, that Ibn Taymiyya differs fundamentally from Ibn Rushd by confining himself to the terms and rational proofs found in the Qur'an and the Sunna. Reason does not disagree with revelation because it has no status apart from revelation. ${ }^{37}$

Later, Abrahamov explicitly rejects his former conclusion. In a 1998 general study of reason and revelation in Islamic theology, he briefly argues that for Ibn Taymiyya there are rational arguments arising from the human intellect independently of revelation, which are valid so long as they do not contradict revelation. Reason is thus an independent source for knowledge of God. Abrahamov does not present his case in detail, and he does not investigate the nature of the rational proofs in question, but what follows here supports his latter conclusion. ${ }^{38}$

Yahya Michot, in the introduction to his French translation of Ibn Taymiyya's letter to the Syrian prince Abū al-Fidā' (d. 732/1331), conceives the matter somewhat differently. Drawing upon $D a r^{\prime}$ and the letter to Abū al-Fidä', Michot explains that for Ibn Taymiyya the Qur'an and the Sunna are the summit and peak where the two paths of reason and tradition come together and from where they depart. Whatever contradicts the Qur'an and the Sunna lies outside the pale of rationality. Thus, the proofs of reason, rightly exercised, lead to the same end as do the proofs of tradition, and they derive from the same source..$^{39}$ A passage from Ibn Taymiyya's letter

${ }^{36}$ In an earlier article in Arabic, 'Abd al-Majīd al-Ṣaghīr elaborates similarities between Ibn Taymiyya and Ibn Rushd, "Mawāqif rushdiyya li-Taqī al-Dīn Ibn Taymiyya? Mulāhazāāt awwaliyya," in Dirāsāt maghribiyya muhdāt ilā al-mufakkir al-maghribì Muhammad 'Azìzz al-Habbäbì (Rabat: n.p., 1985), 93-117, 2d ed. (Rabat: n.p., 1987), 164-182.

${ }^{37}$ Binyamin Abrahamov, "Ibn Taymiyya on the Agreement of Reason with Tradition," The Muslim World 82:3-4 (July-Oct. 1992): 256-273. Coming to much the same conclusion are Nicholas Heer, "The Priority of Reason in the Interpretation of Scripture: Ibn Taymiyah and the Mutakallimūn," in Literary Heritage of Classical Islam: Arabic and Islamic Studies in Honor of James A. Bellamy, ed. Mustansir Mir (Princeton, NJ: The Darwin Press, 1993), 181-195; and Muhammad al-Sayyid al-Julaynad, Al-Imām Ibn Taymiyya wa mawqifubu min qadiyyat al-tàwīl (Cairo: Al-Hay'a al-'āmma li-shu'ūn al-mațābi' al-amīriyya, 1393/1973), 347-355.

${ }_{38}$ Binyamin Abrahamov, Islamic Theology: Traditionalism and Rationalism (Edinburgh: Edinburgh University Press, 1998), 51.

${ }^{39}$ Jean R. Michot, Ibn Taymiyya: Lettre à Abû l-Fid $\hat{a}$ (Louvain-la-Neuve: Institut Orientaliste de l'Université Catholique de Louvain, 1994), 18. Information on Abū al-Fidāà and the dating of the letter to the later years of Ibn Taymiyyas life is found on pp. 15-6. Laoust, Essai, 176-7, makes the same point less vividly: "The Law then is all reason. No opposition 
illustrates how revelation and reason may be conceived as complementary paths to the same truth.

[The Salaf and their followers] knew that both revelational and rational proofs were true and that they entailed one another. Whoever gave rational and certain proofs (al-adilla al-aqliyya al-yaqiniyya) the complete inquiry due them knew that they agreed with what the messengers informed about and that they proved to them the necessity of believing the messengers in what they informed about. Whoever gave revelational proofs (al-adilla al-sam'iyya) the understanding due them knew that God guided His servants in His Book to certain rational proofs by which are known the existence of the Creator, the subsistence of His attributes of perfection and His exoneration from imperfections and from anything being like Him in the attributes of perfection, and which prove His uniqueness, the uniqueness of His lordship, the uniqueness of His divinity, His power, His knowledge, His wisdom, His mercy, the truthfulness of His messengers, the obligation to obey them in what they obligate and command, and believing them in what they teach and inform about. ${ }^{40}$

According to this text, revelation reiterates the correct rational proofs pertinent to religion. As Ibn Taymiyya explains elsewhere, revelation contains both information (khabar) and rational proofs. The rational proofs are both revelational (shar $\bar{\imath})$ by virtue of being brought by God and His messengers and rational ( $\mathrm{C} q q \bar{l} \overline{\mathrm{i}}$ ) since they are judged true by reason. The shaykh also notes in the letter to Abū al-Fidāa and elsewhere that Kalām theologians, as well as philosophers-by whom he usually means the Aristotelian Neoplatonists al-Farābì (d. 339/950) and Ibn Sīnā-err when they confine revelation to the domain of information. ${ }^{41}$ To put the matter in another way, revelation embodies true rationality. Once one has access to revelation, one identifies it immediately as identical to whatever truth one knew previously through reason. In this vein, Ibn Taymiyya observes that the truthfulness of the

between revelation and reason should exist. The authentic scriptural tradition (naql sabīh) and proper reason ('aql sarīh) are two manifestations of the one and same reality."

40 "A Letter of Ibn Taymiyya to Abū l-Fidà,", ed. Serajul Haque, in Documenta Islamica Inedita, ed. Johann W. Fück, 155-161 (Berlin: Akademie-Verlag, 1952), 159. This Arabic text

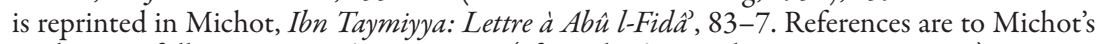
Arabic text following Haque's pagination (cf. Michot's French trans. on pp. 57-8).

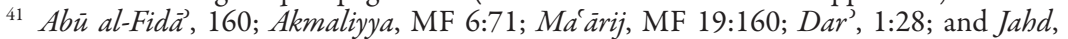
9:242/Manțiqiyyin, 382. Michel, A Muslim Theologian's Response to Christianity, 15, misguidedly argues that the term falassifa (philosophers) in Ibn Taymiyya's writings refers mainly to the Aristotelian Neoplatonists al-Farābī and Ibn Sinnā and occasionally also to Ibn Rushd and Naṣir al-Dīn al-Ṭūsī while the term mutafalsifa (pseudo-philosophers) is reserved for al-Suhrawārdī and the Ishrāqī school. Wael B. Hallaq, Ibn Taymiyya against the Greek Logicians (Oxford, UK: Clarendon Press, 1993), 4 n. 1, rightly explains that the terms faläsifa and mutafalsifa are in fact synonymous in referring to the wider philosophical tradition. The term mutafalsifa is not limited to the Ishrāqīs. 
prophets can be known only through reason. ${ }^{42}$ Conversely, the revelation immediately exposes irrational ideas for what they are. ${ }^{43}$

Ibn Taymiyya sets limits to what reason can know in theology and ethics. Revelation is required to know "the details of what [the prophets] informed concerning theological matters (al-umür al-ilähiyya), the angels, the Throne, Paradise, the Fire and the details of what is commanded and prohibited." 44 However, rational proofs, the best of which are found in the Qur'an, establish God's existence, God's attributes, and the obligation to believe and obey what God brings through His messengers.

\section{On Knowing that God Exists and that He Alone should be Worshipped}

\section{Reason and the Law}

Ibn Taymiyya reports that reason ('aql) has two meanings in the Islamic tradition. For Ahmad b. Hanbal it is a potency (quwwa) and an instinct (ghariza) by which one reasons. For others, including Kalām theologians, reason is a body of necessary knowledge (darb min al-ulüm al-darüriyya). Ibn Taymiyya says that both are true, and he compares 'aql to the word basar, which in Arabic may refer both to the faculty of sight and to the perception of seeing with this faculty. ${ }^{45}$

The shaykh explains that reason knows the foundational rules of thought: that like things are alike, that different things are different, and that two things cannot exist in the same place at the same time. For example, it is neither rational nor possible to combine black and white in one place at one time, and something cannot be simultaneously existent and nonexistent. ${ }^{46}$ Without acknowledging the sources of his ideas, Ibn Taymiyya also affirms that reason knows metaphysical notions relating to efficient causality that

${ }^{42}$ Abü al-Fidè, 160.

43 Michel, A Muslim Theologian's Response to Christianity, 129, makes much the same observation in discussing the epistemology of Ibn Taymiyya's refutation of Christianity in Jawäb al-Sahih: "[Ibn Taymiyya holds that] truth is unitary. Whatever has been truly revealed can never be contradicted by what is known through reason and sense perception, but can only be confirmed by such information. Similarly whatever is correctly known from intellectual knowledge or from accurate sense perception must be confirmed by revelation." As Michel notes, the shaykh also holds sense perception to be a valid source of knowledge.

${ }^{44}$ Furqān, MF 13:138.

45 Istiqäma, 2:161-2; and Bughya, 31-40, which gives a very detailed discussion of the meaning of 'aql.

${ }_{46}$ Qudra, MF 8:9; and Jawāb, 4:391, 396-7. 
are basic to Kalām theology and the philosophy of Ibn Sīnā. With Kalām theology, it is known by clear reason that an existent is either originated (mubdath) or eternal, either created or uncreated, and with Ibn Sinā, it is known by clear reason that an existent is either necessary in itself (wajjib $b i$-nafsibi) or not necessary by itself, either sufficient apart from another (ghani 'ammà siwähu) or in need of another. ${ }^{47}$

With these metaphysical oppositions in place, the shaykh sets forth simple and direct cosmological arguments for God's existence. The existence of the Creator is known necessarily by reason from the fact of created existence. It is commonsense that everything needs a cause and that all things must have an originator that is ultimately eternal and self-sufficient: "The originated being itself knows through clear reason that it has an originator." ${ }^{48}$ Every creature is by its very existence a sign necessarily entailing the essence, unity and attributes of the Creator, and it is the way of the prophets to point to God by mentioning these signs. ${ }^{49}$ The existence of the Self-Sufficient and the Eternal Existent which is Necessary in Itself is known by "the necessity of reason (darürat al-'aql)" and from the need of every originated event for an originator (mubdith), as well as from the need of something possible (mumkin) for something else to give it existence (müjid)..$^{50}$

Ibn Taymiyya contrasts his straight-forward proofs for God's existence from 'aql with the Kalām method of rational inference (nazar) which proves the existence of the Creator by indirect cosmological arguments appealing to the origination of accidents and the composition of bodies from atoms. ${ }^{51} \mathrm{He}$ criticizes especially the Mu'tazilīs and some Ash'arī and Hanbalī theologians for making nazar the initial human obligation. ${ }^{52} \mathrm{He}$ argues that this method, whose origins he traces to Jahm b. Șafwān (d. 128/745), is not a necessary basis for knowledge of God's existence. Speculation of this sort leads to

${ }^{47}$ Minhāj, 2:116/1:175-6.

${ }^{48}$ Nubuwwät, 266.

49 Nubuwwät, 260; and Jahd, MF 9:141-2, 144/Mantiqiyyīn, 150, 153-4.

50 Tadmuriyya, MF 3:8-9; and Minhäj, 2:116/1:175-6.

${ }^{51}$ For the details of these arguments, see Herbert A. Davidson, Proofs for Eternity, Creation and the Existence of God in Medieval Islamic and Jewish Philosophy (Oxford, UK: Oxford University Press, 1987), 134-153.

52 Ibn Taymiyya, Dar', 8:348-358, and Fitra, MRK 2:346-7, notes that al-Juwaynī, alGhazālī, al-Rāzì and the Hanbalīs Abù Yàlā b. al-Farrā' and Ibn 'Aqīl all first held to the obligation of nazar and then later went back on its obligation. Geneviève Gobillot translates Ibn Taymiyya's Fitra in "L'Épître du discours sur la fitra (Risäla fì-l-kaläm 'alä-l-fitra) de Taqī-l-Dīn Ahmad Ibn Taymīya (661/1262-728/1328)," Annales Islamologiques 20 (1984): $29-53$. 
error. ${ }^{53} \mathrm{He}$ observes furthermore that not even the philosophers make their speculative methods an obligation since they do not regard their special knowledge to be available to the general populace. ${ }^{54}$ Rather, according to Ibn Taymiyya, God's origination of the human being after it was nonexistent is known directly by all through reason apart from prophetic revelation even though the prophets and the Qur'an also use this form of proof. 55

Beyond knowledge of God's existence, Ibn Taymiyya believes that basic religious and ethical truths are also known by reason. Reason knows that the Creator must be the sole object of worship and that nothing may be associated with Him. ${ }^{56}$ Reason also knows which human actions are good (basan) and which are bad (qabih). This is because good and bad reduce to the difference between suitability, pleasure, profit and benefit for the agent on one hand and unsuitability, incompatibility, pain, harm and detriment on the other. ${ }^{57}$ In this regard, the shaykh notes the view of Fakhr al-Dīn al-Rāzī that reason knows whether an act is an attribute of perfection (kamäl) or of imperfection (naqs). ${ }^{58}$ Ibn Taymiyya rightly remarks that only later Kalām theologians use such terms and that al-Rāzì got this from the philosophers. Be that as it may, the shaykh reduces perfection and imperfection also to pleasure and pain and the suitable and incompatible:

The perfection that occurs to the human being through some acts goes back to agreement and opposition, which is pleasure and pain. The soul takes pleasure in what is a perfection for it, and it suffers pain in the imperfection. So, perfection and imperfection go back to the suitable and the incompatible..$^{99}$

Similarly, Ibn Taymiyya relates other value terms to suitability and pleasure: "It is known that knowledge, justice, truthfulness and beneficence are suitable for humans and that they take pleasure in these. Moreover, their pleasure in these is greater than in anything else. This is what it means for an act to be good." ${ }^{\circ 0}$ In like manner, the terms good deed ( hasana) and evil deed (sayyia)

${ }^{53}$ Nubuwwät, 59-63ff., and Dar', 7:141-10:318, which gives an extensive treatment of the Kalām theologians' and philosophers' means of knowing God's existence.

${ }_{54}$ Dar' $^{3}, 10: 317$.

${ }^{55}$ Nubuwwāt, 71-2, 74.

56 Tawba, MF 11:682.

57 Ihtijäj, MF 8:308-9; Manțiqiyyin, 422; Tabsin al-'aql, MF 8:434-5; and Nubuwwāt, 139. There are also partial analyses of Ibn Taymiyya's theory of ethical value in Bell, Love Theory, 88-91; and Makdisi, "Ethics in Islamic Traditionalist Doctrine," 47-63.

58 Ibtijāj, MF 8:310. Al-Rāzīs view is found in his Muhasṣal, 202.

59 Ibtijāj, MF 8:310.

${ }^{60}$ Mantiqiyyin, 424. 
are a matter of pleasure and pain. ${ }^{61}$ I have not found the shaykh defining good (khayr) and evil (sharr) directly, but in their contexts they also relate to benefit (maslaha) and detriment (mafsada), profit (naf') and harm (darar), respectively. ${ }^{62}$ Nor have I found Ibn Taymiyya claiming that khayr and sharr are known by reason, although there would be nothing to prevent him from doing so. Generally speaking, value terms in Ibn Taymiyya’s discourse reduce to considerations of benefit and detriment. It is a special quality of human reason to know and seek profit and to know and repel harm. ${ }^{63}$

The shaykh contrasts his theory of ethical value with the theories of the Mu'tazilīs and the Ash'aris. What George Hourani calls the "rational objectivism" of the Mu'tazilis locates good and bad in objective qualities of acts themselves. An act is good or bad on account of an attribute essential to the act and necessarily concomitant with it. Thus, the value of this act is known by reason, and the function of God's command and prohibition is not to assign values to acts but to unveil them. Moreover, a bad act deserves chastisement in the hereafter even without the warning of a messenger. At the other end of the spectrum is Ash'ari divine voluntarism or "theistic subjectivism" (Hourani) in which good and bad depend solely on God's will. Acts are good or bad only because God commands or prohibits them. There are no attributes in acts making them good or bad. Their value can be known only by revelation. Ibn Taymiyya claims polemically that the Ash'arīs make God's command wholly arbitrary and devoid of regard for human benefit. ${ }^{64}$

As is already apparent, Ibn Taymiyya adopts a third view, a teleological or consequentialist ethic in which acts depend on their final benefit for their value. An act does not have an essential attribute (sifa dhätiyya) that makes it good or bad. Rather, something may be good, loved and profitable in some circumstances and bad, hated and harmful in others. ${ }^{65}$ Acts have attributes by

61 Ibtijāj, MF 8:309.

62 Irāda, MF 8:93-4; and Hasana, MF 14:268-9. Cf. Fātiḥa, MF 14:20-1. In Máārij, MF 19:169, Ibn Taymiyya connects good (khayr) directly to profit and benefit: "Good, happiness, perfection and benefit $(s a l a ̄ b)$ consist in two kinds: in profitable knowledge and beneficial deeds."

${ }_{63}$ Manțiqiyyin, 429; and Ihtijāj, MF 8:311.

64 Tabsin al-'aql, MF 8:431-3; Tawba, MF 11:675-7; Thulth, MF 17:198; and Minhäj, 3:177-8/2:33-4. Cf. Nubuwwāt, 139-142. See also Majid Fakhry, Ethical Theories in Islam, 31-5 and 46-52; George F. Hourani, Islamic Rationalism: The Ethics of 'Abd al-Jabbār (Oxford, UK: Clarendon Press, 1971), 8-14; Richard M. Frank, "Moral Obligation in Classical Muslim Theology," The Journal of Religious Ethics 11.2 (1983): 204-223; Sophia Vasalou, "Equal Before the Law: The Evilness of Human and Divine Lies: 'Abd al-Ğabbār's Rational Ethics," Arabic Sciences and Philosophy 13 (2003): 243-268, and Louis Gardet, Dieu et la destinée de l'homme (Paris: J. Vrin, 1967), 81-3.

65 Mantiqiyyin, 422. 
which they become good or bad, but these are accidental ('ärida) and must be considered in light of what is suitable (mulä im) or unsuitable (munäfir) to the agent. ${ }^{66}$ "The good [act] is that which procures what is loved, sought and intended for itself. The bad is that which procures what is hated and loathed." ${ }^{67}$ Some things like eating meat that has not been ritually slaughtered may be bad in some circumstances and good in others. ${ }^{68}$

Ibn Taymiyya claims wide consensus for the proposition that good and bad defined in this teleological and benefit-oriented manner are known rationally. ${ }^{69}$ This is in fact the case, especially among the philosophizing Ash'arī Kalām theologians that dominate the later medieval period. With beginnings in al-Juwaynī (d. 478/1085) and clear formulation in al-Ghazālī (d. 505/1111), later Ash' arīs interpret the Mu'tazilī objectivist notions of good and bad in terms of profit and harm, pleasure and pain, and suitability and unsuitability. Additionally, they hold that these effects are known by reason. However, later Ash'arīs maintain that reason cannot know whether an act is praiseworthy or blameworthy and rewarded or punished. This can be known only through the Law. ${ }^{70}$ Ibn Taymiyya is not sympathetic to this Ash'arī qualification, and he unsuccessfully tries to reduce it also to a matter of profit and harm. He argues, "In reality this controversy comes back to the suitable and the unsuitable, the profitable and the harmful. Blame and punishment are among the things that harm the servant and are unsuitable for him. ${ }^{\text {"71 }}$ While it is intuitive that blame and punishment cause pain and harm, this does not address the question of whether one knows about blame and punishment-especially in the hereafter-through reason. In a different text, Ibn Taymiyya does say that the ultimate ends of acts can be known only through the revealed Law: "Knowledge of the end which is the consequence of acts, that is, happiness and unhappiness in the hereafter, is known only by the Law." ${ }^{2}$

${ }^{66}$ Minhāj, 3:178/2:34.

${ }^{67}$ Minhäj, 3:29/1:270.

${ }^{68}$ Minhäj, 3:29/1:270.

${ }^{69}$ Tadmuriyya, MF 3:115; Iräda, MF 8:90; Ihtijiāj, MF 8:309; and Manțiqiyyin, 422-3.

Al-Julaynad, Qadiyyat al-khayr wa al-sharr, 252-8; Gardet, Dieu et la destinée de l'homme, 82-3; Sherman A. Jackson, Islamic Law and the State: The Constitutional Jurisprudence of Shihäb al-Din al-Qaräfì (Leiden: Brill, 1996), 23-32; and Felicitas Opwis, "Mașlaha in Contemporary Islamic Legal Theory," Islamic Law and Society 12.2 (2005): 182-223, at 188-189. See now Ayman Shihadeh, The Teleological Ethics of Fakhr al-Din al-Räzì (Leiden: Brill, 2006), 45-153, for a much more extensive and finer-grained discussion of the development of teleological ethics in Ash'arism culminating in al-Rāzī.

${ }^{71}$ Minhäj, 3:29/1:269. Cf. Aqwam, MF 8:90; and Iḥtijäj, MF 8:309.

72 Tadmuriyya, MF 3:115. 
This brings us to the relationship of the Law to the good and bad that is known by reason. Ibn Taymiyya asserts that God's command is directed toward the wise purpose ( $h i k m a$ ) and mercy of promoting human benefit. ${ }^{73}$ He writes, "[God] commanded and prohibited according to His knowledge of the benefits and detriments to servants in the command, the prohibition, the thing commanded and the thing forbidden." ${ }^{.74}$ Likewise, God raised up messengers to bring benefits and reduce detriments. ${ }^{75}$

Beyond this, the shaykh identifies three types of divine command. ${ }^{76}$ In the first, God's command and prohibition confirm that humans should do and not do what their reason already knows is good and bad, respectively. ${ }^{77}$ One example of this is the quranic verse, "[God] commanded them to the right and prohibited them from the wrong, and He made agreeable things lawful for them and forbade disgusting things for them" (Q. 7:157). Ibn Taymiyya says that this indicates that these things are right or wrong, agreeable or disgusting, apart from God's command. Otherwise, the verse becomes tautologous: "He commanded them what He commanded them..."78

Ibn Taymiyya clarifies that, in this first type, God does not punish acts known to be bad until He sends a messenger. He bases this on quranic texts such as "We do not chastise until We raise up a messenger" (Q. 17:15) and "Your Lord never destroyed the towns until He raised up a messenger in their leading town reciting Our verses to them. We never destroyed the towns unless their people were unjust" (Q. 28:59). ${ }^{79}$ God first sent messengers to condemn what was already known to be bad. This was followed by prohibition and warning of chastisement. ${ }^{80}$ The shaykh observes that this differs from the Ash'arīs for whom bad acts prior to revelation were as indifferent as eating and drinking and that it also opposes the Mu'tazilis for whom bad acts are punished even apart from the warning of a messenger. ${ }^{81}$

In dealing with an objection that there is no meaning to a bad act that is not punished, Ibn Taymiyya draws a distinction between two kinds of

${ }^{73}$ Mantiqiyyin, 237.

${ }^{4}$ Tabsin al-'aql, MF 8:434.

75 Minhāj, 3:84.

76 This three-fold typology occurs in Tabsin al-'aql, MF 8:434-6; and Thulth, MF 17:201-3.

77 Tabsin al-'aql, MF 8:434-5.

${ }^{78}$ Minhāj, 3:178-9/2:34.

79 Tabsin al-'aql, MF 8:435.

80 Tawba, MF 11:677-682.

81 Tabsin al-'aql, MF 8:435; Tawba, MF 11:680-1; MF 19:215; and Nubuwwät, 240. Despite Ibn Taymiyya’s polemic, the later Mu'tazilī Qư’an commentator al-Zamakhsharī holds an identical position. See al-Julaynad, Qadiyyat al-khayr wa al-sharr, 247. 
'bad' and two kinds of 'punishment' ('iqäb). First, bad means that the act is a cause of punishment of the kind that God deals out after a messenger's warning. Second, bad means blameworthy, imperfect and defective. Bad acts in this sense entail a "punishment of deprivation of good (birmän khayr)," which results from not doing what is better. Thus, those who commit bad acts before the arrival of messengers suffer the punishment of imperfection, but they do not suffer direct punishment from God. In this connection the shaykh also mentions that there are traditions reporting that those who have never received a messenger will have one sent to them on the Day of Resurrection. ${ }^{82}$

In the second kind of divine command and prohibition, an act becomes good or bad by the pronouncement of God, but it still entails benefit and detriment. Ibn Taymiyya notes that God may specify places like the Ka ba and times like the month of Ramadān in which to dispense greater quantities of His mercy, beneficence and blessing. As examples of this second kind of command, he also cites the prohibition against drinking wine. In response to the objection that the forbidding of wine was arbitrary, the shaykh says that God prohibited it at the time dictated by His wise purpose. Something may be profitable at one time and harmful at another, or something that is harmful may not be prohibited if its prohibition might result in greater detriment. In the case of wine, God did not prohibit it completely until the early Muslims had adequate faith to withstand its prohibition. ${ }^{83}$

The third type of divine command is the trial. The primary example Ibn Taymiyya mentions is God's command to Abraham to sacrifice his son. The shaykh explains that such a sacrifice would have brought no benefit. Rather, God tried Abraham to see whether his love for Him was greater than his love for his son. God's intention was to remove anything that might have come between them and to perfect Abraham's friendship with Himself. ${ }^{84}$

To sum up, Ibn Taymiyya believes that reason provides knowledge of God's existence, His right to exclusive worship, and the broad foundations of ethics.

82 Tawba, MF 11:686-7.

83 Thulth, MF 17:201-2; and Tabsin al-'aql, MF 8:435-6.

${ }^{84}$ Thulth, MF 17:203. Cf. Minhāj, 3:20/1:267. In another example, Ibn Taymiyya, Tabsin al-'aql, MF 8:436, and Thulth, MF 17:203, cites a hadith about a leper, a bald-headed man and a blind man in the collection of Bukhārī, 3205, Ahādīth al-anbiyā', Hadīth abraș wa a'mā wa aqra' fì Banī Isrāīl. In this hadith, God sent an angel to restore the skin, hair and sight of each of these men, respectively, and to grant them wealth. Then the angel appeared to them each as a needy traveler in their previous respective forms asking for help. Only the blind man responded. Then the angel told the blind man to keep his property because it was only a trial. 
The Law brings a higher level of accountability and some information about God's command and recompense that cannot be known otherwise, but the Law confirms and is fully compatible with what is known independently by reason. Although Ibn Taymiyyas teleological ethic sets him at odds with both poles in the traditional Ash'arī and Mu'tazilī debate over the rational discernment of good and bad, he is nonetheless firmly within the mainstream of later philosophizing Kalām views on ethical value. As we will see in later chapters, this position offers him a vantage point from which to polemicize against both the Mu'tazilī and Ash'arī positions on God's justice and on the relation of God's creation to God's command. The shaykh's teleological outlook also appears in the following treatment of another source of religious knowledge, the natural constitution.

\section{The Natural Constitution (fitra) and its Perfection through Prophecy}

The natural constitution ( fitra) in Ibn Taymiyya's thought is an innate faculty or knowledge that is closely linked to reason ('aql), but it is difficult to pinpoint the exact relationship. ${ }^{85}$ The shaykh occasionally uses ' $a q l$ and fitra or their derivatives in parallel. ${ }^{86}$ In other places, the natural constitution appears to be the basis for reason. For example, the shaykh speaks of "the rational methods (al-turuq al-aqliyya) that people endowed with reason know by their natural constitutions," ${ }^{87}$ and he writes, "What is intended by the term object of reason $\left(m a^{c} q \bar{u} l\right)$ is the clear object of reason that people know by their natural constitutions upon which they have been naturally constituted." ${ }^{88}$ However, the following statement could be cited to support the opposite thesis - that reason is the basis of the natural constitution-"Rational propositions (al-qadāyà al-'aqliyya) are the foundations

${ }^{85}$ Nurcholish Madjid, "Ibn Taymiyya on Kaläm and Falsafa: A problem of Reason and Revelation in Islam," (Ph.D. diss., University of Chicago, 1985), 85-7, argues that 'aql and fitra are synonymous in Ibn Taymiyyas thought, but he gives relatively little evidence for this. For an overview of fitra in various domains of Islamic thought, see Geneviève Gobillot, La fitra: la conception originelle: ses interprétations et fonctions chez les penseurs musulmans (Cairo: Institut français d'archéologie orientale, 2000). Also of interest is Camilla Adang, "Islam as the Inborn Religion of Mankind: The Concept of Fitra in the Works of Ibn Hazm," Al-Qantara 21 (2000): 391-410. 382.

${ }_{86}^{86}$ Fitra, MRK 2:341; MF 6:80; Ihtijäj, MF 8:311-2; and Jahd, 9:242/Manțiqiyyin,

${ }^{87}$ Nubuwwät, 76.

88 Jawāb, 4:395. 
of the natural constitutions of people endowed with reason (ușül fițar al'uqalä)." ${ }^{89}$

Many of the same things that Ibn Taymiyya says are known by reason are also known by the natural constitution. These include the basic rules of thought. God has placed knowledge of likeness and difference in the natural constitution..$^{90}$ It is known by the natural constitution that a body or person cannot be in two places at once. The shaykh adds that if in fact it appears that a person is in two places simultaneously, then one of the appearances is actually that of a jinn who has adopted the form of the person. ${ }^{91}$ As with reason, the shaykh also frequently claims that the existence of the Creator is known by the natural constitution through direct cosmological proofs. All human beings in their natural constitutions know necessarily that the creature needs a creator, maker and governor (mudabbir) and that an originated event needs an originator. Something possible needs a preponderator (murajib) to tip the scales in favor of its existence over its nonexistence. This fundamental affirmation of external determinative causality, or what may be called the 'principle of preponderance', corresponds to humanity's fundamental felt need for and dependence upon God. ${ }^{92}$ Even the insane are aware of their need for a creator. ${ }^{93}$

Wael Hallaq, in an article on Ibn Taymiyya's proofs for God's existence, points out that the shaykh's views of the natural constitution appear inconsistent. ${ }^{94} \mathrm{Ibn}$ Taymiyya sometimes presents the natural constitution as a means or faculty for knowing necessarily from created things that they must have a creator. Created things are signs pointing immediately to God. At other times, however, he regards the natural constitution as an inborn knowledge of God requiring no evidence whatsoever. In this vein, he argues that natural constitutions must know the Creator without signs: "If [the natural constitutions] had not known Him apart from the signs, they would not have

MF 12:229.

Jahd, 9:242/Manțiqiyyin, 382.

11 Jawāb, 4:397.

92 Furqän, MF 13:151; Fì Wujūb, MF 1:45,47; Iräda, MF 8:136; Dar', 8:348; and Fitra, MRK 2:341, 344-5, 348.

${ }_{93}$ Fitra, MRK 2:337. Ibn Taymiyya also claims in Hamawiyya, MF 5:15, that it is known by the natural constitution that God is above the sky.

${ }_{94}$ Wael B. Hallaq, "Ibn Taymiyya on the Existence of God," Acta Orientalia 52 (1991): 49-69, argues that Ibn Taymiyya reserves the term 'aql for the faculty conducting inferential operations (55). In view of the presentation of 'aql above, I do not believe that this is sustainable because ' aql, like fitra, includes innately held principles and beliefs. 
known that these signs [pointed] to Him." 95 Hallaq observes that the latter argument is circular and that it contradicts the former.

Further investigation shows that Ibn Taymiyya probed the matter more deeply, especially in the direction of the natural constitution being a faculty, yet one that necessarily entails knowledge of the Creator without signs. To examine this, it is helpful to begin with the textual basis for the doctrine of the natural constitution, a hadith found in the collections of Bukhārī and Muslim:

Every newborn is born with the natural constitution. Then, his parents make him a Jew, Christian or Zoroastrian. This is like an animal that bears another that is perfect of limb. Do you sense any mutilation in it? Then Abü Hurayra said: If you wish, recite, "The natural constitution ( fitra) of God according to which He has constituted ( fatara) humanity" (Q. 30:30). ${ }^{96}$

The shaykh interprets the natural constitution in this hadith to be the religion of Islam, and he connects this to the covenant God made with all humanity in primordial time, "[The Lord said], 'Am I not your Lord?' They said, 'Yes, indeed"' (Q. 7:172). However, he explains that this Islam does not exist in actuality $\left(b i-l-f_{i} l\right)$ at birth because the newborn does not have knowledge of anything. Yet, as his innate potency (quwwa) of knowledge and will become active, the knowledge of God that the natural constitution entails arises as well so long as there are no impediments. ${ }^{97}$

In a part of $D a r^{\prime}$ not accessible to Hallaq, Ibn Taymiyya observes that teaching is not a sufficient condition for imparting knowledge. ${ }^{98}$ Teaching animals and inanimate objects does not yield the same results as teaching human beings. There must be a potency entailing knowledge and will that is receptive to what is taught, and this potency is created so as to preponderate the true religion over any other. It is possible that inner voices (khawātir) in the soul alert it to the true religion without external teaching, and, apart from corrupting influences, this will indeed happen. To deal with the problem of circularity, the shaykh still has resort to external determinative causes. He says that these inner voices arise through the inspiration of an angel or

${ }^{5}$ Fì Wujüb, MF 1:48; and Hallaq, "Ibn Taymiyya on the Existence of God," 65.

${ }^{96}$ Bukhārī, 1270, Al-Janāiz, Idhā aslama al-ṣab̄i fa-māta; Bukhārī 1296, Al-Janā’iz, Mā qīla fì awlād al-mushrikīn; Muslim, 4803-7.

${ }_{97}$ Dar' $^{\prime}$ 8:460-1; and MF 4:245-9. Texts from MF 4:245, 427, are translated alongside Amräd, MF 10:132-6, in Yahya M. Michot, "Pages spirituelles d'Ibn Taymiyya: IX. La finalité du coeur," Action (Mauritius), July 2000, 18-9, 26.

${ }^{98}$ Dar', 8:359-468. Hallaq uses Muwāfaqat sahīh al-manqūl li-sarīh al-máqül, ed. Muhammad Muhyī al-Dīn 'Abd al-Hamīd and Muhammad Hāmid al-Fiqī (Cairo: Maṭba'at al-sunna al-muhammadiyya, 1370/1951), which corresponds to Dar', 1:2-3:87, only. 
other causes (asbäb) that God originates. Yet, he insists that they do not arise from human teaching and calling. Guidance through human intermediaries is not a necessary condition for knowing the true religion. Ibn Taymiyya compares the natural constitution to an infant's instinct for his mother's milk. If nothing impedes the infant, such as illness in himself or his mother, he will necessarily drink. The shaykh adds that the natural constitution to believe in God is even stronger than the infant's instinct.9 ${ }^{9}$

In Ibn Taymiyya's view, the natural constitution also dictates what is good for humans to do and love. God has constituted humans to will naturally what is profitable for them and repel what is harmful: "The [human being] has been naturally constituted to will what he must inevitably have and to hate what harms him and injures him." ${ }^{100}$ This corresponds to loving what is good and right and hating what is bad and wrong. Justice ( $\mathrm{C} a \mathrm{dl}$ ) is good because it is beloved to the natural constitution and yields pleasure, joy and profit to oneself and others. Injustice $(z u l m)$ is bad because the natural constitution knows that it is hateful and causes pain, trouble and torment. Humans have been naturally constituted to love and find pleasure in justice, truthfulness, beneficence and knowledge just as they have been naturally constituted to find pleasure in food and drink. ${ }^{101}$ Moreover, God has naturally constituted human beings to love and worship Him alone. To be a willing being is an essential concomitant of the natural constitution. A willing being necessarily has a god toward which it directs its love and which it loves for itself. Apart from corrupting influences, this ultimate object of the natural constitution's will and love will be God. Thus, a child left on his own will necessarily come to know, praise, love and worship his Lord. ${ }^{102}$ In Dar', Ibn Taymiyya sums up the religion of the natural constitution in terms of exclusive worship of God as the end for which creatures are created and the "lawfulness of good things" as the means toward this end:

The foundation of the religion upon which God naturally constituted His servants—as He said, "I have created My servants original believers ( bunafä).

${ }_{99} \mathrm{Dar}^{\text {' }}$, MF 8:461-4. In Mababba, 9 and 23, Ibn Taymiyya gives angels the role of bringing forth all the motion in the universe that lies outside the capability of humans, jinn and animals.

100 'Abd al-Qädir, MF 10:481. Similarly, 'Abd al-Qädir, MF 10:465; and Minhäj, 3:64/2:5, 3:69/2:6

${ }^{101}$ Mantiqiyyin, 423. Cf. Manțiqiyyin, 429, "Souls are naturally disposed (majbüla) to love justice and its people and to hate injustice and its people. This love, which is in the natural constitution, is what it means for [justice] to be good."

102 Fitra, MRK 2:338; Dar', 8:464-8; Manțiqiyyìn, 423; Maḅabba, 44-5; Fī Wujūb, MF 1:25-7; Amräd, MF 10:135; 'Abd al-Qädir, MF 10:474; and Hasana, MF 14:296. 
Then, satans turned them away, forbade them what I had made lawful for them, and commanded them to associate to Me that to which I had not given authority"103 - this combines two foundations. The first of them is worship of God alone without associate. He is worshipped only through what He loves and has commanded. This is the objective for which God created creatures. Contrary to this is associationism and innovation. Second is the lawfulness of agreeable things (tayyibät) in which help is sought toward the objective. This is the means (wasila). Contrary to this is forbidding the lawful. ${ }^{104}$

Despite Ibn Taymiyya's optimistic view of the natural constitution's ability to know God and the purpose of worship for which it was created, the above quotation also indicates that it may become corrupted by satans (shayațin). In scattered references, the shaykh cites many things that may corrupt the natural constitution. In addition to satans from among humans and jinn, ignorance and heedlessness play a detrimental role. ${ }^{105}$ As noted in the hadith on the natural constitution, parents may make a child a Jew, Christian or Zoroastrian. ${ }^{106}$ Also, vain doctrines may corrupt the natural constitution "like a veil blocking the eyesight from seeing the sun." ${ }^{107}$ Pride, ill purposes, and divided love for God all exert their corrupting influences. ${ }^{108}$

In view of corrupted natural constitutions, Ibn Taymiyya notes that one of the best ways to reach necessary knowledge is through purifying the soul and spiritual disciplines. ${ }^{109}$ Inferential methods may also be needed and even obligatory to discern the existence of the Creator. ${ }^{110}$ However, Ibn Taymiyya distinguishes between the invalid rational inquiry (nazar) of Kalām theology on the one hand and the valid nazar of examining the guidance brought by the Messenger and inferring the Creator from the existence of the human being on the other. ${ }^{111}$ It is in fact part of the role of messengers, the Qur'an and the Sunna to make the correct rational proofs obvious to those whose natural constitutions have become corrupt. ${ }^{12}$ In addition to revealing details of the Law that cannot be known by the natural constitution, messengers have been sent to those who have suffered corruption in order to set the

\footnotetext{
103 Muslim, 5109, Al-Janna wa șifāt na īmihā, Al-Ṣifāt allatī yư raf bihā fī al-dunyā ahl al-janna....

104 Dar' $^{\prime}, 8: 455$.

105 Hasana, MF 14:296-7.

106 Amräd, MF 10:135.

107 MF 4:247.

108 Minhāj, 5:403/3:101.

109 Fitra, MRK 2:341.

110 Fitra, MRK 2:341, 345.

111 Nubuwwāt, 62-73; and Máārij, MF 19:172.

112 Jahd, 9:242/Mantiqiyyin, 382.
} 
natural constitution back on the right path and complete and perfect it. ${ }^{113}$ The following passage from Ibn Taymiyya's Nubuwwāt elaborates this:

The Prophet, he and the rest of the believers inform only of the truth. They command only justice. They command the right and they prohibit the wrong.... They were raised up to perfect the natural constitution and firmly establish it, not to replace it and change it. They command only what agrees with what is right to rational minds which pure hearts accept with receptivity. So too, they themselves did not differ, and they did not contradict one another. Rather, their religion and their faith were one even if the laws were of diverse kinds. They also agree with the obligation of the natural constitution according to which God constituted His servants. [They] agree with rational proofs and do not contradict them at all.... The prophets perfected the natural constitution and made humankind see. As has been said concerning the description of Muhammad-God bless him and give him peace-that through him God opens the eyes of the blind, the ears of the deaf and hearts that are closed. Their opponents corrupt sense perception and reason just as they have corrupted the proofs of revelation. ${ }^{114}$

A similar passage in another work points to the role of messengers in perfecting the natural constitution for the sake of blessing in Paradise.

God-Exalted is He-raised up the messengers to perfect the natural constitution. They indicated to human beings that by which they obtain blessing in the hereafter and are saved from the chastisement of the hereafter. The difference between what is commanded and what is forbidden is like the difference between Paradise and the Fire, pleasure and pain, and blessing and chastisement. ${ }^{115}$

The role then of prophets and messengers for Ibn Taymiyya is purifying humans of corrupting influences and perfecting the natural constitution in which they were created, which is to love God alone and dedicate their religion solely to Him. ${ }^{116}$ This involves pointing to what is known to be just and right in reason and guiding them on the path to Paradise. Prophecy and revelation are fully congruent with and the perfection of what all human beings have naturally constituted within them.

113 Minhāj, 1:300-1/1:82; Manțiq, MF 4:45; Jahd, MF 9:242-3/Manțiqiyyin, 382; and 'Abd al-Qädir, MF 10:466.

${ }_{114}$ Nubuwwāt, 430-1. Mahabba, 62, makes a similar affirmation.

115 Ibtijajj, MF 8:312.

116 Amräd, MF 10:135. 


\section{Connections to Ibn Taymiyya's Theodicean Writings}

The previous two subsections show that reason and the natural constitution constitute two functionally equivalent sources in Ibn Taymiyya's thought for attaining knowledge of God's existence and the ends to which human beings should devote themselves. Apart from prophetic revelation, human beings, by virtue of their very createdness, know that God exists, that the fundamental human telos is to gain benefit and repel detriment, and that this may be achieved most fully in worshipping and loving God. Prophecy and revelation of God's command restore and perfect these basic human intuitions.

Certain rational difficulties arise from Ibn Taymiyya's ethical vision. His view of the powers of the natural constitution to recognize and follow truth is very optimistic, and it does not appear to take into account the problem of inveterate unbelievers for whom prophecy and spiritual discipline do not avail. It is insufficient to pass the blame off on satans because this only pushes the question back one step to how even the natural constitutions of the satans were corrupted. From whence then does evil ultimately come? A similar problem exists with respect to reason. If humans know by reason what will profit and harm them, why do they go astray, and if it is a matter of God creating disbelief and disobedience in them-as Ibn Taymiyya asserts-then how is God just to create that, much less punish it? The shaykh attends to these problems in several places, but most fully in Hasana, which will be examined in Chapter Five.

Beyond this, two key principles underlying the material above will reappear in subsequent chapters. First, Ibn Taymiyya's cosmological proof for God's existence is rooted in the metaphysical presupposition that every possible and originated existent requires an external cause preponderating and determining its existence. As will become apparent in Chapter Two below, the shaykh usually upholds this principle of preponderance with an extraordinary rigor that extends even into God's will. Second, as already noted above, the shaykh rejects Mu'tazilī rational objectivism and Ash' arī voluntarism in favor of a teleological theory of ethical value. At first glance, this appears to apply not only to the human plane but to God as well, especially as Ibn Taymiyya underlines the causal character of the wise purposes in God's creative acts (Chapter Two). An important question then is whether the shaykh applies the two principles of preponderance and teleology to God univocally or in some other fashion. What follows on the character of theological discernment of God's attributes begins to suggest how the shaykh might answer this question. 


\section{The Methodology of Theological Jurisprudence}

To Ibn Taymiyya's mind, both reason and the natural constitution on the one hand and Law and prophecy on the other affirm that God exists and that God should be loved and worshipped. Beyond this, the revealed tradition also ascribes various qualities and acts to God that resemble those of creatures. But what is reason to make of these? More pointedly, what should be the response to God's messengers who bring information about God-such as God's sitting (istiw $\vec{a})$ on the Throne (Q. 57:4) - that apparently conflicts with rational proofs demonstrating God's incomparability with creatures? Ibn 'Arabī in Al-Futūhät al-makkiyya provides a typology of responses to this question that will help situate Ibn Taymiyya's approach. ${ }^{117}$

The first of six groups outlined by Ibn 'Arabī responds by doubting the truthfulness of the messenger and turning away from the faith when informed that God has attributes that are normally ascribed to originated things. This is simply unbelief. The second group does not waver in its faith and retains its rational proofs, but it takes the messenger's report to be a wise adaptation to the weak who do not have access to the proofs of reason. Ibn 'Arabi does not link names to any of the groups, but this second group represents the basic position of Muslim philosophers like al-Farābī, Ibn Sīnā and Ibn Rushd. ${ }^{118}$ The third group believes that the report of God's self-description contradicts its proofs negating all ascriptions of creaturely attributes to God, but it accepts the truthfulness of the report-giver nonetheless and submits to his greater knowledge since there is no harm in this. Still, the relation of this description to God Himself is not known since God's essence is not known. Here Ibn 'Arabī may have in mind traditionalists who affirm God's description of Himself in revelation but refuse to interpret its meaning, especially in the way practiced by the next group. Yet, there is little to distinguish this position from his own which he affirms and elaborates at the end of the typology.

${ }_{117}$ Ibn 'Arabī al-Hātimī al-Ṭāì̄, Al-Futūhāt al-Makkiyya, 4 vols. (Beirut: Dār Ṣādir, n.d.), 2:306-7, translated in William C. Chittick, The Sufi Path of Knowledge: Ibn al-Arabi's Metaphysics of Imagination (Albany, NY: State University of New York Press, 1989), 186-7.

${ }_{118}$ On the philosophers' views of prophecy, see F. Rahman, Prophecy in Islam: Philosophy and Orthodoxy (London: George Allen \& Unwin, 1958), 36-45, and Richard C. Taylor, "Averroes: religious dialectic and Aristotelian philosophical thought," in The Cambridge Companion to Arabic Philosophy, eds., Peter Adamson and Richard C. Taylor (Cambridge, UK: Cambridge University Press, 2005), 182-9. On Ibn Taymiyya's rejection of the philosophers' perspective, see Michot, "A Mamlūk Theologian's Commentary." 
The fourth group, clearly the Kalām theologians, accepts the truthfulness of the report-giver but re-interprets $\left(t a^{3} w \bar{i} l\right)$ the apparent $(z \bar{a} h i r)$ sense of some reports to accord with its rational proofs, which, this group observes, are congruent with God's statement about Himself, "There is nothing like Him" (Q. 42:11). The fifth group has no appreciation for rational proofs of God's incomparability and does not grasp the meaning of "There is nothing like Him." Rather, it takes the revealed descriptions of God in their apparent sense without drawing a distinction between themselves and God. This is the anthropomorphism and corporealism that the Islamic heresiographical tradition often ascribes to Hadith scholars under the pejorative label Hashwiyya. It is also what many of Ibn Taymiyya's opponents from his own day onward understand him to teach. ${ }^{119}$

Ibn 'Arabî's sixth and last group, the one approved as attaining salvation, "has faith in what came from God as God means it and knows it, while negating assimilation (tashbih) [of God to creatures] with 'There is nothing like Him' (Q. 42:11)." ${ }^{120}$ Ibn 'Arabī continues with a long list of creaturely attributes which revelation has ascribed to God-including inter alia a hand, hearing, sight, good pleasure, hesitation (taraddud), joy, laughter and descent-many of which the Kalām theologians seek to reinterpret.

Given Ibn Taymiyya's notoriety for polemic against Ibn 'Arabī, it may seem odd to resort to a typology from the latter to enlighten the views of the former. Yet, from the following exposition of Ibn Taymiyya's view, it will become apparent that the two agree on one thing. With the sixth group above, both affirm allegedly anthropomorphic expressions about God on a par with other divine attributes found in revelation while simultaneously confessing that God is equally incomparable to creatures in all of His names and attributes. Neither follows the philosophers for whom revelation is an expedient for the masses who cannot bear pure intellectual truth. Nor does either adopt the hermeneutical strategy of Kalām theology, which argues that revelation must give way to reason through the practice of re-interpretation $\left(t a^{3} w i l\right)$. Nor may either of them be accused of the simplistic anthropomorphism and corporealism of the Hashwiyya.

119 Following Ibn Taymiyya's unsympathetic biographer Ibn Hajar al-'Asqalānī, Ignaz Goldziher, The Zähiris: their doctrine and their history, trans. and ed. Wolfgang Behn (Leiden: Brill, 1971 [1884]), 174, reports baldly that Ibn Taymiyya taught tajsim, that is, corporealism or giving God bodily characteristics.

${ }_{120}$ Ibn 'Arabī, Futühāt, 2:307; translation adapted from Chittick, The Sufi Path of Knowledge, 187. 
Ibn Taymiyya and Ibn 'Arabī do differ at significant points, and two of these need to be clarified here. Ibn Taymiyya does not follow the Sufi theorist in privileging mystical experience or revelation over reason. Rather, reason and revelation are on the same level and provide much of the same information about God. As we will see below, reason rightly exercised knows even many of God's allegedly anthropomorphic attributes found in revelation.

The two great figures also do not agree on the ontological referents of God's attributes and acts. Ibn 'Arabī does not always distinguish God's acts from created things, and from a certain illumined perspective, God's acts are the created things themselves. God's attributes and names then indicate the diverse relationships between God's many acts and God's one unknowable essence, but these relationships (i.e. the attributes) do not exist in reality. ${ }^{121}$ Ibn Taymiyya, unlike Ibn 'Arabī whom he charges with conflating God and the world, maintains that God's attributes are real and that not only God's essence but also God's attributes and acts are always ontologically distinct from creatures: "There is nothing like (mithl) [God], neither in His essence, nor in His attributes, nor in His acts." 122

Nevertheless, Ibn Taymiyya acknowledges that the unseen world, which includes both God and the hereafter, can be discussed only through the medium of what is known in the visible world: "Things that are concealed from sight and feeling are only known, loved and hated via a kind of likening (tamthill) and analogy (qiyass)."123 The question then is how to speak correctly of the God who is wholly other. Ibn Taymiyya answers this question from the tradition and with rational arguments concerning what human conception of God's perfection should entail.

\section{Affirming God's Attributes in the Revealed Tradition without Modality}

Contributing perhaps to his anti-rationalist reputation, Ibn Taymiyya often calls for acceptance of God's attributes found in the authoritative textual sources of Islam without making a parallel appeal to reason, asserting that God must be spoken of strictly as He has revealed Himself to be and as the

${ }^{121}$ For explanation of Ibn 'Arabī's theology, see Chittick, The Sufi Path of Knowledge, $8-12$ and 33-46.

122 Isfahāniyya, 9; Tadmuriyya, MF 3:25; Wasiyya kubrä, MF 3:374; MF 5:195; Nuzūl, 5:330; Jawāb, 2:164, 4:428; and Minhäj, 3:151/2:27. On God having his essence and attributes "in reality (baqiqatan)," see MF 5:196-9. For brief note of Ibn Taymiyya's polemic against Ibn 'Arabī's ontology, see below Chapter Three.

${ }^{123}$ Mahabba, 214. Cf. Tadmuriyya, MF 3:57. 
Prophet speaks of Him. This approach rests on the quranic verse, "There is nothing like Him, and He is all-Hearing, all-Seeing" (Q. 42:11), which the shaykh understands to entail both a negation of God's likeness to any creature and an affirmation that God has attributes called hearing and seeing. By extension, all other attributes that appear in the authoritative texts must be affirmed as they are, but always with the qualification that they are wholly unlike those of creatures. A typical statement of this position occurs in Ibn Taymiyya’s Tadmuriyya creed:

God is qualified by that with which He has qualified Himself and by that with which His messengers have qualified Him, negatively and positively. What God establishes for Himself is established and what He negates for Himself is negated. It is known that the way of the Salaf of the Community and its Imāms is establishment of the attributes (sifät) that He establishes without [giving them] modality (takyif) or likening [them to something else] (tamthil) and without distorting [them] (tahrif) or stripping [them] away $\left(t a t^{t} t i l\right)$. Likewise, they negate of Him what He negates of Himself....

Their way involves establishing His names and attributes, as well as negation of His likeness with creatures-establishing without assimilating [Him to creatures] (tashbih), declaring [Him] incomparable (tanzih) without stripping away [His attributes]. As $\mathrm{He}-$ Exalted is $\mathrm{He}-$ said, "There is nothing like Him, and He is all-Hearing, all-Seeing” (Q. 42:11). In His statement, "There is nothing like Him," is a rejection of assimilation and likening, and His statement, "He is all-Hearing, all-Seeing," is a rejection of heresy (ilhäd) and stripping away. ${ }^{124}$

Adhering to these guidelines, God must be mentioned only in the theological language of the Qur'an and the Sunna. The admonitions against takyif, tamthil, tashbīh, tahrîf and tát til protect this language from interpretation that ties God to creatures in some fashion. Ibn Taymiyya supports his rejection of assimilation (tashbīh) and likening (tamthill) with several quranic verses indicating that God has no son, associate or equal (Q. 2:22, 2:165, 16:74, 19:65, 25:2, 112:3-4, etc.). He also provides numerous verses establishing that God has various names and attributes and that God is the Creator of created things. For example, God is Self-Subsistent (al-Qayyum) and Living (Q. 2:255), all-Knowing and all-Wise (Q. 4:26). He created the heavens and the earth and then sat upon the Throne (Q. 57:4). He loves (Q. 5:54) and

124 Tadmuriyya, MF 3:3-4. Other basic creedal statements of this kind include Hamawiyya, MF 5:26; Isfăhäniyya, 9-10; Wäsitiyya, MF 3:129-130; Minhäj, 2:111/1:174; and Jawäb, 2:163-4, 4:405 (Jawāb, 4:384-411 is translated in Michel, A Muslim Theologian's Response to Christianity, 327-341). 
gets angry (Q. 4:93). He spoke to Moses (Q. 4:164). He is Creator, and to Him belong the most Beautiful Names (Q. 59:24). ${ }^{125}$

Ibn Taymiyya further explains that attempts by philosophers and Kalām theologians to understand the detail of the revealed language about God begin from alien conceptual frameworks and lead to error. Those who make God analogous to creatures or liken God to them violate His incomparability and end up worshipping an idol. A philosophical via negativa strips away God's positive attributes $(t a t i z l)$ and leads to worship of a nonexistent. Moreover, those who negate God's attributes only do so because they have first likened these attributes to those of creatures and found them unfit for God. In this way, even the strippers are likeners. In sum, the language about God presented in the revealed sources must be accepted as it is without it implying any likeness of God to creatures whatsoever. ${ }^{126}$

The shaykh's agnosticism as to the modality of God's attributes becomes especially apparent when he argues that they remain unique to God even if He has identified Himself with names and attributes that are also employed with respect to creatures. The shaykh elaborates this with a philosophical nominalism that denies the existence of extramental universals. Wael Hallaq comments that Ibn Taymiyya holds individuals in the extramental world to be "so distinct and different from one another that they cannot allow for the formation of an external universal under which they are assumed."127 The shaykh explains that God calls Himself Living, Knowing, Merciful,

125 Tadmuriyya, MF 3:4-7; and Jawāb, 4:405-8. A full list of quranic verses that negate God's likeness to creatures and affirm His many names and attributes is found in Wäsitityya, MF 3:130-143.

126 Tadmuriyya, MF 3:7ff.; Jawāb, 4:405-6; and Hamawiyya, MF 5:27, 59. Also, see especially Henri Laoust, "Quelques opinions sur la théodicée d'Ibn Taimiya," Mélanges Maspero, Vol. 3, Orient Islamique (Cairo: Imprimerie de l'institut français d'archéologie orientale, 1935-40), 431-8, which argues that Ibn Taymiyya is not the anthropomorphist that earlier western scholarship and a good part of the Islamic tradition had made him out to be. Sherman Jackson, "Ibn Taymiyyah on Trial," 53-6, discusses the same matter briefly but with greater technical depth. Other discussions in the secondary literature include Laoust, Essai, 155-7; Victor E. Makari, Ibn Taymiyyah's Ethics: The Social Factor (Chico, CA: Scholars Press, 1983), 34-41; Serajul Haque, "Ibn Taymīyyah: A Life and Works," in A History of Muslim Philosophy, ed. M. M. Sharif (Wiesbaden: Otto Harrossowitz, 1966), 2:796-819 (at 799-803); and Michel, A Muslim Theologian's Response to Christianity, 1-3, 5-23 passim, 41-4.

${ }^{127}$ Hallaq, Ibn Taymiyya against the Greek Logicians, xxii. Hallaq's reference for this point leads to $D a r^{3}, 1: 116$, where Ibn Taymiyya argues for the complete unlikeness of all individual entities, including all human beings, from each other. The shaykh quotes the verse, "If you turn away, He will exchange you for some other people, and they will not be your likes (amthäl)" (Q. 47:38). From this, he denies that humans bear a likeness (mumäthala) one to another even though they may share in having bodies, moving, laughing and so forth. By denying all likeness even between creatures, Ibn Taymiyya applies the same agnosticism that he holds with respect to the modality of God's attributes to the modality of human attributes. 
Hearing, Seeing and so on and that in the Qur'an He has used these names for creatures as well. However, God and creatures share nothing in common but these names.

Ibn Taymiyya does observe that the mind recognizes shared qualities and connotations when these names are abstracted from their particular and concrete manifestations. This is as when we recognize that both snow and ivory share something in common with each other that we call whiteness even though the whiteness of snow is much more intense than the whiteness of ivory. Yet, despite observed similarities, the shaykh asserts that the abstract universal of whiteness or any other name has no existence outside the mind. Applying this nominalism in the realm of theological language, there is no longer any similarity between the referents of identical names when they are particularized in the Creator and the creature apart from the very names themselves. The shaykh suggests that this is obvious, for example, in the attribute of knowledge. The knowledge of creatures is accidental, originated, and acquired whereas that of the Creator is none of these. The modalities of the concrete realities to which the names of the unseen God refer are unknowable because they are completely unlike referents given the same names in the created world. ${ }^{128}$

This rigorously agnostic and nominalistic approach permits affirming all the revealed names and attributes of God without fear of anthropomorphism because all of them are equally unlike their counterparts in the created world. A sample of Ibn Taymiyya's dialectic against the Kalām theologians from Tadmuriyya illustrates how this works. He takes particular issue with the Kalām theologians interpreting God's love, good pleasure, anger and hate as metaphors for either God's will or God's blessing and punishment of human beings. He explains, for example, that if the Kalām theologians understand God's will to be like that of creatures, then there should be no offense in making God like creatures in other attributes as well, such as in love and anger. Conversely, they might take God to have a will uniquely befitting Him just as creatures have wills uniquely befitting them and different from God's. In this case, however, there should be no reason not to affirm love

${ }_{128}$ Tadmuriyya, MF 3:10-16; Jawāb, 4:421-8; Minhäj, 2:112-120/1:174-7; Jahd, MF 9:145/Mantiqiyyin, 154-5; and Munäzara, 3:191. My discussion avoids the highly technical vocabulary Ibn Taymiyya uses because the main point is otherwise clear: the link between God's attributes and those of creatures is confined to the level of abstract universals in the mind. For discussion of the technical terms involved-tawätu', tashkik and ishtiräk-see Jackson, "Ibn Taymiyyah on Trial," 54-5; Hallaq, Ibn Taymiyya against the Greek Logicians, 74-5; and especially Mohamed M. Yunis Ali, Medieval Islamic Pragmatics: Sunni Theorists' Models of Textual Communication (Richmond, Surrey, UK: Curzon Press, 2000), 114-125. 
and anger of God in a sense uniquely befitting Him as well. Moreover, if the Kalām theologians take anger to be "the boiling of the blood of the heart from seeking vengeance" and then say that this cannot be applied to God, it can be countered that will means "the inclination of the soul to obtain profit or repel harm" which also cannot be applied to God. Anger and will in the anthropomorphic senses of these definitions are equally inapplicable to God because neither God's anger nor God's will bears any relationship to the human senses of anger or will. Rather, Ibn Taymiyya argues, God has an anger and a will that uniquely befit Him. ${ }^{129}$

The shaykh also notes that the Kalām theologians establish some of God's attributes by rational proofs and imply that those attributes not proven rationally must be reinterpreted. For example, the theologians argue that a temporally originated act proves that God has power, will and knowledge. These attributes necessarily imply life, and that which is living must be hearing, seeing and speaking. Then, other attributes like love and anger, which are not proven rationally, may not be predicated of God except as metaphors for the rationally proven attributes. Ibn Taymiyya retorts that absence of proof does not necessarily imply that something does not exist. Furthermore, rational proofs of a similar kind could be marshaled in support of God's other attributes. For example, God's beneficence to humans proves His mercy; His punishment of unbelievers points to His hate; and so on. ${ }^{130}$

Ibn Taymiyya's hermeneutic presupposition throughout these arguments is an absolute application of "There is nothing like Him" (Q. 42:11), which he complements with a rigorous nominalism that denies the existence of extramental universals. On the basis of God's complete unlikeness, the shaykh portrays the Kalām theologians as inconsistent in their attempt to set apart some of God's attributes as metaphorical and in need of reinterpretation ( $\left.t a^{\prime} w i l l\right)$ while taking other attributes in senses common to creatures. Ibn Taymiyya understands God's names and attributes neither literally nor metaphorically. What is literal or absolute is that the names and attributes refer to realities wholly beyond human comprehension. While God's attributes may connote certain things in the human mind, these thoughts do not correspond to anything in the modality of the attributes of God Himself.

129 Tadmuriyya, MF 3:17-8. Bell, Love Theory, 64-5, recounts similar arguments from Iklïl, MF 13:298-300.

130 Tadmuriyya, MF 3:18-9. 


\section{Giving Meaning to the Revealed Attributes in Human Language}

Absolute unlikeness between God and creatures may present difficulties for the religious life insofar as the language about God does not connect to anything concrete in human experience. ${ }^{131}$ Sherman Jackson argues that Ibn Taymiyya's view of God's names and attributes does, however, represent an advance over the earlier Hanbalī Ibn Qudāma. Ibn Qudāma sets out his position as follows:

We have no need to know the meaning of what God-Exalted is $\mathrm{He}$-intended by His attributes-He is Great and Almighty. No deed is intended by them. No obligation is linked to them except belief in them. Belief in them is possible without knowing their meaning. Indeed, belief with ignorance is correct. ${ }^{132}$

Whereas Ibn Qudāma rejects any attempt to link God's attributes to the referential world of ordinary human language, Ibn Taymiyya acknowledges that God's attributes do connote certain qualities in the mind although not in the external world. In the following quote, Jackson suggests that these mental associations give more tangibility to religious language than does the full agnosticism of Ibn Qudāma.

On this approach, a badith such as the one asserting God's descent to the lower heavens to offer forgiveness to repentent $[s i c]$ sinners is transformed from an abstract mystery into a concrete promise of immanent grace. For, what is understood by 'descent' is now informed by its meaning in the case of created entities, without this entailing, meanwhile, the belief that God actually descends like anything created. ${ }^{133}$

While the associations that God's attributes and acts evoke in the mind may bring blessing and comfort of a kind, it seems doubtful that what Jackson calls a "concrete promise of immanent grace" is in fact concrete because it does not correspond to anything humans experience in concrete reality. Nonetheless, Ibn Taymiyya does differ from Ibn Qudāma in taking these connotations very seriously and giving considerable attention to the meanings of the words that are used for God's attributes. He delineates these meanings

${ }^{131}$ For a sociological analysis of this outlook not only in Ibn Taymiyya but among the Hanbalis in general, see Aziz Al-Azmeh, "Orthodoxy and Hanbalite Fideism," Arabica 35 (1988): 253-266, who observes that doctrinal language in this view is equivalent to a technical language that is "not native to the human understanding" (257). He argues further that this position was sustained through the rigorous transmission of texts claiming to preserve the original revelation and through the structures of Hanbalī authority that included charismatic preaching and miraculous signs.

132 Ibn Qudāma, Tahrim al-nazar, 51-2.

133 Jackson, "Ibn Taymiyyah on Trial," 56. 
by reference to the authoritative tradition of the Qur'an, the Hadith, the Salaf, the early Qur'an exegetes and the conventions of the Arabic language, as well as by rational considerations.

Ibn Taymiyya's discussion of God's attribute of sitting on the Throne (cf. Q. 20:5, 25:59), especially as it appears in his Hamawiyya creed, provides an example of how this works. Basic to the argument are the distinctions Ibn Taymiyya draws between three types of $t a^{2} w i \bar{l}{ }^{134}$ First is the $t a^{3} w i \bar{l}$ of the Kalām theologians and others who turn away from the probable meaning and adopt the less probable meaning on account of some proof for this. In the case of God's sitting, the shaykh in Hamawiyya castigates the Mu'tazilis for reinterpreting God's sitting (istawā) as possessing (istawlā) in order to reconcile it with the quranic affirmation, "[God] is with you wherever you are" (Q. 57:4). ${ }^{135}$ The shaykh also criticizes Kalām theologians for applying the verse, "No one knows its ta' will except God" (Q. 3:7), to God's descending, sitting and so forth. He says that this makes the prophets and the Salaf out not to have known what they were talking about when they mentioned these attributes. The second meaning of $t a^{\prime} w \bar{l} l$ is the linguistic inquiry or tafsir (interpretation or explanation) of early Qur'an exegetes such as Ibn 'Abbās (d. 68/687), Mujāhid (d. ca. 100-4/718-722) and al-Ṭabarī (d. 310/923). This is the $t a^{\prime}$ wil of the Salaf and "those firmly grounded in knowledge" (Q. 3:7). The third meaning of $t a^{\prime}$ will is the very reality of the thing referred to, as for example the existence of the various realities in Paradise. This is the ta'wìl that only God knows (Q. 3:7). Ibn Taymiyya puts God's attributes in this third category since only God knows their reality.

In Hamawiyya, the shaykh also cites the well-known statement of Mālik b. Anas on God's sitting: "The sitting is known, and the modality is unknown," and then interprets this as referring to his latter two types of $t a^{\prime}$ will:

The sitting is known (ma'lüm). Its meaning $\left(m a^{\prime} n \bar{a}\right)$ is known; it is interpreted (yufassar), and it is translated into another language. This is part of the $t a^{2} w i l$ that those firmly grounded in knowledge know. As for the modality (kayfyya) of this sitting, this is the $t a^{2}$ wil that only God-Exalted is $\mathrm{He}-$ knows. $^{136}$

134 The following discussion is based on Tadmuriyya, MF 3:55-8; Hamawiyya, MF 5:35-7;

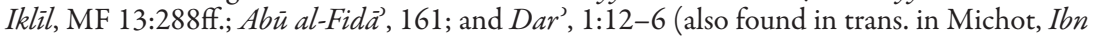
Taymiyya: Lettre à Abû l-Fidâ, 25-7). See also Ali, Medieval Islamic Pragmatics, 125-135; and al-Julaynad, Al-Imäm Ibn Taymiyya, 149-185, for further treatment of Ibn Taymiyya's approach to $t a^{\prime} w i \bar{l}$.

${ }_{135}$ Hamawiyya, MF 5:20, 96-7.

136 Hamawiyya, MF 5:36-7. Cf. Dar', 1:278. Several more brief passages in which Ibn Taymiyya interprets God's sitting are translated in Yahya M. Michot, "Textes Spirituels d'Ibn 
The level of $t a^{\prime} w i \bar{l}$ at which the shaykh works interpretively and theologically is the second, the linguistic level of tafsir and ascertaining the meaning. In Hamawiyya, Ibn Taymiyya's insistence that God's sitting means sitting, and not possessing as the Mu'tazilis would have it, leads him to reflect on the apparent contradiction between God's sitting on the Throne and His omnipresence found in "He is with you wherever you are" (Q. 57:4). The shaykh affirms that, just as God is with His creatures in reality (haqiqatan), $\mathrm{He}$ is on His Throne in reality, and, in an analysis based on the authority of Arabic semantic conventions, he explains that God's 'withness' (ma'iyya) consists in watching over His creatures and knowing them. He suggests that this might be as when someone says that the moon or stars are with him when traveling. Similarly, a father sitting on a roof may say to a son crying below, "Do not be afraid! I am with you." The father-son and moon-star images that Ibn Taymiyya provides are simply suggestions as to what Q. 57:4 may mean linguistically. However, interpretive maneuvers such as these were not well understood by Ibn Taymiyya's contemporaries and earned him the charge of anthropomorphism that led to his Damascene trials in 705/1306. ${ }^{137}$

In Hamawiyya, Ibn Taymiyya also attempts to reconcile God's sitting on the Throne with the hadith, "If one of you stands to pray, God is in front of his face. So, let him not spit in front of his face." ${ }^{138}$ Ibn Taymiyya explains that this is as when someone talks to the sky, sun or moon: they are over him and also, simultaneously, in front of his face. In this case, the shaykh finds precedent for his interpretive images in another hadith. He writes,

The Prophet-God bless him and give him peace-propounded the similitude in this. "To God is the highest similitude (al-mathal al-a'lä)" (Q. 16:60). However, what is meant by drawing a similitude (tamthil) is explanation of the permissibility (jawazz) of this and its possibility (imkān), not assimilation (tashbih) of the Creator to the creature. The Prophet-God bless him and give him peace-said, "There is not among you one but that he will see his Lord alone." Abū Razīn al-'Uqaylī said to him, "How is this, O Messenger of God, when He is only one and we are all together?" The Prophet-God bless him and give him peace-said, "I will inform you of the like (mithl) of this in the favors of God. This moon, each of you sees it alone, and this is a sign among the signs of God. God is greater," or as the Prophet-God bless him and give

\footnotetext{
Taymiyya: X. «Je ne suis dans cette affaire qu'un musulman parmi d'autres...»," Le Musulman (Paris) 23 (1994): 27-32 (at 28 n. 9).

${ }^{137}$ Hamawiyya, MF 5:103-4; and Munäzara, 3:177-8 (trans. in Jackson, "Ibn Taymiyyah on Trial," 71-2).

${ }_{138}$ Abū Dāwūd, 410, Al-Ṣalāt, Fī karāhiyyat al-buzāq fì al-masjid. Similar hadiths are found in Bukhārī, 391, and Muslim, 852.
} 
him peace-said. ${ }^{139}$ He said, "You will see your Lord as you see the sun and the moon." ${ }^{140} \mathrm{He}$ assimilated (shabbaha) the [one] vision to the [other] vision even if the [one] thing seen is not similar (mushäbih) to the [other] thing seen. When the believers see their Lord on the Day of Resurrection and talk to Him, each one will see Him over him in front of his face just as he sees the sun and the moon. There is no incompatibility fundamentally. ${ }^{141}$

On guard against anthropomorphism, Ibn Taymiyya prefaces his remarks in this quotation by noting that the hadith supplies a similitude that does not assimilate God to creatures. It only indicates what is permissible and possible with respect to God but not what exists necessarily in reality. The shaykh provides similar similitudes or interpretative images in his theodicean writings, especially in Minhāj, and these will be noted in Chapter Three. In methodological discussions examined next, Ibn Taymiyya links the verse, "To God is the highest similitude" (Q. 16:60), to a rational criterion for delineating the meanings of God's attributes and for deriving many of the attributes themselves.

\section{Giving God the Highest Similitude with the a fortiori Argument}

Up to this point, we have seen Ibn Taymiyya defend and explain an agnostic realism with respect to God's attributes on the authority of traditional sources. The attributes are real and meaningful, but their modality cannot be known, and this we know from tradition. However, he also believes that much of the same information concerning God's attributes is known by reason independently of revelation. The shaykh's rational proofs for God's complete unlikeness will be given toward the end of the following subsection; here it is sufficient to note that they are founded on his rigorous denial of extramental universals. The present subsection surveys his explanation and justification of the a fortiori argument as a rational tool for deriving and interpreting God's attributes of perfection. The following subsection then examines the shaykh's proofs for God's perfection from both revelation and reason, and it details several divine perfections.

139 Ibn Taymiyya's reporting of this hadith indeed appears to be very loose since I could not locate anything that closely resembles it. However, similar affirmations of the vision of God are found in Bukhārī, 521, Mawāqīt al-ṣalāt, Faḍl ṣalāt al-'aṣr; in Ibn Māja, 176, AlMuqaddima, Fīmā ankarat al-Jahmiyya; and elsewhere.

${ }_{140}$ The closest to what Ibn Taymiyya reports-but without mention of the sun-are alTirmidhī, 2477, Șifāt al-janna 'an rasūl Allāh, Minhu; and Ahmad, 18394.

141 Hamawiyya, MF 5:107. 
When discussing the methodology of theological argument, Ibn Taymiyya condemns the use of both analogy and categorical syllogism, and he explains that discussion of God's attributes and acts must occur in a fortiori mode. The shaykh is not adverse to analogy in legal matters. He traces the usage of legal analogy back to the Salaf and criticizes the Zāhirīs for rejecting it. ${ }^{142}$ The juristic analogy is invalid, however, if it contradicts what God has clearly legislated: "Wherever we know that the explicit text opposes an analogy, we know absolutely that it is an invalid analogy." ${ }^{143}$ In matters of theological doctrine, Ibn Taymiyya argues that the juristic analogy is always invalid because it brings God and creatures into a relationship of direct comparison. Even if God and an idol both happen to be objects of worship, and even if God and creatures share the fact of existence, these coincidences do not imply that God may be equated with created things in any other respect. Rather, God may not be made analogous to any created thing because of His incomparability. Drawing an analogy from a creature to God sets the two on the same level and is tantamount to idolatry. ${ }^{144}$

Turning now to the categorical syllogism, Ibn Taymiyya is well known for his polemic against Aristotelian logic, especially as it is found in his major work Kitāb al-radd' alā al-manțiqiyyin [Mantiqiyyin]. Wael Hallaq has provided a translation of Jahd, an abridged version of Mantiqiyyin, and, in his introduction, Hallaq shows that the shaykh's critique of the Aristotelian theory of definition and the categorical syllogism is extensive and incisive. ${ }^{145}$ For our purposes, however, it is important to note only two points. First, Ibn Taymiyya accepts the formal validity of the categorical syllogism (qiyass al-shumūl). However, he rejects the power of this syllogism to give certain knowledge, and he denies that the premises that philosophers, Kalām theologians and theosophical Sufis introduce into it are real universals. Universals for Ibn Taymiyya exist only in the mind. Thus, he believes, the elaborate metaphysical structures built up by Ibn Sīnā, Ibn 'Arabī, Fakhr al-Dīn al-Rāzī and many others exist only in the mind and not in external reality. ${ }^{146}$ Second,

142 Isfahāniyya, 79.

143 Qiyās, MF 20:505.

144 Qiyās, MF 20:541-2.

145 Hallaq, Ibn Taymiyya against the Greek Logicians. Jahd al-qarīha fì tajrìd al-nașiha is found in MF 9:82-254. The abridgement was carried out by Jalāl al-Dīn al-Suyūtī (d. $911 / 1505)$.

146 Hallaq, Ibn Taymiyya against the Greek Logicians, xiv-xxxii. Hallaq notes that qiyās al-shumu $\bar{l}$ is a rare expression for the categorical syllogism and may have been coined by Ibn Taymiyya himself (xiv, n. 17). He also explains that logic is simply superfluous for Ibn Taymiyya. Whatever knowledge it might provide can be obtained through simpler means including the natural constitution (xl; cf. Jahd, MF 9:187/Mantiqiyyin, 199-200; Jahd, 
in Jahd and elsewhere, the shaykh does not permit the use of the syllogism with respect to God because, as with the juristic analogy, it places God and creatures as different syllogistic terms on the same level. ${ }^{147}$

Although Ibn Taymiyya does not permit the univocal use of analogy and the categorical syllogism with respect to God, he does permit their use in a fortiori mode. Like analogy, the a fortiori argument plays an important role in Islamic jurisprudence. A common example of this argument concludes from the quranic injunction, "Do not say to [parents] 'Fie!"” (Q. 17:23), that hitting parents is a fortiori (i.e. all the more) prohibited because the disrespect shown to parents in hitting is all the worthier of being prohibited than the disrespect shown in saying "Fie!" 148 When applied to God, this argument, in Ibn Taymiyya's view, maintains the necessary unlikeness between God and creatures and, moreover, asserts that God is all the worthier (awlä) of whatever judgment of perfection is applied to creatures than are the creatures themselves. He explains this as follows:

Sometimes, the common degree (qadr mushtarak) in a rational argument is considered without consideration of priority (awwaliyya), and sometimes priority is considered in it. The a fortiori argument (qiyass al-awlä) is composed in this [latter] way. This [obtains] if it has been made a kind of categorical syllogism or analogy having a particular [characteristic] by which it is distinguished from all [other] kinds, which is that the desired judgment be worthier of being established than is the case mentioned in the proof proving it.

This type is what the Salaf and the Imāms-like Imām Ahmad and others among the Salaf-followed with respect to rational proof in the matter of

217-8/Mantiqiyyin, 293-8). In this regard, according to Hallaq, Ibn Taymiyya argues that the categorical syllogism differs only in form from the juristic analogy. The two are in fact interchangeable because the middle term of the syllogism is equivalent to the cause and shared attribute of the analogy. For example date wine (nabidh) has been prohibited by analogy to grape wine (khamr) whose assessment or rule $(\mathrm{hukm})$ of prohibition has been set down in the authoritative sources of the Qur'an and the Sunna. Through a process of induction, the jurists determine that the cause ('illa) of this rule is intoxication even though it is not given in the texts. Now, since intoxication is a common attribute (wasf mushtarak) between grape wine and date wine, the rule of prohibition also applies to date wine. The prohibition of date wine may also be set out syllogistically as follows. All intoxicants are prohibited (major premise). Date wine is intoxicating (minor premise). Therefore, date wine is prohibited (conclusion). In this case, the middle term 'intoxicants' is equivalent to the cause and common attribute in the analogy. The rule of prohibition that attaches to intoxicants establishes both the major premise of the syllogism and the analogical transfer of the ruling from grape wine to all other intoxicants (xxxv-xxxix; cf. Nubuwwät, 270-3; Kayläniyya, MF 12:345-7; Isfahäniyya, 48; and Jahd, MF 9:197-206/Mantiqiyyin, 209-246).

147 Jahd, MF 9:141-2/Manțiqiyyīn, 150; Tadmuriyya, MF 3:30; Kayläniyya, MF 12:347; and Isfahäniyya, 49.

148 Wael B. Hallaq, A History of Islamic Legal Theories: An introduction to Sunnī uṣūl alfiqh (Cambridge, UK: Cambridge University Press, 1997), 96-9. 
[God's] lordship, and it is what the Qur'an brought. This is because it is not admissible that God-Exalted is $\mathrm{He}$ - and another be included in a categorical syllogism whose terms are on the same level or in an analogy in which the judgment of the original case and that of the assimilated case are on the same level. Indeed, God-Exalted is $\mathrm{He}$-there is nothing like Him neither in His essence (nafs) which is mentioned through His names, nor in His attributes, nor in His acts. However, the a fortiori argument is followed with respect to Him. As He said, "And to God is the highest similitude (al-mathal al-a'lā)" (Q. 16:60).

[Concerning] every perfection and attribute praiseworthy in itself and devoid of imperfection that belongs to some created, originated existents, it is known that the Lord, Creator, Self-Subsistent (Samad), Everlasting (Qayyüm), Eternal and Necessary Existent in Himself is all the worthier of it. And [concerning] every imperfection and defect from which some originated, possible creatures must be exonerated, the Lord, Creator, Holy, Peace, Eternal, Necessary of Existence in Himself is all the worthier of being exonerated from it. ${ }^{149}$

Analogies and categorical syllogisms may not be employed univocally for God. Rather, the a fortiori argument which maintains God's unlikeness should be used, and, following the quranic verse, "For God is the highest similitude" (Q. 16:60), God should be given the highest similitude or likeness (mathal). This entails attributing all creaturely perfections to God and freeing Him from every creaturely imperfection because He is a fortiori worthy of being so qualified. Ibn Taymiyya asserts furthermore that the a fortiori argument has a venerable tradition in the Qur' an and among the Salaf and other important leaders of the Islamic community such as Ibn Hanbal.

I have not found the shaykh showing how the Salaf and Ibn Hanbal use the a fortiori argument. ${ }^{150}$ In Dar' however he does furnish some examples

149 Isfahāniyya, 49. For the same arguments, see also Dar', 1:29-30, Tadmuriyya, MF 3:30; and Kaylāniyya, MF 12:347.

${ }^{150}$ Ibn Hanbal uses the highest similitude argument in a passage in Al-Radd' alā zanādiqa wa al-Jahmiyya, ed. Muhammad Hasan Rāshid (Cairo: al-Maṭba'a al-salafiyya, 1393/1973-4), 37, which Ibn Taymiyya quotes in Minhäj, 2:484-5/1:234, for other purposes. In response to the Jahmī charge that the traditionalists deny God's unity by affirming His attributes, Ibn Hanbal compares God to a palm tree. The palm tree has a stump, leaves and so forth, but yet it is considered one in name. "So, likewise, God-for Him is the highest similitude-with all His attributes is one God." Immediately following this, Ibn Hanbal gives a second example, this time from the Qur'an: "Leave Me [to deal] with him whom I have created one (wabid)" (Q. 74:11). Ibn Hanbal takes the one created to be al-Walìd b. al-Mughīra al-Makhzūmī who despite being called "one" still had ears, eyes and other body members. From this Ibn Hanbal concludes, "So, likewise, God-for Him is the highest similitude-He, with all His attributes, is one God." I have not here followed the unclear translation of Ibn Hanbal's Radd found in Morris S. Seale, Muslim Theology: A Study of Origins with Reference to the Church Fathers (London: Luzac, 1964), 96-125 (specifically 116-7). Wesley Williams, "Aspects of the Creed of Imam Ahmad Ibn Hanbal: A Study of Anthropomorphism in Early Islamic 
of the a fortiori argument in the Qur'an. He gives two sets of arguments, first providing proofs for the resurrection at the Last Day and second giving proofs for God's exoneration from having associates. ${ }^{151}$

Concerning the resurrection, Ibn Taymiyya begins by explaining that we know the possibility of something existing in the extramental world either by its actual existence, by the existence of something equivalent to it, or by the existence of something greater. In the latter case, "The existence of something is a proof that something below it is a fortiori possible." 152 Moreover, the existence of any possibility is contingent upon the Lord having power to make it occur. Ibn Taymiyya then cites quranic verses pointing to the original creation of the heavens and the earth, as well as of humans, to demonstrate a fortiori God's power to raise humankind again. These include, "It is $\mathrm{He}$ who begins the creation, and then brings it back again, and this is easier for Him. To Him is the highest similitude in the heavens and the earth" ( $Q$. 30:27), and, "Do they not see that God Who created the heavens and the earth is powerful to create the like of them" (Q. 17:99). However, the shaykh devotes the most attention to several verses in Sürat Yā Sīn:

He set forth a similitude and forgot His creation. He said, "Who will give life to these bones when they are decayed?" Say, "He will give life to them Who brought them forth the first time! He is All-Knowing about every creation. He who makes fire for you out of the green tree. Behold, from it you kindle." Is not $\mathrm{He}$ Who created the heavens and the earth powerful to create the like of them? Yes, indeed! He is the Supreme Creator, the All-Knowing (Q. 36:78-81).

The shaykh points out that the question, "Who will give life to these bones when they are decayed?" is rhetorical, inviting the response that no one can give life to decayed bones. However, the Qur'an then underlines that this is indeed possible for God by pointing to His original creation of life from dust: "He will give life to them Who brought them forth the first time." Then with the statement, "He who makes fire for you out of the green tree," the Qur'an shows that God produces hot dry fire from what is cold and moist, something even more difficult than bringing life out of decayed

Discourse," International Journal of Middle East Studies 34 (2002): 441-463, confirms that Ibn Hanbal engages in more interpretation and rational theological argument than is commonly acknowledged. Williams also shows that Ibn Hanbal is fully an anthropomorphist (mushabbib) who makes no effort to deny that the modality (kayf) of God's attributes can be known. In this respect, Ibn Taymiyya does not follow Ibn Hanbal.

${ }^{151} \mathrm{Dar}^{\prime}, 1: 31-7$. Isfahaniyya, 86, includes a much briefer demonstration of the a fortiori argument in the Qur'an, citing only Q. 16:58-62 and 30:28, which will figure also in the following discussion.

152 Dar $^{\prime}, 1: 32$. 
bones. Thus, the formation of living beings from decayed bones is a fortiori possible, and the God who can create fire from a green tree is a fortiori able to create life from dust. ${ }^{153}$

The second set of a fortiori arguments Ibn Taymiyya cites from the Qur'an in Dar' show God's freedom from associates. These arguments are of two kinds. In the first, the belief of pre-Islamic idolaters that God had daughters while they themselves disliked having daughters is shown to be absurd. If having daughters is judged to be an imperfection in the human sphere, God is all the worthier of being exonerated from this imperfection. Following is one of the quranic passages that the shaykh uses to illustrate this argument:

And they assign daughters to God-Glory be to Him — and to themselves what they desire. When one of them is given the news of a girl, his face becomes dark, and he chokes inwardly. He hides himself from the people because of the evil of the news that has been given him. Shall he keep her with dishonor or bury her in the earth? Certainly, evil is their decision. For those who do not believe in the hereafter is a similitude of evil, and for God is the highest similitude. And $\mathrm{He}$ is All-Mighty, All Wise... They assign to God what they hate, and their tongues assert the lie that better things will be theirs. Without doubt, theirs will be the Fire, and they will be hastened into [it] (Q. 16:57-62).

Ibn Taymiyya concludes from this passage and two others (Q. 43:16-9 and 53:19-23) that God has made it obvious that $\mathrm{He}$ is far worthier of being exonerated of imperfections than humans. It is not permissible for humans to attribute to God what they hate to attribute to themselves. ${ }^{154}$ This is apparently so even when the value system sustaining the argument-dislike of daughters and female infanticide-is denounced in the process of argumentation.

The same point lies behind a second kind of quranic argument showing God's a fortiori freedom from associates. Ibn Taymiyya cites the verse, "He set forth a similitude for you from yourselves. Do you have, among what your right hands own, associates in what we have provided for you so that you are equal with regard to it, you fearing them as you fear each other?" (Q. 30:28). According to the shaykh, God is here explaining that humans do not permit what they own, that is, their slaves, to be associates with them in their property such that they would fear their slaves as they fear their peers. Then, God is asking humans how they could make His slaves and His creatures associates with Him. The implication is that God is a fortiori

153 Dar', 1:31-5.

154 Dar', 1:35-7. 
worthy of being exonerated of associates that humans do not permit even for themselves. 155

With the above examples, Ibn Taymiyya shows that the type of theological argumentation found in the Qur'an is a fortiori and that this establishes the permissibility of arguing in this mode in theological matters. In the shaykh's view, the a fortiori argument preserves the unlikeness between God and creatures which univocal use of analogy and syllogism fails to respect. Moreover, the last two arguments cited above-God's a fortiori right not to have daughters and associates-illustrate the principle that God must be given the highest similitude. That is, the Qur'an stipulates that God has an a fortiori right to be ascribed with perfections found in creatures and exonerated of all creaturely imperfections. This style of reasoning guarantees that God is spoken well of and in praiseworthy fashion without making Him like creatures.

\section{Affirming God's Attributes of Perfection and Praiseworthiness}

Ibn Taymiyya maintains that God's perfection (kamäl) is known by reason and the natural constitution on the one hand and revealed tradition on the other. ${ }^{156} \mathrm{He}$ combines arguments from both streams in his lengthy fatwa Akmaliyya, which also provides a fairly complete overview of God's attributes of perfection. Much, but not all, of what follows here comes from this fatwa. Although the philosophical term 'perfection' is not used with reference to God's attributes in the Qur'an, Ibn Taymiyya claims that the Qur'an indicates its meaning in mentioning God's praiseworthiness, in giving God "the highest similitude" (Q. 16:60), and in establishing God's names. The shaykh also reports that the Qur'an exegete Ibn 'Abbās interpreted the divine name Self-Subsistent (al-Samad) found in Surat al-Ikhlās (Q. 112) to mean that God has the right to perfection. ${ }^{157}$

Some of the shaykh's quranic support for God's perfection has already been cited above as examples of the a fortiori argument (Q. 16:57-62 and Q. 30:28). A few more examples follow here. The verse, "Is then He who creates as one who does not create? Do you not remember?" (Q. 16:17), shows that creating is an attribute of perfection and that the Creator is better than the creature. Another verse illustrates that being an impotent slave is an attribute

55 Dar', 1:37.

156 Akmaliyya, MF 6:71-3; and Jawāb, 3:220.

157 Akmaliyya, MF 6:71-3. Cf. Nuzūl, 5:229. On the name al-Ṣamad see also Ikblās, MF 17:214-221; and Irāda, MF 8:149-150. 
of imperfection while power, sovereignty and beneficence are attributes of perfection: "God propounded a similitude: a servant owned by another who has no power to do anything and one to whom We have provided a good provision from Us and who spends from it secretly and openly. Are they equal? Praise belongs to God, but most of them know not" (Q. 16:75). Ibn Taymiyya also cites Abraham's question to his father, "O my father! Why do you worship that which does not hear, does not see and cannot avail you anything?" (Q. 19:42), to show that hearing, seeing and availing are attributes of perfection and to illustrate that the Qur'an often describes idols as devoid of perfections such as speech, life, action and so forth. ${ }^{158}$

In addition to the Qur'an, Ibn Taymiyya bases the attributes of perfection in reason and the natural constitution. He says that it is known by the natural constitution necessarily that God is more perfect than anything else just as it is known that $\mathrm{He}$ is the Creator. ${ }^{159}$ Similarly, the shaykh argues that God's right to perfections that are completely devoid of imperfection, as well as His right to freedom from all imperfection, is known by reason necessarily and "in the bases of intellects ( $f_{i}$ bidayat al'uqül)." He grounds this in two separate but related principles. First is causal priority. A cause is known necessarily to be more perfect than the effect; the Creator is more perfect than the creature; the Eternal is more perfect than the temporal; and the Necessary Existent is more perfect than the possible that is susceptible to nonexistence. Second, God is the source of all perfections found in creatures. God is the Creator of every existent belonging to the creature, and creatures derive (istafäda) all of their perfections from their Lord and Creator. An imperfect creature cannot create a perfect existent, and so all perfection must ultimately depend upon God. On both grounds, God is a fortiori worthy of all perfections found in creatures. The Creator is all the worthier of any perfection found in the creature because He is more perfect than the creature and because He is the very source of the creature's perfection. As Ibn Taymiyya sees it, creatures are worthier of the imperfections of nonexistence, possibility and origination. ${ }^{160}$

Ibn Taymiyya makes extensive use of the disjunctive reasoning indigenous to Kalām theology to establish the various attributes of perfection rationally. Accordingly, diverse attributes must be ascribed to God because the contraries would render Him imperfect. For example, the shaykh says that reason

158 Akmaliyya, MF 6:72-3, 79-82.

159 Akmaliyya, MF 6:72-3; and Isfahäniyya, 87-8.

160 Dar', 1:29-30; Isfahāniyya, 85-6; Akmaliyya, MF 6:75-7; and Jawāb, 3:215-6. 
knows necessarily that hearing and sight are attributes of perfection because a living being who can see and hear is more perfect than one who cannot. Similarly, one who is living and knowing is more perfect than one who is not. Moreover, God must be qualified as hearing and seeing lest $\mathrm{He}$ be imperfect and dependent upon another. If God were not qualified with hearing and seeing, hearing and seeing creatures would be more perfect than $\mathrm{He}$ is, and He would not be worthy of worship. ${ }^{161}$ In another example the same logic applies to God's life. If God were not qualified with life, an attribute to which He has an essential right, he would be dead, and living creatures would be more perfect than He would be. ${ }^{162}$ The following text provides a reasonably comprehensive sample of such disjunctive reasoning:

If [God] were not living, knowing, hearing, seeing and speaking, it would necessarily follow that $\mathrm{He}$ is dead, ignorant, deaf, blind and mute. He must be exonerated of these imperfections. Indeed, $\mathrm{He}-$ Glory be to $\mathrm{Him}$ - has created whoever is living, hearing, seeing, speaking, knowing, powerful and moving (mutaharrik). So, He is all the worthier to be like that. Indeed, every perfection in a caused, created thing is from the perfection of the Creator. ${ }^{163}$

While Kalām theologians often prove God's attributes in like fashion, they would not include movement as we find in this text. They would typically reinterpret this and other alleged anthropomorphisms such as God's descending and coming that appear in the Qur'an and the Sunna. Ibn Taymiyya however argues that if God could not move He would be inferior even to inanimate objects. Such objects are at least subject to being moved by another. Moreover, if God could move but did not, then He would be inferior to objects that do move on their own initiative. Rather, a living being is moving and active by itself. ${ }^{164}$

Ibn Taymiyya also provides arguments to prove and explain the perfection of God's other seemingly anthropomorphic attributes. For example, God is qualified with laughter to exclude crying and with joy to exclude sadness. Crying and sadness entail weakness and impotence that are not fitting for God. ${ }^{165}$ Joy also appears in another argument. One who loves, rejoices and is well pleased with attributes of perfection and who hates imperfection such as injustice and ignorance is more perfect than one who does not differentiate between perfection and imperfection. Thus, love, joy, good pleasure and

\footnotetext{
161 Isfahāniyya, 85, 87-8.

162 Jawāb, 3:208-9, 211.

163 Qudra, MF 8:21. For similar argumentation, see Jawāb, 3:217.

164 Qudra, MF 8:22-4.

165 Tadmuriyya, MF 3:86-7.
} 
hate are among God's attributes of perfection. One who has power to act by his hands is more perfect than one who does not because the former can choose to act with his hands or through some other means whereas the latter does not have the option of using his hands. By implication, God's hands are among His attributes of perfection. ${ }^{166}$

Exonerating God of certain imperfections poses slightly more difficulty for Ibn Taymiyya. He admits that it is true that living beings that eat and drink are more perfect than those that are sick and do not eat and drink. This is because their sustenance depends upon eating and drinking. Nonetheless, the creaturely perfections of eating and drinking are not completely free of imperfection because they imply need, that is, need for food and drink. Now, one who does not need to take anything into himself and is not dependent on something outside himself is more perfect than one whose perfection consists in eating and drinking. Thus, eating and drinking are not among God's attributes of perfection. ${ }^{167}$ Ibn Taymiyya argues that even the angels do not eat and drink. Thus, God a fortiori does not eat and drink since God is all the worthier of whatever perfections are found in creatures, in this case the angels. Moreover, the shaykh adds, God's not eating and drinking is confirmed by the revealed tradition through God's name Self-Subsistent (al-Samad). ${ }^{168}$

Ibn Taymiyya also asserts that the perfection of God's attributes entails their unlikeness to created things: "[God] is qualified by every attribute of perfection such that no one bears any likeness to Him in it." ${ }^{169}$ Paradoxically, this means that God must be qualified with the highest conceivable perfection and that the perfection of that perfection is to be completely unlike any created thing. In his Tadmuriyya creed, the shaykh supports the unlikeness of God's attributes with a number of a fortiori arguments rooted in his thoroughgoing nominalism and rejection of real universals.

In one of these arguments, Ibn Taymiyya observes that the revealed sources describe numerous things in Paradise such as foods, clothes, dwellings, marriage and so on. To this he adds a saying of Ibn 'Abbās, "There is nothing in this world that is in Paradise except the names." ${ }^{170}$ Ibn Taymiyya then argues that, if there is such a great distinction between the realities of Paradise and

\footnotetext{
166 Akmaliyya, MF 6:92-3.

167 Akmaliyya, MF 6:87.

168 Tadmuriyya, MF 3:86.

169 Tadmuriyya, MF 3:74.

170 Tadmuriyya, MF 3:28.
} 
the realities of this world such that they share only the names given them, the distinction between God and created things must be even greater. ${ }^{171}$

In a second argument, Ibn Taymiyya outlines the difficulty of pinning down what it means for the human spirit $(r \bar{u} h)$ to be powerful, hearing, ascending at death and so on. Although we qualify the spirit with such attributes, we cannot investigate its modality because we cannot see it. Thus, the shaykh concludes, "If the spirit is qualified with these attributes, but without their likeness to what is seen of created things, then the Creator is all the worthier of His distinction from His creatures while being qualified with $\mathrm{His}$ names and attributes that $\mathrm{He}$ deserves." ${ }^{172}$

In a third argument from Tadmuriyya, Ibn Taymiyya states, "If the creature is exonerated of likeness to [another] creature despite concordance in name, then the Creator is all the worthier of being exonerated from likeness to a creature even if there is concordance in name." ${ }^{173}$ It may appear gratuitous to presuppose that creatures bear no likeness (mumäthala) one to another except in name. This is not explained in its context in Tadmuriyya, but it fits with Ibn Taymiyya's thoroughgoing rejection of the extramental status of universals. ${ }^{174}$

Although Ibn Taymiyya maintains that the modalities of God's attributes are completely unlike those of creatures except for the names, he occasionally ascribes a certain religious function to God's attributes and acts by claiming that a God without this or that attribute or act is not worthy of worship ('ibäda) or praise ( hamd). As noted in passing above, for example, Ibn Taymiyya maintains that a God who cannot see and hear is not worthy of worship. Similarly, he writes, "It is firmly established in natural constitutions that that which does not hear, see or speak is not a lord who is worshipped. Similarly, that which does not avail anything, does not guide and does not possess any harm or benefit is not a lord who is worshipped." ${ }^{175}$ Elsewhere, the shaykh argues that a God who does not love has no right to be worshipped, and in the theodicean text Hasana he states that a God who does not act with mercy and wise purpose is not worthy of praise. ${ }^{176}$ Such assertions may suggest that God should be praised and worshipped on account of His attributes and acts. To draw this conclusion however would be misleading.

\footnotetext{
171 Tadmuriyya, MF 3:28. Cf. Ikhlās, MF 17:325-6 and Hamawiyya, MF 5:115.

172 Tadmuriyya, MF 3:33. Cf. Hamawiyya, MF 5:115-6.

3 Tadmuriyya, MF 3:30.

174 On this see Hallaq, Ibn Taymiyya against the Greek Logicians, xxii.

175 Isfahāniyya, 87.

176 'Alaq, MF 16:296-7; and Hasana, MF 14:313.
} 
In Akmaliyya, Ibn Taymiyya explains the religious function of God's attributes more fully. He observes that God's attributes of perfection are not mentioned in the Qur'an merely to counter those who strip them away ( $a b l$ $a l-t a t i t l)$. It also enumerates them to show God's right to worship, especially against the associationists (mushrikün): "God-Glory be to Him-did not mention these texts only to confirm the attributes of perfection for Him. Rather, He mentioned them to make evident (li-bayann) that He has the right to worship apart from any other." 177 The shaykh further notes that there are two kinds of praise (hamd) due to God:

Praise is of two kinds: [1] praise for His beneficence to His servants, which belongs to giving thanks; and [2] praise for that to which He has a right in Himself $(b i-n a f s i b i)$ with respect to the attributes of His perfection. This praise is only for what He in Himself has a right to praise. Only one who is ascribed with attributes of perfection, which are existing things (umür wujūdiyya), has a right to that. There is no praise, good or perfection in purely nonexisting things. ${ }^{178}$

With this, it becomes clear that God is praised not only for what He does but also for who He is in His very self (nafs), and, as indicated in the text, Ibn Taymiyya links God's attributes very intimately to God's self or essence $(d h \bar{a} t)$. He explains later in Akmaliyya that a perfect essence without attributes of perfection is impossible and that it is known necessarily that an essence ascribed with such attributes is more perfect than one without. These attributes are necessary concomitants (lawãzim) of God's essence, without which the essence would not exist. Thus, mentioning God's attributes of perfection is tantamount to mentioning His essence. ${ }^{179}$ In Akmaliyya, Ibn Taymiyya is not as clear as he could be that worship and praise of God for His essence and the concomitant attributes of perfection takes priority over praise of God for His acts, but as we have seen earlier in this chapter, God's divinity-God's right to worship in Himself-takes precedence over God's lordship and acts. God should be worshipped first for who He is and only secondarily for what He does, and the role of God's attributes of perfection is to make evident God's essential right to praise and worship. This religious function of God's attributes increases the gravity of Ibn Taymiyya's juridical search for the best way to speak about God.

177 Akmaliyya, MF 6:83.

178 Akmaliyya, MF 6:84.

179 Akmaliyya, MF 6:95-7. For other assertions of the necessary concomitance of God's attributes with His essence, see Hamawiyya, MF 5:26; MF 5:206; Nuzül, MF 5:326; MF 12:46; and Isfahäniyya, 49. 


\section{The Apologetic Quality of Ibn Taymiyya's Theological Jurisprudence}

We are now in position to characterize Ibn Taymiyya's theological fiqh more precisely. For the shaykh, both reason and revelation yield knowledge of God's existence and basic human ethical ends, especially that God alone should be worshipped. One aspect of worship is speaking correctly about God, and the task of Ibn Taymiyya's theological jurisprudence is to ascertain how to do this. The shaykh explains that both reason and revelation specify that God is ascribed with attributes of perfection and praiseworthiness. As for revelation, the Qur'an and the Hadith indicate God's attributes; the views of early Qur'an exegetes and the conventions of the Arabic language delineate the linguistic meanings of these attributes; and similitudes are used to suggest possible resolution of rational difficulties that may arise. Moreover, God's attributes are ontologically real, but on the basis of "There is nothing like Him" (Q. 42:11) their modalities are entirely unknown. As for reason, Ibn Taymiyya employs a fortiori argumentation to build a kind of natural theology that takes human perfection as its point of departure for defining God's perfection while exonerating God of neediness and creaturely modalities. As the shaykh sees it, this is likewise the kind of theological reasoning found in the Qur'an, finding specific support in the verse, "To God is the highest similitude (al-mathal al-álä)" (Q. 16:60).

Although Ibn Taymiyya claims that independent reason or the natural constitution, exercised without corrupting influences, will arrive at correct theological doctrine, it is perhaps going too far, as I do above, to speak of the shaykh building a natural theology. Rather, it seems clear enough that he is devising his rational arguments so as to arrive safely at theological doctrines held a priori on the basis of the authoritative tradition. With this in mind, the methodology of Ibn Taymiyya's theological jurisprudence may be characterized more analytically as a two step process. The first step is more properly theological. The shaykh seeks to determine what should be said about God from the Qur'an and the Hadith, and he employs philosophical concepts or models-similitudes - to elucidate the sense and coherence of his ordinary language reading of these sources. The resulting theological vision is that of a dynamic God who is far more engaged in the vicissitudes of human life and the historical process than the God of the philosophers and the Kalām theologians but who is in no way conflated with the created world as the shaykh understands the God of Ibn 'Arabì to be. This unique concept of God provides the theological framework from within which Ibn Taymiyya compares and critiques rival theologies. 
The second step is apologetic. Ibn Taymiyya makes and seeks to demonstrate the claim that his theological vision is that of both tradition and reason, which agree and confirm each other. He attempts to show that his reading of the Qur'an and the Hadith follows the intentions of the Salaf, accords with the conventions of the Arabic language and ascribes to God the highest praise and perfection. Likewise, he asserts that this doctrine is known by independent reason properly exercised and that such reasoning is the kind found within revelation. With this, the shaykh seeks to claim the rational high ground over against the Kalām theologians and Muslim philosophers on behalf of his tradition-based theological vision. He resists intellectual currents that each in their own way drift toward elitism and esotericism, either elevating reason over revelation on the one hand (Kalām theologians and especially philosophers) or subordinating reason to mystical experience on the other (Ibn 'Arabī). Thus, Ibn Taymiyya commends his theological vision as both faithful to the revealed tradition and publicly available to all right thinking people.

In short Ibn Taymiyya's juridical work on how to speak of God is theological in both the sense that it has to do with God and in the sense that it seeks to explore the rationality and coherence of theological doctrine derived from revelation. It is apologetic in that it makes a claim not only on those who accept revelation fideistically but on all persons of sound intellect, even those without access to revelation. Thus, Ibn Taymiyya's methodology may be characterized most precisely, albeit awkwardly, as apologetic theological jurisprudence.

The remainder of this study examines how Ibn Taymiyya interprets Islamic doctrine concerning the metaphysical and moral relationship between God and His creatures and how he faces rational difficulties that arise concerning purposeful creation and God's self-sufficiency, human responsibility and God's determination, and evil and God's justice. Ibn Taymiyya could take these diverse conundrums as keys to esoteric knowledge; or he could protest that God's ways with humankind appear unjust and irrational; or he could abandon obedient worship of God altogether. But he does none of these. At a number of points along the way, it becomes evident that his understanding of God's essential right to perfection and his apologetic aims impede giving voice to paradox, protest or skepticism. In this light, Ibn Taymiyya's theodicy comes into view as a valiant juristic effort to find the best way to give God the highest praise in the face of seemingly intractable rational dilemmas. 
CHAPTER TWO

\section{GOD'S WISE PURPOSE, PERPETUAL ACTIVITY AND SELF-SUFFICIENCY}

\section{The Problematic of God's Goodness and God's Self-Sufficiency}

In order to safeguard God's sufficiency apart from the world, Ash'arī Kalām theologians deny that God wills to create the world on account of causes or wise purposes. There is no reason why God created the world in time out of nothing when He did, and God does not need the world to be God. Mu'tazili Kalām theologians agree that God has no need for the world and that He created the world ex nibilo. Nonetheless, the Mu'tazilis try to affirm a stronger sense of God's goodness by introducing some kind of rationality into creation. God created the world to benefit humankind, but God's wise purpose in creation has no impact on Him.

Ibn Taymiyya follows neither the Ash'arīs nor the Mu'tazilīs on the issue of God's sufficiency apart from the created world. Instead, he affirms that God creates for the sake wise purposes that God loves, and, to make sense of this, he employs conceptual strategies found also in Ibn Sinnā. A review of some of Ibn Sināss basic ideas here will prepare the ground for further consideration of Ibn Taymiyya's approach in the rest of the chapter.

Within Ibn Sināss writings is found a view of God's unchanging perfection not unlike that of the Kalām theologians. God is completely perfect as $\mathrm{He}$ is. He is pure perfection, pure good and pure actuality. God has no need, and there is no unrealized potentiality or possibility in God. God does not change because change would entail imperfection in God. ${ }^{1}$ However, Ibn Sinā rejects the Kalām doctrine of creation ex nibilo and portrays the creation of the world as an emanation proceeding necessarily from its First Cause God. God is essentially productive, emanating the world as a necessary concomitant of His essence. The world is eternal because its Cause is

\footnotetext{
${ }^{1}$ Ibn Sīnā, "Al-Risāla al-'arshiyya fì tawhīidihi ta ālā wa șifātihi," in Majmư rasā̄il al-Shaykh al-Ra'ìs Abì Alī al-Husayn b.'Abd Allāh b. Sinnā al-Bukhārì, (Haydarābād al-Dakkan: Maṭba'at jam 'iyyat dā’irat al-ma ārif al-'uthmāniyya, 1354/1935-6), 5; Ibn Sīnā, Al-Mabdả wa al-máād, 10-11; Ibn Sīnā, Al-Shifằ: Al-Ilāhiyyāt (2), 356; and Ibn Sīnā, Al-Táliquàt, ed. 'Abd al-Rāḥmān Badawī (Cairo: Al-Hay’a al-miṣriyya al-āmma li-l-kitāb, 1973), 21, 102-3, 150. 
eternal. Ibn Sīnā also rejects the Mu'tazili claim that God creates the world for the good of creatures. God does not emanate the world out of concern for the world itself, nor does God act for causes or purposes external to Himself because that would entail change in God. ${ }^{2}$ Instead the emanation of the world follows necessarily from the very essence of God. Ibn Sinā puts it this way: "The emanation of things from [the Creator] is because of His essence, not because of something external, and His essence is the cause of order and good."’ Ibn Sinna speaks about the origin of the world in a variety of idioms. For example, he speaks of the First's (i.e. God's) love ('ishq) of Itself: "When the First loves Its essence because It is good and Its beloved essence is the principle of existing things, then they emanate from It ordered in the best order." ${ }^{\prime \prime}$ Another idiom is the First's knowledge of Itself. The First does not acquire knowledge from existing things but from Its essence, and Its knowledge is then the cause of existing things: "The First knows everything from Its essence, not that existing things are a cause of Its knowledge, but Its knowledge is a cause of them.".5

Al-Ghazālī takes Ibn Sīnā and his ilk to task for denying the agency and will of God despite their claims that God is the Artisan and Agent of the world. ${ }^{6}$ While Ibn Sinā does speak of God willing and choosing to create the world, he does so only in a certain sense. The philosopher equates God's will (iräda) with God's knowledge or God's providence and insists that God's will is not subject to purpose in the Mu'tazilī sense. ${ }^{7}$ Rather, God's choice is conformity with His essence:

In the choice (ikbtiyarr) of the First, no motive motivates It to [exercise] that [choice] other than Its essence and Its goodness. It does not have choice potentially and then become one who chooses actually. Rather, It has been eternally choosing in actuality. Its meaning is that It does not choose other than what It does. ${ }^{8}$

2 Ibn Sīnā, Al-Ishārāt wa al-tanbīhāt, 3:147-151; Ibn Sīnā, Al-Táliquāt, 16, 53-54, 159; and Ibn Sīnā, Al-Mabda' wa al-máād, 33.

${ }^{3}$ Ibn Sinnā, Al-Táliqät, 159.

${ }^{4}$ Ibn Sīnā, Al-Táliquàt, 157.

5 Ibn Sīnā, Al-Táliqāt, 192. Cf. Ibn Sīnā, "Al-Risāla al-'arshiyya," 9.

6 Al-Ghazālì, The Incoherence of the Philosophers, Arabic ed. of Tahäfut al-faläsifa and trans., Michael E. Marmura (Provo, UT: Brigham Young University Press, 1997), 56-78 (Third Question).

7 Ibn Sīnā, Al-Shifä̀: Al-Ilāhiyyāt (2), 366-7; Ibn Sīnā, "Al-Risāla al-'arshiyya," 10-11; Ibn Sīnā, Al-Mabdà wa al-máād, 20-21; and Ibn Sīnā, Al-Táliquāt, 19, 71-2, 80, 117.

${ }^{8}$ Ibn Sīnā, Al-Táliqāt, 50-51. 
Here as with God's knowledge and God's love, any thought that God needs the world as an arena in which to manifest His attributes or carry out His will is eliminated by making God's essence the first point of reference. God's self-referentiality is essential while the world that emanates eternally from the essence is only accidental. As Ibn Sinā puts it, "[The First] loves Its essence.... and the order of the good is beloved to It accidentally (bi-l'arad)." God loves, wills, knows and chooses only Himself in the first instance. God has no need of the world, and He does not love or will it directly. The world only emanates from God as an accidental, but necessary, concomitant of God's self-love and self-willing. ${ }^{10}$

As will become apparent below, Ibn Taymiyya resolves the problem of relating God's self-sufficiency to God's goodness in creating the world with the notions of God's self-love and God's necessary, but accidental, creative work in a fashion similar to that of Ibn Sinā. However, the shaykh departs substantially from Ibn Sinā by rejecting emanation and giving a much stronger and more dynamic role to God's will.

\section{Joseph Bell on God's Wise Purpose and Self-Sufficiency in Ibn Taymiyya's Theology}

Joseph Bell gives extended attention to Ibn Taymiyya's theology of God's wise purpose and God's sufficiency in his Love Theory in Later Hanbalite Islam. In line with the book's title, Bell's primary interest is Ibn Taymiyya's doctrine of love, especially in dialogue with Ash'arī theology. The Ash'arīs maintain that God cannot love humans and humans cannot love God. Otherwise, God would suffer need, and God would share some measure of affinity with human beings. They also argue that the eternal God cannot be an object of human love because only a nonexistent or something susceptible to nonexistence can be loved. Henri Laoust attributes this view to Ibn Taymiyya as well, arguing that the shaykh taught love for God's law

\footnotetext{
9 Ibn Sin̄ā, Al-Shifä̀: Al-Ilāhiyyāt (2), 363.

${ }^{10}$ For further exposition, see Rahim Acar, Talking about God and Talking about Creation: Avicenna's and Thomas Aquinas' Positions (Leiden: Brill, 2005), 132-149; which is nearly identical to Rahim Acar, "Avicenna's Position Concerning the Basis of the Divine Creative Action," The Muslim World 94 (2004): 65-79. Ibn Sināss view of God's creation of the world has often been portrayed as naturalistic-like fire burning - rather than volitional. Acar shows that this is inaccurate and interprets Ibn Sinnäs view of creation along lines compatible with what I present here.
} 
and command but not love for God Himself in His essence or attributes. ${ }^{11}$ Bell corrects this and shows how Ibn Taymiyya sets the Ash'arī arguments aside to make room for his own doctrine that God loves human beings and that human beings can and should worship and love God for Himself in His essence, not merely for the blessing and reward that they might gain from obeying Him. ${ }^{12}$

Additionally, Bell examines how Ibn Taymiyya relates God's love to God's will, and this draws him into an analysis of the shaykh's theodicy. Ibn Taymiyya rejects the Ash'arī theologian al-Juwaynī's reduction of God's love (mababba) and good pleasure to nothing more than God's will in creating all things, even unbelief and iniquity. The shaykh agrees with the Ash'arīs that God wills all that exists with His creative will (iräda khalqiyya), but, whereas al-Juwayni affirms that God loves even the unbelief and iniquity that He creates, Ibn Taymiyya asserts that God hates these evils. What God loves is the belief and obedience that correspond to His prescriptive or legislative will (iräda shar iyya). God does create things that He hates, but He does this only for the sake of a wise purpose (bikma) that He loves. ${ }^{13}$ With this, Bell observes, Ibn Taymiyya subordinates God's will to God's love, and, in the shaykh's understanding, God may forgo creating something that He loves in order to attain something else which is better. Thus, while God loves what He wills humans to do in obedience to His law, he also loves the wise purpose in everything that He wills to create. ${ }^{14}$

Probably due to his focus on love theory, Bell does not notice that Ibn Taymiyya is often content to leave the explanation for evil at the level of God's wise purpose without going on to God's love. He also does not mention that Ibn Taymiyya uses other theological idioms to speak of the substance of God's creative and legislative wills. Both points will become apparent in Chapter Three below. However, metaphysical difficulties in Ibn Taymiyya's notion of wise purpose do prompt Bell to discuss God's self-sufficiency.

11 Laoust, Essai, 471.

12 Bell, Love Theory, 46-49, 74-91. On worshipping God for His essence, see above Chapter One, as well as below Chapter Three, where parallels are noted between God's divinity, His command and His very self, in which case perhaps Bell and Laoust are both correct: loving God's command is loving God in His essence.

13 Bell, Love Theory, 69, explains that hikma is translated better as "wise purpose" than as "wisdom" because it envisions some end or reason that is sought or loved. In addition to evidence presented by Bell, the translation of hikma as "wise purpose" is supported by the fact that Ibn Taymiyya occasionally uses it synonymously with the term 'illa ghä iyya (final cause) denoting purpose and aim (see Iräda, MF 8:88 and Hasana, MF 14:299).

14 Bell, Love Theory, 56-73. 
Bell correctly observes that Ibn Taymiyya employs the term hikma to give moral significance to the created world in the face of the Ash'ari denial that God performs acts on account of causes, reasons or purposes. However, he also argues that Ibn Taymiyya uses hikma instead of gharad, a common Mu'tazili term for purpose, in order to bypass the Ash'arī objection that gharad implies need in God. According to Bell, the shaykh believes that God wills and creates for a "cause, reason or end" but yet that "God is definitely not moved by a 'purpose." "' Bell's distinction is not sufficiently precise. While it is true that Ibn Taymiyya prefers hikma to gharad, Bell does not point out that the shaykh still takes it upon himself to defend bikma against the same objections that the Ash'arīs level against the $\mathrm{Mu}^{\prime}$ tazilī understanding of gharad. It entails need in God, temporal origination (budüth) in God, and an infinite regress. Examination of Ibn Taymiyya's response to these three Ash'arī charges will take up the bulk of the present chapter, and this will show that God's acts in his view are purposive in a stronger sense than that held even by the Mu'tazilis.

Bell falters because he misapprehends Ibn Taymiyya's reason for rejecting gharad. In Minhäj, from which Bell derives his argument, the shaykh understands hikma and gharad to have identical senses, but he prefers to carry out his discussion in terms of the former. Before responding to Ibn al-Muțahhar al-Hillī's claim that the Sunnis believe that "God has no gharad in his acts," Ibn Taymiyya shifts the discussion to the equivalent hikma: "the gharad which is the bikma," and, "for a gharad, that is, a bikma."16 Then, he notes that the rejection of purpose, whether under the name gharad or bikma, is limited only to a few Sunnīs such as al-Ash'arī and his followers. Rather, "Most Sunnīs establish wise purpose ( is $\mathrm{He}$ - and that $\mathrm{He}$ acts to the profit and benefit of His servants. ${ }^{\prime 17} \mathrm{Ibn}$ Taymiyya explains elsewhere in Minhäj why he prefers hikma to gharad. Those who affirm hikma but reject gharad do not use gharad with respect to God because it may connote injustice and need in common usage. The shaykh continues, "When people say, 'So-and-so did that for a gharad', and, 'So-and-so has a gharad toward someone', they often mean by this some blameworthy intention such as injustice, abomination, etc." ${ }^{18}$ Thus, the

\footnotetext{
15 Bell, Love Theory, 69.

16 Al-Hillîs comment is as quoted in Minhāj, 3:7/1:264-5. The two cases in which Ibn Taymiyya shifts from gharad to hikma are found in Minhāj, 3:14/1:266.

${ }_{17}$ Minhāj, 3:14/1:266. Al-Hillī himself, as quoted in Minhāj, 1:125/1:30 and 1:454/1:126, uses hikma as a synonym for gharad, as does Ibn Taymiyya in Nubuwwät, 143.

${ }_{18}$ Minhāj, 2:314/1:215. Cf. Minhāj, 1:455/1:126.
} 
shaykh eschews gharad not to avoid purpose in God's acts but only to avoid the negative connotations gharad may carry in ordinary speech. This sort of linguistic analysis is identical to what Bell observes in Ibn Taymiyya's rejection of the term 'ishq (passionate love). The shaykh believes that 'ish $q$ could be applied to divine love but should not be because it may carry connotations of excessive passion and earthly pleasure. Moreover, 'ish q need not be used because it is not found in revelation. ${ }^{19}$

Although momentarily sidetracked claiming that Ibn Taymiyya's God is not moved by a purpose, Bell does observe that the shaykh still has a problem with God's sufficiency when engaging the Mu'taziliss. For the latter, God acts for a reason or a purpose that benefits humankind, not God Himself. Ibn Taymiyya retorts in Iräda that this is irrational. Some measure of pleasure, reward or praise returns to the agent for the wise purpose in his act. ${ }^{20}$ But does this not imply a God who acts out of need? Bell argues that the shaykh solves this problem-or rather evades it—with God's love of His wise purpose. He states, "Having asserted that the relationship between God and his hikma was one of love, Ibn Taymìya felt himself unobliged to deal with the problem of a need or a lack on the part of God which the concept of hikma might otherwise have entailed."21 Drawing on Minhäj and Iräda, Bell explains that Ibn Taymiyya takes refuge in the Neoplatonic notion of God's self-love employed by medieval Sufis - we may add Ibn Sinnā-and that the shaykh often expresses this in his own idiom as God's self-praise. God's self-love and self-praise far outstrip His love for creatures and their love and praise of Him, and this renders Him completely sufficient apart from them. ${ }^{22}$

This is not quite the whole story. Contrary to what Bell might have lead us to believe earlier, Ibn Taymiyya does respond to the Ash'arī objection that bikma implies need in God, and, as we will see below, he does so by shifting the meaning of God's sufficiency (ghin $\bar{a})$ from God's essential indifference to the world-the Kalām view - to God's lack of need for help in creation. Bell does in fact note this in an overly concise final paragraph on the topic of God's sufficiency. Drawing again on Iräda, he explains that Ibn Taymiyya's God is free of want and deficiency because "everything worthy of love in his creatures is God's own work." Bell then concludes that creation does not

19 Bell, Love Theory, 81. Cf. Mahabba, 52-8.

${ }^{20}$ Iräda, MF 8:89-90, as discussed in Bell, Love Theory, 69-70.

${ }^{21}$ Bell, Love Theory, 71.

22 Bell, Love Theory, 71-2, based on Minhäj, 5:408/3:101-2 and Iräda, MRK 1:374, which is equivalent to MF 8:144. 
arise from need in God but from the "natural and logical" outworking of God's attributes-especially love-through God's acts. ${ }^{23}$ Since "natural" and "logical" imply necessity, is then creation necessary and even eternal for Ibn Taymiyya? This question Bell does not answer.

Although halting at times, Bell breaks important new ground and is accurate in his basic intuitions. His difficulties derive from failing to bring out two key concepts in Ibn Taymiyya's theology. First, as Bell begins to perceive in the remark just noted, the shaykh agrees with the Neoplatonism of Ibn Sinna that God is essentially productive. Second, Ibn Taymiyya easily dispenses with creation as eternal emanation because he reconfigures the nature of God's essence. For both Ibn Sīnā and the Kalām theologians, timeless and unchanging eternity is what ultimately characterizes the perfection of God. Ibn Taymiyya breaks with this mainstay of the Greek and Islamic intellectual traditions and envisions God's essential perfection as perpetual dynamism. Purposive activity is of the very essence of God-God is indeed moved by purposes, but purposes that are His own-and God has been creating for wise purposes from eternity. At the level of creation itself, nothing created is eternal, but there have always been created things of one sort or another. What follows below is closer analysis of relevant material in Iräda, Minhāj and a few other texts showing how Ibn Taymiyya works out this theological vision in response to Kalām, and especially Ash 'arī, objections to wise purpose in God's acts.

\section{Ibn Taymiyya's Classification of Views on Wise Purpose/Causality in the Will of God}

In the fatwa Iräda, Ibn Taymiyya elaborates on God's willing for a wise purpose in response to an inquiry concerning causality $\left(t a^{\prime} l i l\right)$ in the will of God. The fatwa inquiry outlines the metaphysical options concisely and provides a useful entry into Ibn Taymiyya's typical classification of views on this question:

Concerning the goodness (busn) of the will (iräda) of God-Exalted is $\mathrm{He}-$ in creating creatures and bringing forth the human race. Does $\mathrm{He}$ create for a cause ('illa) or for other than a cause? If it is said, "not for a cause," He is aimless-Exalted is God above that. If it is said, "For a cause," and if you say

${ }^{23}$ Bell, Love Theory, 73, based on Iräda, MRK 1:375-6, which is equivalent to MF $8: 146-7$. 
that it is pre-eternal, it follows necessarily that the effect is pre-eternal (lam yazal). ${ }^{24}$ And if you say that it is originated (mubdatha), it follows necessarily that it has a cause, but an endless chain is absurd. ${ }^{25}$

Ibn Taymiyya identifies the advocates of each metaphysical position mentioned in the inquiry as follows. ${ }^{26}$ Those who deny that God wills for a cause are the Ash'arīs and the Zāhirīs, among them Ibn Hazm (d. 456/1064). Ibn Taymiyya identifies those who maintain that God acts for an eternal cause entailing an eternal effect as the philosophers upholding the eternity of the world. The shaykh then divides those who teach that God acts for an originat-

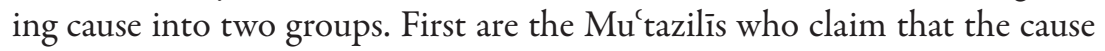
or wise purpose is a created thing disjoined (munfasil) from God, which consists only in His beneficence to creatures and giving them opportunity to earn reward. In this view, however, God Himself is indifferent to His wise purpose: "No judgment (bukm) returns to Him from that." ${ }^{27}$ Second are those who disagree with the Mu'tazilīs on this point: jurists, hadith scholars, Sufīs, Karrāmīs and some philosophers. This latter group maintains that a judgment from God's act returns to Him and that He does what He does "for a wise purpose that He knows." 28

A similar classification in the first volume of Minhāj leaves out the philosophers, but identifies more adherents of the other views. Ibn Taymiyya notes that the Islamic tradition is agreed that God is endowed with wisdom (bikma), but he points out that there is no agreement on what God's wisdom implies. Jahm b. Șafwān and the Ash'arīs deny causality in the will of God, but most Sunnīs uphold it, believing that God has a wise purpose in His creation and His command. The shaykh adds that not only the Mu'tazilīs and Shīis following Mu'tazilī theology adhere to this but also Sufis, hadith scholars and the Karrāmīs, as well as followers of each of the four Sunnī schools of law. Among the Shāfi īs, he names Abū 'Alī b. Abū Hurayra (d. 345/ 956) and Abū Bakr al-Qaffāl (d. 365/975-6). Among the Hanbalīs, he lists Abū al-Hasan al-Tamīmī (d. 371/982) and Ibn 'Aqīl, and he mentions that Abū Ya là sometimes upholds one position and sometimes the other. As in

\footnotetext{
${ }^{24}$ I usually translate Arabic terms implying some dimension of eternity as follows: abad (post-eternity), abadì (post-eternal), azal (pre-eternity), azalì (pre-eternal), qidam (eternity), qadim (eternal), lam yazal (had been/has been/was... pre-eternal/from eternity). The literal meaning of lam yazal is 'has not ceased...' but this translation is avoided because it often yields cumbersome double negatives in English.

${ }^{25}$ Iräda, MF 8:81.

${ }^{26}$ Iräda, MF 8:83-93.

${ }^{27}$ Iräda, MF 8:89.

28 Iräda, MF 8:93.
} 
Iräda, Ibn Taymiyya sets the Mu'tazilīs and their Shîi 1 followers apart from the rest of the Sunnis because they hold the view-irrational in the shaykh's eyes - that the cause is disjoined from God and God is indifferent to whether it exists. ${ }^{29}$ For Ibn Taymiyya, the cause is not disjoined from God, and God is not indifferent to His wise purposes. The shaykh elaborates the theology that sustains these convictions in the course of refuting arguments for the Ash'arī position, and to these arguments we now turn.

\section{The Ash' ari Case against Causality in the Will of God: It Entails Imperfection and Origination in God, as well as an Infinite Regress}

In Iräda Ibn Taymiyya sets out the Ash'arī case against causality and wise purpose in God's will as follows. First, causality in God's will makes God imperfect: "If [God] created creation for a cause, He would be imperfect without it and perfected (mustakmal) by it." ${ }^{30}$ In Minhāj Ibn Taymiyya relates the same argument thus: "Whoever acts for a cause is perfected by it, because if the occurrence of the cause were not better than its nonexistence, it would not be a cause. One who is perfected by another is imperfect in himself. This is impossible for God." 31 This form of the argument makes explicit the premise that the cause allegedly perfecting God arises from outside God Himself. As we will see below, this argument does not undermine Ibn Taymiyya's theology because he locates the cause within God's essence and reinterprets the meaning of God's perfection and sufficiency.

The second objection reported by Ibn Taymiyya in Iräda follows the sequence of dilemmas outlined in the inquiry prompting the fatwa. For the sake of argument, the Ash'arīs admit the Avicennan proof for the eternity of the world: "If [the cause] is eternal, the eternity of the effect is necessary." ${ }^{2}$ Then, they pose a dilemma, the first horn of which reads, "If it were said that [God] acts for an eternal cause, it follows necessarily that no originating events originate, but that is contrary to what is observed." Here our experience of temporal origination in this world is taken to preclude the eternity of its cause. This is the primary argument Ibn Taymiyya himself employs

${ }^{29}$ Minhāj, 1:141-6/1:34-5.

${ }^{30}$ Iräda, MF 8:83.

31 Minhäj, 1:145/1:35.

32 Iräda, MF 8:83. 
against the philosophers, but it raises the question of how the eternal God brings forth originating events in time..$^{33}$

The second horn of the dilemma states, "If it is said that [God] acts for an originating cause, two prohibited things follow necessarily." The first "prohibited thing" mentioned in Iräda is that God becomes "a substrate (mahall) for originating events (hawädith)." ${ }^{34}$ In Minhäj Ibn Taymiyya reports how the Mu'tazili's evade this with their doctrine that God acts for a cause that is disjoined from His essence. However, the Ash'arīs counter that this cause must have some impact on God. Otherwise, it would not be a cause. If then it is disjoined from God-as the Mu'tazilīs say-His acting for its sake implies that the cause-which is something outside of Himself-perfects Him. Conversely, if the cause is "subsisting in Him ( $q \vec{a}$ im bihi)," the Ash'arīs argue, "it necessarily follows that $\mathrm{He}$ is a substrate for originating events," 35 in which case God becomes subject to temporal origination. As Ibn Taymiyya notes, the Mu'taziliss do not believe that the cause has any impact on God. God is indifferent in Himself to whether the cause brings something into existence or not. ${ }^{36}$

Ibn Taymiyya sets out the two horns of this dilemma posed by the Ash'arīs somewhat differently in Iräda: "[1] If the cause is disjoined from Him, and if no judgment $(\mathrm{bukm})$ returns to Him from it, its existence will not be worthier of Him than its nonexistence. [2] If it is supposed that a judgment returns to Him from it, that [judgment] is originating, and thus originating events subsist in Him." ${ }^{37}$ Below it will become clear that Ibn Taymiyya adopts the second horn of the dilemma as his own view, although he prefers to speak not of originating events subsisting in God's essence but rather, equivalently, of God's voluntary acts.

In Iräda the second "prohibited thing" ensuing from originating causality in God's acts is an endless chain or infinite regress (tasalsul). As the Ash'arīs see it, a cause precipitating God's act must itself be originated and so requires an originated cause of its own, and so on ad infinitum in an endless chain

${ }^{33}$ Irāda, MF 8:84. Fakhr al-Dīn al-Rāzī recounts this argument in Arba'in, 78; and in Al-Mațālib al-äliyya min al-îlm al-ilähī, ed. Ahmad Hijāzī al-Saqā, 9 parts in 5 vols (Beirut: Dār al-kitāb al-'arabī, 1407/1987), 4:55-6. The latter text is discussed in Muammer İskenderoğlu, Fakhr al-Din al-Rāzi and Thomas Aquinas on the Question of the Eternity of the World (Leiden: Brill, 2002), 80-1.

${ }^{34}$ Iräda, MF 8:84.

${ }_{35}$ Minhäj, 1:145/1:35.

${ }^{36}$ Minhāj, 1:145/1:35.

${ }^{37}$ Irāda, MF 8:84. 
of originating events. ${ }^{38}$ The impossibility of an infinite regress is also a key argument in the Kalām arsenal against the eternity of the world doctrine held by philosophers like Ibn Sīnā. For this reason, Ibn Taymiyya gives considerable attention to the doctrine of creation when discussing causality in the will of God. ${ }^{39}$

Exposition of Ibn Taymiyya's responses to these Ash'arī arguments will be in reverse order of the latter's presentation here. Thus, we begin with his rejoinder to the Ash'arī contention that causality in God's will leads to an endless chain and then move to his replies to the charges that this involves originating events in the essence of God and God's imperfection.

\section{Ibn Taymiyya's Case for a God Who Acts Perpetually for Wise Purposes and Creates from Eternity}

In the edited version of Minhäj, Ibn Taymiyya's response to the Ash'arī objection that wise purpose in God's will entails an endless chain or infinite regress takes up over 270 pages of the first volume..$^{40}$ As this treatment far exceeds any other in length and detail, it constitutes my primary source. By the same token, however, this is not the place for an exhaustive account of this long passage, and I will thus highlight only its main arguments. Ibn Taymiyya first explains very briefly that the sequence of God's wise purposes constitutes an endless chain of originating events into the future, not into the past:

When [God] performs an act for a wise purpose, the wise purpose obtains after the act. When from this wise purpose another wise purpose is sought after it, this is an endless chain into the future. This wise purpose which has occurred is beloved to Him, and it is a cause of a second wise purpose. He-Glory be to Him-does not cease originating, with respect to wise purposes, what $\mathrm{He}$ loves and making it a cause of what He loves. ${ }^{41}$

Here Ibn Taymiyya gives wise purpose the sense of the fully realized objective or final cause for which acts are carried out, and he momentarily bypasses

${ }^{38}$ Iräda, MF 8:84. Cf. Minhāj, 1:145/1:35.

39 In what follows, I leave aside Ibn Taymiyya's many writings on God and creation that do not fall within treatments of causality in God's will. See for example Dar', passim; Nubuwwāt, 71-92; Safadiyya, passim; and 'Imrān, MF 18:210-243, which is translated in Hoover, "Perpetual Creativity," 300-329. For overviews of medieval Islamic arguments for and against creation ex nibilo and the eternity of the world, see the works of Davidson, Proofs for Eternity, and İskenderoğlu, Fakbr al-Din al-Räzì.

${ }^{40}$ Minhäj, 1:146-420/1:35-117.

${ }^{41}$ Minhāj, 1:146/1:35-6. Cf. MF 8:380. 
the fact that the wise purpose had a prior existence as an intention in the mind of God. The shaykh reasons that there should be no objection to an endless chain in the future because the great majority of Muslims and even non-Muslims believe that Paradise and the Fire will be perpetual. ${ }^{42} \mathrm{After}$ this, Ibn Taymiyya's turns in Minhāj to the question of an endless chain into the past. He first sets out the position that he will defend:

[God] has been active from eternity when He willed with acts that subsist in His self by His power and His will one after another.... He has been speaking from eternity by His will, and $\mathrm{He}$ has been acting from eternity by His will one thing after another... Everything other than God is originated, created [and came into] being after it was not. In the world, there is nothing eternal accompanying God. ${ }^{43}$

The question of God's acts subsisting within Him will be taken up later. First, however, we are concerned with Ibn Taymiyya's claim that God's creative activity extends back in time to pre-eternity while no one created thing has existed from eternity. To make intellectual space for this vision of God and creation, Ibn Taymiyya must refute both Kalām arguments for creation ex nibilo and philosophical arguments for the world's eternity.

\section{The Philosophers' Argument that God Is an Eternal Cause Implies that Nothing Originates}

The first of the philosophers' arguments that Ibn Taymiyya addresses in Minhäj was noted when discussing Ash'arī arguments above. As the philosophers see it, the Creator is a complete cause ('illa tämma) necessitating in His essence and necessarily entailing His effect (ma'lül), that is, the world, without a delay in time. Thus, the world is the eternal effect of God. ${ }^{44}$ For Ibn Taymiyya, however, an eternal complete cause entirely precludes any kind of origination in time, which manifestly contradicts human experience of temporal origination:

Temporally originating events are observed in the world. If the Artisan were necessitating by His essence [and] a complete cause necessarily entailing its

\footnotetext{
${ }^{42}$ Minhäj, 1:146/1:36.

${ }^{43}$ Minhāj, 1:147-8/1:36. For Ibn Taymiyya’s understanding of God's speech, see Hoover, "Perpetual Creativity", 296-9.

${ }_{44}$ Minhāj, 1:148/1:36; and Iräda, MF 8:85. This argument goes back to the fifth century Neoplatonist Proclus who maintains that creation would involve change or prior imperfection in the cause of the world. See Davidson, Proofs for Eternity, 56-67, for proofs of this kind from Proclus to Aquinas.
} 
effect, not one originating event would originate in existence since it is impossible for what originates to emanate from a pre-eternal, complete cause. If the world had been eternal, its Creator would have been a complete cause. Nothing of the effect of a complete cause comes after it. So, it follows necessarily from that that nothing originates in the world. Therefore, the origination of events is a proof that their Agent is not a complete cause in pre-eternity, and, when the complete cause in pre-eternity is disproved, holding to the eternity of part of the world is vain. ${ }^{45}$

Under the conviction that nothing temporal can originate from the eternal, Ibn Taymiyya expends much effort to show that the philosophers' attempts to arrive at temporal origination by way of intermediaries fails. He reports that the philosophers themselves do not say that events arise out of a preeternal complete cause. All agree that a complete cause necessarily entails its effect without any delay between the cause and the effect and that the cause of an originating event only becomes complete or decisive at the very instant that the event comes into existence. Rather, the philosophers-here he mentions Ibn Sinā explicitly-explain that God is the pre-eternal complete cause of the eternal elements of the world such as the celestial spheres (aflak). The eternal motion of the spheres is then the source of the change that occurs in the world by functioning as the cause of receptacles (qawäbil) and preparednesses $\left(i_{s t}{ }^{\prime} d \bar{a} d \bar{a} t\right)$ that regulate the perpetual emanation of the First Cause. ${ }^{46}$

Ibn Taymiyya does not accept such explanations of how change and motion arise in the world. He maintains that it is incongruous for any events whatsoever to originate from an eternal complete cause, whether directly or indirectly. When originating events such as the receptacles are traced to God, it implies that God is not the eternal complete cause of them. Conversely, if God is the eternal complete cause for any so-called originating events, these events must be either eternal or nonexistent. God as an eternal complete cause ultimately "implies the nonexistence of originating events or the eternity of originating events, and both of them oppose what is observed." ${ }^{47}$ The shaykh concludes that the philosophers posit motion arising out of nothing. Since the motion of the celestial spheres, which is the cause of all other motion, cannot arise from a pre-eternal complete cause, the spheres must be moving of their own accord. Ibn Taymiyya rejects this as inadequate, and he asserts

${ }^{45}$ Minhäj, 1:148/1:36.

${ }_{46}$ Minhāj, 1:336-8/1:92-3; and Minhāj, 1:182-7/1:45-7.

${ }^{47}$ Minhäj, 1:344/1:95. 
that there must be something above the celestial spheres necessitating their motion. $^{48}$

\section{The Philosophers Argue Correctly that the Kalam Theologians Posit Temporal Origination without a Cause}

A second proof for the eternity of the world that Ibn Taymiyya attributes to the philosophers, and to Ibn Sinna in particular, reduces the Kalām view that God created the world ex nibilo to absurdity. ${ }^{49}$ In Minhäj the shaykh presents the proof as follows:

The philosophers' support for the eternity of the world is their view that the [temporal] origination of originating events without an originating cause is impossible. Positing an essence stripped (mu'attal) of acting that was not acting [but] then acted without an originating cause is impossible. ${ }^{50}$

Ibn Taymiyya denies that this argument proves the eternity of the world: "This view does not prove the eternity of any individual thing belonging to the world, the celestial spheres and otherwise. It proves only that [God] has been acting from eternity." ${ }^{\prime 1}$ Elsewhere in Minhāj , he explains further: "All of what you [philosophers] and those like you mention proves only the perpetuity (dawam) of action, not the perpetuity of an individual act and not of an individual enacted thing." 52 What this argument proves for Ibn Taymiyya is only that God has been acting from eternity. Against the philosophers, he denies that it implies the eternity of any particular part of the world. The shaykh also points out that the philosophers' argument for the eternity of the world from an eternal complete cause falls afoul of the very principle of origination that they use in the present proof against the Kalām theologians. As noted in the previous subsection, the shaykh argues that the philosophers cannot adequately explain the origin of movement in the celestial spheres unless they permit the origination of events without a temporally originating cause. ${ }^{53}$

\footnotetext{
${ }^{48}$ Minhāj, 1:343-6/1:94-5. Cf. Minhāj, 1:150-5/1:37-8, 1:218/1:56, 1:323-334/1:8891; Iräda, MF 8:86-7; and Nubuwwāt, 132-133.

49 Minhāj, 1:154/1:38. For this argument in Ibn Sīnā, see al-Najāh (Cairo: Maṭba'at alsa āda, 1331/1913), 412-422; and Al-Mabda' wa al-ma'äd, 46. For its history, see Davidson, Proofs for Eternity, 51-6.

50 Minhāj, 1:148/1:36.

${ }^{51}$ Minhāj, 1:148-9/1:36.

52 Minhäj, 1:351/1:97.

53 Minhāj, 1:177/1:44.
} 
Beyond this, Ibn Taymiyya does agree with the philosophers that their proof refutes the Kalām doctrine of creation ex nibilo. The shaykh attributes the denial of God's perpetual activity to the Mu'taziliss, the Ash'aris, the Karrāmīs and the Shîîs, and he traces the foundation of this Kalām position to Jahm b. Șafwān and Abū al-Hudhayl al-'Allāf who presuppose that originating events without a beginning are impossible and that the genus of events must have had a beginning. Ibn Taymiyya argues that positing a necessary beginning to the genus of temporally originating events renders the origination of any events prior to the emergence of the whole genus impossible. Since the genus of events has a beginning, no origination of events could have occurred prior to this beginning. This raises the question of how the genus of originating events itself became possible after having been impossible. Ibn Taymiyya follows the philosophers in asserting that such a transition was impossible unless a cause emerged to produce it. However, this poses the problem of how a cause could originate before origination was possible. For the shaykh, all of this ends in absurdities, and he concludes that origination must have been possible from eternity since there could not have been an origination of the possibility of origination. ${ }^{54}$

\section{God Wills with an Infinite Regress of Willings}

Ibn Taymiyya also casts this argument of the philosophers in terms of the principle of preponderance. That is, every possibility requires a complete preponderator (murajjih tamm) that tips the scales in favor of its existence over its nonexistence, and, in refutation of the Kalām doctrine of creation ex nibilo, God cannot change from the impossibility of acting to the possibility of acting without a preponderator. ${ }^{55}$ According to the philosophers and Ibn Taymiyya, the difficulty with the Kalām outlook is that the world originates in time without a cause preponderating its origination. Al-Ghazālì responds to this problem in his Tahäfut al-faläsifa by giving the function of preponderance to the eternal divine will. He argues that it is in the very nature of God's eternal will to have designated the time at which the world originated. The world did not come into existence until the point at which God in His eternal will had set, and He had not willed it to be created prior to that. ${ }^{56}$ Ibn Taymiyya rejects this, and, in the first volume of Minhäj, he

${ }^{54}$ Minhäj, 1:155-161/1:38-40.

55 Minhäj, 1:161-2/1:40, 1:195-6/1:49.

${ }^{56}$ Al-Ghazālī, The Incoherence of the Philosophers, 15-26. 
asserts that al-Ghazāli erred in adopting this Kalām position, that is, the idea that "one who is powerful and choosing preponderates one of his two possibilities over the other without a preponderator." ${ }^{\text {7 }}$

Ibn Taymiyya denies that an eternal will can give rise to temporal origination, and he asserts that it is impossible for God to will a concrete individual in eternity. ${ }^{58}$ The shaykh argues that if God had an eternal will that applied in general to all things, then everything would be eternal and nothing could originate. This denies the origination and motion that we actually see, such as the motions of the sun, moon, celestial bodies, wind, clouds, living beings and plants. Rather, God's willing of something to happen occurs at the time that it happens. ${ }^{59}$

The dynamic quality of God's will in Ibn Taymiyya's thought becomes clearer in his criticism of the philosopher Abū al-Barakāt al-Baghdādī (d. ca. 560/1165). The shaykh reports that Abū al-Barakāt in his Mútabar posits two divine wills: an eternal will to will what is eternal-the celestial sphere-and successive wills or newly arising willings (irädāt mutajaddida) subsisting in the essence of God to will successive originating events. ${ }^{60}$ The shaykh first notes that an object of will is necessarily originated in time: "Something being willed necessarily entails its origination." ${ }^{61}$ What is eternal cannot be an object of God's will. Thus, Ibn Taymiyya believes that it is totally unnecessary to posit an eternal divine will because everything other than God, including the celestial sphere, is originated. ${ }^{62}$ Originating events may be accounted for adequately with successive willings: "If it is permissible that He has successive willings perpetual in species, it is not impossible that everything other than Him originate by these willings." ${ }^{63}$

The shaykh elaborates a bit more elsewhere in the first volume of Minhāj on the operation of God's will and power using the conceptual framework of complete causality. His fundamental premise is that someone who wills decisively to do something that he is able to do will necessarily produce the act. Applied to God, "Whatever God wills is, and whatever He does not will is not. Truly, He is powerful over what He wills. With complete power

57 Minhāj, 1:356/1:99. Cf. Irāda, MF 8:147-9.

58 Minhāj, 1:165/1:41, 1:75/1:43.

59 Minhäj, 1:234-5/1:61 and 1:296-8/1:80-1.

${ }^{60}$ Minhāj], 1:178/1:44, 1:219-220/1:57, 1:338/1:93; Abū al-Barakāt Hibat Allāh b. 'Alī b. Malkā al-Baghdādī, Kitāb al-mùtabar fì al-hikma, 3 vols. (Hyderabad: Jam iyyat dāirat al-ma'ārif al-'uthmāniyya, 1357-8/1938-9), 3:164, cf. 3:45.

${ }^{61}$ Minhāj, 1:179/1:44.

${ }^{62}$ Minhāj, 1:178-9/1:44-5, 1:219-220/1:57.

${ }^{63}$ Minhāj, 1:179/1:44-5. 
(al-qudra al-tämma) and decisive will (al-mashï a al-jäzima), the existence of the act is necessary." ${ }^{64}$ God is the one Necessitating in His Essence (al-müjib $b i-l-d h \bar{a} t)$, not in the philosophers' sense of being an eternal complete cause, but as "necessitating what $\mathrm{He}$ originates by His will and His power." ${ }^{55}$

Ibn Taymiyya's notion of God's decisive and necessitating willing as a complete cause faces philosophical difficulties. By virtue of Ibn Taymiyya's adherence to the principle of preponderance, each originating act of "decisive will" must be activated by a prior originating cause that makes its existence preponderate. The shaykh may say that "Whatever God wills is, and whatever He does not will is not," but there still must be a complete cause precipitating each act of willing. If we posit an infinite regress of decisive divine wills and complete causes whose effects are immediately necessary, we may inquire into the ground of this whole infinite regress. Is the series as a whole self-preponderating just as Ibn Taymiyya believes the eternal motions of the spheres to be for the philosophers? Or does it go back to a First Cause that preponderates the existence of the series? If it does go back to a First Cause which is eternal and complete, it would seem that the chain of complete causes and decisive wills must lock up into a timeless series under the eternal complete First Cause, which would yield the eternity of the world. As we will see, the shaykh resists this conclusion by insisting that willed or created things come into existence in time after they did not exist.

Ibn Taymiyya may not be able to evade the difficulty of explaining how temporal origination arises without violating the principles of preponderance and originating causality that he employs polemically against his adversaries. What is significant, however, is that he locates the boundary between the eternal and the temporal at a different point from either the Kalām theologians or the Neoplatonic Islamic philosophers. Whereas the latter explain temporal events as the product of the eternal motion of the celestial spheres and al-Ghazāli explains them with God's eternal and unchanging will whose nature it is to preponderate in time, Ibn Taymiyya posits their source in an infinite regress of divine willings within God. Although Ibn Taymiyya does not say so explicitly, he places the boundary between time and eternity in God's very essence.

${ }^{64}$ Minhāj, 1:405/1:113.

${ }^{65}$ Minhāj, 1:164/1:41. Cf. Minhäj, 1:404/1:113. 


\section{God in His Perfection Acts, Wills and Creates from Eternity}

To this point, the arguments surveyed have been largely deconstructive. Ibn Taymiyya maintains that the eternal divine will of the Kalām theologians and the eternal complete cause of the philosophers cannot explain the emergence of originating events. Every such argument founders on the shoal of the principle of preponderance or originating causality. The alternative set forth by Ibn Taymiyya is that God has been willing and acting from eternity, with eternity here meaning not timelessness but time without beginning. The shaykh also proves his position positively from the necessity of God's perfection.

Invoking considerations of God's perfection discussed above in Chapter One, Ibn Taymiyya first explains in Minhäj that the Creator has a greater right to perfections found in creatures than do the creatures themselves because creatures derive their perfections from the Creator. Likewise, God has an even greater right to be exonerated of imperfections from which creatures exonerate themselves. ${ }^{66} \mathrm{~W}$ ith these principles in place, the shaykh argues that activity is not neutral with respect to perfection because creating, which he takes here to be synonymous with acting, is better than not creating. Moreover, in an obvious stab at the philosophers, Ibn Taymiyya argues that one who performs successive acts is better than one who has something conjoined to him from eternity:

[People from the Muslim, Jewish and Christian religious communities $]^{67}$ say also that acting is an attribute of perfection. They reply to the Kalām theologians who say that it is neither an attribute of perfection nor imperfection: $\mathrm{He}$-Exalted is $\mathrm{He}$ - has said, "Is then He Who creates as one who does not create? Will you not then remember?" (Q. 16:17). That being the case, it is reasonable that the agent who acts by his power and his will is more perfect than one having no power and no will. The powerful, freely choosing (mukbtär) agent who performs acts one after the other is more perfect than one the product of whose act is necessarily concomitant with him [and who] is not powerful to originate anything or to change anything from one state to another. ${ }^{68}$

Ibn Taymiyya also casts the latter part of the quoted argument into a contrast between the whole species of acting and an individual eternal act. First, he

\footnotetext{
${ }^{66}$ Minhāj, 1:371/1:103. Cf. Minhāj, 1:417-8/1:116.

${ }^{67}$ The antecedent of the third person plural pronoun bum beginning this sentence is found a few pages earlier in Minhäj, 1:367/1:102, at the beginning of a series of proofs against those who believe in the eternity of the world.

${ }^{68}$ Minhāj, 1:371-2/1:103. Cf. Minhäj, 1:384/1:107.
} 
says that the eternity of the species of enacted things in the world is more perfect than the eternity of one individual. Then, he argues that agency over a species of things occurring successively is more perfect than agency over an individual thing. He adds that the perpetuity of agency over an individual thing is an unknown concept and that the perpetuity of agency does not entail the perpetuity of an individual. What it does entail is the origination of the individuals of the species. ${ }^{69}$ In sum, Ibn Taymiyya maintains that God's perfection requires that $\mathrm{He}$ has been acting and creating the species of originating things from eternity. God's ultimate perfection is found not in the Kalām theologians' and philosophers' ideals of eternal stillness and changelessness, but in God's eternal activity and creativity.

\section{No One Originating Event Is Eternal, but the Genus of Originating Events Is Eternal}

This brings us to closer consideration of Ibn Taymiyya's view of the created world itself. In Minhāj the shaykh claims that God's perpetual activity does not mean that any one thing in the world is eternal. God is "perpetual of

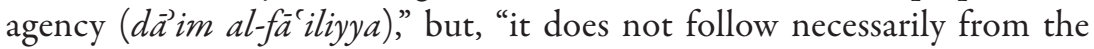
perpetuity of His being an agent that there is an individual, eternal enacted thing with Him." ${ }^{70}$ Rather, originating events come into being after they were not, and all things other than God are originated and created: "Everything except God is created [and came into] being after it was not.".71

With the phrase, "being after it was not (kä in ba'd an lam yakun)," the shaykh denies the eternity of any individual thing apart from God and also distinguishes himself from Ibn Sina and others who speak of the world as eternal but originated and possible. The issue turns on Ibn Sinās understanding of possibility and causal priority. The philosopher maintains that the world can be eternal but yet possible (mumkin) in the senses that it is not self-sufficient and that it might not have been. Considered in itself, the world is possible. It only becomes necessary through another, namely, God who is the eternal efficient cause of the existence of the world. Ibn Taymiyya's summary of this idea reads, "The world is an effect (ma'lül) of [God's]. He is necessitating it and emanating it. He is prior to it in honor, causality and nature. He is not prior to it in time." ${ }^{.72}$ Moreover, according to the shaykh,

${ }^{69}$ Minhāj, 1:387/1:108.

${ }^{70}$ Minhäj, 1:336/1:92.

${ }^{1}$ Minhäj, 1:359/1:100. Cf. Minhāj, 1:298/1:81.

2 Minhäj, 1:149/1:36. 
Ibn Sīnā calls the world originated (muhdath) only in the sense of its being the effect of an eternal cause. ${ }^{73}$

Against Ibn Sīnā, Ibn Taymiyya marshals the support of Aristotle and Ibn Rushd to show that what is possible originates in time and that something originated and possible must be preceded by nonexistence in time. ${ }^{74}$ The shaykh writes, "Aristotle and the ancients among his followers along with the rest of the people of reason say that the possible whose existence or nonexistence is possible is only originated, being after it was not." ${ }^{35}$ For Ibn Taymiyya, it is not possible that something eternal could have been nonexistent. Likewise, it is not possible that something possible be eternal. ${ }^{76}$

Ibn Taymiyya asserts in Minhäj that everything except God is originated and preceded by nonexistence and that there is nothing eternal in the world. ${ }^{77}$ However, he also maintains that there have always been originating events of one sort or another in the universe. Moreover, the perpetuity of God's creative activity requires this. While there is no one thing in the universe that is eternal, the species or genus of originating events is eternal. ${ }^{78}$ The shaykh gives a number of examples to tease out the difference between an eternal species and its originating individuals. In some cases, individuals and species are qualified in a similar way. When, for example, all of the individuals of a species are qualified as existent, possible or nonexistent, the species itself must also be so qualified. Ibn Taymiyya cites the following example: "If each one of the Zanj is black, then the whole group is black." ${ }^{79}$ However, the individuals of a species do not necessarily have to share the same attributes as the species itself, as when individuals are qualified by origination and passing away while the species as a whole is perpetual. As an example of this distinction, Ibn Taymiyya cites quranic verses on the provision of Paradise, "Its food is eternal, and its shade" (Q. 13:35), and, "Truly, this is our provision which has no end" (Q. 38:54). What is perpetual here is the species of provision and not the individual units that go out of existence. No one piece of food is perpetual. The shaykh probes this distinction further by observing that

73 Minhāj, 1:200-1/1:51.

${ }^{74}$ Minhäj, 1:199/1:51, 1:235-6/1:61-2, 1:374-380/1:103-4.

${ }^{75}$ Minhāj, 1:236/1:62.

76 Minhäj, 1:197-9/1:50, 1:276-7/1:74. In Minhāj, 1:239-296/1:63-80, Ibn Taymiyya treats Ibn Sinnäs idea that an act need not be preceded by nonexistence in a refutation of ten proofs for it set out by Fakhr al-Dīn al-Rāzì, Kitäb al-mabāhith al-mashriqiyya (Hyderabad: Maṭba'at majlis dā’irat al-ma ārif al-nizāmiyya, 1343/1924), 1:485-492.

${ }_{77}$ Minhäj, 1:301-3/1:82-3, 1:384/1:107.

${ }^{78}$ Minhāj, 1:232-3/1:60-1.

79 Minhāj, 1:430/1:119. 
the attributes of individual parts of something may not qualify the whole and vice versa. Certain parts of a house, a human being or a tree may be long or wide, but this does not necessarily mean that every part is long or wide. If one says that this day or that prayer is long, it does not mean that all parts of this day or that prayer are long. Similarly, the origination and passing away of individual units does not necessarily entail the origination or passing away of the whole species of originating events. ${ }^{80}$

If the species of originating events is eternal, we may ask what Ibn Taymiyya believes existed prior to this present world. He asserts that the celestial sphere was originated in time, and he does not rule out the possibility that there were other celestial spheres prior to this one. ${ }^{81} \mathrm{He}$ also indicates that this present world was created out of pre-existing matter. He explains that Aristotle was the first to claim that the celestial sphere was eternal, but he notes that the philosophers before Aristotle believed "that this world was originated, either in its form (süra) only or in its form and matter (mädda). And most of them maintain the priority of the matter of this world over its form." 82

Ibn Taymiyya shows that the revealed tradition also indicates that other things existed before the creation of this world and that this world was created out of pre-existing matter. In support of this, he cites the following quranic verses: "[God] created the heavens and the earth in six days, and His Throne was on the water" (Q. 11:7), and, "He rose toward heaven when it was smoke, and He said to it and to the earth, 'Come under coercion or obediently'. They both said, 'We come obediently"' (Q. 41:11). In this regard, he also notes two hadiths: "Truly, God determined the determinations of created things before $\mathrm{He}$ created the heavens and the earth by fifty thousand years, and His Throne was on the water," ${ }^{83}$ and, "God was, and there was nothing before Him. And His throne was on the water. And He wrote everything in a Reminder. Then He created the heavens and the earth." ${ }^{84}$ The shaykh says that traditions from the Companions and the Followers affirming God's creation of the heavens from water vapor, that is, smoke, are abundantly transmitted (mutawātir). ${ }^{85}$

${ }^{80}$ Minhāj, 1:426-431/1:118-9.

${ }^{81}$ Minhāj, 1:220/1:57 and 1:385/1:107.

${ }^{82}$ Minhāj, 1:360/1:100. Unfortunately, Ibn Taymiyya does not provide names of any pre-Aristotelian philosophers.

${ }_{83}$ Muslim, 4797, Al-Qadar, Hijāj Ādam wa Mūsā.

${ }^{84}$ Bukhārī, 6868, Al-Tawhīed, Wa kāna 'arshuhu 'alā al-mā'... The variant readings of this hadith are discussed in Hoover, "Perpetual Creativity," 300-1.

${ }_{85}$ Minhāj, 1:360-1/1:100. Ibn Taymiyya's intepretation of the quranic verses listed here resembles that of Ibn Rushd in Kitäb faṣl al-maqäl, ed. George F. Hourani (Leiden: E.J. Brill, 
In interpreting these texts, Ibn Taymiyya reports debate over whether God first created the Pen-as in the hadith, "The first thing God created was the Pen," ${ }^{86}$ - or the Throne. The shaykh explains that God most likely created the Throne first. Then, the Pen was the first thing created of this world for the purpose of writing down the determinations fifty thousand years before the creation of the heavens and the earth. He adds that there must have been time prior to the creation of this world so that God would have had some measure by which to say that He had created it in six days. ${ }^{87}$ Ibn Taymiyya also notes that the Torah says much the same thing: the earth was covered with water and the wind was blowing over it before God created the heavens and the earth in several days' time (Genesis 1:1-2). He then cites some unnamed scholars among the People of the Book to the effect that this means that God created from matter and in time. ${ }^{88}$

The shaykh does not discuss whether the Throne itself, as the first created thing, was also created from pre-existing matter. The logic of God's perfection would appear to entail that there has always been one created thing or another, even before the Throne. Yet, the shaykh does imply that there was in some sense a first created thing by asserting that it is in God's perfection that $\mathrm{He}$ is prior to all others in every respect. ${ }^{89}$ Although Ibn Taymiyya does not himself suggest the possibility, we might imagine that the infinite regression of originating events in this world approaches God's pre-eternity asymptotically. The regression grows ever closer to pre-eternity but never touches it, and, so, it may still be said that God is prior to every originating event in time.

\section{Refutation of Kaläm Arguments against an Infinite Regress}

Although most of Ibn Taymiyyas polemic in the first volume of Minhäj uses the principle of preponderance or originating causality to reduce the Kalām position of creation ex nibilo to absurdity, he also seeks to undermine positive Kalām arguments against the eternity of the world. ${ }^{90}$ Refutation of these proofs is especially important to Ibn Taymiyya in order to open the door to

1959), 19-21; in trans. as Averroes, On the Harmony of Religion and Philosophy, trans. George F. Hourani, (London: Luzac, 1961), 55-7.

${ }^{86}$ Abū Dāwūd, 4078, Al-sunna, Fī al-qadar; Al-Tirmidhī 2081, Al-Qadar 'an Rasūl Allāh, Mā jā̀a fì al-riḍā bi-l-qaụāà.

${ }^{87}$ Minhäj, 1:361-2/1:100. On the matter of time before the creation, see also Minhäj, $1: 172-3 / 1: 43$.

${ }_{88}$ Minhāj, 1:363/1:100.

${ }^{89}$ Minhāj, 1:419/1:117.

${ }^{90}$ Minhājj, 1:432-438/1:120-2. Cf. Iräda, MF 8:152-3. 
the possibility of an infinite regress of causes or wise purposes in God's will. The main Kalām proofs are based on two arguments for the impossibility of an actual infinite stemming from the sixth-century philosopher John Philoponus (d. ca. 570). The Kalām theologians conclude that, since any actual infinite is impossible, the world must have a beginning. ${ }^{91}$

One of John Philoponus's arguments asserts that the passing of time increases the number of past events. However, infinites cannot be increased. So past events cannot be infinite. ${ }^{92}$ From the notion that an infinite cannot be increased, Ibn Sinnā, with precedents in the philosopher al-Kindī (d. ca. 252/866), developed the application (tatbiq) argument to show that magnitudes must be finite. The argument may be summarized as follows. Suppose that a magnitude $\mathrm{A}$ is finite on one end and infinite on another. Some length is added to the finite end of A yielding a new magnitude B. The finite end of B is then "applied" to the finite end of A, and it is noted that the two infinite ends no longer match. This is absurd and disproves the possibility of infinite magnitudes. Ibn Sinā does not use this argument against an infinite regression of causes and effects, but the Kalām theologian Fakhr al-Dīn al-Rāzī does, and al-Rāzī’s form of the argument is what Ibn Taymiyya refutes in Minhajj. ${ }^{93}$

Ibn Taymiyya presents al-Rāzì’s argument as follows. If the series of originating events from the time of the Hijra to infinity is compared with the series of originating events from the time of the Flood of Noah to infinity, the one series will be longer than the other by the difference between the Flood and the Hijra. Since disparity between two infinites is impossible, an infinite series of originating events is impossible. ${ }^{94}$ For Ibn Taymiyya, such a disparity is not impossible. From the Flood to future infinity is greater than from the Hijra to future infinity. Likewise, what is between the Hijra and past infinity is greater than what is between the Flood and past infinity even though both lack a beginning. The disparity, however, occurs only between the two finite ends, in this case between the Flood and the Hijra. It does not

91 On Philoponus and the adoption of his arguments against an actual infinite into the Kalām tradition, see Davidson, Proofs for Eternity, 86-94 and 117-127; and Harry Austryn Wolfson, The Philosophy of the Kalam (Cambridge, MA: Harvard University Press, 1976), 410-434.

92 Davidson, Proofs for Eternity, 88-9.

93 Davidson, Proofs for Eternity, 125-7; and al-Rāzì, Arba' in, 34. On the origins of the application argument, see also Husâm Muhî Eldîn al-Alousï, The Problem of Creation in Islamic Thought: Qur'an, Hadith, Commentaries, and Kalam (Baghdad: The National Printing and Publishing Co., 1965), 304-313.

${ }_{94}$ Minhäj, 1:432/1:120. 
occur in the infinite ends. Infinity itself is not subject to specific measurement such that one infinite may be said to be commensurate to, greater than, or less than another infinite. To illustrate his point, Ibn Taymiyya compares the concept of infinity to multiplicity. The numbers $1,10,100,1000$, etc. all share in multiplicity, but this does not mean that they all have the same value. Likewise, infinites may entail diverse values from one perspective, yet all share in infinity from another. ${ }^{95}$ Ibn Taymiyya also recounts Ibn Sinās refutation of the Kalām use of the application argument. In Ibn Sinnăs view, the application argument against an infinite regress of causes and effects is just a mental exercise. It does not correspond to anything in actuality because everything in the past no longer exists and everything in the future does not yet exist. The application argument against an actual infinite is only valid for what actually exists. ${ }^{96}$

The second argument from John Philoponus exploited by the Kalām tradition maintains that an infinite cannot be traversed. This being the case, something in the present cannot be preceded by an infinite regression of events. ${ }^{97}$ In Minhāj Ibn Taymiyya refutes the defense that al-Juwayni gives for this argument in his Kitāb al-irshäd. ${ }^{98}$ Al-Juwaynī argues that positing an originating event preceded by originating events without beginning is like saying to someone, "I will not give you a dirham unless I give you a dinar before it, and I will not give you a dinar unless I give you a dirham before it." Under these conditions, al-Juwaynī concludes that no dirham or dinar will ever be given. He argues that the only way that this statement can be turned into a valid condition is to say, "I will not give you a dinar unless I give you a dirham after it." ${ }^{\prime 9}$

Rephrasing al-Juwayni’s formulas slightly, Ibn Taymiyya agrees that it is possible to say, "I will not give you a dirham unless I give you a dirham

\footnotetext{
${ }^{95}$ Minhāj, 1:432-4/1:120.

${ }^{96}$ Minhāj 1:434-5/1:120-1. For the attribution of this argument to Ibn Sinnā, see Davidson, Proofs for Eternity, 128-9. Davidson, Proofs for Eternity, 89, 122, also distinguishes a third argument from John Philoponus that carried over into the Kalām tradition even though it is merely a variation of the second. Rather than assume that an infinite cannot be added to, it assumes that an infinite cannot be multiplied. The Kalām theologians argued that the revolutions of the planets could not be infinite because it was known the planets revolved at different speeds. If the planets had revolved from eternity, each planet would have revolved an infinite number of times proportionally different from the other planets. This was rejected as absurd. Ibn Taymiyya does not treat this argument nor does he need to since he permits infinites that are not commensurate.

${ }^{97}$ Davidson, Proofs for Eternity, 87-8, 119-120.

${ }_{98}$ Minhāj, 1:435-6/1:121.

99 Imām al-Haramayn 'Abd al-Malik b. 'Abd Allāh al-Juwaynī, Kitāb al-irshād ilā qawāṭi' al-adilla fì ușül al-i'tiquàd (Beirut: Dār al-Kutub al-'ilmiyya, 1416/1995), 16.
} 
after it." However, he believes that it is wrong-headed and impossible to say, "I will not give you a dirham until I give you a dirham before it," because this negates that something will happen in the future until the same thing happens in the future. The argument as stated is invalid, and does not deal with an infinite regress in the past. The shaykh believes that the statement should instead read, "I have not given you a dirham unless I have given you a dirham before it." This is a negation of a past event until another past event has occurred prior to it, and this is possible. So, by correcting al-Juwaynîs formulation to make it properly applicable to an infinite regress in the past, Ibn Taymiyya believes that he has eliminated any difficulty that al-Juwaynîs argument might pose for an infinite regress of events. ${ }^{100}$

By refuting the Kalām arguments against an actual infinite, Ibn Taymiyya clears the way for the possibility of an infinite regression, and, as we have seen, he upholds an endless chain of originating events into the past and into the future. However, he clarifies in Minhäj that he admits only an infinite regress of effects (äthār), not an infinite regress of causes, creators, agents and originators. Causes and agents in an infinite regress are all possible, originated and nonexistent in themselves and must be given existence by another. In fact, he notes, the longer the chain of these agents becomes, the greater is its need for an agent who is "only existent in Himself, necessarily existent, not admitting nonexistence, eternal and not originated." ${ }^{101}$ Yet, Ibn Taymiyya does not explain how this eternal and necessary First Cause gives rise to a regress of temporally originating events.

Summing up the present discussion, Ibn Taymiyya agrees with the Ash'aris that wise purpose and causality in the will of God lead to an infinite regress, but he denies that this constitutes grounds to reject God's rationality. The shaykh refutes the arguments for the impossibility of an actual infinite that the Kalām theologians use to disprove the eternity of the world, and he maintains that the perfection of God requires that God create and will originating events from eternity. Using the principles of preponderance and originating causality, he deconstructs the cosmologies of the Kalām theologians and philosophers such as Ibn Sīnā. He argues against the philosophers that originating events in the world cannot arise from an eternal complete cause and against the Kalām theologians that events cannot originate from an eternal divine will. Rather, he maintains that there is an infinite regress

${ }^{100}$ Ibn Taymiyya gives al-Juwaynī's argument fuller treatment in $D a r^{\prime}, 9: 186-8$, and concludes that al-Rāzì and al-Âmidì had already detected the argument's weakness.

${ }^{101}$ Minhäj, 1:436-8 (quote on 437)/1:121. 
of God's willings corresponding to the originating events that God creates in the world.

\section{Ibn Taymiyya on God's Voluntary Acts Subsisting in God's Essence}

Besides an infinite regress, a key Ash'arī objection to wise purpose in the will of God is that it makes God a substrate for originating events. In the first volume of the edited Minhāj, Ibn Taymiyya traces this objection's root to the Jahmī argument that God's attributes must subsist outside of Him because originating events (i.e. the attributes) only subsist in originating bodies and God is not an originating body. ${ }^{102} \mathrm{Ibn}$ Taymiyya himself does not take God to be an originating body, but he rejects as fallacious the claim that originating events subsist only in originating bodies. Despite this, the shaykh is reticent to affirm explicitly that origination, much less time, subsists in God's essence. Although he does on rare occasion allow that originating events subsist in God, he typically states the doctrine in other terms. ${ }^{103} \mathrm{He}$ hints at why in Minhāj.

Ibn Taymiyya argues in Minhäj that the Mu'tazilīs and their Shîi î followers must admit originating events in God because they say that God became an agent after $\mathrm{He}$ was not one, that is, $\mathrm{He}$ was subject to a change in state when He began to create the world. The shaykh adds that all groups, including the philosophers, must admit this doctrine, an argument Fakhr al-Dīn al-Rāzī makes as well without working out its implications in his theology. ${ }^{104}$ Perhaps with some exaggeration, Ibn Taymiyya goes on to claim that, in addition to Abū al-Barakāt, the pre-Aristotelian philosophers, the Karrāmīs and others, the mainstream Sunnī tradition does in fact uphold this doctrine: "As for the great majority of the People of the Sunna and the Hadith, they speak of it or its meaning, even if some of them choose to speak only in legislated terms (al-alfäzal-shar iyya) and some of them express the legislated meaning with expressions indicating it." ${ }^{105}$ Here, Ibn Taymiyya draws a distinction between those who use the technical term 'originating events' to identify this doctrine and other scholars who seek to speak of the doctrine in terms

\footnotetext{
102 Minhāj, 1:311/1:85.

103 In Furqān, MF 13:156, Ibn Taymiyya states briefly but explicitly that the Salaf uphold originating events subsisting in God.

104 Al-Rāzì, Al-Mațälib al-'äliyya, 2:106-7. For further discussion of this argument in al-Rāzī, see Hoover, "God Acts by His Will and Power."

${ }_{105}$ Minhāj, 1:421-3/1:117-8 (quote on 1:422-3/1:118).
} 
closer to the authoritative texts. It seems apparent that Ibn Taymiyya takes the latter path since he studiously avoids 'originating events' in his own doctrinal affirmations and speaks instead of God's attributes or acts which are 'voluntary' (ikhtiyäriyya). While the very term ikhtiyarriyya does not appear in the Qur'an or the Hadith, other forms of the verb ikhtära (to choose), from which it is derived, do occur. ${ }^{106}$

Ibn Taymiyya's Minhäj discussion of Ibn Sinnās denial of change in God's essence illustrates his typical idiom in this respect. Ibn Taymiyya argues that when God the Agent remains in one state, there is no way to explain the difference and origination that arise in the world. While there are enacted things, there is no act to bring them into existence. Rooting himself in the authority of the prophets, the Salaf and unnamed pre-Aristotelian philosophers, Ibn Taymiyya argues that there must be voluntary acts in God's essence in order for change to arise in the world. ${ }^{107}$ To deny acts subsisting in God is to deny that $\mathrm{He}$ is acting and originating. ${ }^{108}$ Rather, he affirms, "The Lord must inevitably be qualified by acts subsisting in Him one after another... like His will subsisting in His essence, His words subsisting in His essence, and His voluntary acts subsisting in His essence."109

With this, Ibn Taymiyya leaves aside the ideal of the philosophers and the Kalām theologians that God is timelessly eternal and replaces it with a God whose essential perfection consists in perpetual dynamism. In this theology, the question of the origin of the causes or wise purposes giving rise to God's acts of will poses no difficulty because they are simply prior and posterior acts of God extending backwards and forwards forever in God's eternal activity. It remains to address how Ibn Taymiyya conceives God's self-sufficiency. An infinite regress of God's acts implies an infinite regress of the objects of those acts. If then there has always been one world or another, in what sense is God sufficient apart from the worlds?

106 For example, "I [i.e. God] have chosen you (ikhtartuka). So, listen to what is revealed" (Q. 20:13). In Ikhtiyariyya, MF 6:217-267, a treatise devoted to the active quality of God's attributes, Ibn Taymiyya also rejects the Kalām position and upholds the substance of originating events subsisting in God's essence while avoiding the very words and speaking instead of God's voluntary attributes. For analysis of Ikhtiyäriyya and further contextualization of Ibn Taymiyya's position in the tradition of later Kalām, see Hoover, "God Acts by His Will and Power." Ibn Taymiyya, MF 8:380, also speaks of "voluntary matters (al-umūr al-ikhtiyāriyya)" subsisting in God's essence.

107 Minhāj, 1:334-6/1:91-2.

${ }_{108}$ Minhāj, 1:352-3/1:97. See Irāda, 8:149-151, for polemic against the Mu'tazilis in this regard.

109 Minhāj, 1:327/1:89. Cf. Minhäj, 1:336/1:92 and 3:191-6/2:37-8. 


\section{Ibn Taymiyya on God's Sufficiency apart from the Worlds in the Exercise of Wise Purpose}

In order to guarantee God's sufficiency apart from the world, the Ash'arīs deny that God acts for wise purposes lest He be perfected (mustakmal) by those purposes and imperfect beforehand. The Mu'tazilis affirm that God acts on account of wise purposes, but, again to protect God's sufficiency, these are disjoined from God and yield a return of beneficence and profit only to creatures. Ibn Taymiyya adopts a decidedly different and apparently paradoxical stance. He asserts God's sufficiency (ghinā), but he also maintains that God acts on account of wise purposes that return to God. Qudra, a treatise on God's power, contains a clear and concise statement of the shaykh's view:

God has a wise purpose in everything that He creates. As He said, "The handiwork of God who perfected everything" (Q. 27:88), and He said, "Who made good everything He created" (Q. 32:7). He-Glory be to Him-"is sufficient apart from the worlds" (Q. 3:97, 29:6). The wise purpose includes two things. First is a wise purpose that returns to Him ( $t a^{\prime} \bar{u} d u$ ilaybi), which He loves and with which $\mathrm{He}$ is well pleased. The second [returns] to His servants, which is a blessing for them at which they rejoice and in which they take pleasure. This is in things commanded and in things created. ${ }^{110}$

With respect to things commanded, Ibn Tamiyya goes on in Qudra to explain that God loves obedience and rejoices when His servants repent. There is happiness in this for servants as well: "In what He has commanded of acts of obedience is its praiseworthy end which returns to Him and to His servants. In it, He has a wise purpose, and His servants have a mercy." ${ }^{111}$ The same applies to created things: "Likewise, what He created He created for a wise purpose which returns to Him and which He loves, and for servants He created it to be a mercy from which they profit." ${ }^{12}$

Taken by other concerns, Ibn Taymiyya does not respond to Ash'arī and Mu'tazili objections against his view of wise purpose in Qudra, but he does so in Iräda and Minhäj. In Iräda the shaykh identifies contradiction in the Mu'tazilī view. The Mu'tazilīs, he argues, maintain that God created and

\footnotetext{
${ }_{110}$ Qudra, MF 8:35-36.

111 Qudra, MF 8:36. Ibn Taymiyya, Qudra, MF 8:39, also explains that God created servants to worship, praise, laud and glorify him, and he devotes most of the rest of Qudra to an explanation of "I did not create the jinn and humankind except that they might worship Me" (Q. 51:56).

${ }_{112}$ Qudra, MF 8:37.
} 
commanded creatures for the wise purpose of showing them beneficence and giving those who are legally obligated their reward. However, they claim that no judgment ( $\mathrm{bukm})$ returns to God for His beneficence, and they make God indifferent to His own acts by asserting that His acts do not subsist in His essence. But, Ibn Taymiyya continues, someone who is beneficent is praised, and it is the judgment that returns to the beneficent that makes beneficence praiseworthy. Moreover, someone who is beneficent is not indifferent to his acts: "The generous soul rejoices, is glad and takes pleasure in the good that proceeds from it to another." ${ }^{\prime 13}$ Conversely, it is irrational that someone not seek gain through his acts: "Anyone who commits an act in which there is neither pleasure, nor benefit nor profit for himself in any respect, neither sooner nor later, is aimless, and he is not praised for this." ${ }^{114}$ Thus, the Mu'tazilis end up in contradiction by portraying God as aimless in the very act of trying to protect Him from the aimlessness of the Ash'arī position.

Ibn Taymiyya's argument gives short shrift to disinterested beneficence and makes a measure of self-interest intrinsic to what constitutes rational and praiseworthy action. Implied, but left unstated, is that God is perfect and praiseworthy because of the rationality in the things that $\mathrm{He}$ does. From this, it could be understood that God acts rationally in order to elicit His servants' praise for the sake of His perfection. However, this would run counter to what we find for example in a blustery passage on God's sufficiency in Nubuwwāt, Ibn Taymiyya's book on prophecy. He seeks to allay Kalām fears that love, wise purpose and the like lead necessarily to God's need for His servants by denying that God's servants can profit Him or that $\mathrm{He}$ needs their profit. Likewise, God has no need to fear creatures. Unbelievers cannot harm Him, and it does Him no harm when people fail to keep His commands. ${ }^{115}$ The shaykh's defense here offers no theological analysis; it is limited to negations.

Ibn Taymiyya does more substantial theological work on God's sufficiency in Iräda and Minhäj by considering the all-comprehensive character of God's acts instead of their ethical quality. Here is how the shaykh replies briefly in the first volume of Minhäj to the Ash'ari charge that wise purpose in God's will implies that God is perfected by another and was imperfect beforehand:

\footnotetext{
113 Irāda, MF 8:89.

114 Iräda, MF 8:89-90.

115 Nubuwwāt, 135-6.
} 
When [God] is powerful over [and] the agent of everything, He does not need another in any respect. On the contrary, the causes enacted are objects of His power and will. God-Exalted is $\mathrm{He}$-inspires His servants to invocation and $\mathrm{He}$ answers them. He inspires them to repentance, and He rejoices at their repentance when they repent. He inspires them to deeds and rewards them when they perform deeds. It will not be said that the creature impacts the Creator or makes Him act to answer, reward and rejoice at their repentance. $\mathrm{He}-$ Glory be to Him-is the Creator of all of that. To Him is sovereignty, and to Him is praise. He has no associate in anything of that, and in it $\mathrm{He}$ has no want of another. ${ }^{116}$

What Ibn Taymiyya leaves unsaid is that he does not accept the presupposition provoking the Ash'arī objection. The Ash'arīs posit creation as an utterly free and arbitrary act of God that could just as well not have occurred without any loss to God being God. If God acts or creates for a purpose, this detracts from His freedom by making the act essential to His perfection. For Ibn Taymiyya, however, God's creative activity is not free in the sense intended by the Ash'arīs. Instead, perpetual creativity is intrinsic to God's perfection, and the existence of the genus of created things follows necessarily from this. What would detract from God's perfection is someone else controlling or helping God in what He wills to create. God's sufficiency and lack of need consist in God alone creating all things with no one else helping Him or influencing $\mathrm{Him}$ in that. ${ }^{117}$

Ibn Taymiyya responds to the Ash'arī objection more comprehensively in Iräda in five points. Leading up to this is a discussion of love that sets the theological context. On the authority of texts from the Qur'an and the Hadith, Ibn Taymiyya argues that God's servants should love God in Himself and love other things only for God's sake. Conversely, God loves His servants who believe in Him and do what He loves. Much as we find in Ibn Sīnā, Ibn Taymiyya locates the source of God's love for His servants in God's love for Himself: "What God loves of worship of Him and obedience to Him follows from love for Himself, and love of that is the cause of [His] love for His believing servants. His love for believers follows from love for Himself." 118 That is, God's love for Himself is primary, and God's love for

${ }^{116}$ Minbajj, 1:421/1:117. The translation, “...that the creature impacts the Creator or makes Him act...," follows the text of Minhäj which reads: inna al-makhlūq aththara fi alkhäliq aw jáalahu fä́ ilan. MinhäjB reads somewhat differently: inna li-l-makblüq atharan fì al-khäliq já alahu fä́ilan.

117 See similar arguments at MF 8:379.

118 Iräda, MF 8: 140-4 (quote on 144). Similarly in Nubuwwāt, 111, Ibn Taymiyya writes, "The Lord-Exalted is He-loves Himself, and among the necessary concomitants of His love of Himself is that it is a love willing what He wills to do. What He wills to do, He wills 
human beings follows on from that secondarily. On this basis, Ibn Taymiyya argues comparatively that God's self-love, self-praise and self-laudation so greatly exceed human love, praise and laudation of God that God has no need of them. More decisively, however, the shaykh leaves the human vantage point aside completely and adds that God has no need because it is He who creates the love and good deeds of His servants:

[God] is the Sufficient-in-Himself (al-ghani bi-nafsibi). He does not need anyone else. Even more, everything other than Him is in want of Him ... When He rejoices at the repentance of the repenting, loves whoever draws close to Him with supererogatory deeds, is well pleased with the earliest predecessors and such like, it is not permissible to say that He has want of another in that. $\mathrm{He}$ is not perfected by another. It is He who created them, and it is $\mathrm{He}$ who guided them and helped them so that they did what He loves, is well pleased with and rejoices at. ${ }^{119}$

As in the argument cited from Minhäj above, Ibn Taymiyya here preserves God's sufficiency not by making the world arbitrary—as the Ash'aris do-but by crediting all that occurs within it to God's creative acts. One might ask what role volition plays in the shaykh's understanding of human agency, but answering this question must await Chapter Four. Continuing on in Iräda, Ibn Taymiyya identifies the argument above as that of "the great majority who affirm in [God's] acts a wise purpose which is linked to Him, which $\mathrm{He}$ loves, with which $\mathrm{He}$ is well pleased, and for the sake of which He acts." 120

After this, the shaykh takes up his five point response to the Ash'arī objection that this makes God "perfected by another and imperfect prior to that." ${ }^{21}$ Four of the five points made in Iräda are arguments from reason. The first point states that only someone perfected by his acts is rational. We have already seen this premise at work in Ibn Taymiyya's polemic against the Mu' tazili notion that God acts for wise purposes that do not return to Him. The second point briefly sets aside the Ash'arī theology of a God who acts without cause: a God not able to act for a wise purpose would be imperfect. This is expanded in the fifth point where the shaykh explains that reason knows that someone able to bring events into existence for a wise purpose is more perfect than someone not able to do that. Probably with the philoso-

\footnotetext{
for an objective (ghäya) that He loves. Love is the final cause (al-illa al-ghä iyya) because of which everything exists." Although not explicitly stated, the context indicates that the final cause here is God's very essence. My translation differs somewhat from that of Bell, Love Theory, 80, who quotes it for other purposes.

${ }_{119}$ Iräda, MF 8:145.

${ }^{120}$ Iräda, MF 8:145.

121 Iräda, MF 8:146-7 (quote on 146).
} 
phers in mind, he adds that it does not matter that these events originate temporally and are not eternal. In fact it is of the perfection or character of an originating event not to exist prior to its origination. In his fourth point, and arguing in a similar vein, Ibn Taymiyya takes on the Ash'arī complaint that God's acting for a cause makes God imperfect prior to His alleged perfection. The shaykh replies that perfection is the existence of something only when wise purpose requires. Imperfection is its existence at other times. Thus, imperfection is not the nonexistence of something as such, but only its absence when it should exist. Ibn Taymiyya notes that God is ascribed with both negative and positive attributes, both of which imply His perfection, and greater perfection is not always attained through addition.

The third point has been saved for last because it is not properly a rational argument but a clarification. Ibn Taymiyya explains that God is not perfected by another, as the Ash'arīs surmise. Rather, God is perfected by His own will and power without help from any other. God's sufficiency is brooking no rivals in the act of creation; it is not indifference to creation as such. If it should still be thought that God somehow gains something from others through His acts, he adds, "When it is said that He is perfect through (kamula bi) His act in which He does not need anyone else, it is as if it were said that $\mathrm{He}$ is perfect through His attributes or perfect through His essence." ${ }^{122}$ From this angle, God's acts are just as constitutive of His perfection as His attributes and essence. God's activity is a necessary concomitant of God's perfection, and in no way does God acquire perfection through His acts. ${ }^{123}$

\section{Conclusion}

Ash 'arī objections to rationality in God's will present a major obstacle to articulating a theodicy, and Ibn Taymiyya must face these objections squarely in order to carve out intellectual space for his own view. The shaykh's insistence that God acts rationally on account of wise purposes or causes in a self-interested sense strongly suggests that God needs creatures to manifest His perfection. The shaykh thus appears to fall afoul of the Ash'arī charge that causality in the will of God endangers God's self-sufficiency. Ibn Taymiyya sidesteps the Ash'ari allegation by explaining that it is God who creates

122 Irāda, MF 8:146.

123 Cf. Kasb, MF 8:387, which is translated below in Chapter Four, n. 122. 
both creatures and their responses. God is sufficient in the sense that $\mathrm{He}$ needs no help in creating all that is in the world. The shaykh also employs the Avicennan notion that while the world is a necessary concomitant of God's perfection and self-love it is not essential to who God is. God has no need of the world. He loves, praises and lauds Himself primarily, and from that flows the world only secondarily, even if necessarily.

The Ash' arīs also argue that causality in God's will entails an infinite regress and subjects God to temporal origination, both of which the Ash'arīs take to be impossible. In response, Ibn Taymiyya refutes Ash'arī arguments against an infinite regress and turns perpetual origination in God's essence into a virtue of God's perfection. However, the shaykh prefers to speak not technically of originating events subsisting in God's essence but more scripturally of God's voluntary attributes and acts, which He exercises by His will and power. This is much the same as when Ibn Taymiyya indicates causality in God's will with the term wise purpose ( hikma) instead of purpose (gharad) in order to avoid negative connotations attached to the latter term in everyday speech. In sum, God in His perfection has been willing and creating originated things of one kind or another for wise purposes from eternity by means of His will and power.

This perpetually dynamic vision of God's essence sets Ibn Taymiyya apart from much, perhaps all, of the preceding Islamic philosophical and theological tradition and especially from fellow optimist Ibn Sinna. The shaykh rejects the Kalām doctrine that creation had a definite beginning, and he jettisons Ibn Sinnäs emanation cosmology and timeless God. However, he retains the necessity of optimal productivity inherent in Ibn Sinā’s notion of God. Ibn Taymiyya portrays God's creation of the world as voluntary and dynamic, but this dynamic and voluntary creativity is nonetheless a necessary concomitant of God's essential and self-sufficient perfection. 


\section{GOD'S CREATION AND GOD'S COMMAND}

\section{Ibn Taymiyya's Creation/Command Hermeneutic}

If God is the wise Creator of everything that occurs in the world, how does Ibn Taymiyya account for human agency and responsibility? The following chapter focuses directly on how God creates human agency. The present chapter examines how the shaykh relates God's legislation, which imposes human obligation and responsibility, to God's all-encompassing creation. As noted in the last chapter, Joseph Bell shows how Ibn Taymiyya attacks alJuwaynī for equating God's love and good pleasure with God's creative will (irāda khalqiyya) of all things. According to Ibn Taymiyya, God does not love the unbelief that He creates. Rather, God loves and is well pleased with obedience to His legislative will (iräda shar iyya). God only creates unbelief for a wise purpose that he loves. God does not love unbelief, but God loves the wise purpose for which it is created.

While Bell has well described the core of Ibn Taymiyya's doctrine, it remains to display the variety of ways in which the shaykh expresses it. The terms 'creative will' and 'legislative will' are part of a creation/command hermeneutic that Ibn Taymiyya employs to interpret a wide range of quranic and theological terms. Equivalent to God's creation are God's lordship, inspiration, determination, decree and ontological will. Corresponding to God's command are God's divinity, love, good pleasure and religious will, as well as the distinction between piety and immorality. Additionally, Ibn Taymiyya does not always address the conundrum posed by creation and command with God's love for his wise purpose. Frequently he simply affirms wise purpose, justice or mercy in God's creation. On a few occasions, however, he does suggest images or similitudes to render the non-coincidence of creation and command more plausible.

Besides surveying diverse ways that Ibn Taymiyya affirms creation and command, the present chapter gives much space to his attendant polemic against Kalām theologians, Sufis and skeptics. However, the shaykh's critique of Sufism, which grows out of his concern to give creation and command 
each their due, is much more extensive than can be examined here. ${ }^{1}$ The discussion below is limited to indicating some major directions this takes. More detailed treatment of Ibn Taymiyya's criticism of Sufism may be found elsewhere. ${ }^{2}$

\section{Ibn Taymiyya's Classification of Errors in Creation and Command}

\section{A Typology of Errors}

In several theodicean texts, Ibn Taymiyya sets out a four-fold typology on creation and command that classifies his polemical opponents and identifies his own view. ${ }^{3}$ Although not complete, the following passage translated from Tadmuriyya is fairly typical. Four major positions are identified with the appellations "Majūsiss," "Mushrikīs," "Iblīsiss," and "People of Guidance and Success." Following the translation, the first three positions will be clarified and augmented from the shaykh's other instances of the typology and related polemic.

It is well known that it is obligatory to believe in God's creation (khalq) and His command (amr), His decree ( $q a d \vec{a})$ and His legislation (shar ${ }^{r}$. The mis-

\footnotetext{
${ }^{1}$ Much of Ibn Taymiyya's thinking on Sufi matters is found in volumes 1, 2, 10 and 11

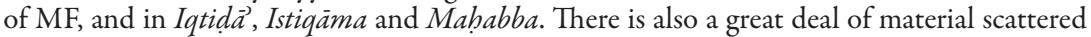
throughout his other writings.

${ }^{2}$ For Ibn Taymiyya's various critiques of Sufi speculation and popular religious practices, see Alexander D. Knysh, Ibn 'Arabi in the Later Islamic Tradition: The Making of a Polemical Image in Medieval Islam (Albany, NY: State University of New York Press, 1999), 87-111, with corrections to the analysis of Ibn Taymiyya in the review by Jon Hoover in Islam and Christian-Muslim Relations 10:3 (Oct. 1999): 392-4; Muhammad Umar Memon, Ibn Taimiya's Struggle against Popular Religion: With an Annotated Translation of his Kitāb iqtiḍāas aș-ṣirāt al-mustaqīm mukhālafat aṣhāb al-jahīm (The Hague: Mouton, 1976); Michel, A Muslim Theologian's Response to Christianity, 5-14, 24-39; Jean R. Michot, Musique et danse selon Ibn Taymiyya, Le livre du Samâ' et de la danse (Kitâb al-Samât wa l-Raqș) compilé par le shaykh Muhammad al-Manbijî (Paris: J. Vrin, 1991); P. Nwyia, "Une cible d'Ibn Taimîya: Le moniste al-Tilimsânî (m. 690/1291)," Bulletin d'Etudes orientales 30 (1978): 127-145; Niels Henrik Olesen, "Étude comparée des idées d'Ibn Taymiyya (1263-1328) et de Martin Luther (1483-1546) sur le culte des saints," Revue des Etudes Islamiques 50 (1982):175-206; and Niels Henrik Olesen, Cultes des Saints et Pélerinages chez Ibn Taymiyya (Paris: Paul Geuthner, 1991).

${ }_{3}$ Ibțäl, MF 2:300-4; Fì Fușūs, MF 2:409-411; Tadmuriyya, MF 3:111-2; Qadariyya, MF 8:256-261; and $T_{\bar{a}}{ }^{-} a$, MF 8:444-6. Cf. Minhäj, 3:82/2:9-10. The following discuss the same ideas although not in the form of a tidy typology: Wäsitityya, MF 3:148-150; Iräda, 8:97-117; Sáäda, MF 288-9; Ihtijiāj, MF 8:303-370; Jabr, MF 8:449-478; Furqān, MF 13:211-229; Hasana, MF 14:347-359; Shams, MF 16:230-248; and Minhäj, 3:75-8/2:7-8.
} 
guided people who delve into determination (qadar) have divided into three sects: Majūsīs, Mushrikīs and Iblīsīs.

The Majūsis are those who gave the lie to the determination of God even if they believed in His command and His prohibition. The extremists among them denied the [fore-]knowledge [of God] and [pre-]writing [of human acts]. The moderates among them denied the generality of His will (mash $\vec{i} a$ ), His creation and His power (qudra). These are the Mu'tazilis and those who agree with them.

The second sect is the Mushrikis who acknowledged decree and determination and denied command and prohibition. He-Exalted is $\mathrm{He}$ - said, "Those who gave associates [to God] will say, 'If God had willed, we would not have given associates, nor would have our fathers, and we would not have forbidden anything [against His will]'” (Q. 6:148). Whoever argues for stripping away the command and prohibition with determination is one of these. This has become frequent among those Sufis who claim [to have attained] reality.

The third sect is the Iblisis who acknowledged the two elements, but they regarded them as contradictory in the Lord-Glory be to Him, Exalted is $\mathrm{He}$ - and they discredited His wise purpose ( hikma) and His justice (' $\mathrm{C} d l$ ), just as this is mentioned concerning Iblīs, their ringleader, according to what the experts in sectarian teachings (ahl al-maqälät) transmitted and what is transmitted from the People of the Book.

The point is that [the above] is what the people who go astray say. As for the People of Guidance and Success, they believe in both. They believe that God is Creator, Lord and Sovereign of everything. What He wills is, and what $\mathrm{He}$ does not will is not. He is powerful over everything, and His knowledge encompasses everything.... And it is necessary to believe in legislation. This is belief in the command and the prohibition and the promise and the threat, as God raised up His messengers with this and sent down His books. ${ }^{4}$

As noted under the fourth position, that of the People of Guidance and Success, Ibn Taymiyya includes "the promise and the threat" on the side of divine command and prohibition..$^{5}$ This involves the promise of reward for good deeds and the threat of punishment for bad deeds. Under command, he elsewhere includes "the names and the judgments (al-asmä wa al-abkām)" which deal with whether one is a believer or unbeliever. ${ }^{6}$ These matters fall on the side of command rather than creation because they involve questions of human accountability.

In other texts, Ibn Taymiyya identifies all of the first three positions cited above as Qadarī. This yields the "Majūsī Qadarīs," the "Mushrikī Qadarīs” and

\footnotetext{
4 Tadmuriyya, MF 3:111-3. Much of the ellipsis is translated below (157-8).

5 The connection between command and prohibition, or related notions, and promise and threat also occurs in Jabr, MF 8:452; and Shams, MF 16:230, 235.

6 Furqān, MF 13:211.
} 
the "Iblīsī Qadarīs." These are polemical labels rather than names of actual groups. The sense of Qadari in these appellations is that of anyone who goes astray on the doctrine of determination (qadar), and the adjectives Majūsī, Mushrikī and Iblīsì denote three different ways of erring. Ibn Taymiyya occasionally uses other adjectival forms with Qadarī such as "Mujbirī Qadarīs," "Jabrī Qadarīs" and "Murjì̄ Qadarīs." ${ }^{10}$ For Ibn Taymiyya the Mujbirīs or Jabrīs deny that humans are the agents of their acts, and the Murjiīis, who did constitute an actual movement in early Islamic history, understand faith (iman) as assent and knowledge without deeds. ${ }^{11}$ The shaykh places both groups under the category of Mushriki Qadarīs because of their perceived weakness in upholding human accountability.

\section{Qadarìs and Mütazilīs: Compromising Creation}

The terms Mushrikī Qadarī and Iblīsī Qadarī do not appear often in Ibn Taymiyya's writings. ${ }^{12} \mathrm{He}$ most commonly reserves the term Qadari for those who follow the precedent of the historical Qadari trend in early Islam and deny that God creates human acts. ${ }^{13}$ He states, for example, "Not one of the Qadarīs affirms that God is Creator of the acts of servants." ${ }^{14}$ Ibn Taymiyya also calls Qadarīs "Deniers (nufäh)" because they deny that God can make someone either obedient or disobedient. ${ }^{15}$ In light of this, the shaykh often uses the term Qadarī to denote the Mu'tazilīs. ${ }^{16} \mathrm{He}$ cites the Mu'tazilī Abū al-Husayn al-Bașrī as a prominent proponent of the Qadarī view and credits

\footnotetext{
${ }^{7}$ For these three types of Qadarīs, see Fì Fusūus, MF 2:409-411; Qadariyya, MF 8:256261; MF 10:718; and Shams, MF 16:230, 232, 235, 238, 239.

${ }^{8}$ Furqän, MF 13:212, 225; and Hasana, MF 14:247. In Iräda, MF 8:105, Ibn Taymiyya also notes that some early scholars in Islam called those who believed in God's compulsion ( jabr) of human acts Qadarīs.

9 Nubuwwāt, 96.

${ }^{10}$ Iräda, MF 8:105.

${ }^{11}$ For Ibn Taymiyya's views on the Jabrīs, see below. For his views on the Murji'īs, see Imän I, MF 7:190ff., and the translation of this work, Kitab Al-Iman: Book of Faith, trans. Salman Hassan Al-Ani and Shadia Ahmad Tel (Bloomington, IN: Iman Publishing House, 1999), 200ff. See also Shams, MF 16:241-3.

12 I located five occurrences of the term "Iblīsī Qadarīs" in MF: Fì Fusūụ, MF 2:400, 411; Qadariyya, MF 8:260; MF 10:718; and Shams, MF 16:232.

${ }_{13}$ On the Qadarī movement in early Islam, see W. Montgomery Watt, The Formative Period of Islamic Thought (Edinburgh: Edinburgh University Press, 1973), 82-118.

${ }_{14}$ Shams, MF 16:232. Cf. Fì Fusūs, MF 2:400, where Ibn Taymiyya includes with the Qadarīs the "naturalists" who attribute acts to bodies, natures, celestial spheres or souls rather than God.

${ }_{15}$ Furqān, MF 13:225-6. Cf. Hasana, MF 14:347.

16 See for example Shams, MF 16:239; and Minhäj, 3:18/2:267.
} 
him with being "the foremost of the later Mu'tazilis." ${ }^{17} \mathrm{He}$ also uses the term Qadarī for later Shî̀i such as Ibn al-Muțahhar al-Hillī who adopt Mu'tazilī theology. ${ }^{18}$ In creation and command typologies, Ibn Taymiyya typically only explains that the Mu'taziliss reject God's creation of human acts in order to maintain His justice, but he does give the Mu'tazilī rationale closer attention in other contexts.

The term Majūsī, which appears in the quotation from Tadmuriyya above, comes from Majūs, the Arabic word denoting the followers of the dualist, Persian religion Zoroastrianism, also called Mazdaism. ${ }^{19}$ The Majūs were known to Ibn Taymiyya as believing in an agent of evil other than God. He adds that they were a community which paid the jizya to the Muslims and whose women some scholars said Muslims could marry. ${ }^{20} \mathrm{He}$ equates the Majūs with the Persians, ${ }^{21}$ and he explains that they fell into dualism (thanawiyya) by inquiring into the cause of evil. ${ }^{22}$ The shaykh links the Qadarīs to the Majūs on the basis of a hadith in which the Prophet is said to have called the Qadarīs "the Majūs of this community." ${ }^{23} \mathrm{He}$ also notes

17 Shams, MF 16:236. Concerning Abū al-Husayn, Ibn Taymiyya continues, "He had more intelligence and erudition than most of his peers, but he had little acquaintance with the traditions (al-sunan), the meanings of the Qur'an and the path of the Salaf."

${ }^{18}$ For example, see Minhäj, 3:181/2:34, where Shīis are subsumed under the Qadarīs, and Minhāj, 3:190/2:37, where Ibn Taymiyya calls his opponent al-Hillī a Qadarī. Minhājj, 1:127-8/1:31, describes how later Shî'is adopted Mu'tazilī doctrine. For the assimilation of the Mu'tazilīs to the Qadarīs in early Kalām theology, see Daniel Gimaret, La doctrine d'alAsh' arī (Paris: Cerf, 1990), 396-8.

19 On Zoroastrianism and its relationship to the Islamic tradition, see M. Morony, "Madjūs," EI2 5:1110-8; Guy Monnot, Penseurs musulmans et religions iraniennes: 'Abd al-Jabbār et ses devanciers (Paris: Librairie philosophique J. Vrin, 1974), 77-81, 88-91, 137-142; Guy Monnot, Islam et religions (Paris: Éditions Maisonneuve et Larose, 1986), 129-156 (on alMāturīdī) and 157-170 (on the Ash'arī al-Bāqillānī); and Christoph J. Bürgel, "Zoroastrianism as Viewed in Medieval Islamic Sources," in Muslim Perceptions of Other Religions: A Historical Survey, ed. Jacques Waardenburg (Oxford, UK: Oxford University Press, 1999), 202-212. For the view that Zoroastrianism and Mazdaism are synonymous, see Gherardo Gnoli, "Zoroastrianism," in The Encyclopedia of Religion, ed., Mircea Eliade (New York: MacMillian, 1987), 15:579-591. On the dualism of both Zoroastrianism and Manichaeism in relation to Islam, see G. Monnot, "Thanawiyya," EI2 10:439-441. Also of interest on Islamic responses to dualism is G. Vajda, "Le Témoignage d'al-Māturidī sur la doctrine des Manichéens, des Dayșānites et des Marcionites," Arabica 13 (1966): 1-38, 113-128.

${ }^{20}$ Iräda, MF 8:100.

${ }^{21}$ Shams, MF 16:239.

${ }^{22}$ Ta'iyya, MF 8:248 (reading 'illat al-sharr instead of 'illat al-sirr).

${ }^{23}$ Wäsitíyya, MF 3:150; Abū Dāwūd. 4071, Al-Sunna, Fĩ al-qadar. Sarah Stroumsa and Gedaliahu G. Stroumsa, "Aspects of Anti-Manichaean Polemics in Late Antiquity and under Early Islam," Harvard Theological Review 81:1 (1988): 37-58 (especially 54-5), cite this hadith as evidence that debate over divine determination in Islam emerged in the context of the challenge posed by Zoroastrian, as well as Manichaean, dualism. 
that the Qadarīs resemble the Majūs inasmuch as both "affirm [someone] other than God who produces evil things apart from His will, His power and His creation. ${ }^{24}$ The point in comparing the Qadarīs to the Majūs is to accuse the former of a dualism of creators when they posit human beings as the creators of their acts.

The quotation from Tadmuriyya above also distinguishes between "extremist" Majūsīs who deny God's foreknowledge and "moderate" Mu'tazilīs who do not. In Jabr Ibn Taymiyya reports that Ma'bad al-Juhanī (d. 83/703) promulgated the extremist Qadarī teaching first in Basra to counter the Umayyads but was opposed by the Companions of the Prophet. ${ }^{25}$ Elsewhere, the shaykh notes that deniers of foreknowledge argue that it would be bad of a prince to command someone to do something when he knows that the person will not obey, and so also with God. ${ }^{26}$ Apart from such occasional mentions, denial of God's foreknowledge is not a major concern for Ibn Taymiyya, and he says that almost no one denied it in his time. ${ }^{27}$

\section{Sufi Antinomians, Jahmis, Jabris and Ash' aris: Compromising Command}

Turning now to the Mushrikī Qadarīs, or more simply the Mushrikīs, the crux of the problem shifts from denying God's creation of human acts to nullifying God's command. The term mushrik means idolater or more literally one who associates partners (ashraka) with God, and, for Ibn Taymiyya, Mushrikī is a term of aspersion rather than the name of a historical group. The shaykh's primary concern in the Tadmuriyya quotation above is the argument of the Arab associationists found in the Qur'an that divine determination prevented them from pure worship of God. He notes that this argument is widespread among Sufi gnostics in his time. He alleges that the Sufi antinomians (mubäbiyya) are worse than the Arab associationists. The latter, he observes, at least have some laws whereas the Sufis annul the Law completely. ${ }^{28}$

$24 \mathrm{Jabr}, \mathrm{MF} 8: 452$.

${ }_{25} \mathrm{Jabr}$, MF 8:450. Cf. Sa'äda, MF 8:288. According to Watt, Formative Period, 85, 87, Ma'bad was involved in political opposition to the Umayyads and denied that God had determined their misdeeds. J. van Ess underlines the politically charged and thus uncertain nature of the sources for knowledge of this figure in "Ma'bad b. 'Abd Allāh b. 'Ukaym alDjuhanī, EI2 5:935-6.

26 Shams, MF 16:233.

${ }^{27}$ Wäsitiyya, MF 3:148-9. God's foreknowledge is discussed briefly in Tahsin al-'aql, MF 8:429-430; and Shams, MF 16:233-4. A full defense consisting mostly of quranic quotations occurs in Jabr, MF 8:490-7.

${ }^{28} \mathrm{Jabr}, \mathrm{MF} 8: 457-8$. 
Ibn Taymiyya writes prolifically against this "determination argument (alihtijajj bi-l-qadar)." ${ }^{29}$ His main complaint is that it does not hold up against human rationality. Reason and the natural constitution know it to be a vain argument. ${ }^{30} \mathrm{He}$ explains that no one will accept divine determination as an excuse for injustice, violation of his wife, and murder of his son. Nor will anyone who excuses his own misdeeds with determination accept it as an excuse from someone who acts against him. Everyone is subject to the same divine determination, and so it cannot serve as an argument for anyone. The shaykh asserts that, if all could do as they pleased without censure, the world would be destroyed. ${ }^{31}$

On this basis, Ibn Taymiyya adopts a pragmatic perspective. If someone is warned of an approaching enemy, he does not wait for God to create "fleeing" in him; he strives to flee and then God helps him flee. ${ }^{32}$ Someone who truly wills to believe and obey God and has the power to do so will do it. If he does not do it, it is because he did not will it. ${ }^{33}$ Whoever defends his sins with determination is simply following his caprice and does not have knowledge. ${ }^{34}$ For Ibn Taymiyya, the proper attitude is patience with the afflictions that God has determined. In sins the response should be repentance and asking forgiveness, while in acts of obedience one should also confess God's determination to avoid pride. ${ }^{35}$

The shaykh identifies two different foundations of Sufi antinomianism, one particular and the other general. ${ }^{36}$ The particular occurs when the individual Sufi in ecstatic annihilation ( $\operatorname{fan} \vec{a}$ ) erroneously believes that he no longer has a will of his own but passes away into the will of the Real. In this witnessing (mushähada), any distinction between good and evil does not apply to the gnostic, and the Law is no longer relevant. Ibn Taymiyya cites the Hanbalī Sufi Abū Ismāēil al-Anșāīi al-Harawī (d. 481/1089) as an example of this line of thinking. In response Ibn Taymiyya appeals to the teaching of the early Sufi master al-Junayd (d. 298/910) that even in witnessing the

${ }^{29}$ Giving extended attention to the qadar argument are Ibtijāj, MF 8:303-370; Minhäj, 3:54-86/2:2-11; Qad̄à, MF 8:262-271; 'Ubüdiyya, MF 10:157-172; and Ibțāl, MF 2:300-3, 323-330.

${ }^{30}$ Minhäj, 3:56/2:3, 3:60/2:4, and 3:65/2:5.

${ }_{31} T_{a}^{-} a$, MF 8:263; Tä̀iyya, MF 8:248-251; Jabr, MF 8:453-5; Minhāj, 3:56-7/2:3; 'Ubüdiyya, MF 10:164-5; Ibțäl, MF 2:300-2; and Iräda, MF 8:114.

${ }^{32}$ Minhāj, 3:67/2:5. Cf. Minhāj, 3:65/2:5.

${ }_{33}$ Minhāj, 3:69-70/2:6.

${ }^{34}$ Minhäj, 3:65/2:5; and 'Ubüdiyya, MF 10:165.

35 Iḅtijäj, MF 8:327-8, 331; Minhäj, 3:78/2:8; 'Ubūdiyya, MF 10:159-160; Ibțāl, MF 2:301-2; Tadmuriyya, MF 3:122; MF 8:76-7; and MF 8:237.

${ }^{36}$ Fi Fușus, MF 2:364-370, outlines the two perspectives. 
universal will of God one must also witness command and prohibition. ${ }^{37}$ He also asserts that 'Abd al-Qādir al-Jilānī (d. 561/1166), the eponym of the Qãdirī Sufi order, prohibits arguing from determination. ${ }^{38}$ Ultimately, the shaykh asserts, the Sufi gnostic cannot escape the fact that he still draws distinctions between what profits and harms him, and this is in fact what the Law was sent to clarify. ${ }^{39}$

Ibn Taymiyya identifies a general basis for antinomianism in the doctrine of Ibn 'Arabi and his followers whom the shaykh calls the "People of the Oneness of Existence (abl wahdat al-wujüd)" (ittihädiss)." ${ }^{\prime 1}$ The shaykh interprets their teaching as a monism that collapses a proper distinction between God and His creatures and makes God identical to creation. This leads to the repulsive notion that God punishes Himself and is identical to idols, satans, pigs and unbelievers. ${ }^{42}$ Ibn Taymiyya alleges that Ibn 'Arabī and his followers thus accept any kind of worship: "They agree with every form of associationism in the world, equate God with every created thing, and permit worship of everything." ${ }^{43}$ Furthermore, the shaykh charges the Unificationist poet al-Tilimsānī (d. 690/1291) with falling into explicit antinomianism, making all forbidden things lawful, even marriage to one's mother or daughter. ${ }^{44}$

Although Ibn Taymiyya does not mention the Jahmīs, Jabrīs and Ash' arīs in the above typology from Tadmuriyya, he includes them in similar discussions elsewhere. He accuses them of upholding determination at the expense of God's command, and he sometimes links them to Sufi antinomianism. ${ }^{45}$ He usually takes the early Muslim theologian Jahm b. Șafwān to be the source of this tendency, explaining that Jahm upheld God's determination

\footnotetext{
${ }^{37}$ Hasana, MF 14:354-5. Cf. Ihtijājj, MF 8:317-8, 346, 369; Awliyä, MF 11:245; Minhäj, 3:168/2:31; and Furüq, MF 8:228-9.

38 Ihtijāj, MF 8:306, 369. Ibn Taymiyya devotes the treatise 'Abd al-Qaddir, MF 10:455-548, to 'Abd al-Qādir's Futūḥ al-ghayb. The latter has been translated as 'Abdul-Qādir al-Jīlānī, Revelations of the Unseen (Futūh al-Ghaib), trans. Muhtar Holland (Houston, TX: Al-Baz, 1992).

39 Tadmuriyya, MF 3:116-7; and Ihtijäj, MF 8:308-311, 346-7.

${ }^{40}$ Fì Fusūus, MF 2:367. Cf. Ibtäl, MF 2:294ff.

${ }^{41}$ Ittihädiyyìn, MF 2:134, 140-1.

42 Ittiḩädiyyīn, MF 2:142, 173; Fì Fușūs, MF 2:364-5; and Ibțäl, MF 2:331, 355-6.

${ }^{43}$ Ittih̄ädiyyin, MF 2:255.

${ }_{44}$ Manbijì , MF 2:472; and Fì Fușūs, MF 2:364-7. Ibn Taymiyya, Ibțāl, MF 2:342, also reports that al-Tilimsānī said that even a dead, scabby dog was part of God's essence.

${ }_{45} T_{a}^{-r} a$, MF 8:444-5; I $\underline{b} t i j a ̈ j$, MF 8:352-3; and Hasana, MF 14:346-359. Cf. Shams, MF 16:235.
} 
in the extreme. ${ }^{46} \mathrm{Ibn}$ Taymiyya describes Jahm and his followers the Jahmis as Jabrīs and Mujbirīs, calling Jahm himself "the Imām of the Mujbirīs." ${ }^{47}$ Additionally, the shaykh frequently compounds the names Jahmī and Mujbirī to yield "Mujbirī Jahmīis." ${ }^{48}$ The labels Jabrī and Mujbirī both derive from the word jabr (compulsion), which denotes the idea that God, as the sole Actor in the universe, compels the human act. In earlier Islamic history, these terms did not denote a particular group but were used by the Mu'tazilis to cast aspersion upon their opponents. ${ }^{49}$ Ibn Taymiyya asserts that the Jahmis were the first to deny that humans were truly the agents $\left(f_{\bar{a}} \bar{i} i l\right)$ of their acts, and he reports that it was said that they believed that "the servant is compelled (majburr), and he has no act fundamentally." ${ }^{\text {o }}$ The shaykh accuses Jahm of several related errors. Jahm sees no real difference between good and evil deeds. ${ }^{51}$ He rejects God's wise purpose, justice and mercy by denying that God creates and commands for a cause or reason: "[Jahm] used to deny that God was the Most Merciful of the merciful. He used to go out to the lepers, look at them and say, 'The Most Merciful of the merciful has done the likes of this with them."'52 Ibn Taymiyya also claims that Jahm and his followers bear a strong resemblance to the people of India (abl al-Hind), but he does not explain why. ${ }^{53}$ The Muslims knew the Brahmans (Baräbima) of India primarily as deniers of prophecy, and possibly Ibn Taymiyya linked an extreme emphasis on compulsion to a denial of the need for prophecy.

Under the rubric of the Jabrīs, Ibn Taymiyya mentions the Ash'arī theologian Fakhr al-Dīn al-Rāzī. ${ }^{54} \mathrm{He}$ writes, "[Al-Rāzī] openly proclaimed that he taught jabr," ${ }^{55}$ and he calls al-Rāzī a "pure Jabrî." 56 As we will see in the next chapter, al-Rāzì does in fact call himself a Jabrī, and the well-known

46 Hasana, MF 14:346-358, in which passage Ibn Taymiyya accuses Jahm of two innovations: denial of the divine attributes and excess in divine determination. The Mu'tazilis then fell into the first error and the Ash'arīs the second. Cf. Ihtijäj, MF 8:347, 352ff. In Fì Fușūs, MF 2:367, Ibn Taymiyya says that the Ittihādīs realized the Jahmī position better than anyone else.

${ }^{47}$ Kasb, MF 8:394; and Minhäj, 3:75/2:7. In Thulth, MF 17:177, Ibn Taymiyya calls Jahm "the Imām of the extremist Mujbirīs."

${ }_{48} \mathrm{Jabr}$, MF 8:497; Minhāj, 3:75/2:7, 3:193-6/2:38; and Hasana, MF 14:310.

49 Watt, Formative Period, 118.

${ }^{50} \mathrm{Jabr}$, MF 8:460.

51 Jabr, MF 8:466; and Hasana, MF 14:346-358.

$52 \mathrm{Jabr}$, MF 8:460. This story is also found in Nubuwwāt, 353; Minhäj, 3:32/1:270; and Thulth, MF 17:102.

53 Shams, MF 16:239.

54 Shams, MF 16:236; and Istițā'a, MF 8:375.

${ }_{55}$ Minhāj, 3:267/2:56.

56 Ibtijajj, MF 8:307. 
Ash ${ }^{\text {ari }}$ doctrine of acquisition (kasb) in human acts is of no consequence to either al-Rāzī or Ibn Taymiyya. Beyond this, Ibn Taymiyya is convinced that al-Rāzî̀s doctrine of $j a b r$ annuls ethical distinctions: "[Al-Rāzī] firmly believes...that the servant is compelled (majbür) [to do] his act and that the act of one compelled is not bad. Thus, no acts of servants are bad." ${ }^{57} \mathrm{Ibn}$ Taymiyya believes that al-Ash' arī is better in this regard since he affirms that the difference between command and prohibition is real for creatures even if not for God..$^{58}$

It is something of an oddity that the two major groups that Ibn Taymiyya brings together under the one rubric of those compromising command-the Sufis and the Ash'arīs-differ fundamentally in their approach to problems of evil. The Sufis typically adopt some kind of optimism while the voluntarism of the Ash'aris completely rejects rationality in God's will. What the two groups share, however, is belief in God's determination of all existents, and Ibn Taymiyya's primary concern in this type is with those who shirk God's command because they take determinism to be incompatible with human responsibility.

\section{Free-thinkers and Poets: Impugning God's Wise Purpose and Justice}

The Iblīisis constitute the third group in the Tadmuriyya typology quoted earlier. Ibn Taymiyya explains that the Iblisisis take their name from their forerunner Iblīs and accuse God of injustice and foolishness in what He creates and commands. Elsewhere, Ibn Taymiyya identifies this as the view of "the fools among the poets and such like among the free-thinkers (zanädiqa)," and he cites the poet Abū al-'Alä' al-Ma'arrī (d. 449/1058) as an example. ${ }^{59}$ Curiously, Ibn Taymiyya does not identify the voluntarist Jahmīs and Ash'arīs explicitly with the Iblīsi position even though their problems are similar: both deny rationality in God's all-determining will. Possibly the difference is that the shaykh regards the Ash'arīs as seeking to maintain a semblance

57 Shams, MF 16:246.

58 Hasana, MF 14:355; and Shams, MF 16:246-7.

59 Qadariyya, MF 8:260. I have not found Ibn Taymiyya naming any particular free-thinkers on the question of God's justice. One of the better known is Ibn al-Rāwandī (4th/10th century) who voiced the basic Iblīsi complaints mentioned here in a book called Kitäb al-tá dìl wa al-tajwìr. For notice of this book, see Abū al-Husayn 'Abd al-Raḥmān b. Muhammad b. 'Uthmān al-Khayyāț, Kitäb al-intișār, ed. H.S. Nyberg and trans. Albert N. Nader (Beirut: Les lettres orientales, 1957), 12 (trans. 2); and Sarah Stroumsa, Freethinkers in Medieval Islam: Ibn al-Rāwandī, Abü Bakr al-Rāzì, and Their Impact on Islamic Thought (Leiden: Brill, 1999), 131-2, which includes an English translation of al-Khayyāț's notice. 
of piety in practice while the Iblīsī position is that of explicit skepticism, disbelief and rebellion.

The Qur'an does not speak of Iblis's denial of God's wisdom and justice. It only mentions that he grew proud and refused to bow before Adam at God's command. ${ }^{60}$ However, as noted in the typology from Tadmuriyya above, Ibn Taymiyya indicates that experts in sectarian teachings and the People of the Book have transmitted an account of Iblīs's defamation of God's wisdom and justice. ${ }^{61}$ He probably has in mind the story of Iblis's seven objections to God's wisdom found at the beginning of the Kitäb almilal wa al-niḥal of al-Shahrastānī. (Among other charges, Iblīs questions God's wisdom in creating him when God already knew what would become of him). ${ }^{62}$ A passage in Iräda similar to that in Tadmuriyya makes explicit reference to al-Shahrastānī's account and the fact that al-Shahrastānī traces it to the People of the Book. Ibn Taymiyya casts doubt on the authenticity of the story by noting that it lacks a proper chain of transmission, and he goes on to argue that it is probably a Mu'tazili forgery. ${ }^{63}$

In Iräda the shaykh also explains why the Mu'tazilis would have interest in forging such a story: "Their intention in this is to refute those who affirm determination. They say that God's case against His creatures can only be brought forward by denying determination." ${ }^{64}$ In Ibn Taymiyya's view, the

${ }^{60}$ The story of Iblīs is found in Q. 2:34, 7:11-8, 15:28-42, 17:61-5, 18:50, 20:116-120 and 38:71-85. On the reception of this story in Sufism, see Peter J. Awn, Satan's Tragedy and Redemption: Iblìs in Sufi Psychology (Leiden: E.J. Brill, 1983).

${ }^{61}$ Tadmuriyya, MF 3:111. In Minhāj, 3:82/2:9, Ibn Taymiyya also mentions that a disputation by Iblis was related, but he does not indicate by whom.

${ }^{62}$ Muhammad b. 'Abd al-Karīm al-Shahrastānī, Al-Milal wa al-nihal, ed. Ahmad Fahmī Muhammad (Beirut: Dar al-kutub al-ilmiyya, n.d.), 7-9, which is translated in Muhammad b. 'Abd al-Karīm al-Shahrastānī, Muslim Sects and Divisions: The Section on Muslim Sects in Kitāb al-Milal wa 'l-Niḩal, trans. A.K. Kazi and J.G. Flynn (London: Kegan Paul, 1984), 12-5, and Shahrastani, Livres des religions et des sectes, trans. Daniel Gimaret and Guy Monnot (Louvain: Peeters, 1986), 1:115-9.

${ }^{63}$ Iräda, MF 8:114-5. Sarah Stroumsa, Freethinkers, 130-1, sees the ethical challenge presented to monotheists by Manichaean and Zoroastrian dualists behind this story. Stroumsa and Stroumsa, "Aspects of Anti-Manichaean Polemics," 51-8, argue that Mu'tazilīs such as 'Abd al-Jabbār sought to refute the dualist challenge by rejecting the foolish and unjust God of the Manichaean caricature of monotheism. This Mu'tazili polemic then found a target closer home in their Mujbirī co-religionists whose belief in God's absolute determination seemed to bear a strong resemblance to the Manichaean caricature. These observations do not, of course, prove that al-Shahrastānīs story of Iblīs was a Mu'tazilī forgery, but they do indicate the sort of milieu in which it may have arisen. The above comments may also help to explain why, in Fì Fusūss, MF 2:400, Ibn Taymiyya lists the Majūsīs not with those who deny God's creation of human acts but with the Iblisisis. Perhaps he was thinking of the Zoroastrian polemic against the goodness of a monotheistic God.

${ }^{64}$ Irāda, MF 8:115. 


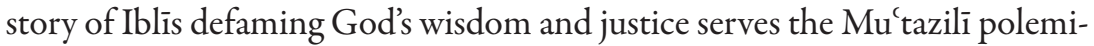
cal purpose of undermining belief in God's all-encompassing creation and determination. If God's creation of all human acts can be shown to entail foolish and unjust behavior from God, then this view must be wrong. This is in fact the strategy adopted by the Shîî scholar al-Hillīin in Minhäj alkarama, the Mu'tazili-inspired polemic against Sunnism that Ibn Taymiyya in turn refutes in Minhāj. Al-Hillì’s basic charges against an all-determining God have already been noted in the description of Minhäj found in the Introduction to this study.

In setting out the four-fold typology of positions on creation and command, Ibn Taymiyya does not always highlight Iblīsī skepticism. Instead, one version confronts ethical laxity with a quotation attributed to the Hanbali scholar Ibn al-Jawzī, "You are a Qadarī in obedience, and you are a Jabrī in disobedience, which is to say, whatever school of thought suits your caprice is the one you adopt." ${ }^{65}$ Ibn Taymiyya says that people holding this view take credit for their good deeds but blame their acts of disobedience on God's decree, and he notes that this is not a particular school of thought but the attitude of those unconcerned with the Law. In other places dealing with creation and command, the shaykh cites this statement in conjunction with Sufi antinomianism. ${ }^{66}$

To sum up the creation and command typology, Ibn Taymiyya charges that the Sufis and the Ash'aris emphasize God's determination at the expense of God's command and drift towards a monism that collapses the human sphere entirely into God. He castigates the Mu'tazilīs for dualism in denying that God creates human acts, and he censures those who impiously reject God's creation and command on the grounds that they are irrational and unjust. Ibn Taymiyya himself maintains the reality of both the human responsibility involved in God's command and the all-encompassing character of God's creation without favoring one at the expense of the other. He makes no effort here to resolve the conundrum of creation and command rationally. He simply wards off theological and ethical shortcomings that he perceives in the solutions of others.

${ }^{65} T_{a ̂ a}^{a} a$, MF 8:446.

${ }^{66} \mathrm{Ibtaal}$, MF 2:301; and Shams, MF 16:248. The quotation is also found in MF 8:241; 'Ubüdiyya, MF 10:165; and Abü Dharr, MF 18:204. 


\section{Ibn Taymiyya: Analogy Is the Cause of Error in Creation and Command}

Ibn Taymiyya's commentary on Surat al-Shams (Q. 91) [hereafter Shams] ${ }^{67}$ provides a colorful analysis of the causes of the three types of error in creation and command noted above. The shaykh here traces the roots of the problem to a common Qadarī and Jabrī presupposition in the realm of ethical value and to an analogy Iblīs drew from himself to God. These same points are made elsewhere, but Shams appears to be unique in the degree to which it draws them together and fills them out into a story of what went wrong.

Ibn Taymiyya opens Shams with a brief comment on the sura's first eight verses. ${ }^{68}$ Then he devotes the bulk of his energy to polemic involving the eighth verse, "[God] inspired [the soul] to its immorality ( fujür) and its piety (taqwa)" (Q. 91:8). This one verse, he claims, exposes error in both the Majūsī Qadarī and the Jabrī/Mushrikī/Sufi antinomian currents of thought. Ibn Taymiyya explains that inspiration (ilhäm) here carries the meaning of creation. Thus, God is Creator of both piety and immorality. This invalidates a Qadari interpretation of inspiration that excludes God's creation of human acts even if it affirms both God's foreknowledge and God's determination of everything else. ${ }^{69}$

The shaykh then contends that the verse also establishes God's legislation because the phrase "its immorality and its piety" distinguishes between the good of piety that is commanded and the evil of immorality that is prohibited. If the verse had read only, "He inspired it to its acts," the indication of command and prohibition would not have been present. "There would be no distinction between the good and the evil, the loved and the hated, and the commanded and the prohibited." As it stands, however, the verse "is a proof against the Mushrikīs, such as the antinomians and Jabrīs, who do away with command and prohibition, and good and bad." ${ }^{\prime 0}$

Thus the verse, "He inspired [the soul] to its immorality and its piety," affirms both God's creation and God's command. Ibn Taymiyya also finds both together in other verses such as "He misguides whomever He wills, and He guides whomever He wills” (Q. 16:93). In this verse, God's will involves

67 Shams, MF 16:226-250. The text gives no indication of its date. At MF 16:237, Ibn Taymiyya mentions having once elaborated something elsewhere but without specifying the location.

68 Shams, MF 16:226-30.

69 Shams, MF 16:230-4.

70 Shams, MF 16:235. 
creation of all things, while guidance and misguidance involve the distinction between good and evil found in His command and prohibition. ${ }^{71}$

Following a discussion of the human act in Shams, Ibn Taymiyya locates the ultimate source of Qadarī and Jabrī difficulties in the shared presupposition that rational judgment of ethical value is incompatible with God's creation of human acts. He argues that both the Qadarīs and the Jabrīs agree that something created by God cannot be subject to judgments of moral value by virtue of some inherent quality. "They say, 'If [God] is the Creator of an act, it is impossible for the act to be inherently good and deserving of reward or bad and deserving of punishment."'72 The Jabrīs then conclude that acts cannot be inherently good or bad since God creates everything. Good and bad only arise from the command and prohibition of the God who has the right to "command what He wills without any quality [inhering] in it and prohibit what He wills without respect to any quality [inhering] in it." ${ }^{33}$ On the other hand, the Qadarīs conclude that God does not create human acts because acts are indeed inherently good or bad. If God created inherently bad acts, He Himself would be bad. ${ }^{74}$

In Shams Ibn Taymiyya does not defend himself against what appears to be the inevitable conclusion of his polemic: that God creates inherently bad acts. Instead, he continues his diatribe against the Qadaris and the Jabrīs, showing his preference for the Qadarīs and the Mu'taziliss over the Jabrīs because the former give stronger emphasis to God's command and prohibition. Following this, the shaykh turns to the Iblisiss. He explains that they acknowledge God's command as well as His determination. They err, however, in claiming that, in the contradiction of these two, God is ignorant and foolish and that God is unjust to punish someone for what He created in him. ${ }^{75}$ Ibn Taymiyya then traces the source of Iblīs's error to the analogy he drew from himself to God in his rebellion:

[Iblis] said, "Because You misled me, I will indeed adorn the path of error for them in the earth, and I will mislead them all" (Q. 15:39). He confessed that God misled him. Then he deemed that to be a motive making it necessary for him to mislead Adam's progeny. Iblis was the first to show enmity toward

${ }^{71}$ Shams, MF 16:235.

2 Shams, MF 16:237-8.

3 Shams, MF 16:238.

74 Shams, MF 16:238. Similarly, in 'Ubüdiyya, MF 10:166, Ibn Taymiyya indicates that neither Sufi antinomians nor the Mu'tazilīs can imagine someone being commanded to do the opposite of what has been determined for him.

75 Shams, MF 16:238-9. 
God, exceed the proper bounds of His creation and command, and oppose what was appointed with analogy (qiyās).

Because of this, one of the Salaf said, "The first to draw an analogy was Iblīs." God commanded him to prostrate before Adam, but he opposed that command with, "I am better than him" (Q. 7:12), and he refused to prostrate. He was the first to show enmity toward God. He is ignorant and unjust-ignorant of the wise purpose in the command of God and unjust by virtue of his pride in which he combined disregard for the Real (al-Haqq) and contempt for humanity.

Then his statement to his Lord, "Because You misled me, I will surely do [such and such]," made God's act-which is His misleading him-into his argument and motive for misleading humankind. This was his discrediting of God's act and His command and his allegation that it was bad. So [he said], "I will do bad also." He drew an analogy from himself to his Lord and likened himself to his Lord. Thus, he was imitating [God] in lordship. ${ }^{76}$

In this passage, Iblīs's first error is to draw an analogy between himself and Adam and then to conclude that God's command was without wise purpose. Moreover, Iblīs accuses God of having committed a bad act in misleading him. This is also based on an analogical projection of his own sense of good and bad onto God, which, in Ibn Taymiyya's judgment, is tantamount to claiming the prerogative of lordship.

In Shams the shaykh does not directly accuse the Qadarīs/Mu'tazilīs of holding God analogically to human standards of good and bad, but it is implicit in his analysis of why they maintain that God cannot create bad acts. If we say that God cannot do acts that we know to be inherently bad, then we are holding God to human standards of what is bad. As we will see later in Chapter Six, Ibn Taymiyya argues this explicitly against the $\mathrm{Mu}^{\prime}$ tazilis in his discussions of God's justice. In discussing God's creation and command, the shaykh also does not accuse the Jabrīs/Ash'arīs of falling into the analogy trap. Yet, this as well is implicit in his analysis here in Shams when he argues that the Jabrīs share with the Qadaris the common presupposition that God could not create inherently bad deeds. Thus, the Jabrī viewpoint also rests on a human analogical judgment about what is impossible for God. This common presupposition of the Qadarīs and the Jabrīs comes out clearly in Ibn Taymiyyas narrative description of their joint failure to defeat Iblis:

The Qadarīs intended to exonerate God of foolishness. Their intention was good because $\mathrm{He}$-Glory be to Him-is much too holy for what the unjust among Iblis and his forces say. [He is] a wise arbiter and just. However, [the Qadarīs] were not up to the task, and a sort of ignorance overtook them. With

\footnotetext{
${ }^{76}$ Shams, MF 16:239-240.
} 
this, they firmly believed that this exoneration could only be completed by stripping Him of His power over the acts of servants, His creation of them, and His all-encompassing will of everything. They disputed with Iblis and his party in one thing, but Iblīs got the better of them from another angle. This is one of the greatest banes of debating in religion without knowledge or without truth. This is the talk (kalam) that the Salaf blamed. One who does this refutes vanity with vanity and innovation with innovation.

Then groups from the People of Affirmation [of determination] came and disputed with [the Qadarīs] in order to establish firmly that God is Creator of everything, that what God wills is and what He does not will is not and that $\mathrm{He}$ is powerful over everything. However, their strength and knowledge were not up to the task. For they firmly believed that this could not be completed unless we deny God's love, good pleasure and the good and evil attributes that set one act apart from another and we deny His wise purpose and His mercy. Thus, every act is admissible for $\mathrm{Him}$, and $\mathrm{He}$ is exonerated neither from injustice nor any other act. ${ }^{77}$

Here Ibn Taymiyya alleges that the Qadarīs maintain God's wisdom and justice at the expense of God's power, creation and will. The "People of Affirmation" (i.e. Jabrīs) maintain God's creation, will and power against the Qadarīs at the expense of God's love and good pleasure and His wise purpose, justice and mercy. In the Jabrī outlook, God can do anything, and good and evil are totally subjective.

It must be said, of course, that the historical figures lying behind the polemical labels Qadarī and Jabrī do not deny the divine attributes in question. Rather, they interpret them in senses not to Ibn Taymiyya's liking. Yet, this raises questions about the coherence of the shaykh's polemic in Shams. On the one hand, he rejects analogical extension of human concepts onto God. On the other, he has definite ideas about what God's attributes mean-obviously based on some kind of relation to human language-and he criticizes those who differ with his interpretations. However, the shaykh does not explain in Shams how he himself escapes the analogy trap, and his polemic taken in isolation presents itself as completely contradictory. Sense can be made of it only by reference to his theological methodology surveyed in Chapter One. The God who bears no analogy to creatures must nonetheless be spoken well of - given the highest similitude-in accord with considerations of tradition and reason.

77 Shams, MF 16:241. 


\section{Modes of Expressing Creation and Command in Ibn Taymiyya's Thought}

\section{Creation and Command in the Wāsitiyya Creed}

The previous two sections have outlined Ibn Taymiyyas polemic against those whom he believes fail to uphold creation and command in proper balance. The commentary in Shams has shown also how the shaykh reads creation and command into the quranic term inspiration (ilhäm) and the contrast between piety and immorality, respectively. The present section examines the diverse modes of expression that fall under this rubric more directly, beginning with the basic confession of creation and command found in the segment on God's determination in Ibn Taymiyya's well-known catechismal creed $W_{a}$ sitityya. ${ }^{78}$ The shaykh opens this segment by affirming that the People of the Sunna believe in "determination, the good of it and the evil of it." He then proceeds to note that belief in determination has two stages. The first stage (daraja) is belief in God's knowledge of all human acts from eternity and in God's writing down all that He determined to be, in general and in detail. The second stage of belief in determination sets out God's creation and command:

As for the second stage, it is the operational will of God (mashì at Alläh alnäfidha) and His all-inclusive power (qudra). It is belief that what God wills is and that what He does not will is not. And that there is no motion and rest in the heavens and the earth except by the will of God-Glory be to Him. There is nothing in His sovereignty except what He wills. And that He-Glory be to Him, and Exalted is $\mathrm{He}$-is powerful over everything among existents and nonexistents. There is no created thing in the earth or in heaven but that God is its Creator-Glory be to Him. There is no creator other than Him and no lord except Him.

Along with this, He has commanded His servants to obey Him and obey His messengers, and He has prohibited them from disobeying Him. He-Glory be to Him-loves the pious, the beneficent and the fair, and He is well pleased with those who believe and perform righteous deeds. He does not love the unbelievers, and $\mathrm{He}$ is not well pleased with iniquitous people. He does not

78 "Al-'Aqīda al-wāsițiyya," MF 3:129-159, which is equivalent to MRK 1:387-406 and has been translated into three European languages: Henri Laoust, La profession; Merlin Swartz, "A seventh-century (A.H.) Sunnī creed: The 'Aqīda Wāsițiya of Ibn Taymīya," Humaniora Islamica 1 (1973): 91-131; and Clemens Wein, trans., Die Islamische Glaubenslehre ('Aqida) des Ibn Taimiya (Bonn: n.p., 1973). This creed became very well known in Ibn Taymiyyas day and has had widespread appeal down to the present. For affirmations similar to those found here in Wäsitiyya, see MF 8:235-8; Täi iyya, MF 8:246-7; and Jabr, MF 8:449-450, 452, 459, 466. 
command abomination, and He is not well pleased with unbelief in His servants. He does not love corruption.

Servants are agents in reality (haqiqatan), and God is the Creator of their acts. The servant is the believer and the unbeliever, the righteous and the immoral, the one praying and the one fasting. His servants have power to do their acts, and they have a will. God is their Creator and the Creator of their power and their will, as $\mathrm{He}$-Exalted is $\mathrm{He}$ - said, "To whosoever among you wills to go straight. You will not unless God, Lord of the worlds, so wills" (Q. 81:28-9).

The vast majority of the Qadarīs denounce this level of determination as lies-those whom the Prophet-God bless him and give him peace-called the Majūs of this community. A group from among the people who establish [God's attributes and determination] are extreme in it to the point that they strip the servant of his power and choice, and they exclude wise purposes (hikam $)^{79}$ and benefits from God's acts and judgments. ${ }^{80}$

The first paragraph of this passage establishes that God's attributes of will, power, sovereignty, lordship and creation encompass everything. He is the Creator of all things. The third paragraph treats the special instance of God's creation of human acts. Ibn Taymiyya is here concerned to maintain that human acts are real and that humans are in fact the agents of their acts despite God's will and creation of them. The human act will receive further consideration in Chapter Four. The second paragraph links God's command to His attributes of love (mababba) and good pleasure (rid̄a $)$. God loves and is well pleased with belief and obedience, and He does not love unbelief, disobedience and corruption. The fourth paragraph disparages the Qadari position on determination and criticizes those who deny that God acts for wise purposes and benefits (i.e. the Jabrīs).

\section{Lordship and Divinity}

Parallel to the creation/command distinction in Ibn Taymiyya's thought is a further distinction between God's lordship and divinity. We have already met these two notions in Chapter One, and, as noted there, God's lordship (rubübiyya) deals with His creation of all things and the great need of creatures to call upon Him for help while God's divinity (ulübiyya or ilähiyya) is linked to His command and indicates His essential right to worship. These

79 Laoust, La profession, 73, appears to have read hikam as hukm because he renders the Arabic as "sens" ("sense" or "meaning"). The plural form bikam of the singular bikma ("wisdom" or "wise purpose") flows better with the Arabic style of the sentence since it lies in parallel with the clearly plural mașalih ("benefits").

${ }^{80}$ Wäsitizya, MF 3:149-150; the translation is my own. 
terms usually appear in strongly ethical discussions, often dealing with the verse in the Fātiha, "You alone we worship; You alone we ask for help" (Q. 1:5). These discussions make an appeal to confess both that God is the only Lord who may be called upon for help (tawhid al-rubübiyya or al-tawhìd al-rabbānī) and that God is the sole divinity or worthy object of worship (tawhìd al-ulühiyya or al-tawhìd al-ilähì). This tawhid al-ulühiyya excludes any kind of shirk or giving partners to God; God has the right to exclusive devotion. ${ }^{81}$

A reasonably full treatment of these concepts appears in Ibn Taymiyya's $F \bar{\imath}$ Fusūus, an apologetic text directed toward Sufis. Its primary lacuna is explicit reference to the Avicennan causal analysis relating lordship as the efficient cause to divinity as the final cause, which was noted in Chapter One. In discussing lordship, Ibn Taymiyya affirms that God is the Lord, Creator and Sovereign of all things. He created the heavens and the earth. The heart of every servant is "between two fingers of the fingers of the All-Merciful. If $\mathrm{He}$ wills to set them aright, He sets them aright. If $\mathrm{He}$ wills to turn them aside, He turns them aside." $\$ 2$ The Lord makes people laugh, and He makes people cry. He sends the wind and the rain. He guides and misguides. $\mathrm{He}$ knows all things and has power over them. ${ }^{83}$ The shaykh complements God's overwhelming power, lordship and governance with His goodness, wise purpose and mercy. Everything that God has created is good, perfect and wise. His mercy extends far and wide, and, as found in the Hadith, "Indeed, God is more merciful toward His servants than this mother toward her son." ${ }^{\prime 4}$

Ibn Taymiyya draws these affirmations together under two principles: 1 ) the universality of God's creation and lordship and 2) the universality of His beneficence (ihsān) and wise purpose. God's attributes of lordship and sovereignty are not capricious but give evidence of God's goodness and mercy. God creates all, and all that God creates is good and wise. All things are in fact signs of God, and they manifest (muzhir) the names and attributes of God from which they derive. ${ }^{85}$

Following this Ibn Taymiyya moves in Fì Fusūus to God's divinity (ilāhiyya), which indicates that creatures should make God their god (ta'alluh), that is,

${ }^{81}$ Tawhid, MF 1:22-3; Shirk, MF 1:89-90; Manbijī, MF 2:455-9; Tadmuriyya, MF 3:98-109; 'Ubüdiyya, MF 10:156-8; Fätiha, MF 14:5-15, 31-6; Hasana, MF 14:376-380; Mahabba, 24-5; Talbis, 2:454; and Minhäj, 3:276-336/2:59-74.

${ }^{8 \dot{2}}$ Fì Fușus, MF 2:398-9.

${ }^{83}$ Fì Fușūs, MF 2:398-9.

${ }^{84}$ Fì Fusūus, MF 2:399-400. This hadith is found in Bukhārī, 5540, Al-Adab, Rahmat alwalad wa taqbīluhu wa mu'ānaqatuhu; Muslim 4947; and Ibn Māja, 4287.

${ }^{85}$ Fì Fușuss, MF 2:400. 
their object of worship, and that worship should be devoted to God alone. ${ }^{86}$ The shaykh elaborates further that the source of God's exclusive right to worship is God's essence or very self (nafs):

To Him is the destiny [of beings] and their return, and He is their object of worship and their God. It is not fitting that any [being] be worshipped except Him-just as no one created them but $\mathrm{He}$ - because of that to which He has a right in Himself (limä buwa mustabiqqubu bi-nafsibi) and of that which $\mathrm{He}$ alone possesses of the attributes of divinity, in which He has no associate. ${ }^{87}$

Ibn Taymiyya then discusses how God's divinity and lordship appear in humans. Traces of divinity and the rulings of the law are manifest only in those who serve God, take God as a friend, agree with God in what He loves and is well pleased with and follow what He commands and prohibits. God manifests traces of His lordship and the rulings of His power in both believers and unbelievers as He gives them provision, property, beauty, knowledge and religious experiences. The manifestation of lordship apart from divinity is especially clear in Pharaoh, the Mongol conqueror Ghengis Khan and the one-eyed Dajjāl. The manifestation of divinity and lordship together occurs in angels, prophets and friends of God as in the Prophet Muhammad and the Messiah, son of Mary. Ibn Taymiyya notes further that lordship corresponds to the judgments of the 'ontological words' and divinity to judgments of the 'religious words', and he gives an extensive list of such 'words. ${ }^{88}$ These two kinds of words correspond to creation and command, respectively, and they will be examined next from a different text.

\section{Ontology and Legislation}

Ibn Taymiyya often qualifies matters linked to God's determination and creation with the term ontological (kawni) and things related to God's command and prohibition with the terms religious ( $\operatorname{din} \bar{i})$ and legislative $\left(\operatorname{shar}^{\mathrm{r}} \overline{\mathrm{i}}\right)$. The shaykh speaks, for example, of the "ontological, determinative and lordly realities (al-ḥaqü iq al-kawniyya al-qadariyya al-rubübiyya)," which apply to all things, and the "religious, legislative, divine realities (al-haqä iq al-diniyya al-shar iyya al-ilähiyya)," which extend only to those who obey God's command. ${ }^{89}$ Other similar ways of speaking include God's "address of generation

\footnotetext{
${ }^{86}$ Fì Fusūs, MF 2:404-6.

${ }^{87}$ Fì Fuṣūs, MF 2:406.

${ }^{8}$ Fì Fușūs, MF 2:407-8, 411-3.

89 Fätiḅa, MF 14:15; and 'Ubüdiyya, MF 10:156-7.
} 
(khițāb al-takwin)" and God's "address of obligation (khițāb al-taklîf),",90 and "His ontological creation (khalqubu al-kawnī)" and "His religious command (amrubu al-dini).".'11 Ibn Taymiyya takes a number of quranic terms to have an ontological meaning in some contexts and a legislative meaning in others. Among these are God's will (iräda), decree (qadä), judgment ( authorization $(i d h n)$ and command $(a m r)$. The shaykh sets these out in list form with example quranic verses and hadiths in a number of texts. ${ }^{92}$

One such list, which is typical of the rest, is translated below with its introduction. This passage falls within Taraddud, a short fatwa on the meaning of God's hesitation (taraddud) found in the Hadith of Supererogatory Works (badith al-nawäfl). The last portion of the hadith reads, "I do not hesitate over anything as I hesitate over taking the soul of My believing servant. He hates death, and I hate to torment him." ${ }^{93}$ Ibn Taymiyya notes that God loves His servants who draw close to Him through supererogatory works, and so He hates to take their lives. Yet, God has decreed death. God's hesitation means that God decrees death despite the fact that He hates it. There is thus a conflict of interest between God's love and God's decree. To resolve this, Ibn Taymiyya concludes that God has a wise purpose ( ikma) in everything that He determines and decrees. ${ }^{94}$ In the middle of the fatwa, Ibn Taymiyya notes that a similar conflict between God's moral attributes and His ontological attributes exists in His willing of unbelief and disobedience, and this leads him into a listing of parallel ontological and religious terms:

[Concerning] the unbelief, iniquity and disobedience that occur in existence. God-Exalted is $\mathrm{He}-$ loathes that, displays wrath against it, hates it and prohibits it. And $\mathrm{He}-$ Glory be to Him-has determined it, decreed it and willed it with His ontological will (al-iräda al-kawniyya), even if He did not will it with a religious will (iräda diniyya). This is the crux of the matter ( fașl al-kbitāab) about which the people dispute: Does He-Glory be to Him-command what He does not will?

\footnotetext{
${ }_{90}$ Marātib, MF 8:182-6.

${ }^{1}$ Fì Fusūus, MF 2:409.

92 The fullest text of this kind that I have located is Awliy $\vec{a}$, MF 11:265-271, which is translated in Yahya M. Michot, "Textes Spirituels d'Ibn Taymiyya: II. L'étre (kawn) et la religion (dîn)," Le Musulman (Paris) 13 (1990-1): 7-10, 28. Similar lists are found in Fī Fusüus, MF 2:411-3; Tuhfa, MF 10:23-8; and MF 8:58-61.

${ }_{93}$ This is the last part of the hadìth al-nawäfl found in Bukhārī, 6021, Kitāb al-riqāq, Bāb al-tawāḍu'. See Graham, Divine Word and Prophetic Word, 173-4, for a brief discussion of the transmission and content of this hadith.

${ }_{94}$ Taraddud, MF 18:129-135, which is translated into French in Yahya Michot, Un Dieu hésitant? (Beirut: Dar Al-Bouraq, 1425/2005).
} 
The general belief among the Kalām theologians who establish [determination] and those who agree with them from among the jurists is that He commands what He does not will. The Qadarīs, the Mu'tazilīs and others say that He only commands what He wills.

The truth of the matter is that will (iräda) in the Book of God is of two kinds: a religious, legislative will and an ontological, determinative (qadari $)$ will. The first is like His statement-Exalted is He-"God wills ease for you. He does not will difficulty for you" (Q. 2:185), and His statement-Exalted is $\mathrm{He}$ - "He wills to purify you" (Q. 5:6). And His statement-Exalted is $\mathrm{He}-$ "God wills to make plain to you and to guide you in the ways of those before you," to His statement, "and God wills to turn toward you" (Q. 4:26-7). Here, will has the meaning of love and good pleasure, and this is the religious will. The indicator of this is His statement, "I did not create the jinn and humankind except that they might worship Me" (Q. 51:56).

As for the ontological, determinative will, this is like His statement-Exalted is He- "Whomever God wills to guide, He opens his breast to Islam. Whomever He wills to misguide, He makes his breast narrow and tight as if he were climbing up to the sky" (Q. 6:125). And like the saying of the Muslims, "What God wills is, and what God does not will is not." All beings are encompassed in this will (iräda) and necessitating will $(i s h \vec{a} a)$. Good and evil, right and wrong do not deviate from it. This will and the necessitating will include what the legislative command does not include. The religious will corresponds to the legislative command. They do not differ. This division between the ontological, determinative and the religious, legislative appearing in the term will appears likewise in the terms command (amr), words (kalimät), judgment (bukm), decree (qada $\vec{a})$, writing (kitäb), raising up (ba th), sending (irsāl) and their like.

The ontological words are those from which neither a righteous person nor an immoral person deviates. These are those with which the Prophet-God bless him and give him peace — asked for help in his statement, "I take refuge in the complete words of God that no righteous or immoral person oversteps." 95 God-Exalted is $\mathrm{He}$-said, "His command when He wills something is only that He says to it, 'Be!' and it is" (Q. 36:82). As for the religious [words], these are the books sent down about which the Prophet said, "Whoever fights so that the word of God is exalted is on the path of God." "And He-Exalted is He-said, "She judged the words of her Lord and His books to be true" (Q. 66:12).

Also, the religious command is like His statement-Exalted is $\mathrm{He}$ - "Truly, God commands you to deliver trusts back to their owners" (Q. 4:58). And the ontological, "His command when He wills something" (Q. 36:82). ${ }^{97}$

95 Ahmad, 14914, Musnad al-makkiyyīn, Hadīth 'Abd al-Rahmān b. Khanbash.

${ }^{6}$ Bukkhārī, 120, Al-'Ilm, Man sa’ala wa huwa qāàm 'āliman jālisan; Bukhārī, 2599; Muslim, 3525; and elsewhere.

${ }_{97}$ Ibn Taymiyya only quotes the first part of this verse, having already quoted it in full above. 
The religious raising up is like His statement-Exalted is $\mathrm{He}$ - "It is $\mathrm{He}$ who raised up from among the unlearned a Messenger from among them" (Q. 62:2). And the ontological raising up, "We raised up against you servants of ours" (Q. 17:5). The religious sending is like his statement, "He it is who sent His messenger with guidance and the religion of truth" (Q. 9:33). And the ontological, "Do you not see that We sent satans against the unbelievers to incite them" (Q. 19:83)..$^{98}$

Behind some of these terms lie polemical debates and distinctions. The first part of the quotation mentions the difficulties of Kalām theologians with will, and these will be treated below. ${ }^{99}$ A further example comes from Ibn Taymiyya's polemic against Ibn 'Arabîs's interpretation of decree ( $q a d \vec{a} \overrightarrow{)})$. In the verse, "Your Lord has decreed that you serve none but Him" (Q. 17:23), Ibn 'Arabī understands decree ( $q a d \vec{a})$ to mean that no one in the universe worships anyone but God, no matter what his immediate object of worship might be. In the story of Aaron, Moses and the calf, for example, Ibn 'Arabī says that Moses knew that those worshipping the calf were in fact worshipping God because this is what God decreed. ${ }^{100}$ In Ibn Taymiyya's view, Ibn 'Arabi incorrectly reads decree in Q. 17:23 in an ontological sense, while the context of the verse dictates that decree means command. ${ }^{101}$

\section{Ontological Will and Legislative Will}

Several times in his writings, Ibn Taymiyya sets out the two types of will (iräda) found in the list from Taraddud above along with the same or similar illustrative verses. ${ }^{102}$ The two types receive a number of different names. For example, the shaykh calls them the "commanding will (al-iräda al-amriyya)" and the "creative will (al-iräda al-khalqiyya)." ${ }^{103}$ On the side of creation are also "the ontological, determinative (qadariyya) will" ${ }^{104}$ and "the ontological,

98 Taraddud, MF 18:131-3.

99 See also discussion of the two types of command (amr) in Ibtäl, MF 2:289, 320-330, and the two types of authorization (idhn) in Hasana, MF 14:383ff., which occur in a treatment of God's authorization of intercession in Q. 2:255. Cf. Qawl 'Ali, MF 8:168.

100 See Muhyī al-Dīn Ibn 'Arabī, Fusūus al-hikam, ed. and commentary Abū al-'Alä' 'Afîfī (Beirut: Dār al-kitāb al-'arabī, n.d.), 72 and 191-2. Both passages from Füṣuṣ al-bikam are quoted by Ibn Taymiyya in Ittiḩädiyyin, MF 2:251-2.

101 Ittibādiyyin, MF 2:264.

102 Minhäj, 3:16-7/1:266-7, 3:156-7/2:29, 5:412-3/3:103; Iräda, MF 8:131, 140; MF 8:159; MF 8:197-8; MF 8:201-2; Täa, MF 8:440-1; Jabr, MF 8:476; and Thulth, 17:62-63.

${ }_{103}$ Minhāj, 5:413/3:103.

${ }^{104}$ Minhäj, 3:156/2:29. 
all-inclusive (shämila) will." ${ }^{105}$ Other ways of drawing the distinction include "the will of decree (qadä) and determination (taqdirr)" versus "the will of command and legislation (tashrî ),"106 and "the will of generation (takwin)" versus "the will of command, Law, love, good pleasure and religion." ${ }^{107}$ The following passage speaks of the two wills in yet another combination of terms-determinative, creative and commanding, legislative-and links them to lordship and divinity, respectively. Also, God's commanding will is linked to God's love and good pleasure and that which is beneficial for human beings.

The Salaf, the leaders of the jurists and the great majority of Muslims affirm creation and command: the determinative, creative will including every originating event and the commanding, legislative will concerning everything that God loves and is well pleased with for His servants, which is what the Messengers were commanded and is what profits servants, is beneficial to them, and has a praiseworthy end, profitable at the Return $\left(a l-m a^{\prime} \bar{a} d\right)$ and repelling corruption. This commanding, legislative will is linked to His divinity which includes His lordship. Similarly, that creative, determinative will is linked to His lordship. ${ }^{108}$

Ibn Taymiyya outlines the four possible combinations of ontological will and legislative will in a brief treatise called Maràtib al-iräda. First, the two wills coexist in the generation of righteous deeds. Second, righteous deeds that do not occur are linked to the legislative will, but not to the ontological. Third, acts of disobedience and permitted acts (mubāhăt) that occur, but are not commanded, are linked to the ontological will, but not the legislative. Fourth, neither the legislative will nor the ontological will are linked to permitted acts and acts of disobedience that do not occur. ${ }^{109}$ Ibn Taymiyya makes similar notes on the combinations of the two wills elsewhere. For example, he defines the happy person as the one in whom God's will of determination and will of command concur and the unhappy person as the one in whom they do not. ${ }^{110}$ Also, God wills belief and obedience from those

105 Irāda, MF 8:131.

106 MF 8:197.

107 MF 8:201-2.

108 Thulth, MF 17:64.

109 Marātib al-irāda, MF 8:188-9, which is translated in Fritz Meier, "The Cleanest about Presdestination: A Bit of Ibn Taymiyya," in Essays on Islamic Piety and Mysticism, trans. John O'Kane (Leiden: Brill, 1999), 309-334 (text on 328-9), which is in turn a translation of Fritz Meier, “Das sauberste über die vorbestimmung: Ein stück Ibn Taymiyya," Saeculum 32 (1981): 74-89. Reference to Meier hereafter is only to the English. Bell, Love Theory, 67, provides a diagram illustrating the various combinations of will.

110 MF 8:198. 
who believe and obey both in command and creation, and He helps them and makes them do that. On the other hand, God commands unbelievers to believe and obey in His legislative, religious will, but He does not will to create their obedience in His ontological will. This is for a wise purpose and a benefit that overrides whatever benefit may have been attained in creating obedience. ${ }^{111}$

The shaykh furthermore links the ontological will to God's mashì a (will) and, as we saw above, the legislative will to His love and good pleasure. ${ }^{112}$ For Ibn Taymiyya, the semantic fields of mashi $\vec{a}$ and $i r \bar{a} d a$ are not identical, and this presents a problem in translation. For lack of better alternatives, I usually translate both terms as "will" and transliterate the Arabic when necessary. Ibn Taymiyya uses mashi $\vec{a}$ only for God's ontological activity as when he says that the irada "linked to the creation is the mash $\vec{i} a$ and is the ontological, determinative iräda." ${ }^{113}$ The term iräda, however, carries either an ontological or a legislative sense depending on the context. ${ }^{114}$

The distinction between iräda and mash $\vec{\imath} a$ also becomes apparent in Ibn Taymiyya's discussion of oath taking. If someone swears an oath that he will do such and such if God wills $(s h \vec{a} a)$ and does not do it even when he has no excuse, he has not broken his oath. A person cannot be held accountable for not conforming to God's mash $\vec{i} a$. If, however, he swears an oath by God's love, and he does not do it, then he has broken his oath. He is liable to do what God loves and commands. If he swears by God's iräda and does not do it, he has broken his oath only if he intended the iräda of love. ${ }^{115}$

Ibn Taymiyyas primary polemical targets when discussing the two types of irāda are Kalām theologians who make the semantic fields of divine will, love and good pleasure identical. This has different results for the $\mathrm{Mu}^{\text {'tazilis }}$ and the Ash'arīs, respectively. The shaykh reports that the Mu'tazilīs equate love, good pleasure and will-both iräda and mash $\vec{i} a$-solely with God's command. In this case, things exist which God does not will ( yash $\vec{a})$, and God wills things that do not exist. ${ }^{116}$ Ibn Taymiyya reports that al-Juwayni

${ }_{111}$ Minhäj, 5:414. Cf. Minhāj, 3:162-3 and 182-3, and MF 8:199.

112 Minhāj, 3:233/2:47-8; and MF 8:159.

113 Minhāj, 3:156/2:29.

${ }^{114}$ Bell's brief discussion of mash $\vec{i} a$ and iräda in Love Theory, 65-6, is not sufficiently precise and may be read to mean that both $\operatorname{mash} \vec{\imath} a$ and $i r a \bar{d} a$ carry ontological and religious senses. As noted here, however, Ibn Taymiyya uses mashb $\vec{i} a$ only in the ontological sense.

${ }_{115}$ Minhāj, 3:16/1:266, 3:19/1:267, 3:155-6/2:28, 3:188/2:36; and Jabr, MF 8:475. Cf. Minhāj, 3:258/2:54.

${ }_{116}$ Minhäj, 3:14-5/1:266, 3:158/2:29, 3:196/2:39; Iḥtijäj, MF 8:340; and Jabr, MF $8: 474,476-7$. 
said that al-Ash'arī was the first to equate divine love, good pleasure and will (both iräda and mashi $\vec{i}$ ) wholly with God's creation of all that exists, and in this he was followed by Abū Yà lā, al-Juwaynī himself and others. The shaykh says that this ultimately goes back to Jahm b. Șafwan, although he also accuses the latter of denying God's attributes completely. ${ }^{117}$ In this Ash'ari view, God loves and is well pleased with everything, including iniquity, unbelief and disobedience. God loves, wills and is well pleased with all that exists. He does not love and will what does not exist, and $\mathrm{He}$ is not well pleased with it. Ibn Taymiyya notes that the Ash'aris reinterpret such verses as "God does not love corruption" (Q. 2:205) and "God is not well pleased with unbelief in His servants" (Q. 39:7) to mean that God does not love and will corruption and unbelief in those in whom they do not exist or that God does not love and will these things religiously in the sense that He does not will to reward the corrupt and the unbeliever. ${ }^{118}$

Ibn Taymiyya also reports that al-Ash'arī held a second position, which is that of the majority among those who believe in only one type of iräda. In this view, the iräda is God's mashì a alone whereas God's love and good pleasure are linked to His command. ${ }^{119}$ The shaykh attributes this view to most of the Kalām theologians, the Karrāmīs and the Hanbalīs Abū Bakr 'Abd al-'Azìz and Ibn al-Jawzī. ${ }^{20}$ Ibn Taymiyya argues that the majority of Sunnīs up to the time of al-Ash 'arī, as well as subsequently, distinguish God's iräda of all things from His love and good pleasure linked to His command. However, it is not always clear whether the shaykh also attributes a two-iräda view to this majority or simply a separation between a single irada on the one hand and love and good pleasure on the other. ${ }^{121}$

For the sake of independent historical perspective, Gimaret and Bell have shown that the complete identification of love and good pleasure with all that God wills to exist is not found in Ash'arī theology until al-Juwaynī. It also appears that no Ash ${ }^{\mathrm{C}}$ ari followed him in this thereafter. ${ }^{122}$ Bell cites the

117 Minhäj, 3:15/1:266, 5:412/3:102-3; Jabr, MF 8:475; Hasana, MF 14:353; and Thulth, MF 17:101-2.

${ }_{118}$ Minhäj, 3:14-5/1:266, 3:158-9/2:29, 3:196/2:39-40; Ibtijāj, MF 8:340-5; Jabr, MF 8:476-7; Thulth, MF 17:101; and Iräda, MF 8:98. Much of Iräda, MF 8:97-106, is translated in Rahman, Revival and Reform in Islam, 149-153.

${ }_{119}$ Minhäj, 3:181/2:34.

${ }_{120}$ Minhäj, 5:411-2/3:102-3.

${ }_{121}$ Minhāj, 3:15/1:266, 3:17-8/1:267, 3:159/2:29; and Jabr, MF 8:475-6.

122 Bell, Love Theory, 56-60. See al-Juwaynī, Kitāb al-irshād, 99 (in the middle of "Bāb al-qawl fì al-istițā'a wa hukmihā"), for the identification of will, love and good pleasure. In this text, however, al-Juwaynī does not identify this view as that of al-Ash'arī explicitly but only as that of those Ash'arīs who are right (man haqqaqa min a'immatinā). D. Gimaret, 
later Ash'arīs al-Ghazālī and al-Rāzì as maintaining a distinction between good pleasure and love on the one hand and will on the other. ${ }^{123}$ Also, Roger Arnaldez has shown that al-Rāzì sets out a scheme of two wills, one pertaining to creation and one to command. ${ }^{124}$ Additionally, the Sufi Abū Țälib al-Makkī (d. 386/996) identifies iräda with mashï $a$ and love with God's command, and he also then distinguishes two types of iräda: one pertaining to generation and one to command. ${ }^{125}$ In sum Ibn Taymiyya says nothing new with his doctrine of two wills and the restriction of love and good pleasure to God's legislative will. However, he singles out al-Juwaynī's view that God loves all that exists and makes it a frequent focus of polemic. He may believe that this is what Ash'arism truly reduces to, or possibly this doctrine enables him to make the link that he perceives to exist between Ash'arī theology and antinomian Sufism. ${ }^{126}$

\section{Ibn Taymiyya Defending the Coherence of Creation and Command}

As is clear from the preceding discussion, Ibn Taymiyya devotes much effort to holding creation and command in balance without compromising one to the other and without succumbing to skepticism or irrationality. However, he devotes relatively little energy to exploring the sense of their relationship when they appear to contradict. Yet, he does not ignore the problem completely. Perhaps his most powerful metaphor capturing the paradoxical

"Un problème de théologie musulmane: Dieu veut-il les actes mauvais? Thèses et arguments," Studia Islamica 40 (1974): 5-73 and 41(1975): 63-92 (at 40:17-23), locates the direct attribution of this view to al-Ash'arī only in non-Ash'arī texts including the Māturīdī theologian al-Pazdawī (d. 593/1099), and he adds that he could find no grounds in al-Ash'ari’s texts for attributing the view to the master himself.

123 Bell, Love Theory, 233 n. 5. For further historical background, see especially Gimaret, "Un problème de théologie musulmane," 40:17-23; and al-Julaynad, Qadiyyat al-khayr wa al-sharr, 42-51 (includes Mu'tazilī views). See also, Gardet, Dieu et la destinée de l'homme, 120-1; and Meier, "The Cleanest about Predestination," 321-2.

${ }_{124}$ Roger Arnaldez, "Apories sur la prédestination et le libre arbitre dans le commentaire de Razi," Mélanges de l'institut dominicain d'études orientales 6 (1959-1961): 123-136 (at 135-6).

${ }^{125}$ Abū Țālib al-Makkī, $Q \bar{u} t$ al-qulüb (n.pl.: n.p., n.d.), 1:127-8 (i.e. toward the end of Section 30 in Vol. 1), distinguishes between God's command which attaches only to religious obligations and God's love which attaches to both religious obligations and supererogatory works. See also the general discussion of the conflict between God's will (iräda) and command (amr) in Sufism in Awn, Satan's Tragedy and Redemption, 101-9.

126 Ibn Taymiyya clearly links the Ash 'arī equation of will and love to Sufi antinomianism in Ihtijajj, MF 8:337-370; and Hasana, MF 14:346-359. Cf. Bell, Love Theory, 90-1. 
linkage of creation and command is the image of seeing with two eyes. I have found only one clear usage of this in the shaykh's writings. Concerning God's will of determination and God's will of the Law, he says, "Judgment $(a l-h u k m)$ goes according to these two wills. Whoever looks at deeds with these two eyes sees. Whoever looks at determination without the Law or the Law without determination is one-eyed." 127

Ibn Taymiyya explores the coherence of his position in a few different places, but it is in Minhāj, writing against al-Hillī the Shīi theologian of Mu' tazilī orientation, that he makes his fullest contribution. Al-Hillì strongly insinuates that the will of the Sunni God is irrational, charging inter alia that the Prophet disobeys God in commanding belief when the Sunni God wills the unbelief of the unbeliever. ${ }^{128} \mathrm{Ibn}$ Taymiyya's counter polemic against Mu'tazilism has been surveyed above. Here we focus on the shaykh's attempt to defend the rationality of his approach.

\section{Wise Purpose in Commanding but not Helping}

In an extended discussion in Minhāj, Ibn Taymiyya distinguishes two kinds of will (iräda) as follows. First is the will of an agent to perform his own act, and second is the will of an agent that someone else commit an act. ${ }^{129} \mathrm{~W}$ ith respect to God, the shaykh observes that some affirm only the first kind of will, God's will to act Himself. These are obviously the Jabrīs, although he provides no labels. Conversely, the Qadaris affirm the second kind of will but deny the first by denying that God creates human acts. Ibn Taymiyya asserts that the Salaf affirm both kinds of will, and he continues with examples from human affairs of how this might be so to advance the plausibility of this view. For instance, someone may command another to do what profits the latter but not help him do it because there is no benefit (maslaba) in it for the commander. This is like someone who advises another to marry a certain woman but does not marry her himself. Ibn Taymiyya argues that if

${ }^{127}$ MF 8:198. When discussing God's lordship and divinity in Shirk, MF 1:90, Ibn Taymiyya speaks similarly, but less vividly, of two views (mashhad): "When the servant is found true in this view [of lordship] and [God] gives him success in that such that this view does not veil him from the first view [of God's divinity], he is learned (faqih) in his servitude. These two views are indeed the pivot around which the religion turns." For this reference I am indebted to Yahya M. Michot, "Textes Spirituels d'Ibn Taymiyya: IV. Entre la divinité et la seigneurialité, le polymorphisme de l'associationnism (shirk)," Le Musulman (Paris) 16 (1991): 8-13, (at 10), which translates Shirk, MF 1: 88-94.

${ }_{128}$ Minhāj, 3:154/2:28.

129 Minhäj, 3:168-177/2:31-4. This distinction is also made in Minhäj, 3:18/1:267; and Jabr, MF 8:477-8. 
this distinction is possible with respect to creatures it is a fortiori possible with respect to God. God has commanded human beings what profits them and prohibited them from what harms them. Yet, God does not create all acts which He commands. Such was the case in God commanding Pharaoh and Abū Lahab to believe but not helping them do so because of His wise purpose in that or to avoid some unspecified detriment (mafsada).

Ibn Taymiyya goes on in Minhäj to emphasize that commanding someone to do something that will benefit the commanded or even the commander is not the same as helping the commanded carry out the act. The commander may refrain from helping in order to avoid his own detriment. As an example, the shaykh cites the quranic story of one who came running to warn Moses to flee. "He told Moses, 'A crowd is conspiring to kill you. Leave! I am an advisor to you' (Q. 28:20). It was to his benefit to command Moses to leave but not to help him in that. Indeed, if he had helped him, his people would have harmed him." ${ }^{130}$ Again, Ibn Taymiyya argues that if it is possible on the human plane that someone command but not help out of consideration for his own wise purpose and benefit then it is a fortiori possible for God. He adds another example to illustrate the basic concept. Someone-apparently a king, although the shaykh does not specify — may realize that it would be to the benefit of one of his subjects to learn the ways of power. Furthermore, this king might command his subject to do what would benefit him (i.e. the subject). However, the king himself will not help his subject lest he rise up as an enemy against the king's son. The upshot is that God has a wise purpose in all that He commands and all that He creates "even if there is a kind of harm in that for some people on account of the wise purpose in that." 131

Ibn Taymiyya's various illustrations from human affairs presuppose libertarian freedom in the one commanded, that is, freedom to act apart from any external control. Yet, as the shaykh makes clear at the beginning of this passage in Minhäj, the distinction between willing to act oneself and willing that another act involves subsuming the creation of human acts strictly under God's own will to act. It thus goes without saying that Ibn Taymiyya's examples do not apply to the God-human relationship univocally, and the shaykh acknowledges this in an aside as he reiterates his main point:

[As for] the examples that are mentioned concerning creatures-even if it is not possible to mention the like of them with respect to God-the point here is that it is possible with respect to the wise creature to command someone else

130 Minhāj, 3:172/2:32.

131 Minhāj, 3:171-5/2:32-3 (quote at 3:175/2:33). 
with a command and not help him do it. The Creator is all the more worthy $(a w l \bar{a})$ of that possibility with respect to Him with His wise purpose. ${ }^{132}$

As elsewhere, Ibn Taymiyya does not explain the methodology of his theological jurisprudence as well as he might, but reference to the quranic injunction to give God the highest similitude (al-mathal al-a'lā) discussed in Chapter One makes his procedure reasonably clear. While maintaining that God's essence, attributes, and acts are wholly unlike those of creatures, the shaykh nonetheless seeks to ascribe to God praiseworthy human perfections. In the present passage from Minhäj, Ibn Taymiyya wards off the implication in al-Hilli's polemic that the relationship between creation and command is irrational by building on examples of human wisdom to point to the praiseworthiness of God's wisdom.

Ibn Taymiyya continues in Minhäjj with some suggestions as to God's wise purposes in untoward things. God's creation of illness and oppression lead to invocation, humility, repentance, expiation of sins, removal of pride and enmity, and softening of the heart, all benefits that health and justice would not necessarily bring. Ibn Taymiyya ends the present Minhajj discussion of two wills by saying that it is not given to humans to know the details of God's wise purposes. ${ }^{133}$ Further attention will be given to God's wise purposes in evil in Chapter Five below.

A little later in Minhāj, Ibn Taymiyya again draws a distinction between will as commanding another and will as helping another. The shaykh quotes the Shîi theologian al-Hillì's charge that someone (i.e. the Sunnī God) who commands what he does not will and wills what he prohibits is foolish. Ibn Taymiyya argues that this is not so. A doctor who commands a sick person to take medicine does not have to help his patient take it, and advisors in matters of business and agriculture do not have to follow their own advice. Conversely, an advisor may tell an advisee not to do what the advisor himself is doing because it would be harmful to the advisee. The shaykh notes that a snake handler is not foolish to prohibit his son from handling a snake. Likewise, a swimmer tells someone who cannot swim not to swim, and a king who goes out to fight prohibits women from going out with him. Upon mentioning these examples, Ibn Taymiyya makes a clear statement of his methodological aim. He notes that it is not possible to find an example or similitude that is applicable to God in every respect since there is nothing like Him. Rather, the point is to show that it is possible that one

132 Minhāj, 3:176/2:33.

133 Minhāj, 3:176-7/2:33. 
commands what he does not will, whereas the Mu'tazilis think this to be foolish necessarily. ${ }^{134}$

\section{Doing what one Hates for a Wise Purpose that Is Loved}

As Bell has observed, Ibn Taymiyya also tries to give sense to the conundrum of creation and command by interpreting God's creation of things contradicting His command as a means to that which He loves. Again, the shaykh articulates this most fully in Minhäj when responding to al-Hillī’s Mu'tazilism. He argues that humans may will things that they hate as when taking medicine. Conversely, they may will not to have things that they love as when a sick person does not eat something that would harm him. Similar logic applies to someone fasting who does not eat even though he loves food or does not drink even though he is thirsty. Likewise for someone who loves to follow his appetites but does not do so because he hates them from the perspective of his reason and religion. The shaykh infers that if these distinctions are possible with respect to creatures, then there is no reason that they might not be possible for God. Ibn Taymiyya extends this thinking into a distinction between what is willed and loved in itself and what is willed accidentally as a means (wasila) to something that is loved in itself. For example, a sick person may take medicine as a means to the health that he loves and wills. Thus, the shaykh concludes, there are two kinds of will (irāda): the will for what is loved in itself and the will for something hated but willed for the sake of something else that is loved in itself. ${ }^{135}$

In defense of God's creation of hateful things as a means to things that $\mathrm{He}$ loves, Ibn Taymiyya observes the need to choose between contrary alternatives. At the human level, we understand that one cannot enjoy everything at once. The pleasure $(l a d h d h a)$ of eating precludes the pleasure of drinking at the same time. Listening to one thing prevents listening to another. One cannot simultaneously go on hajj and fight in jihad. Everything has its necessary concomitants. Similarly, even though God is powerful over all things, $\mathrm{He}$ cannot create contraries simultaneously in one place, and He cannot create a son before his father. God is bound to follow the rules of logic. Thus, if

\footnotetext{
${ }_{134}$ Minhāj, 3:188-190/2:36-7.

135 Minhäj, 3:163-4/2:30, 3:182/2:35, 3:207/2:41, 5:414/3:103; Iḥtitjāj, MF 8:362-3; and Jabr, MF 8:478.
} 
He creates obedience in some but not in others, it is for some wise purpose that could not have been achieved through some other means. ${ }^{136}$

In some places in Minhäj, the shaykh defines God's wise purpose itself as that which is willed and loved. He asserts, "[God] created creatures according to His wise purpose that He loves." ${ }^{137}$ Moreover, God creates things that He hates and loathes "for the sake of a wise purpose that He loves and is well pleased with." ${ }^{138}$ Elsewhere, he notes that these things are created with respect to their end (ghaya) and not for themselves, ${ }^{139}$ and this explains God's creation of satans and other detestable things. ${ }^{140} \mathrm{He}$ adds in Minhäj that God could have created everyone to be a believer but has not done so in His wisdom. He may know that that would have led to some end that He would have hated. ${ }^{141}$ Ibn Taymiyya does not speculate what that hateful end might have been. In keeping with his method of giving God the highest similitude, his aim is simply to suggest how it might be thought that God loves the wise purpose in what He creates.

\section{Conclusion}

This chapter has shown how Ibn Taymiyya polemicizes against three currents which he believes fail to hold God's creation and God's command in proper balance. First, he castigates the Qadarīs and the Mu'tazilīs for denying God's all-encompassing creation and falling into dualism by asserting that human beings are the creators of their own acts. Second, he charges the Jahmis, the Ash'aris and the Sufis with using God's creation and determination of human acts as an excuse to weaken adherence to the Law. Moreover, the shaykh alleges that Ibn 'Arabī and his followers not only annul human responsibility but also collapse the distinction between Creator and creature into a metaphysical monism that makes value judgments meaningless because everything is divine. In the treatise Shams, Ibn Taymiyya accuses both the Mu'tazilis and the Ash'aris of having fallen afoul of the belief that God's creation of human acts is incompatible with rational judgment of the ethical value of

\footnotetext{
${ }_{136}$ Minhāj, 3:183-6/2:35-6, 5:415-6/3:103-4. Cf. Jabr, MF 8:512-3.

${ }_{137}$ Minhäj, 5:408/3:102. Cf. Minhāj, 5:401/3:100.

${ }_{138}$ Minhäj, 5:411/3:102. Cf. Thulth, MF 17:99.

139 Ibtijajj, MF 8:363, in which Ibn Taymiyya also notes that the correct attitude of the Sufi gnostic ('arif) is to hate the unbelief and disobedience that God creates just as God hates it but to love God's wise purpose in creating these things just as God loves His wise purpose.

${ }_{140} \mathrm{Jabr}, \mathrm{MF} 8: 478$.

${ }_{141}$ Minhäj, 3:183/2:35.
} 
those same acts. The Mu'tazilis maintain that reason distinguishes good and bad human acts and that this precludes God's creation of these acts. For the Ash 'arīs, God's creation of human acts precludes rational discernment of the ethical value that God attaches to these acts. Ibn Taymiyya censures a third group consisting of poets, free-thinkers and the ethically lax, and he charges these with following Iblīs in making God's creation and command out to be contradictory and disparaging God's wise purpose and justice.

Beyond polemics, Ibn Taymiyya employs his hermeneutic of creation and command to give sense to diverse vocabularies found in the Qur'an and the wider religious discourse. Equivalent terms for expressing God's creation of all things include lordship, determination, will (mash $\vec{i} a)$, inspiration, power and the ontological words. Terms used on the level of command and prohibition include divinity, love, good pleasure, hate, the religious and legislative words and the distinction between piety and immorality. Moreover, Ibn Taymiyya identifies a number of words, including will (iräda), judgment ( $\mathrm{bukm}$ ) and decree ( $q a d \vec{a})$, which appear in the Qur'an in an ontological sense at some points and in a legislative sense at others. These various sets of terms indicate two distinct realms, that of God's determination of all things and that of human responsibility to obey God.

Ibn Taymiyya does not often address the rational difficulty in upholding creation and command simultaneously. However, especially in Minhäj, he does employ the juridical imperative to give God the highest similitude to show that God creating what opposes God's command need not be irrational. Citing various examples from human affairs, he argues that someone may have a wise purpose in commanding someone to do something but refrain from helping, or that someone may do something he hates out of love for a desirable end. While recognizing that these explanations do not fully explain the relation of God's creation to God's command, Ibn Taymiyya maintains that such worthy intentions are a fortiori ascribable to God. 


\section{CHAPTER FOUR}

\section{GOD'S CREATION OF ACTS IN THE HUMAN AGENT}

\section{Ibn Taymiyya's View of the Human Act in Prior Research}

Ibn Taymiyya's view of the human act has received considerably more scholarly attention than other aspects of his theology. Henri Laoust observes in his Essai that the shaykh criticizes the Ash'arī doctrine of acquisition $(k a s b)$ and sometimes admits secondary causality but that he also maintains God's full omnipotence. The result is an irresolvable duality of perspective: "Through theological reflection, the human being becomes more and more profoundly conscious of absolute determinism. He must, for the sake of the necessities of the social and moral life, willingly convince himself of his freedom." Laoust adds in a footnote that the shaykh often contradicts himself by affirming God's omnipotence and human freedom simultaneously. ${ }^{1}$ Laoust's observations are correct so far as they go, but they do not illumine Ibn Taymiyya's position fully.

More enthusiastically, Victor Makari finds Ibn Taymiyya's view of the human act "inescapably convincing" and "lucid and profound." Makari's commendation appears to derive from reading Ibn Taymiyya against the backdrop of causal chain theories attributed to the Ash'arī theologian alJuwaynī and the philosopher Ibn Rushd. ${ }^{2}$ While Ibn Taymiyya does employ the philosophical language of secondary causality, this chapter will show that these causes are not efficacious but only instruments in God's acts of creation. God creates all existents directly; human acts are not links in a causal chain headed by a First Cause. ${ }^{3}$

${ }^{1}$ Laoust, Essai, 166-7 and n. 4 (quote on 167). Laoust repeats the assessment that Ibn Taymiyya is ambiguous on the human act in Les schismes dans l'Islam (Paris: Payot, 1965), 400-401, as does Christian van Nispen, Activité Humaine et Agir de Dieu, 264-5.

${ }^{2}$ Makari, Ibn Taymiyyah's Ethics, 76-81 (quotes on 80).

3 Thomas Michel, A Muslim Theologian's Response to Christianity, 44-55, does not analyze Ibn Taymiyya's doctrine of the human act in detail, but he does demonstrate a historically significant point. The shaykh's criticism of the Ash'arī doctrine of divine determination for undercutting human responsibility adds a new dimension to the traditionalist Hanbalī censure of Kalām theology. Earlier Hanbalī polemicists had not condemned the Ash'́arīs for this.

(c) Jon Hoover, 2007

This is an open access chapter distributed under the terms of the http://creativecommons.org/licenses/by-nc/3.0/. 
Makari unfortunately does not take note of the earlier and far more thorough work of Daniel Gimaret. In a 1977 article on the human act in Hanbali thought, Gimaret devotes a section to Ibn Taymiyya's views in Minhäj and Iräda. ${ }^{4}$ Among the features of the shaykh's doctrine that Gimaret highlights are mediation between the Ash'aris and the $\mathrm{Mu}^{\prime}$ tazilīs, polemic against the Ash'ari doctrine of acquisition, assertion that human agency is both real and created by God and affirmation of some kind of secondary causality. Gimaret also briefly mentions the two kinds of divine will—ontological and legislative-which were treated in the previous chapter. Gimaret is impressed with Ibn Taymiyya's ingenuity and originality and with the degree to which he gives a role to human agency. ${ }^{5}$ However, Gimaret is rather less admiring in his 1980 book on the human act in Sunnism as a whole. He justifies his exclusion of the Hanbalis and Ibn Taymiyya from the book by stating that they did not make an original contribution to this doctrine in the Sunni tradition. In a short footnote Gimaret explains that when writing his earlier article on Hanbali views he was not aware of the extent to which Ibn Taymiyya had been inspired by the Ash'arī theologian Fakhr al-Dīn al-Rāzī. Unfortunately, Gimaret says no more about this linkage. ${ }^{6}$

The present chapter examines Ibn Taymiyya's views afresh, going beyond the work of Gimaret by drawing on a wider range of the shaykh's texts, clarifying how he is similar to al-Rāzì and showing that he is less comfortable than are both al-Rāzì and Ibn 'Arabī with compulsion ( $j a b r$ ) and paradox. First, however, more attention must be given to these and others among Ibn Taymiyya's predecessors.

\section{The Theological and Philosophical Context}

As is evident from the preceding chapter, the fundamental division in Islamic theological reflection on the human act turns on who creates and determines this act: God or human beings? Out of concern for God's justice in reward and punishment, the Mu' tazilīs maintain that humans create their own acts

${ }^{4}$ Daniel Gimaret, “Théories de l'acte humain dans l'école Hanbalite," Bulletin d'études orientales 29 (1977): 156-178.

5 Also, following Gimaret, "Théories de l'acte humain dans l'école Hanbalite," George Makdisi, "Ethics in Islamic Traditionalist Doctrine," 51-6, provides a brief exposition from Minhäj, showing that for Ibn Taymiyya God is the Creator while the human is the agent of the human act.

${ }^{6}$ Daniel Gimaret, Théories de l'acte humain en théologie musulmane (Paris: J. Vrin, 1980), x n. 3 . 
with libertarian freedom, that is, with freedom to choose apart from the decisive control of external determinants. Out of concern for the all-pervasive quality of God's power, the rest of the Islamic tradition affirms that God creates and determines the human act. Western philosophy of religion distinguishes determinism of this sort into two basic kinds. Hard determinism denies the human will any role in producing human acts; human freedom is an illusion. Soft determinism or compatibilist freedom gives significance to human action and will without granting libertarian freedom. In this latter view, human beings paradoxically exercise choice and are thereby morally responsible even though external causes fully determine their wills. ${ }^{7}$

The pure compulsion (al-jabr al-mahd) attributed to Jahm b. Safwān is the archetypal case of Islamic hard determinism. In this view, God not only creates and determines the human act but is also the act's sole Agent $\left(f_{a}^{-} i l\right)$. If humans may be said to act, it is only in a metaphorical sense. There is no difference between human acts and the movements of inanimate bodies or between voluntary and involuntary acts. God creates all of them equally. ${ }^{8}$

Some scholars portray Ibn Sīnā as a hard determinist or nearly so, while others argue that he makes room for human freedom. ${ }^{9}$ Ibn Sinnās best pos-

${ }^{7}$ For conceptual analysis of the notions libertarianism, compatibilism (i.e. soft determinism) and hard determinism which I introduce here, see Thomas P. Flint, "Providence and predestination," in A Companion to Philosophy of Religion, ed. Philip L. Quinn and Charles Taliaferro (Oxford, UK: Blackwell Publishers, 1997), 569-576.

${ }^{8}$ Gimaret, Théories de l'acte humain en théologie musulmane, 64-6. Gimaret adds that this view of Jahm's doctrine may need to be qualified from al-Ash'arī's Maqälät, which indicates that Jahm gives humans a power and a will in a sense resembling that of the Ash'ari doctrine of acquisition (kasb).

9 George F. Hourani, "Ibn Sinnās 'Essay on the Secret of Destiny," Bulletin of the School of Oriental and African Studies 29 (1966): 25-48, reads Ibn Sinna in a way that is very close to hard determinism. Opposing this are Alfred L. Ivry, "Destiny Revisited: Avicenna's Concept of Determinism," in Islamic Theology and Philosophy: Studies in Honor of George F. Hourani, ed. Michael E. Marmura (Albany, NY: State University of New York Press, 1984), 160-171; and Lenn E. Goodman, Avicenna (London: Routledge, 1992), 83-96. Nevertheless, favoring a hard determinist reading is Michot, La destinée de l'homme selon Avicenne, 61-63 n. 18, who observes that for Ibn Sinā humans produce their invocation of God only from "a certain point of view" (bi-wajh mā) while God produces the invocation "in reality" (bi-l-haqiqa). Humans can thus not be said to act in reality but only metaphorically. Yahya Michot, ed. and trans.,

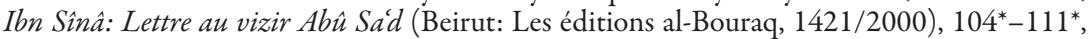
$120^{*}-129^{*}$ and $104-7$, translates and comments on several more strongly deterministic passages from Ibn Sīnā. Adding to his evidence for "le total déterminisme d'Avicenne" is Yayha Michot, ed. and trans., Avicenne: Réfutation de l'astrologie (Beirut: Les éditions al-Bouraq, 1427/2006), 61-71 (quote on 61), which translates additional relevant texts, mostly from Ibn Sinnäs al-Ta'lìqāt. More polemically, Inati, The Problem of Evil, 154-162, argues that Ibn Siña is a hard determinist no matter what he might say about human freedom. Abū Zayd, Mafhüm al-khayr, 183-191, also discusses Ibn Sīnās jabrism. Also, see now Catarina Belo, Chance and Determinism in Avicenna and Averroes (Leiden: Brill, 2007). 
sible world order in which all contingent existents are necessary by virtue of external causes leading back to the First certainly precludes libertarian freedom, but it goes beyond our present purposes to sort out whether Ibn Sināss determinism is hard, soft, or ambiguous and underdetermined. What is of interest here is that Ibn Sinnā speaks of free choice (ikhtiyār) in a way that has soft determinist or compatibilist potential and is employed by later thinkers including Ibn Taymiyya. In the following passage from al-Ta'liquat, Ibn Sinā explains that human beings perceive themselves to be choosing freely for their own purposes even though they are fully determined by external causes.

The [human] soul is necessitated in the form of one who chooses freely (al-nafs mudtarra fì șürat mukhtära), and its movements are also subject to subjection like natural movement. It depends on purposes ${ }^{10}$ and motives, and it is subjected to them, except that the difference between it and natural [movements] is that it perceives its purposes, and nature $\left(a l-\operatorname{tabi}^{-} a\right)$ does not perceive its purposes. ${ }^{11}$

Formulations of this kind find their way into the post-Avicennan tradition in the writings of al-Ghazālī, al-Rāzì, Ibn 'Arabī and, as we will see, Ibn Taymiyya. Al-Ghazālī for example writes in his Ihy $\vec{a}^{-}$'ulüm al-din that the human being is "compelled to choose freely (majbür 'alä al-ikhtiyär)," which means "his being compelled is that all [of his acts] occur in him from outside of him, not from him... [and] his freely choosing is that he is a substrate (maball) for a will which originates in him."12

Most Ash'arì theologians may be described as compatibilists, but they articulate this in different ways. In the view traditionally ascribed to alAsh'ari by later Ash'arīs, God is both Creator and Agent of the human act—as in the doctrine of Jahm b. Șafwān-but the human acquires this act with a power originated by God in the person. There is no causal connection between the power and the acquisition (kasb) of the act, and this power does not determine the act/acquisition in any respect. Yet, the power and the acquisition do establish human responsibility for acts. The Ash'arī theologian Bāqillānī takes a slightly different course, maintaining that the

${ }^{10}$ Reading aghräd instead of a'räd.

${ }^{11}$ Ibn Siñā, Al-Tálìquàt, 53.

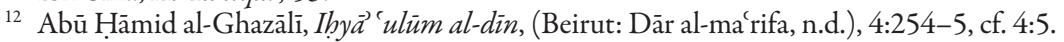
On al-Rāzì see further below in the present section. William C. Chittick, The Self-Disclosure of God: Principles of Ibn al-'Arabis' Cosmology (Albany, NY: State University of New York Press, 1998), 188-190, translates several examples of Ibn 'Arabîs affirmation that humans are compelled in their choosing from Futühät al-Makkiyya (e.g. 2:444 and 3:229). 
human power determines an attribute of the act, but other Ash'arīs, such as al-Juwaynī in his Irshād, and later al-Āmidī and $\overline{\mathrm{I}} \overline{\mathrm{j}} \mathrm{i}$, deny the human power any efficacy in the act, and this is the strict Ash'arī determinism that Ibn Taymiyya denounces. ${ }^{13}$

A second stream of Ash'ari thought on the human act is couched in causal terms. In al-Juwaynī's al-'Aqida al-nizämiyya, the human power is created by God to serve as an intermediate or secondary cause for His creation of the human act. ${ }^{14} \mathrm{Al}$-Shahrastānī sees in this the philosophers' doctrine of a chain of causes leading back to the First Cause, God. Gimaret hesitates to interpret al-Juwaynîs secondary causality along Neoplatonic lines of this kind because al-Juwaynī explicitly states that God creates the causes producing the human act directly. ${ }^{15}$

Similar uncertainty surrounds the interpretation of al-Ghazālì. There is little dispute that he employs Ibn Sinnās causal vocabulary, but its meaning is not entirely clear. According to Gimaret and Michael Marmura, al-Ghazālī is a strict Ash'arī denying causal efficacy between the human power and the human act. God creates each cause and each effect directly in the chain of causes and effects that constitute the world. While there is no efficient causality between causes, causes do function as conditions (sg. shart) upon which subsequent causes depend. In order for God to create the human will, there must be prior human knowledge; for knowledge there must be prior human life; for life there must a prior human body; and so on. In Marmura’s

${ }_{13}$ Gimaret, Théories de l'acte humain en théologie musulmane, 79-118, 154-6, 160-1. It is not entirely clear whether al-Ash'arī himself denied secondary causality between the human power and the acquired act. Arguing that al-Ash'arī did uphold secondary causality is Richard M. Frank, "The structure of created causality according to al-Aš arī: An analysis of the Kitäb al-Luma', pars. 82-164," Studia Islamica 25 (1966): 13-75. Refuting Frank's thesis is Binyamin Abrahamov, "A re-examination of al-Ash'arîs theory of kasb according to Kitäb al-luma', Journal of the Royal Asiatic Society 1989 ii: 210-221. Gimaret, Théories de l'acte humain en théologie musulmane, 79-92, detects weakness in Frank's thesis, but he also cites evidence for the possibility of secondary causality in al-Ash'arī. See additionally the survey of M. Schwarz, "Acquisition' (Kasb) in early Kaläm," in Islamic Philosophy and the Classical Tradition: Essays presented by his friends and pupils to Richard Walzer on his seventieth birthday, ed. S.M. Stern, Albert Hourani and Vivian Brown (Columbia, SC: University of South Carolina Press, 1973), 355-387.

${ }_{14}$ Imām al-Haramayn Abū al-Ma'ālì 'Abd al-Malik al-Juwaynī, Al-' Aqìda al-nizāmìyya, ed. Muhammad Zāhid al-Kawtharī ([Cairo]: Maṭba'at al-anwār, 1368/1948), 30-42.

15 Al-Shahrastānī, Kitāb nihāyatu 'l-iqdām fî̀ 'ilmi 'l-kaläm, ed. and English paraphrase Alfred Guillaume (London: Oxford University Press, 1934), 78 (Arabic), 35 (English). For full discussion, see Gimaret, Théories de l'acte humain en théologie musulmane, 120-8, who argues that al-Shahrastānī over-interprets al-Juwaynī. 
summation, "Ghazali... adopts Avicennan ideas. But these are reinterpreted and cast in Ash'arite occasionalist terms." ${ }^{16}$

Binyamin Abrahamov and Richard Frank read al-Ghazālī differently. They explain that al-Ghazālī adheres ultimately, but not explicitly, to a chain of natural cause and effect leading back to God as the First Cause and Sustainer, a chain in which God cannot intervene. To make sense of the inconsistencies in al-Ghazālī’s writings, Frank argues that al-Ghazālī is Ash'arī in outward allegiance and teaching while holding various Neoplatonic notions in his private belief. ${ }^{17}$ Frank's proposals have not escaped critique. Both Michael Marmura and Ahmad Dallal criticize Frank for misreading al-Ghazālìss texts and misunderstanding his terminology. ${ }^{18}$ This yet unresolved debate over al-Ghazālī well illustrates that Muslim theologians' use of causal language is subject to diverse interpretations. Ibn Taymiyya is a prime case in point. Whereas Makari reads the shaykh's theology of the human act in terms of efficacious and natural causality, I will show that, from the theological perspective at least, conditional or instrumental causality is the better interpretation.

A key figure in post-Avicennan Islamic theology and a frequent foil in Ibn Taymiyya's writings is the Ash'arī theologian Fakhr al-Dīn al-Rāzì. Gimaret explains that al-Rāzī is inspired by both Ibn Sinnā and the Mu'tazilīs in his approach to the causal relations involved in the human act. Yet, al-Rāzi reduces $\mathrm{Mu}^{\mathrm{c}}$ tazili libertarian freedom to either compatibilist freedom or compulsion. Al-Rāzì either does not speak about the traditional Ash'arī notion of acquisition or simply rejects it as a word without meaning. Moreover, al-Rāzì does not believe that proofs from the Qửan can give certain

16 Michael E. Marmura, "Ghazali and Ash'arism Revisited," Arabic Sciences and Philosophy 12 (2002): 91-110, especially 102-110 (quote on 108); and Gimaret, Théories de l'acte humain en théologie musulmane, 128-132. See also Michael E. Marmura, "Ghazali's Chapter on Divine Power in the Iqtisăd," Arabic Sciences and Philosophy 4 (1994): 279-315.

17 Binyamin Abrahamov, "Al-Ghazālī’s Theory of Causality," Studia Islamica 67 (1988): 75-98; and Richard M. Frank, Al-Ghazali and the Ash'arite School (Durham, NC: Duke University Press, 1994), 4, 20-1, 36-9, and 86-101. Frank states that for al-Ghazāli God in His custom cannot interrupt the "lawful operation of secondary causes" (20-1). Richard M. Frank, Creation and the Cosmic System: Al-Ghazâlî and Avicenna (Heidelberg: Carl Winter Universitätsverlag, 1992), 47-82, and 86, gives detailed support for this assessment and argues that al-Ghazālī adopts the optimism and natural necessitarianism of Ibn Sinnā despite incompleteness in his theology and his rejection of numerous "inconsequential" theses of the philosopher.

${ }_{18}$ Michael E. Marmura, "Ghazālian Causes and Intermediaries," Journal of the American Oriental Society 115 (1995): 89-100, responds to Frank's Creation and the Cosmic System. Ahmad Dallal, "Ghazali and the Perils of Interpretation," Journal of the American Oriental Society 122.4 (2002): 773-787, reviews Frank's Al-Ghazāli and the Ash' arite School. 
knowledge on the question of the human act because the sacred text may be used to prove either the Qadarī or the Jabrī theses. Only rational proofs are decisive. ${ }^{19}$

Al-Rāzỉs primary rational proof is the preponderator (murajjib) argument, which we have already seen Ibn Taymiyya use to prove the existence of God and refute the arguments of the philosophers and the Kalām theologians on the origin of the world. Gimaret credits al-Rāzì with having invented this argument even though the terms murajih, rujhän (preponderance), and their cognates go back to Ibn Sīnā and the Mu' tazilī theologian 'Abd al-Jabbār (d. $415 / 1025)$. To begin the argument, al-Rāzì presupposes with the Mu'tazilīs that God creates the human power by which the human acts. In the Mu'tazili conception, this power is a power to perform either an act or its contrary. $\mathrm{Al}-\mathrm{R}$ àzì argues that there is nothing to "tip the balance" for this human power in favor of one of the two equally possible acts. The human power cannot preponderate out of itself. It requires a preponderator that makes one act preponderate (räjiḥ) over the other. So, al-Rāzì maintains, God must supply this preponderator. Thus, the human act comes into existence by means of a human power and a preponderator, both of which God creates. ${ }^{20}$

Gimaret suggests that al-Rāzì devises the preponderator argument to embarrass the Mu'tazilīs by drawing out what he believes to be their implicit determinism. The Jubbāì Mu'tazilīs, among them 'Abd al-Jabbār and his student Abū al-Husayn al-Bașrī, maintain that voluntary human acts arise not only from human power but also from a motive $\left(d_{\bar{a}}^{-} \bar{\imath}\right) .{ }^{21}$ Like al-Rāzī, Gimaret claims that this Mu'tazili doctrine leads inevitably to determinism since the motive that God creates determines the act. Richard Frank and Wilferd Madelung have both refuted Gimaret in the case of 'Abd al-Jabbār, for whom, they say, the motive does not necessitate the act. Frank does not

19 Gimaret, Théories de l'acte humain en théologie musulmane, 134-140. In discussing alRāzī, Gimaret draws extensively, but not exclusively, from a manuscript of al-Rāzīs Al-Mațālib al-äliyya. The material on the human act is now found in the ninth part of the published edition. Also, see now Shihadeh, Teleological Ethics, 13-44, for a more detailed treatment of al-Rāzìs theology of human action than that provided by Gimaret. Shihadeh clarifies that al-Rāzī did adhere to the traditional Ash'arī doctrine of acquisition in his earliest works but abandoned it later on. Additionally, according to Shihadeh (10 n. 34), the ninth part of the edited Al-Matälib al-äliyya is rather a separate and earlier work called Al-Jabr wa al-qadar.

${ }^{20}$ Gimaret, Théories de l'acte humain en théologie musulmane, 140-1.

${ }^{21}$ Gimaret, Théories de l'acte humain en théologie musulmane, 39-60. For a detailed history of the followers of Abū 'Alī al-Jubbā'ī and especially those of his son Abū Hāshim (the Bahshamiyya), which include 'Abd al-Jabbār and Abū al-Husayn al-Bașrī, see Margaretha T. Heemskerk, Suffering in Mu'tazilite Theology: 'Abd al-Jabbarr's Teaching on Pain and Divine Justice (Leiden: Brill, 2000), 13-71. 
speak to the case of Abū al-Husayn, but Madelung contends that he also, albeit with difficulty, retains the non-necessitating character of motives and factors of preponderance in bringing about the human act. For Abū al-Husayn, it is human choice that decides the act. ${ }^{22}$ These clarifications aside, it remains that al-Rāzī imputes to Abū al-Husayn the doctrine that the motive is necessitating, and, as Gimaret explains, he draws out the logical conclusion of compulsion ( jabr). The motive necessarily brings the act into existence. Otherwise, the act would require another motive prior to it, and so on ad infinitum. The stark choice is thus between compulsion and determinism on the one hand and denying the Creator on the other. Al-Rāzi chooses compulsion and the Creator, and, unlike his Ash' arī predecessors, he does not hesitate to call himself a Jabri. ${ }^{23}$

Apart from anti-Mu'tazilì polemic, al-Rāzì conceives the operation of the human act in compatibilist terms with parallels in the Mu'tazili psychology of voluntary action. The human is the agent of his act, but God creates and determines the act. When the motive combines with the power that is equally powerful for an act and its contrary, then the act becomes necessary. Gimaret notes that al-Rāzī sometimes calls the motive an intention (qașd) or a will (iräda or mashì $a$ ). He also speaks of the decisive will (al-mashì a al-jäzima) that brings the act into existence necessarily. The human being acts by his will, but God creates this will. Accordingly, employing a formula like those of Ibn Sinnā and al-Ghazālī noted above, al-Rāzī affirms, "The human being is necessitated in the form of one who chooses freely (al-insān mudtarr fi sürat mukbtär)."24

In addition to this compatibilism, a passage in al-Rāzìs Tafsìr finds him underlining the contradictory character of human agency. ${ }^{25}$ Al-Rāzì sets out his comments when interpreting the verse: "God has sealed the hearts [of the

${ }^{22}$ Wilferd Madelung, "The Late Mu'tazila and Determinism: The Philosopher's Trap," in Yäd-näma in memoria di Alessandro Bausani, ed. Biancamaria Scarcia Amoretti and Lucia Rostagno, vol. 1, Islamistica (Rome: Bardi, 1991), 245-257; and R.M. Frank, "The Autonomy of the Human Agent in the Teaching of 'Abd al-Ğabbar," Le Muséon 95 (1982): 323-355. Frank points out that the "psychological determinism" that Gimaret imputes to the Jubbā'is runs counter to the fundamental Mu'tazili concern for justice. See also al-Julaynad, Qadiyyat al-khayr wa al-sharr, 185-6, for an exposition of 'Abd al-Jabbār's thought on motives that corresponds to the analyses of Frank and Madelung.

${ }_{23}^{23}$ Gimaret, Théories de l'acte humain en théologie musulmane, 142-5.

${ }^{24}$ Gimaret, Théories de l'acte humain en théologie musulmane, 145-9 (quote from al-Rāzī, Al-Mațälib al-'áliyya, 9:25).

${ }_{25}$ Fakhr al-dīn al-Rāzī, Al-Tafsìr al-kabìr li-l-Imām al-Fakhr al-Rāzì, 3d ed. (Cairo: Mu'assasat al-mațbū āt al-islāmī, n.d.), 2:52-3. Gimaret, Théories de l'acte humain en théologie musulmane, $152-3$, provides a partial translation of this passage, as does Shihadeh, Teleological Ethics, 38-9. 
unbelievers] and their hearing" (Q. 2:6). After concluding that the quranic evidence on the human act falls into the realm of contradiction ( hayyiz al-ta' $\bar{a} r u d$ ), al-Rāzi turns to the rational arguments of the Ash'arīs-whom he calls Sunnīs-and the Mu'tazilīs. He first notes that the Shäfíi jurist Abū al-Qāsim al-Anșārī (d. 512/1118) argues that neither Mu'tazilīs nor Sunnīs (i.e. Ash'arīs) should be called unbelievers on this matter because both exalt God. Al-Rāzī explains that Sunnīs emphasize God's greatness and say that God must be the sole Creator (müjid) while Mu'taziliss stress God's wisdom (bikma) and say that it is unbefitting of God's sublimity to commit

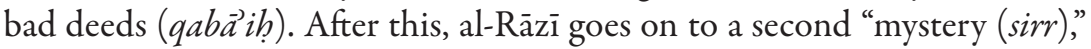
this time dealing with the cause of the human act. On the one hand, he writes, "Establishing the Divinity leads necessarily to the view of compulsion ( jabr)." On the other, "Establishing the Messenger leads necessarily to the view of [human] power." In the latter view, that of the Mu'tazilis, God's guidance through the Messenger Muhammad entails human accountability and human power to commit acts. Al-Rāzì proves the contrary compulsion position with his preponderator argument. Acts that are merely contingent or possible (mumkin) require a preponderator (murajib existence. God must create this preponderator. So, denying that human acts require a preponderator is tantamount to denying the Creator, but affirming a preponderator entails compulsion and determinism in human acts and is tantamount to denying the Messenger. Al-Rāzì then outlines a third mystery. We intuitively sense a need for a preponderator to determine something's existence or nonexistence, but, following the logic of the previous mystery, this insight leads to compulsion in human acts. Conversely, we know intuitively that there is a difference between voluntary and involuntary acts, between the good of praise and the bad of blame, and between command and prohibition. This entails the doctrine of the Mu'tazilīs. Al-Rāzì concludes that it seems as though the dictates of reason and the exaltation of God's power and wisdom lead into the realm of contradiction, and he closes his discussion by asking God to lead us to truth and to good ends. In this text, al-Rāzī pits Mu'tazilī libertarian freedom against compulsion and makes no attempt to render the two perspectives compatible. ${ }^{26}$

${ }^{26}$ Al-Rāzī, Al-Mațälib al'-äliyya, 8:118, observes the same contradiction or opposition ( $\left.t a^{\prime} \bar{a} r u d\right)$ and indicates that it is obligatory for ordinary people (al-awämm) not to delve into it. Shihadeh, Teleological Ethics, 181-203, provides a sensitive discussion of al-Rāzīs late-life skepticism concerning apodictic knowledge in metaphysical and theological matters. 
Three somewhat different outlooks may be detected in the above review of al-Rāzīss thought on the human act. First, he calls himself a Jabrī, openly confessing compulsion ( $j a b r$ ) in human acts and reducing Abū al-Husayn al-Bașiñs libertarianism to compulsion as well. Second, he articulates a compatibilism in which the human being is the agent of his act while God creates the act by creating the power and the decisive will through which the act comes into existence. Third, al-Rāzì in his Tafsìr stresses the contradiction between libertarian freedom and compulsion and makes no attempt to articulate their compatibility.

In some sense, Ibn 'Arabì picks up where al-Rāzī leaves off. For the Sufi theorist, proofs from revelation contradict each other, and while the Mu'tazilis and the Ash'arīs both make strong and valid rational arguments-the first based on God's command, the second based on God's power-their views are contradictory as well. With Ibn 'Arabī, ambiguity is the fundamental character of reality, and all perspectives-even if contradictory-have their proper validity. So, in this question as in others, it is perhaps missing the point to try to pin Ibn 'Arabi down to one position or another. Nonetheless, he does say that the truth of this matter is found only through unveiling (kashf $)$ and that this gives greater credence to the Ash'ari view. Ultimately, the gnostic sees that all acts are God's acts and that there is no linkage between secondary causes or between the human power and the human act. At most, the acquisition or performance $(k a s b)$ of the act is attributed to the human being, and this is his free choice (ikhtiyarr). ${ }^{27}$

As the following sections will bear out, Ibn Taymiyya resists the drift toward open admission of contradiction characteristic of al-Rāzì and Ibn 'Arabī and refuses to surrender claim to rationality in the face of this most intransigent of theological paradoxes. Working within a metaphysical framework developed in al-Rāzî̀s theology, Ibn Taymiyya holds fast to the compatibility of human agency and God's preponderance of human acts. This, as well as his polemic against Jabrīs and strict Ash'arīs, explains why Ibn Taymiyya may look-in Gimaret's words_-"much more anti-Ash'arì than anti-Mu'tazilì,"28 even though the underlying metaphysic is fully deterministic.

\footnotetext{
27 Chittick, The Sufi Path of Knowledge, 205-211, translates several texts pertaining to the human act from Ibn 'Arabī's Futubät al-makkiyya (especially 3:403 translated on 208).

${ }^{28}$ Gimaret, "Théories de l'acte humain dans l'école Hanbalite," 166.
} 


\section{Ibn Taymiyya on the Compatibility of Divine Creation and Human Action}

\section{God Is the Creator, Originator and Preponderator of the Human Act}

Ibn Taymiyya supports the view that God is the Creator of human acts with quranic verses such as, "[Abraham and Ishmael said,] 'Our Lord! Make us (ij'aln $\bar{a})$ submissive to You and of our progeny a nation submissive to You'" (Q. 2:128), "We made ( $\left.j a^{\prime} a l n \bar{a}\right)$ leaders from among them guiding under our command" (Q. 32:24), and, "Surely, the human being was created (khuliqa) fretful, when evil touches him, anxious, when good touches him, grudging" (Q. 70:19-21). ${ }^{29}$ For rational proof that God is the Creator of the human act, Ibn Taymiyya turns to al-Rāzī’s preponderator argument and an equivalent originator argument. The shaykh uses these extensively in Minhäj to counter the Mu'tazilism of al-Hillī.

One full and clear version of the originator argument proceeds as follows. Ibn Taymiyya first notes that the human will or act originates after not existing. Now, he argues, an originating event either has an originator or it does not. If it does not, then we have origination without an originator. If the act has an originator, it must be either the human, or God, or someone else. If it is the human, then the act's originator itself requires a prior originator and so on ad infinitum. This is impossible because an infinite regress of originating events cannot subsist in humans who are themselves originated. If the originator of the act is someone else, the same difficulty of an infinite regress recurs as when the originator is the human himself. Therefore, God must be the Creator and Originator of the human act and will. ${ }^{30}$

The preponderator argument has already been presented from al-Rāzī above, and its details need not be repeated here. For Ibn Taymiyya, it yields the same result as the originator argument. ${ }^{31}$ The shaykh occasionally even interchanges the terms 'origination' and 'preponderance' in the course of the same argument. ${ }^{32}$ The upshot of the preponderator and originator arguments is that God creates, preponderates or originates human acts directly by supplying the complete cause that makes the respective act necessary.

${ }^{29}$ Minhāj, 3:110/2:17, 3:153/2:28, 3:237/2:48, 3:258ff./2:54ff.; Ibtạl, MF 2:322; MF 8:78-9; and Dar', 1:68-9.

${ }_{30}$ Minhāj, 3:236/2:48.

${ }_{31}$ Minhāj, 3:118-9/2:19, 3:236/2:49, 3:268-9/2:57-8.

${ }^{32}$ Minhāj, 3:30-1/1:270, 3:116-8/2:18-9. 
For Ibn Taymiyya, there is also no essential difference between voluntary and involuntary human acts from the perspective of God's creation. He explains that God creates human acts "through the intermediary of His creation of the servant's will and his power just as $\mathrm{He}$ creates the effects by their secondary causes (asbāb). He creates clouds through wind, rain through clouds, and plants through rain." ${ }^{33}$ More will be said about secondary causality later in this chapter. Here it suffices to note that the modes of God's creation in the moral and natural spheres are identical, the only difference being that human will and power are the relevant intermediaries in the moral realm. Moreover, all human activities are contingent upon God's will to create them. In support of this, Ibn Taymiyya frequently cites the verse, "To whomsoever among you wills to go straight: You will not unless God, the Lord of the worlds, so wills" (Q. 81:28-9)..$^{34} \mathrm{He}$ explains that this verse affirms against the Jabrīs that humans have a will and against the Qadarīs that this will is dependent upon the will of God..$^{35} \mathrm{He}$ also notes that belief in the human will is vital for belief in command and prohibition, promise and threat, while belief in God's will is central to belief in determination. ${ }^{36}$ Nonetheless, he maintains that the human will and power are totally dependent upon God's creation for their operation. ${ }^{37}$ Ibn Taymiyya discusses human power and will often, although not always precisely. The following two sections analyze this discourse further.

\section{Determining Power and Legislative Power}

Ibn Taymiyya uses several terms to indicate power in humans: power (qudra), capability (istițā $a$ ), ability (țāqa) and strength or potency (quwwa). Power and capability occur most commonly. All four of these terms are used

\footnotetext{
${ }^{33}$ Minhāj, 3:146/2:26.

${ }_{34}$ Wäsitiyya, MF 3:150; Iräda, MF 8:118; MF 8:238; Qadāa , MF 8:268; Istițā'a, MF 8:374; Kasb, MF 8:393; Jabr, MF 8:459, 488; and Minhäj, 3:111/2:17, 3:236/2:48.

$35 \mathrm{Jabr}, \mathrm{MF} 8: 488$.

36 MF 8:240.

37 The following passage in Minhäj, 3:269/2:57, illustrates Ibn Taymiyya's view of God's complete causality in the creation of human acts: "Since the act of the servant does not occur except by a preponderator from God-Exalted is $\mathrm{He}$ - and upon the existence of this preponderator the existence of the act is necessary, his act is like the rest of the originating events that originate by means of secondary causes that God-Exalted is $\mathrm{He}$-creates. The existence of the originating event is necessary with them. This is what it means for the Lord-Blessed is $\mathrm{He}$, and exalted is $\mathrm{He}-$ to be Creator of the act of the servant. The meaning of that is that God-Exalted is $\mathrm{He}-$ creates the complete power and the decisive will in the servant. Upon their existence, the existence of the act is necessary because this is the complete cause for the act. When the complete cause exists, the existence of the effect is necessary."
} 
synonymously in the course of four pages in the third volume of the edited Minhajj..$^{38}$ In Dar' the shaykh says similarly that the "capability" of the human "is his power and his ability." ${ }^{39}$ Ibn Taymiyya speaks of two kinds of power in humans. On the one hand is "the legislative power that is the factor of [bodily] soundness (musabhib) for the act which is the crux of command and prohibition" 40 or "the power that is the condition for imposing obligation (al-qudra al-mashrüta fi al-taklif $).{ }^{\prime \prime 1} \mathrm{On}$ the other hand is "the determining power necessitating the act which is conjoined to the thing empowered and is not posterior to it." ${ }^{42}$ The shaykh also calls the latter the power that makes the act follow necessarily (mustalzim). The power that is a factor of soundness is both before and with the act, and it is a condition (shart) for the act to take place. The necessitating power comes into force at the very time of the act and not prior to it. ${ }^{43}$ Capability falls into the same two types as noted in a passage from the brief fatwa Istiț $\bar{a}^{\top} a$ :

Capability is of two kinds: anterior and effectual for two opposites, and conjoined and only with the act. [The first] is the soundness factor for the act and the admissibility factor (mujawwiza) for it. [The second] is the necessitating factor for the act and the realization factor (mubaqqiqa) for it. ${ }^{44}$

In a number of texts, the shaykh uses a few key quranic verses and hadith to illustrate the soundness factor senses of both capability and power. He quotes, for example, "It is the duty of people to God to take the Pilgrimage ( ( ajj) to the House, whoever is capable of making his way there" (Q. 3:97). He argues that if this were the capability conjoined to the act, then the obligation of the Pilgrimage would fall only on those actually taking the Pilgrimage. In this case, those with requisite means for the Pilgrimage would not be disobeying if they did not take it. ${ }^{45} \mathrm{He}$ also quotes the hadith in which the Prophet says, "When I have commanded you with a command, do of it what you are capable." ${ }^{46}$ This capability is not conjoined to the act.

${ }^{38}$ Minhāj, 3:47-50/2:274-5. See also the interchangeable usage of qudra and istiț $\bar{a}$ in Iräda, MF 8:129; Istițā' $a$, MF 8:371; and $T_{a}^{-r} a$, MF 8:441-2.

39 Dar', 1:60.

40 Iräda, MF 8:129.

${ }^{41}$ Minhāj, 3:103/2:15.

${ }_{42}$ Iräda, MF 8:129.

${ }_{43}$ Minhāj, 3:50/1:275, 3:71/2:6, 3:103/2:15. Cf. Minhāj, 3:47/1:274.

${ }^{44}$ Istițā' $a$, MF 8:372. Cf. Minhäj, 3:48-50/1:274-5; Dar', 1:60-1; Sáāda, 8:290-1; and Abū Dharr, MF 18:172-3.

45 Iräda, MF 8:129; Istițā' $a$, MF 8:372; and Minhāj, 1:407-8/1:114.

${ }^{46}$ Bukhārī, 6744, Al-I'tiṣāam bi-l-kitāb wa al-sunna, Al-Iqtidā̄ bi-sunan rasūl Allāh; Aḥmad, 9158. 
Otherwise, the hadith would mean that they were commanded to do only what they did. ${ }^{47}$ As examples of the conjoined and necessitating capability, the shaykh cites, "They were not capable of hearing, and they were not seeing” (Q. 11:20), and, "Those whose eyes were covered from My Reminder, and they were not capable of hearing" (Q. 18:101)..$^{48}$ Ibn Taymiyya adds in Istița $\bar{a}^{-} a$ that the first type of capability is legislative and the second ontologi$\mathrm{cal}$, and he ties these to the commanding, legislative words and the creative, ontological words, respectively, which we observed in Chapter Three. ${ }^{49}$ The shaykh's two senses of capability thus correspond to God's command and creation, respectively.

Ibn Taymiyya attributes his doctrine of the two senses of power and capability to "those who grasp the full truth among the Kalām theologians, jurists, hadith specialists and Sufis." ${ }^{50} \mathrm{He}$ reports that the Mu'tazilis and their followers among the $S^{-1} 1$ is affirm only the soundness factor type of human power while the Ash'arīs and others grant only the necessitating power. The former group insists that humans could do other than what they do. The human power is effectual for either an act or its opposite. However, the shaykh says that this violates the principle of preponderance. The latter group says that humans can do only what they actually do. Human power is only effectual for and conjoined to the act it creates. Ibn Taymiyya notes, however, that some from this latter group uphold the former type of capability when working in the realm of jurisprudence. ${ }^{51}$

\section{Imprecision in the Human Will}

In view of the fact that Ibn Taymiyya conceives the conjoined power or capability to be immediately effectual in producing the human act, the place of the will is not apparent. Further investigation shows that the shaykh's psychology of human action becomes imprecise when pressed beyond the basic distinction between power as the bodily soundness to perform an act and the complete cause that brings the act into existence.

We begin with several passages solely from Minhäj to demonstrate Ibn Taymiyya's variety of expression. One passage sets out will and power in

${ }^{47}$ Iräda, MF 8:129; and Istițā $a$, MF 8:372-3.

${ }^{48}$ Istițä́ $^{\mathrm{r}}$, MF 8:373; and Dar', 1:61.

49 Istițā $a$, MF 8:373. Cf. Iräda, MF 8:129-131.

50 Dar', 1:60.

${ }^{51} I s t i t \overline{a ̆}^{-} a$, MF 8:371; Abū Dharr, MF 18:173; Sáäda, MF 8:290, 292; Dar', 1:60; and Minhāj, 1:408-9/1:114. On jurists adhering to an anterior capability in jurisprudence but not in theology, see Iräda, MF 8:130. 
equivalent terms. Without giving names, the shaykh notes that people dispute over the "choosing agent (al-fấ il al-mukhtār)." Is his will before the act, conjoined to the act, or both? Likewise, is power prior to the act, conjoined to the act, or both? The shaykh then gives what he believes to be the correct view: "The decisive will (al-iräda al-jäzima) with the complete power (al-qudra al-tämma) make the act follow necessarily and are conjoined with it. The act does not come to be by an unconjoined prior power only or an unconjoined prior will only." 52 Ibn Taymiyya observes that before the act there may be power but not will, or will but not power. There may also be resolve ('azm). Then he writes, "When the time for the act comes, the resolve strengthens and becomes an intention (qasd). The will at the time of the act is more perfect than it was before it, and likewise, the power at the time of the act is more perfect than it was before it." ${ }^{53}$ Although this discussion holds will and power in perfect symmetry, there is no attempt to explain how the two are related or whether they are identical.

A second passage in Minhäj eliminates power as a necessitating factor in the act and gives this role solely to will. After noting that some say that the power is before the act and others say that it is conjoined to it, Ibn Taymiyya articulates his own view:

The power is the factor of soundness only, and it is with it and before it. As for [the factor] making it follow necessarily, it only occurs upon the existence of the will with the power, not by the very thing that is called power. The will is not part of what is called the power. This view is the one agreeing with the language of the Qur'an and, moreover, the language of the rest of the nations. It is the most correct of the views. ${ }^{54}$

At a later point in Minhāj, the shaykh distinguishes will from power in similar terms. Power is the condition for imposing obligation, but will is not. Rather, the will is the condition for the existence of the act. ${ }^{55} \mathrm{~A}$ fourth passage just a little earlier in Minhāj gives less prominence to the will. After explaining the two views that power is either before the act or at the time of the act, Ibn Taymiyya claims that there is both a power prior to and extending up to the time of the act and a second power necessitating the act. The power existing prior to the act is not sufficient to make someone believe or disbelieve. God must single out the believer with special blessing and produce

\footnotetext{
${ }_{52}$ Minhāj, 1:407/1:113.

53 Minhäj, 1:407/1:113-4.

${ }^{54}$ Minhäj, 3:71-2/2:6.

${ }^{55}$ Minhäj, 3:106/2:16.
} 
his will to believe. This will is part of "the entirety of the power conjoined with the act." ${ }^{156}$ Here, the will has been subsumed under the power that is complete and produced directly by God. In a fifth passage from Minhäj, Ibn Taymiyya says that the human act follows necessarily when the decisive will and the complete potency (al-quwwa al-tämma) combine (ijtama ${ }^{C}$ ). He then explains that what brings an act into existence is the complete cause (al-illa al-tämma) which is necessarily conjoined to the act and not prior. ${ }^{57}$

Beyond Minbāj, there are a number of other texts presenting similar diversity. A discussion of necessitating capability in $D a r^{\prime}$ construes capability as will. Ibn Taymiyya notes that the Salaf interpret the verse, "They were not capable of hearing, and they were not seeing" (Q. 11:20), to mean that something - in this case hearing and seeing-is not possible, not due to a lack of power but a lack of will. The shaykh writes, "Their souls were not capable of willing it, even though they had the power to do it if they had so willed. This is the state of one whose caprice or corrupt opinion diverted him from listening to the books of God sent down and following them." 58 Elsewhere, Ibn Taymiyya says that a decisive will is needed to make an act necessary, but he also allows that this will falls under the ensemble of factors constituting the conjoined capability. ${ }^{59} \mathrm{~A}$ brief passage in Kasb subsumes not only will but also every other cause that may be involved in the production of an act under the conjoined power: "Power here is absolutely nothing but an expression of that from which the act [comes] with respect to intention, will, soundness of [body] members, created potency in the limbs, etc. Therefore, it must be conjoined with the act." ${ }^{\text {0 }}$

In short Ibn Taymiyya maintains one power that is the soundness of the human body for performing acts that is the condition for God's imposition of obligation. He also upholds a second power-variously called will, power, capability or some combination thereof-that generates the human act and is created directly by God. Beyond this, nothing more precise may be said about how the shaykh conceives the psychology of human action.

56 Minhāj, 3:104.

57 Minhāj, 3:50/1:275.

58 Dar', 1:61.

$59 T \vec{a} a$, MF 8:441-2.

${ }^{60}$ Kasb, MF 8:390. 


\section{Reconciling the Jabris and the Qadaris with Compatibilist Freedom}

Ibn Taymiyya occasionally articulates the compatibility of human accountability with God's creation of human will and power by reconciling the Ash'arī Fakhr al-Dīn al-Rāzī with the Mu'tazilī Abū al-Husayn al-Bașrī. In Minhāj, the shaykh quotes a passage from al-Rāzī’s $A r b a^{\prime}$ in in which the Ash 'arī theologian accuses Abū al-Husayn of contradiction. On the one hand, al-Rāzī argues, Abū al-Husayn goes to the extreme in Mútazilism by asserting that it is necessary knowledge that humans bring their acts into existence $(\bar{j} j a d)$. On the other, Abū al-Husayn falls into extreme Jabrism because he holds that the occurrence of the act is dependent on a motive $\left(d \bar{a}^{-} \bar{\imath}\right)$, which al-Rāzì understands as necessary to preponderate the existence of the act. ${ }^{61}$ Ibn Taymiyya accuses the Shīīs Nașîr al-Dīn al-Ṭūsì (d. 672/1274) and Ibn al-Muțahhar al-Hillì of the same contradiction that al-Rāzī finds in Abū al-Husayn. ${ }^{62}$

Despite this accusation, Ibn Taymiyya goes on to use al-Rāzīs deterministic reading of Abū al-Husayn's motive theory to argue, sophistically it will appear, for the compatibility of the Mu'tazilī and Ash'arì viewpoints. He maintains that Abū al-Husayn's theory is equivalent to the teaching of the majority of Sunnīs, and he claims that al-Juwaynī, the Hanbalī Abū Khāzim b. Abū Ya là (d. 527/1133) and the Karrāmīs come close to this position. ${ }^{63}$ The existence of human power alone is inadequate for an act to become preponderate. A motive, that is, a complete preponderator, must be conjoined to this power for the existence of the act to become necessary. ${ }^{64}$ According to the shaykh, the Mu'tazilis err only when they claim that the motive arises apart from God's will and power. ${ }^{65}$

Ibn Taymiyya also uses the deterministic interpretation of Abū al-Husayn al-Bașrī to reconcile two data of necessary knowledge that Fakhr al-Dīn al-Rāzì took to be contradictory. As in the passage translated below from Istiț $\bar{a} a$, the shaykh affirms first that it is necessary knowledge that voluntary acts are attributed to the human who is their agent and originator (mubdith). Second, he contends that it is necessary knowledge that human will and action require an originator or preponderator from God. Thus, Ibn Taymiyya

${ }^{61}$ Al-Rāzī, Arbàìn, 1:319, quoted in Minhāj, 3:251/2:52.

${ }^{62}$ Minhāj, 3:247-250/2:51-2, 3:276/2:58-9. Ibn Taymiyya, Minhäj, 3:273/2:58, also mentions that, unlike Abū al-Husayn, the Mu'tazilī al-Zamakhsharī does not adhere to the necessitating quality of the preponderator.

${ }_{63}$ Minhäj, 3:239/2:49, 3:251/2:52, 3:268/2:56.

${ }_{64}$ Minhäj, 3:31/1:270, 3:74/2:7, 3:239/2:49, 3:267-8/2:56.

${ }_{65}$ Minhäj, 3:75/2:7. Cf. Minhāj, 3:248/2:52. 
maintains that both the Qadarīs and the Jabrīs have part of the truth on the human act. The human act truly exists, and it is fully dependent upon God for its existence. Unlike al-Rāzī, he claims that the necessary knowledge of voluntary human agency is not incompatible with the necessary knowledge of the need of the human act for a preponderator, and he sees no contradiction in this ${ }^{66}$ Here is his argument in full:

The Qadarīs and the Jabrīs separate into two contradictory sides. Each of them is correct in what it establishes but not in what it denies. Abū al-Husayn al-Bașrī and whoever follows him among the Qadaris claim that the knowledge that the servant originates ( $y u b d i t h)$ his acts and his actions is necessary knowledge and that denying that is sophistry.

Ibn al-Khațīb [Fakhr al-Dīn al-Rāzī] and his like among the Jabrīs claim that the knowledge that preponderating the servant's act over his not acting requires a preponderator apart from the servant is necessary. [This is] because one of the two positions of something which is possible and has two equal positions will not become preponderant over the other except with a preponderator.

Both of these views are correct. However, the claim that the necessary implication of one of them is to deny the other is not correct. The servant is originating his acts [and] acquiring (kassib) them, and this origination is in need of an originator. The servant is acting, fabricating $\left(s a \bar{a} n i^{\top}\right)$ and originating, and his being acting, fabricating and originating after he was not [thus] must inevitably have [another] agent. As He said, "To whomsoever among you wills to go straight"-When he wills to go straight, he begins going straight. Then, He said- "You will not, unless God, Lord of the worlds, so wills" (Q. 81:28-9).

All of what is known necessarily and what traditional $\left(\operatorname{sam}^{\mathrm{C}} \bar{i}\right)$ and rational ('aqlī) proofs demonstrate is true. Therefore, there is neither might nor power except by God. The servant needs God. [He has] an essential need for Him in his essence, his attributes, and his acts. Nonetheless, he still has an essence, attributes and acts. ${ }^{6}$

It is apparent that Ibn Taymiyya effects his reconciliation of Fakhr al-Dīn alRāzī and Abū al-Husayn al-Baṣrī in this passage by reading the term originate ( yubdith) in a much different sense from the usual Mu'tazilī sense of create. In Istit tata, from which this passage is taken, the shaykh does not elaborate how humans may be said to originate their acts, but he does broach this question in Minhājj. There he explains that God's origination (ihdāth) of acts means that He creates them disjoined from Himself and subsisting in humans whereas human origination (ihdatth) of acts means that acts originate

${ }^{66}$ See similar discussions in Shams, MF 16:235-7, and Minhäj, 3:235-240/2:48-9.

${ }^{67}$ Istițā $^{\top} a$, MF 8:375. 
( hadatha) from humans by their will and power which God creates. ${ }^{68}$ Thus, human origination of acts does not involve human creation of acts for Ibn Taymiyya as it would for the Mu'tazilīs. The shaykh follows al-Rāzì in insisting on God's preponderance of the human act, and he maintains the compatibility of this with human accountability by replacing a libertarian account of human agency with the simple existence of a human agency willed and created by God. Ibn Taymiyya maintains that human beings have acts that exist in reality just as they have essences and attributes that are real, but, if human beings may be said to have choice and freedom in the shaykh's thought, it is strictly in a compatibilist sense.

\section{The Substrate Principle: Humans Are the Agents of their Acts in Reality}

In a number of texts and especially in Minhäj, Ibn Taymiyya distinguishes between God who creates the human act $\left(f^{\prime} l\right)$ and the human who is its agent $\left(f_{\bar{a}} \mathrm{i} i\right)$ by limiting attribution of the act to the substrate (mahall) (i.e. the human) in which it subsists. The shaykh draws this distinction to counter the Mu'tazili objection that a God who creates acts of disobedience is bad and unjust. ${ }^{69}$ God cannot be called to account for creating bad acts because $\mathrm{He}$ creates them in a substrate other than Himself, namely, human beings, and $\mathrm{He}$ is not qualified by them. By virtue of this 'substrate principle', only the substrate is qualified by the acts subsisting in it. ${ }^{70}$

The shaykh explains that God's creation of acts in humans is like God's creation of their attributes. God creates some black and some white, some tall and some short, and so on. So also, He creates some believing and some disbelieving, some unjust and some oppressed. In each of these cases, it is not God but humans who are qualified by what He creates. God is not black or white, tall or short, believing or unbelieving but only the humans in whom He creates these things. ${ }^{71}$

From the human perspective, humans are the agents of their acts in reality (haqiqatan) — not metaphorically as Jahm b. Șafwān would have it—by virtue of what God has created to subsist in them. Humans act by their will, power

${ }^{68}$ Minhāj, 3:239-240/2:49.

${ }^{69}$ See for example Minhäj, 1:455-460/1:126-7, 2:294-5/1:213, 3:137-154/2:24-8; Iräda, MF 8:122-7; and Abü Dharr, MF 18:151-5. Cf. Jabr, MF 8:468-9.

${ }_{70}$ Minhāj, 1:455-7/1:126, 3:110/2:17, 3:146/2:26, 3:148/2:26; Iräda, MF 8:119-127; and Jabr, MF 8:483-4. Cf. Gimaret, "Théories de l'acte humain dans l'école Hanbalite," $176-7$.

${ }_{11} \mathrm{Jabr}$, MF 8:483-4; Kash, MF 8:403; Abū Dharr, MF 18:155; and Minhāj, 1:4557/1:126, 2:294-5/1:213. Cf. Minhäj, 3:217-220/2:43-4. 
and free choice (ikhtiyarr), and judgments for their acts are attributed to them and not to God. ${ }^{72}$ Ibn Taymiyya suggests that if things that cannot choose may even be said to come from a certain place-as fruit from a certain tree or a crop from a particular plot of ground - then acts are a fortiori attributed to those with free choice, even though God is their Creator. ${ }^{73}$ As the shaykh puts it in one discussion of the human act, "The Qur'an has informed that servants believe, disbelieve, act, commit deeds, acquire, obey, disobey, pray, give alms, undertake the Hajj, undertake the 'Umra, kill, commit adultery, steal, tell the truth, lie, eat, drink, fight and wage war." ${ }^{34}$ Thus, both acts of obedience and disobedience are attributed to humans, and humans thereby become worthy of reward and commendation or punishment and blame. ${ }^{75}$

Passages employing the substrate principle often include polemic against the ideas that God's creation (khalq) and act $\left(f^{\prime} l\right)$ are identical to the thing created $(m a k b l \bar{u} q)$ and the thing enacted $\left(m a f^{\prime} \bar{u} l\right)$, respectively. ${ }^{76}$ Ibn Taymiyya attributes these views to Jahm b. Șafwān, al-Ash' 'arī and their followers in the four Sunnī schools of law including the Hanbalīs Ibn 'Aqīl and Ibn al-Jawzī. ${ }^{77} \mathrm{He}$ explains that their intention is to avoid saying that the human act has two agents (i.e. God and the human). ${ }^{78}$ But he counters that one must distinguish an act from the thing enacted and creating from the thing created. Thus, the human act is the act of the human in reality and a thing created and enacted by God. God creates the act, but He does not commit the act. If it is said that the act $\left(f^{\prime} l\right)$ is His, it means that it is enacted $\left(m a f^{\prime} \bar{u} l\right)$ by Him in another. The shaykh attributes this view to Sunnīs generally on the report of the Shāfíi jurist al-Baghawī (d. 510/1117), to Sufis on the report of al-Kalābādhì (d. 380/990 or 384/994), and to a number of Hanbalis. He also tells us that it was the last of two positions held by Abù Yálā, and he attributes it to the Hanafî law school, possibly

${ }^{72}$ Minhäj, 3:12/1:265, 3:109/2:17, 3:145/2:26, 3:148-9/2:26, 3:257/2:54; Wäsitịyya, MF 3:150; Iräda, MF 8:118, 123; Jabr, MF 8:459, 482-3; and Abü Dharr, MF 18:151-5.

${ }^{73}$ Minhāj, 3:145-6/2:26.

${ }^{74} \mathrm{Jabr}, \mathrm{MF}$ 8:459. See also Wäsitiyya, MF 3:150; Iräda, MF 8:120; MF 8:237-8; and Minhāj, 3:111-2/2:17. See Minhāj, 3:256-265/2:53-6, 3:336-9/2:74-5, for an extended listing and discussion of quranic texts indicating both that humans commit acts and that God creates them.

${ }^{75}$ Minhäj, 3:153-4/2:28.

${ }^{76}$ Iräda, MF 8:118ff.; Jabr, MF 8:468; and Minhäj, 1:458-460/1:127, 2:296ff./1:213ff., 3:13/1:266, 3:112/2:17, 3:240-1/2:49-50, 5:426-7/3:107.

${ }_{77}$ Minhāj, 1:457/1:127, 2:296-7/1:213-4, 3:112/2:17; and Jabr, MF 8:428. Ibn Taymiyya also reports in Minhāj, 2:296/1:213, 3:240/2:59, that the Ash'arī theologian Abū Ishāq al-Isfarāyinī (d. 418/1027) taught that the single act had two agents (i.e. God and the human).

${ }^{78} \mathrm{Jabr}, \mathrm{MF}$ 8:428. 
having in mind the Māturīdī school of theology that was prominent among the Hanafis. ${ }^{79}$ Gimaret notes that Ibn Taymiyya's distinction between the act and the thing enacted corresponds to the Māturīdi theological position, and he suggests that Ibn Taymiyya or an earlier Hanbalī, such as Abū Yálā, may have borrowed this idea from the Māturìdiss. ${ }^{80}$

In view of the substrate principle, Ibn Taymiyya maintains that God is not unjust in what He creates. As for why God would create unbelief and disobedience, Ibn Taymiyya asserts that God has wise purposes in this. ${ }^{81}$ In Minhāj the shaykh also provides a fortiori arguments to defend God's retributive justice further. He argues that, if a human is not unjust to punish his servant for injustice that God creates, then God Himself is a fortiori not unjust to punish injustice that $\mathrm{He}$ creates. Likewise, if someone is not considered unjust to chastise another when that is necessary to gain a certain benefit, then God Himself is a fortiori not unjust to do the same. ${ }^{82}$ In a similar argument just a little later in Minhäj, Ibn Taymiyya explains that this is in keeping with the God who is not like anything, but Who, in His right to perfection, is given the highest similitude. ${ }^{83}$ These arguments and the substrate principle that lie behind them may not have satisfied Ibn Taymiyya completely. In Hasana, which will be examined in the next chapter, he goes beyond the substrate principle and attempts to absolve God of responsibility for creating bad deeds by locating the ultimate cause of human disobedience in nonexistence.

\section{Ibn Taymiyya's View of Divine Creation by Means of Secondary Causes}

\section{An Overview of Secondary Causality}

As was noted previously, Ibn Taymiyya says that God creates the human act by means of human will and power just as $\mathrm{He}$ creates plants in the natural

79 Minhāj, 1:457-8/1:127. Cf. Minhāj, 2:298-301/1:214, 3:112/2:17, 3:149/2:27. Ibn Taymiyya, $T_{a}{ }^{\prime} a$, MF 8:438, identifies Abū Manșūr al-Māturīdī as a Kalām theologian among the Hanafis. In Iräda, MF 8:120-3, Ibn Taymiyya gives a detailed account of the act $\left(f^{\prime} l\right)$ /thing enacted $\left(m a f^{\prime} \bar{u} l\right)$ distinction, but the early part of this passage is confusing and may be textually corrupt. Two lines that appear in MF 8:121 (mid-line 4 to mid-line 6) are lacking in the MRM and MRK1 versions of the text. Moreover, the two lines in question include the key term musamma al-masdar, which appears to be used inconsistently in the wider context.

${ }^{80}$ Gimaret, "Théories de l'acte humain dans l'école Hanbalite," 177-8.

${ }^{81}$ Abü Dharr, MF 18:155; Minhäj, 3:148/2:27; Iräda, MF 8:123; and MF 8:238.

${ }^{82}$ Minhäj, 3:148/2:26.

${ }^{83}$ Minhāj, 3:150-1/2:27. 
world through secondary causes like clouds and rain. Yet, what exactly is meant by secondary causality? In Tadmuriyya the shaykh gives an overview of his views on this that is translated below. This will serve as the basis for exploration of this question in other texts, especially in Kasb, which contains much illustrative material. In Tadmuriyya Ibn Taymiyya affirms that God is Creator, Lord and Sovereign of all things and that He is powerful over all things and knows all things. Nothing occurs apart from His will (mash $\vec{i} a)$. The shaykh continues:

Along with this, [the People of Guidance and Prosperity] do not deny what God creates of secondary causes ( $a s b \bar{b} b$ ) by which He creates effects (musabbabāt). For example, $\mathrm{He}$-Exalted is $\mathrm{He}$ - said, "[It is He Who sends the winds... . till when they have carried a heavy-laden cloud. We drive it to a land that is dead. Then We send down rain to it, and thereby We bring forth every kind of fruit" (Q. 7:57). He-Exalted is $\mathrm{He}-$ said, "By [the Book] God guides whoever follows His good pleasure to ways of peace" (Q. 5:16). He-Exalted is $\mathrm{He}-$ said, "By [this parable], He leads many astray, and by it He guides many" (Q. 2:26). Thus, $\mathrm{He}$ informed that $\mathrm{He}$ acts by means of secondary causes.

Whoever [e.g. a strict Ash'arī] says that $\mathrm{He}$ acts with them ('indahā) and not by means of them (bih $\bar{a})$ opposes what the Qur'an has brought and denies what God has created of potencies $(q u w \bar{a})$ and natures $\left(t a b \vec{a}^{-} i^{i}\right)$. This is similar to denying what God created of potencies that are in living beings by which living beings act, like the power of the servant. Likewise, whoever [i.e. a Mu'tazilī] makes them the creators of that has given associates to God and attributed His act to another.

That is because there is no cause among the causes but that needs another cause for its effect to occur, and there must inevitably be an impediment (māni $)$ impeding what is entailed by it (muqtadähu) when God does not repel [the impediment] from the [cause]. There is not one thing in existence that does anything independently when it wills, except God alone. He-Exalted is $\mathrm{He}-$ said, "And of everything We have created pairs, that you might remember" (Q. 51:49), that is, that you may know that the Creator of the pairs is one.

Therefore, whoever [e.g. Ibn Sinnā] says that from God only one [thing] emanates because nothing emanates from one but one is ignorant. ${ }^{84}$ Indeed, there is no one thing in existence from which emanates anything alone-neither

\footnotetext{
${ }^{84}$ According to Ibn Sinnā, only unity can flow from the One (i.e. God) so as to preserve the utter simplicity of the One. Since the One cannot be the source of multiplicity, multiplicity arises from the First Intellect, which emanates from the One. For further discussion, see Ibn Sīnā, Al-Tàlìqät, 54, 99-100; Ian Richard Netton, Allah Transcendent (Surrey, UK: Curzon Press, 1989), 162-7; and Nicholas Heer, "Al-Rāzī and al-Ṭūsī on Ibn Sīnās Theory of Emanation," in Neoplatonism and Islamic Thought, ed. Parviz Morewedge (Albany, NY: State University of New York Press, 1992), 111-125. Ibn Taymiyya argues in Iräda, MF 8:134, that Ibn Sinās One is devoid of attributes and ultimately has no existence outside the mind.
} 
one [in number] nor two-except God who created all the pairs among what the earth makes to grow, their souls, and what they do not know.

Burning does not occur except by the fire in which God created heat and in a substrate receptive to burning. When [fire] falls on a phoenix, sapphire and such like, it does not burn them, and a body may be coated with something that prevents it from burning. As for the sun from which rays come, there must inevitably be a body that receives the reflection of the rays upon it. When there is an obstacle such as a cloud or a roof, the rays do not pass below it. ${ }^{85}$

In other texts, Ibn Taymiyya gives numerous examples of God's creation through secondary causality. God may create market price rises by means of (bi-sabab) human injustice and price drops by means of human beneficence. ${ }^{86}$ God may grant humans their provision by the usual means of human endeavor or by the rarer means of angels and jinn. ${ }^{87}$ God may make an eclipse or a strong cold wind a cause of chastisement. ${ }^{88}$ God may make the celestial bodies (kawakib), the blowing of the wind, and the light of the sun and the moon secondary causes of originating events in the earth. ${ }^{89}$ Also, invocation and intercession are among the secondary causes by which God brings to pass what He decrees. ${ }^{90}$ Marriage and sexual intercourse are the divinely established customary causes of begetting children. ${ }^{91}$ God has made deeds causes of reward and punishment just as He has made poison a cause of illness and illness a cause of death. ${ }^{92}$

\section{Polemic on Secondary Causality}

The Tadmuriyya passage translated above includes polemic, first, against those who say that God creates only with or at ('ind) the instance of the causes, but not by $(b i)$ them, and, second, against those who give human power the

\footnotetext{
${ }^{85}$ Tadmuriyya, MF 3:112-3.

${ }^{86}$ MF 8:520.

87 Tawakkul, MF 8:534.

${ }^{88}$ MF 35:176. Yahya J. Michot, "Ibn Taymiyya on Astrology: Annotated Translation of Three Fatwas," Journal of Islamic Studies 11.2 (2000): 147-208, translates the fatwa on astrology found in MF 35:166-190. Cf. Qawl ' Alī, MF 8:172.

${ }^{89}$ Mantiqiyyin, 270 and MF 25:198-9, both of which are translated in Yahya Michot, "Pages spirituelles d'Ibn Taymiyya: XIII. Contre l'astrologie," Action (Mauritius), January 2001, 10-11, 26 (the passage from Mantiqiyyin is at 10 n. 4).

90 Wāsiț, MF 1:137. Wāsița, MF 1:121-138, is translated in full in Yahya J. Michot, "Ibn Taymiyya: Les intermédiaires entre Dieu et l'homme (Risâlat al-wâsita bayna l-khalq wa l-haqq)," Le Musulman (Paris) Special Issue (1996). Cf. MF 8:192-3.

${ }^{91} S a^{\prime} \bar{a} d a$, MF 8:276; and MF 8:68.

92 Qad $\vec{a}$, MF 8:268. Cf. Sá $\bar{a} d a$, MF 8:278-9. See also the listings of quranic verses indicating secondary causality in Minhäj, 3:113-4/2:18; and Irāda, MF 8:137-8.
} 
ability to create acts. The former charge is leveled against the tradition of strict Ash'arism in which whatever appears to be causally connected is simply a matter of God creating things conjoined at the same place and time. The human act does not occur by means of human power, but only with it. ${ }^{93}$ The latter charge is directed against the $\mathrm{Mu}^{\prime}$ tazilīs who argue that humans must create their own acts in order to be held properly accountable for them and also to free God from creating evil deeds. For Ibn Taymiyya, however, this is tantamount to giving God an associate (shirk) in His creative enterprise, and it must be rejected because God is the sole Creator. A discussion of secondary causality in Iräda adds a third charge. ${ }^{94}$ While some deny causes as the means by which God creates, others disregard causes that God has commanded such as invoking God and performing righteous deeds. The latter think that whatever God determines will happen whether or not they do what God has commanded. The shaykh counters this with two exchanges found in the Hadith:

[Some asked the Prophet], "Should we not leave deeds and trust completely on what has been written?" He said, "No! Perform deeds! Each is facilitated into that for which he was created"... It was said, "O Messenger of God! Have you seen medicine by which we may be cured, charms by which we may invoke [God], and piety (taqwā) by which we may fear [God]? Do they ward off anything of God's determination?" He said, "They are part of God's determination." 95

Ibn Taymiyya adds furthermore that God makes one thing a cause of another and that what God has determined has been determined to happen by means of secondary causes. In summing up these positions in Iräda, Ibn Taymiyya cites a saying, which he elsewhere attributes to al-Ghazālī and Ibn al-Jawzī in their writings on complete trust (tawakkul): ${ }^{96}$

Turning to the causes (asbäb) is giving associates in [violation of God's] uniqueness (shirk $f i$ al-tawbid). Obliterating the causes by denying that they are causes is an aberration with respect to reason. Abandoning the causes entirely is defamation of the Law. ${ }^{97}$

${ }_{93}$ For this see also Minhäj, 3:239/2:49; Iräda, MF 8:136-7; Bughya, 35; and Michot, "Ibn Taymiyya on Astrology," 155-6 and n. 34, which translate MF 35:168 and MF 9:287-8, respectively.

${ }_{94}$ Iräda, MF 8:138-9.

${ }^{95}$ Iräda, MF 8:138. The first hadith is found in Bukhārī, 4568, Tafsīr al-Qur'ān, Fa-sanuyassiruhu li-l-'usrāā, and the second in Ibn Māja, 3428, Al-Ṭibb, Mā anzala Allāh dāan an illā anzala lahu shifā'.

${ }_{96}$ The attribution to al-Ghazālī and Ibn al-Jawzì is found in Bughya, 35.

${ }^{97}$ Irāda, MF 8:138-9. 
In the context of this dictum in Iräda, it appears that the Mu'tazilis are those "turning to the causes" in their attribution of the creation of acts to humans. The strict Ash'arīs "obliterate" the causes, and those who fail to do what God has commanded because of determination "abandon" the causes. The shaykh also mentions this aphorism in other places with minor changes of wording, but its interpretation is not always apparent. ${ }^{98}$ In one text, however, he gives an extended discussion that clarifies what he thinks it means. "Turning to the causes" is depending upon them and putting one's hope in them. For Ibn Taymiyya, there is no cause worthy of this because all causes depend upon God for their origination. Nothing originates itself. Here he criticizes the philosophers and the astrologers at length for believing that the motions of the nine celestial spheres are the causes of all originating events. ${ }^{99} \mathrm{He}$ also identifies the naturalists and the Mu'tazilis with this first part of the aphorism. Moving to its second part, he notes that "obliterating the causes" is not only an imperfection in reason but also defames the Law, and he identifies this position with many of the Kalām theologians, presumably the Ash'aris. ${ }^{100}$ Regarding the third part, the shaykh says that "abandoning the causes entirely" is not only "defamation of the Law" but also irrational, and he censures those who think their deeds play no role in what will happen to them because of divine determination. ${ }^{101}$ For Ibn Taymiyya, the first part of the aphorism negates God's creation and the last two parts undercut the Law.

\section{Secondary Causality from the Divine Perspective Is Instrumental}

A key point in the Tadmuriyya quotation above is that the secondary causes by which God creates do not in themselves have the ability to entail their effects. No secondary cause can act alone. Examples from Kasb clearly illustrate that the causes are thus purely instrumental from God's perspective. Ibn Taymiyya notes that God punishes via human effort: "Fight against them; God will chastise them by your hands" (Q. 9:14). Then, he explains that "our hands are the secondary causes, the instruments (ālät), the intermediaries (awsāt) and the tools (adawät) in bringing the chastisement to

98 Wāsița, MF 1:131; Tuhfa, MF 10:35; MF 8:70; Qawl'Alī, MF 8:169; Tawakkul, MF 8:528; MF 10:256; and Bughya, 35. I am indebted to Michot, "Ibn Taymiyya: Les intermédiaires entre Dieu et l'homme," 8 (including n. 12), for the first two references.

99 Oawl' Alì, MF 8:169-173.

100 Oawl' Alì, MF 8:175.

101 Qawl'Alì, MF 8:175-8. 
them." 102 In Kasb he also illustrates the efficacy ( $\left.t a^{2} t h i r\right)$ of human power on the human act with the images of a pen writing, an adz hewing and a stick striking. ${ }^{103}$ The pen, for example, is not considered an associate (sharik) in the act of writing. The implication is that God has no associates in creating the human act. Nevertheless, the shaykh maintains that the effect (athar) of the pen cannot be ignored, and it is said that the act is performed by or with $(b i)$ it. Here the shaykh adds in passing that God is given the highest similitude. ${ }^{104}$ Apparently, he is alerting the reader that he is not necessarily describing the very modality of God's action but simply trying to speak well of it in accord with the principle of giving God the highest human perfection, as I have described in Chapter One. Following through on the pen and stick similes a little later in Kasb, Ibn Taymiyya fields the objection that no one has ever seen a writer's pen rewarded or a striker's stick punished. The images obviously fail him at this point, and he does no more than divert attention from the divine perspective to the human. He asserts that humans are agents in reality and do indeed have a will. He adds that every reasonable person knows intuitively that there is a difference between someone praying or committing adultery and someone shivering from fever, that is, there is a distinction between voluntary (ikhtiyāri $)$ and involuntary (idtirāra $\bar{i})$ acts. ${ }^{105}$

The shaykh's integration of God's guidance into the scheme of secondary causes also illustrates their instrumentality. The passage from Tadmuriyya quoted earlier cites an example from the Qur'an: "By [the Book] God guides whoever follows His good pleasure to ways of peace" (Q. 5:16). The Book, that is, the Qur'an, is a means by which God guides. ${ }^{106}$ In Kasb Ibn Taymiyya explains further that God's command is a secondary cause distinguishing obedience from disobedience. It is part of the ensemble of causes that brings God's determination of human destinies to fruition in happiness or punishment. The command in itself does not necessitate an obedient act,

\footnotetext{
102 Kasb, MF 8:390.
}

103 See also Iräda, MF 8:134, where Ibn Taymiyya explains that the efficacy of the human power is that of secondary causality and condition (shart ); and similarly, Minhäj, 3:1145/2:18. Al-Ghazālī, Ihyyà' 'ulūm al-dìn, 4:247-252 (in Kitāb al-tawhị̣̂ wa al-tawakkul), employs the image of the pen esoterically to point beyond humanity to God as the sole agent in the universe. Ibn Taymiyya uses the pen image somewhat differently both to point to God's agency and to secure a role for human agency and obligation to the Law.

${ }_{104}$ Kasb, MF 8:391. Cf. Kasb, MF 8:392. In Nubuwwāt, 81ff., Ibn Taymiyya elaborates on God's creation by means of other things and on how something created from matter is greater in servitude than something created from nothing (especially bottom of 89). Ibn Taymiyya's belief in perpetual creation from pre-existing matter was noted above in Chapter Two.

105 Kasb, MF 8:393-4.

106 Tadmuriyya, MF 3:112. 
but it is the instrument that determines whether an act is an act of obedience or disobedience. ${ }^{107}$

In other texts, Ibn Taymiyya gives additional discussion on the dependence of the secondary causes on other causes and of these on the will of God. He notes that fire cannot burn, food cannot fill the stomach, and drink cannot quench thirst by themselves. These things require at least one other secondary cause. Heat, for example, requires two causes. It requires the agent fire, and it requires a receptacle ( $q \bar{a} b i l)$, such as a body that is receptive to heat and burning. ${ }^{108}$ Rain cannot make plants grow without air, soil and other such things, and anyone who provides help is depending on a great number of other causes beyond his own power. ${ }^{109}$ According to the shaykh, there is ultimately no secondary cause and no created thing that can be a complete cause ('illa tämma or sabab tämm) entailing its effect necessarily. Everything is totally dependent on the will of God. It is God who perfects the combination of causes and conditions (shurüt) and removes impediments (mawānic) so that something comes into being. ${ }^{110}$ "If God does not make the causes perfect and repel the impediments, what is intended will not happen. What He-Glory be to Him-wills is, even if people do not will it, and what people will is not unless God wills." for example, that a couple engages in sexual intercourse in order to bear a child; God must also will to make the woman pregnant. Likewise, good deeds are a cause, but not a sufficient cause, of happiness; God must also grant His mercy and pardon. ${ }^{112}$

\section{Secondary Causality from the Human Perspective Is Natural}

Even though Ibn Taymiyya's dominant emphasis is that secondary causes are instrumental and cannot bring effects into existence apart from God's will,

${ }^{107}$ Kasb, MF 8:402. Ibn Sīnā explains the causality of commands and prohibitions in much the same way in Risäla fi sirr al-qadar, 29 (Arabic) and 32 (trans.), in George F. Hourani, "Ibn Sinä's 'Essay on the Secret of Destiny,'” 25-48.

108 Irāda, MF 8:133.

109 Qawl 'Ali, MF 8:167.

110 MF 8:70; Irāda, MF 8:133; Jabr, MF 8:486-7; Mahabba, 24; Qawl' Alī, MF 8:167-8; Minhāj, 3:115/2:18; and Abū Dharr, MF 18:179. Note also from Minhāj, 3:13/1:266: "God-Exalted is He-is the Creator of the cause and the effect. Although He is the Creator of the cause, it must inevitably have another cause sharing with it, and it must inevitably have an obstacle impeding it. Its effect is not complete-even though God created it-unless God creates another cause and removes the impediments."

111 Wāsița, MF 1:137.

112 MF 8:70. 
he nonetheless often presents them as having certain and predictable effects once activated by that will. As stated in the long passage from Tadmuriyya quoted earlier, fire burns whatever is receptive to burning, and roofs and clouds necessarily block the rays of the sun. ${ }^{113}$ Also, Ibn Taymiyya's assertion in the same text, "There must inevitably be an impediment impeding what is entailed by [the cause]," strongly suggests that causes automatically entail effects apart from impediments. ${ }^{114}$ The implication is that once God removes impediments the causes are free to exercise their efficacy in a natural causal fashion, at least from the human perspective. Once the cloud is removed (by God's will), the sun's rays will naturally heat the earth. Here God's direct willing of every event begins to recede from the picture. In Kasb the shaykh presents human deeds and recompense in a similarly naturalistic fashion. After discussing the divine side of the human act at some length in this fatwa, Ibn Taymiyya turns to the human basis of reward and punishment:

Know that God-Exalted is $\mathrm{He}$-created the act of the servant to be a cause entailing praiseworthy or blameworthy effects $(\bar{a} t h \bar{a} r)$. A righteous deed like prayer... is followed immediately by light in [the servant's] heart, gladdening in his chest, tranquility in his soul, increase in his knowledge, confirmation in his certainty, strength in his reason, and other than that. [This includes] the strength of his body, the splendor of his face, his renouncing abomination and wrong, fostering love for him in human hearts, repulsion of trials from him and other things that he knows and we do not know. Furthermore, these effects of light, knowledge, certainty and otherwise, which occur to him, are secondary causes leading to other effects of the same kind, of another kind higher than these, and so on. Therefore, it has been said that from the reward of a good deed is a good deed after it and that from the punishment of an evil deed is an evil deed after it. One who commits an evil deed like lying, for example, is punished immediately by darkness in the heart, hardness and tightness in his chest, hypocrisy, restlessness, forgetting what he has learned, blocking of the door to knowledge he was seeking, a decrease in his certainty and reason, disgrace, hatred of him in human hearts, boldness in other sin of the same kind or of a different kind, and so on, unless God sets him right by His mercy. ${ }^{115}$

This naturalistic account of reward and punishment shifts the focus from God's all-pervasive will to the responsibility of humans for their destiny. Yet, its naturalism involves a kind of inevitability in the results of acts, and this shifts the focus back to God who set up this cause and effect world. The

113 Tadmuriyya, MF 3:113. Cf. Minhāj, 3:270/2:57, where Ibn Taymiyya notes that when God creates fire in a garment there will be burning thereafter.

114 Tadmuriyya, MF 3:112.

115 Kasb, MF 8:396. Cf. Minhäj, 3:27-8/1:269 for similar notions of the natural effects of good and evil deeds. 
shaykh goes on in Kasb to explain that God has bound certain causes to certain effects with a "firm bond (rabt mubkam)" such that, from the perspective of creatures, the operation of the secondary causes is that of natural causality. Someone who eats gets full. Someone who drinks quenches his thirst. Yet, this account, even from the human perspective, is not entirely naturalistic. According to Ibn Taymiyya, God can break these causal bonds if He wills. He can take the potency out of food or place an impediment in the stomach. He can even make people full and quench their thirst by some other means if $\mathrm{He}$ so wills. However, humanity cannot violate the causal bonds that God has arranged. No one can eat without getting full or drink without satisfying his thirst. ${ }^{116}$ Following this in Kasb, Ibn Taymiyya attributes everything to God's wise purpose. God has a wise purpose in sending His messengers, and $\mathrm{He}$ has a wise purpose in creating the secondary causes and effects. Yet, the shaykh in Kasb also relates everything back to God's vanquishing power, operational will and even pre-eternal knowledge. God's determination is a mystery $(s i r r)$. It is enough to know that God is "All-Knowing, All-Wise and All-Merciful." 117

\section{Conclusion on Secondary Causality}

To sum up this overview of secondary causality in Ibn Taymiyya's thought, God's perspective appears to be that of a real but inert world of tools and raw materials that is wholly dependent upon God's will for its every movement. God creates by means of these instruments in accord with His wise purpose. The human perspective is that of a world of naturalistic cause and effect and reward and punishment into which God can intervene at any point. The language of secondary causality does not resolve the rational difficulty that God's all-encompassing will poses for free human agency and moral accountability. The shaykh's comparison of human agency to the writing of a pen successfully models instrumental causality from God's perspective, but it fails to make sense of voluntary human agency. When Ibn Taymiyya is faced with the injustice of an instrument like a pen being punished for what it writes, he can do no more than switch from the divine to the human perspective. In the course of his argument, he simply stops trying to explain how God creates human agency, and he appeals instead to rational intuition of the differences on the human level between acts that

116 Kasb, MF 8:397. Cf. Sáāda, MF 8:284.

117 Kasb, MF 8:398-9. 
are good and bad, and voluntary and involuntary. Despite such rational difficulties, Ibn Taymiyya's notion of secondary causality provides him with a powerful rhetorical tool for speaking of the compatibility of the divine and human spheres and for identifying error in those who he believes falter in one of the two domains.

\section{Ibn Taymiyya on Controversial Kalām Terms Relating to Human Agency}

\section{No Ash'arī Acquisition (kasb) and No Independent Efficacy (ta'thïr)}

This and the following two sections examine what Ibn Taymiyya writes about certain controversial terms and issues in the Kalām tradition, namely, human efficacy $\left(t a^{\prime} t h i r\right)$ in acts, human acquisition (kasb) of acts, God's obligation of what humans are not able to do (taklîf $m \bar{a}$ là yutāq), and compulsion ( jabr). Laoust and Gimaret both note that Ibn Taymiyya rejects the Ash'arī view of acquisition, and this will be reviewed below. ${ }^{118}$ However, they do not mention that the shaykh still employs the term to refer to the act itself, as in, "The act is the acquisition." 119 Ibn Taymiyya also suggests that "acquiring" does not differ from saying that someone "acts, brings into existence, originates, fabricates, performs deeds, etc." ${ }^{120}$ The term also indicates to the shaykh that human acts have results. The act that God creates in the person is "an acquisition by which [the person] attracts profit to himself and by which he repels harm from himself." ${ }^{21}$ In Kasb Ibn Taymiyya links acquisition to the quranic verse, "What [the soul] has acquired is accounted to it, and what it has acquired is held against it" (Q. 2:286). Thereafter, he observes that acquisition appears as the act through which human beings gain what they need to develop from deficiency to perfection. ${ }^{122}$

\footnotetext{
118 Laoust, Essai, 166; and Gimaret, "Théories de l'acte humain dans l'école Hanbalite," 166.

119 Minhäj, 3:210/2:42.

${ }_{120}$ Iräda, MF 8:119. Cf. Iräda, MF 8:124 and Istitǟa $a$, MF 8:375.

${ }^{121}$ Minhäj, 3:146/2:26.

122 The passage from Kasb, MF 8:387, reads, "The acquisition is the act that brings profit or harm to its agent $\left(f_{\bar{a}} \mathrm{i} i\right)$, as $\mathrm{He}-$ Exalted is $\mathrm{He}$ - said, 'What [the soul] has acquired is accounted to it, and what it has acquired is held against it' (Q. 2:286). He-Glory be to Him-has made obvious that the soul's acquisition is for it or against it. People say, 'So-andso acquired property or praise or eminence.' Similarly, he profited from that. When servants are perfected by their acts and benefit from them-when they were created imperfect at the beginning of creation - establishing the secondary cause (sabab) is correct. Indeed, their perfection and their benefit come from their acts. The act of God-Glory be to Him and
} 
Ibn Taymiyya disparages the strict Ash'ari concept of human acquisition with the aphorism, "There are three things having no truth: the 'leap' of alNazuāàm, the 'states' of Abū Hāshim and the 'acquisition' of al-Ash'arī."123 The shaykh reports that for al-Ash'arī God is the Creator of the human voluntary act, which the human then acquires conjoined to his temporally originated power in the same substrate. The existence of the originated power distinguishes voluntary from involuntary acts. However, this power has no efficacy in bringing the act into existence, and the human being is not the agent of his act. The shaykh believes that this is irrational, and he explains that this comes very close to the complete denial of human power set forth by Jahm b. Șafwān. ${ }^{124}$ In Minhāj he writes,

As for the Jabrīs such as Jahm and his followers, according to them, the servant has no power at all. Al-Ash'arī agrees with them in meaning. He says that the servant does not have an efficacious power (qudra mu' aththira). He maintains something he calls a power, and he makes its existence like its nonexistence. Similarly for the acquisition that he maintains. ${ }^{125}$

Ibn Taymiyya asserts that merely conjoining the power to the acquisition without positing any efficacious link erases any distinction between the powerful and the impotent or between power and any other human attributes, such as life, knowledge or will. ${ }^{126}$ Moreover, there is then no difference between voluntary and involuntary acts. ${ }^{127}$

It was noted in the discussion of secondary causality above that the efficacy ( $\left.t a^{3} t h i r\right)$ that Ibn Taymiyya himself posits between human power and the act itself is not of the kind that produces effects independently. Independent causal efficacy is solely God's prerogative. Human power is rather a condition and a secondary cause for God's creation of the act. It is thus apparent that Ibn Taymiyya can criticize al-Ash'arī for no more than failing to maintain that human power is among the secondary causes by which God creates the

exalted is $\mathrm{He}-$ and His handiwork come from His perfection and His greatness. His acts come from His names and His attributes and are derived from them."

${ }_{123}$ Iräda, MF 8:128 and Dar', 3:444. A similar saying appears in Minhäj, 1:459/1:127, 2:297/1:214. For discussion of al-Nazzām's theory of the leap ( $t a f r a)$ in causal operations and Abū Hāshim al-Jubbā'î̀s doctrine of states (ahwāl) in God's attributes, see Wolfson, The Philosophy of the Kalam, 167-205 (Abū Hāshim) and 514-7 (al-Nazzām); and Gimaret, La doctrine d'al-Ash' arī, 54-8 (al-Nazzāàm), and 169-170 and passim (Ä̉ū Hāshim).

${ }_{124}$ Minhäj, 3:75/2:7, 3:109/2:16-7, 3:209/2:41-2; Iräda, MF 8:118-9; and Jabr, MF 8:467.

${ }^{125}$ Minhäj, 1:397-8/1:111.

126 Minhāj, 3:113/2:17-8.

$127 \mathrm{Jabr}, \mathrm{MF}$ 8:467; and Minhäj, 3:209-210/2:42. 
act. In this regard, the shaykh also rejects a third sense of efficacy proposed by al-Bāqillānī in which the human power is efficacious in determining an attribute or state of the act, but not the act itself. The shaykh says that this posits something-even if only an attribute-that falls outside the domain of God's creation. He argues that there is no difference between giving efficacy to a speck or an elephant apart from God. Both equally involve giving God an associate $\left(\right.$ shirk). ${ }^{128}$

Ibn Taymiyya has no difficulty employing the terms efficacy and acquisition according to his own senses despite the fact that he believes Ash'arī theologians have stripped them of meaning. However, the shaykh is much more reticent to say that God obligates humans to do what they are not able or that God compels them to act. As the next two subsections show, Ibn Taymiyya believes that these two ways of speaking, even if given correct senses, should not be used because they too easily suggest ideas that are inappropriate for God.

\section{No Obligation of What One Is Not Able to Do (taklīf mā lā yuṭāq)}

Closely connected to the issue of human power is that of the obligation of what one is not able to do (taklī $m \bar{a}$ la $y u t a \bar{q})$. On a number of occasions, Ibn Taymiyya notes that two different kinds of obligation come under this label. The first kind is obligating people to do what they have no power to do, as in obligating humans to fly, the blind to vocalize copies of the Qur'an, the chronically ill to walk or the sitting simultaneously to stand. The shaykh asserts that most Sunnīs, including most Ash'arīs, deny that this kind of obligation is found in the Law. The second kind is obligating people to do that of which they are capable in the sense of being sound of body and limb. However, the obligated does not commit the act because he lacks the will to do it and is preoccupied with something else. For example, an unbeliever could believe but does not do so because he is preoccupied by unbelief.

According to Ibn Taymiyya, the first kind of obligation of what one is not able to do does not occur, but the second kind does. However, he does not believe that the second kind should be given this label even though the Ash'arī theologian al-Bāqillānī, the Hanbalī Abū Ya'lā and many others do identify it as such. He explains that calling the second kind obligation of what one is not able to do is based on the Ash'ari principle that the human

${ }^{128}$ Kasb, MF 8:389; and Minhäj, 3:113/2:18. Cf. Minhāj, 3:268/2:56. For detail on alBāqillānīs view, see Gimaret, Théories de l'acte humain en théologie musulmane, $92 \mathrm{ff}$. 
power or capability to act is present only at the time of the act and is only for the act that actually takes place. Thus, all imposition of obligation prior to an act itself is obligating what is beyond human ability. ${ }^{129}$ Presupposing his doctrine of two capabilities, Ibn Taymiyya argues that this is not in keeping with the teachings of the Qur'an, the Sunna and the Salaf because the Qur'an explicitly states that God has obligated acts of which one is capable. This includes things like going on pilgrimage and fasting (cf. Q. 3:97, etc.) ${ }^{130}$

Ibn Taymiyya also addresses a more extreme version of obligation of what one is not able to do, that of al-Rāzi. ${ }^{131}$ The shaykh provides a full discussion of this in Jabr. For al-Rāzì, this doctrine is not just a matter of obligating something of someone who lacks potency, as in commanding the blind to see. Rather, God obligates what is rationally impossible, as in combining two contradictories. Moreover, al-Rāzì believes that this is found in revelation. The prime example is when God obligated the Prophet's uncle Abū Lahab to believe while knowing and revealing that he would not do so. Since God's foreknowledge could not have been contradicted lest $\mathrm{He}$ become ignorant, it was inherently impossible that Abū Lahab believe. Additionally, obligation of anything apart from God's knowledge of what will happen is obligation of what one is not able to do. ${ }^{132}$

Ibn Taymiyya evades al-Rāzì̀s conclusions by switching from the eternal divine perspective adopted by al-Rāzîs argument to the human historical perspective, and from the necessitating divine knowledge to the secondary causal sense of human power. Ibn Taymiyya explains that God commanded Abū Lahab to believe and that God did not put Abū Lahab in the predicament of having also to believe that he would not believe. God did not tell the Prophet to share the quranic verse, "[Abū Lahab] will burn in a fire of blazing flames" (Q. 111:3), with Abū Lahab himself. The shaykh also cites the parallel example of Noah and his people. God told Noah that no more

${ }^{129}$ For a detailed discussion of al-Ash'arîs views on this, see Gimaret, La doctrine d'alAsh' arī, 437-9.

${ }_{130} \mathrm{Jabr}, 8: 469-470 ;$ Dar $^{3}, 1: 60-3$; and Minhäj, 3:52-3/1:276, 3:102-7/2:15-6. There is also considerable discussion of taklîf mà lā yuțāq in $S a^{\prime} \bar{a} d a$, MF 8:293-302, and numerous scholars are linked to the various positions identified. However, I have not relied on this text because its structure is confused and may be corrupt. This should entail no loss since its basic ideas are found in the other texts employed.

${ }_{131} \mathrm{Jabr}$, MF 8:471-4, 498-500; Minhāj, 3:107/2:16; Sáāda, MF 8:302; Tä́ $a$, MF 8:437-8; and Dar', 1:62-4. See Gimaret, Théories de l'acte humain en théologie musulmane, 151-2, and Yasin Ceylan, Theology and Tafsir in the Major Works of Fakhr al-Din al-Räzì (Kuala Lumpur: International Institute of Islamic Thought and Civilization, 1996), 159-161, for discussions of Rāzìs doctrine of taklîf mà là yuțàq.

${ }^{132}$ See also $T \tilde{a}^{-r} a$, MF 8:438ff. 
of his people would believe (cf. Q. 11:36), but God did not tell Noah to convey this message to his people.

Furthermore, Ibn Taymiyya argues, human disobedience occurs for lack of human will, not for lack of power, and not because God knew it would occur. ${ }^{133} \mathrm{~A}$ discussion of impossibility (al-mumtani ${ }^{C}$ ) later in Jabr clarifies the shaykh's point. He says that it is correct that what is contrary to God's foreknowledge will not happen and that if it did happen it would turn God's knowledge to ignorance. However, this does not mean that someone obligated to do what God knows will not happen is unable to carry out the respective obligation. It could be that the one obligated is able but has no will to do it. "Then," the shaykh concludes, "he is obligated to do only what he is able to do despite the knowledge of the Lord that it will not be."134

Ibn Taymiyya advances his argument further by invoking a parallel with the operation of God's will. God knows that what He does not will will not exist. However, this does not mean that God could not will it. What He knows will not exist is only impossible by virtue of His not willing it, not because it is inherently impossible or because $\mathrm{He}$ is unable to do it. The shaykh supports this with a number of quranic verses including, "If your Lord had willed, He would have made you one nation" (Q. 5:48). Likewise, then, humans may be able to do something but not will to do it. ${ }^{135}$

This bit of polemic works for Ibn Taymiyya only because he has diverted the reader's attention from the perspective of God's fixed foreknowledge to that of temporality and history, in respect both of human power and God's will. Possibly it would be fairer for him to argue that the human act is contingent from the perspective of human power and necessary from that of God's knowledge. However, to conclude from this that humans are obligated beyond what they are able to do would not fit his interpretation of the Qur'an and would probably offend his sense of what befits God's perfection.

\section{No Speaking of Compulsion (jabr)}

In a number of texts, Ibn Taymiyya devotes attention to the term compulsion (jabr), which Jahm b. Șafwān and al-Rāzì employ to describe the

\footnotetext{
$133 \mathrm{Jabr}, \mathrm{MF} 8: 471-4$.

$134 \mathrm{Jabr}, \mathrm{MF} 8: 498-9$.

$135 \mathrm{Jabr}, \mathrm{MF}$ 8:498-500. In Dar', 1:62, the shaykh also observes that those who deny God's power to do anything but what He knows share a fundamental presupposition with the extremist Qadarīs who deny God's foreknowledge: "Both sects agree that the opposite of what is known is not possible (mumkin) or within the realm of possibility (maqdür 'alayhi)."
} 
human act. In $D a r^{3}$ the shaykh draws directly from a discussion of the early Jabrī/Qadarī controversy in Abū Bakr al-Khallāl's al-Sunna, which appears no longer to be extant. ${ }^{136}$ Following al-Khallāl, Ibn Taymiyya reports that the early hadith specialist al-Zubaydī (d. 149/766) completely denies that God compels. This is because the generally accepted meaning of the term is coercing (ilzam) someone against his good pleasure (rid̄a $)$, as when jurists say that a woman is compelled to be married apart from her choice and good pleasure. The shaykh explains that God does not compel someone in this sense because God has the power to make someone choose and be well pleased to do what he does and to make someone hate what he does not do. Someone who chooses his acts is not compelled. ${ }^{137}$

Ibn Taymiyya reports a second view, that of the early jurist al-Awzầ (d. 157/774), who prohibits speaking about compulsion since the term does not appear in the Qur'an and the Sunna. ${ }^{138}$ The shaykh explains that al-Awzầi 1 s prohibition against discussing the term compulsion is better than al-Zubaydî's complete denial. The reason relates to the fact that one of God's names, which does appear in the Qur'an, is "Compeller (al-Jabbär)" (Q. 59:23), a name with the same Arabic root as compulsion. In this regard, Ibn Taymiyya notes that a certain Muhammad b. Ka ${ }^{\mathrm{b}} \mathrm{b}(\mathrm{d} .118 / 736)^{139}$ said, "[God] is only called Compeller because He compels creatures to [do] what He wills." The shaykh takes this to be a correct usage of compulsion. Thus, al-Zubaydîs position may deny something that is true in the process

136 Dar', 1:65-72. Minhāj, 3:36/1:271, 3:245-8/2:51; Irāda, MF 8:131-2; Kasb, MF 8:395; Sáāda, MF 8:294; Jabr, MF 8:361-2; A'lā, MF 16:141-2; and Shams, MF 16:237 contain similar but briefer and less precise discussions. See H. Laoust, "al-Khallāl," EI2 4:989-990, for a discussion of al-Khalläl's works.

137 Dar' $^{\prime}, 1: 66-7$.

138 Dar', 1:66-7. Still drawing on al-Khallāl, Ibn Taymiyya notes that Sufyān al-Thawrī also denies compulsion and says that God "naturally disposes ( jabala)" people. In response, the hadith specialist Abū Bakr al-Marwazì (d. 292/905) supposes that al-Thawrī had in mind the following hadith: "[The Prophet said to Ashajj 'Abd al-Qays], 'In you are two characteristics that God loves: gentleness and deliberateness.' He said, 'Two characteristics that I have affected or two characteristics to which I have been naturally disposed ( jubiltu)?' [The Prophet said], 'Of course, two characteristics to which you have been naturally disposed.' He said, 'Praise be to God who has naturally disposed me with two characteristics God loves.' This is as quoted in $D_{a r}$ ', 1:68, where it is traced to the collection of Muslim. However, very little of this hadith appears in Muslim (see e.g. Muslim, 24, 25, Al-Īmān, Al-Amr bi-l-īmān bi-Allāh, ta'ālā...). Closer, but not exact, versions appear in Abū Dāwūd, 4548, Al-Adab, Fī qublat al-rijl; and Aḥmad, 17160, Musnad al-shāmiyyīn, Hadīth wafd 'Abd al-Qays 'an al-Nabī. Ibn Taymiyya often quotes this hadith, as in Minhäj, 3:247/2:51; Jabr, MF 8:462; and $A^{\prime} l \bar{a}$, MF 16:142.

${ }^{139}$ In Kasb, MF 8:395, Ibn Taymiyya says that Muhammad b. Ka'b was among the most excellent of the second generation in Medina. 
of denying what is false, whereas the position of al-Awza- $a^{-} \bar{i}$ does not run this risk. ${ }^{140}$ In Minhāj, Ibn Taymiyya also attributes al-Awzā̄î̀s position to Sufyān al-Thawrī (d. 161/778) and Ahmad b. Hanbal. ${ }^{141}$

In Jabr Ibn Taymiyya elaborates his views more extensively. He explains that in ordinary language contexts the term compulsion means coercion (ikräh) of others against their wills. He notes, "It is said, 'The father compelled his daughter to marry, and the judge compelled the man to sell what he had to pay his debt." ${ }^{142}$ The shaykh also distinguishes right coercion from wrong coercion. Coercion is justified to make a warring unbeliever accept Islam or pay the jizya, to return an apostate to Islam and to make Muslims perform their religious duties, pay their debts as they are able, and so on. However, it is wrong to coerce someone to disbelieve or disobey as in rape and coercing someone to drink. ${ }^{143}$ Whether right or wrong, "Servants commit this compulsion, which is coercion, with each other because they cannot originate will and free choice in [each others'] hearts or make them commit their acts." ${ }^{144}$ Humans cannot compel others to will, love and hate. The most they can do to get others to follow their wills is arouse desire or strike terror. Coercion consists in terrorizing someone else to the point that the other commits an act he would not otherwise will and choose. Apart from cases in which the one coerced has no power to resist- the shaykh gives rape as an example-the victim does in fact will and choose to commit the act. However, he wills his act only secondarily. His primary intention is to avoid the greater evil that might befall him for noncompliance. ${ }^{145}$

In contrast to human compulsion, which is necessarily coercive, Ibn Taymiyya asserts in Jabr that God's compulsion is not coercive, because He has the power to create the will and the free choice by which humans commit their acts. God makes humans will and love what they do. He can even make humans will something that they hate: "He is able to make [the servant] do something despite his hatred of it. He wills it to the point that he does it despite his loathing of it. For example, an ill person may drink medicine despite his hatred of it." ${ }^{\prime 46}$ The shaykh adds that God moreover creates this hatred (karāha). He illustrates this with two quranic verses, "To

\footnotetext{
140 Dar', 1:69.

141 Minhāj, 3:242/2:51.

${ }_{142} \mathrm{Jabr}, \mathrm{MF}$ 8:462-3.

$143 \mathrm{Jabr}, \mathrm{MF} 8: 464,502-4$.

$144 \mathrm{Jabr}, \mathrm{MF}$ 8:463-4.

$145 \mathrm{Jabr}, \mathrm{MF}$ 8:501-2.

$146 \mathrm{Jabr}, \mathrm{MF}$ 8:464.
} 
God prostrates whosoever is in the heavens and the earth obediently or with hatred (karhan)" (Q. 13:15), and, "To Him has submitted whosoever is in the heavens and the earth obediently or with hatred" (Q. 3:83). ${ }^{147}$ Speaking of God's name "Compeller," Ibn Taymiyya explains that it is "from His compulsion, His subjugation and His power that He makes servants willing to do what $\mathrm{He}$ wills from them." ${ }^{148} \mathrm{He}$ also clarifies that all that God does is wise and just, while the compulsion that creatures commit may be unjust, ignorant and foolish. ${ }^{149}$

Despite denying coercion on the part of God in the above discussion, Ibn Taymiyya adds confusion in Jabr by also attributing right coercion to God when he asserts, "God-Exalted is $\mathrm{He}-$ does not coerce anyone except in truth." 150 This inconsistency aside, the shaykh's primary concern is to underline that God's compulsion, if the term be permitted, consists in creating human free choice and will directly with wise purpose in a way that is impossible for humans to create in each other. Even with this clarification, Ibn Taymiyya is reticent to use the word. In Kasb, for example, he argues against direct divine compulsion of human acts on the basis of an intuitive difference between involuntary and voluntary acts. There is a rational and intuitive difference between the shivering of the feverish on the one hand and sitting, praying or stealing on the other. In the latter case, human beings are willing, choosing and able to commit their acts while in the former they are not. Ibn Taymiyya maintains that it is still God who creates the human will that necessitates human acts, and he admits that this is "compulsion by means of will ( jabr bi-tawassut al-iräda)." ${ }^{151}$ Yet, he will not break with tradition and call himself a Jabrī as did al-Rāzì who holds essentially the same view. He argues that it is better not to speak of compulsion lest it be confused with that which humans impose on each other. ${ }^{152}$ As with purpose (gharad) and passionate love ('ishq), which were discussed in Chapter Two above, it is a matter of the ordinary language meaning of compulsion suffering too many negative connotations for use in theological discourse.

\footnotetext{
$147 \mathrm{Jabr}, \mathrm{MF} 8: 464$.

$48 \mathrm{Jabr}, \mathrm{MF} 8: 465$.

$149 \mathrm{Jabr}, \mathrm{MF} 8: 465$.

$150 \mathrm{Jabr}, \mathrm{MF} 8: 505$.

151 Kasb, MF 8:394.

152 Kasb, MF 8:395.
} 


\section{Ibn Taymiyya's Compatibilism as the Golden Mean (wasat)}

It remains to note that what I have been calling Ibn Taymiyya's compatibilism-his conviction that God's all-encompassing power is compatible with real human will and action-is perhaps better expressed in his own quranic idiom as the golden mean (wasat), the balanced intermediate position that avoids extremes (cf. Q. 2:143). In a number of places, the shaykh explains that the People of the Sunna (abl al-sunna) stand in an intermediate position between the various Muslim sects and diverse religions on numerous religious issues. ${ }^{153}$ For example, on the question of God's attributes they take the golden mean between stripping God of His attributes $\left(t a^{c} t i \bar{l}\right)$ and assimilating God to creatures (tashbih), and on the issue of the Companions of the Prophet they take the middle course between the Shilis and the Khārijīs. Among other things, Ibn Taymiyya charges Shî̄is with preferring 'Alī over the first two Sunnī caliphs Abū Bakr and 'Umar, and he accuses the Khārijīs of calling the third Sunnī caliph 'Uthmān an unbeliever and rejecting 'Alī's caliphate. ${ }^{154}$

With respect to God's creation of human acts, Ibn Taymiyya states tersely in Wasitiyya, "[The People of the Sunna and the Community follow] a golden mean concerning the subject of God's acts-Exalted is $\mathrm{He}$-between the Qadarīs and the Jabrīs." ${ }^{155} \mathrm{He}$ outlines his view more fully in another text translated below. Although there is nothing substantially new here, this passage does show Ibn Taymiyya employing the notion found in Ibn Sīnā, al-Rāzì and others that God necessitates or compels the human being to choose freely more clearly than we have seen above. However, he uses the quranic terms 'make' ( $j a$ ' ala) and 'create' in lieu of the linguistically unredeemable 'compel'.

Concerning the subject of [God's] creation and His command, [the People of the Sunna follow] a golden mean between those who belie the power of God, who do not believe in His perfect power, His all-inclusive will and His creation of everything, and between those who corrupt the religion of God, who take the servant not to have a will, a power or a deed. They strip away the command and the prohibition, the reward and the punishment, and they become equivalent to those associationists who said, "If God had willed, we

153 Minhāj, 3:468-9/2:105; Minhāj, 5:168-172/3:42-43; Jawāb, 1:69-75; Wäsitịyya, MF 3:141; Qubrusiyya, MF 28: 613-615; and Wasiyya kubrä, MF 3:369-375, which is translated in Yahya Michot, "Pages spirituelles d'Ibn Taymiyya: II. La religion du milieu," Action (Mauritius) (December 1999), 22-23, 30. See also Laoust, Essai, 220-225.

154 Wasiyya kubrä, MF 3:373, 375.

155 Wàsitityya, MF 3:141. 
would not have given associates, nor would have our fathers, and we would not have forbidden anything [against His will]" (Q. 6:148).

The People of the Sunna believe that God is powerful over everything- $\mathrm{He}$ is thus able to guide servants and turn their hearts-that what God wills is and what He does not will is not-There is nothing in His sovereignty that $\mathrm{He}$ does not will, and $\mathrm{He}$ is not incapable of executing His will-and that $\mathrm{He}$ is Creator of everything with respect to concrete entities, attributes and movements.

And they believe that the servant has a power, a will and a deed and that he is freely choosing (mukhtār). They do not call him compelled (majbür), given that one who is compelled is coerced [to act] differently from his free choice. God-Glory be to Him-made ( ja'ala) the servant someone who freely chooses what he does. He is thus someone who freely chooses and wills. God is his Creator and the Creator of his choice. ${ }^{156}$

\section{Conclusion}

This chapter has shown that Ibn Taymiyya uses several different terms to set out a view of God's creation of human agency that is essentially that of Fakhr al-Dīn al-Rāzì in its metaphysical structure and that has its roots in the causal language of philosophers like Ibn Sinnā. Ibn Taymiyya speaks of the complete necessitating cause with which God creates all human acts directly using terms such as origination, preponderance, decisive human will, complete human power and potency, determining power, and conjoined capability. In order to provide a basis for human accountability to God's command, the shaykh identifies an anterior and legislative power that denotes the bodily soundness of the human agent for undertaking acts. Ibn Taymiyya also discusses the created world and human agency in terms of secondary causes, which are the instruments and raw materials with which God creates, and which, from the human perspective, form a world of natural cause and effect. Among the secondary causes that are relevant to human voluntary action, and which God uses to originate human acts, are human power and will, as well as God's command.

Ibn Taymiyya insists on the compatibility of God's creation of human acts alongside real human agency and responsibility, and, unlike al-Rāzì in his Tafsir, the shaykh does not acknowledge rational difficulty in upholding the two simultaneously. He maintains that human agency is real insofar as it is

156 Wașiyya kubrā, MF 3:373-4. 
something that God creates, but he does not affirm human freedom in the libertarian sense. The shaykh argues that God is just to reward and punish deeds that $\mathrm{He}$ creates because $\mathrm{He}$ creates them in a substrate that is separate from Himself, that is, in the human being. By virtue of this substrate principle, God is not qualified with the human acts that he creates just as he is not qualified with their attributes, such as blackness or tallness.

Ibn Taymiyya's view of God's creation of human agency may be compared to a marionette show in which God is wisely directing the performance in all its detail in order to tell a good story. God cannot be charged with injustice in creating this or that misdeed of a particular marionette because it is necessary to the wise purpose of forwarding the narrative plot. The marionettes perceive themselves to be free agents involved in a drama of obedience and disobedience to the divine command that God has interjected into the story, but God is Author and Creator of the drama as a whole. This gives full scope to God's power, will and wise purpose, while also affirming the reality of human choice and activity.

When faced directly with the contradiction between God the determiner of human acts and human free choice and responsibility, Ibn Taymiyya sometimes switches from God's perspective to the human. This occurs in his use of the image of an author writing with a pen to illustrate how God creates acts in the human. When faced with the absurdity of pens being punished for what they write, the shaykh evades the problem by dropping the pen image and asserting that human beings do have a will and are agents in reality. He then appeals to intuitive knowledge of the difference between voluntary and involuntary acts to complete his switch to the plane of human rationality. Something similar happens when Ibn Taymiyya broaches Fakhr al-Dīn al-Rāzî̀s claim that Abū Lahab could never have believed because God's eternal foreknowledge made his belief impossible. Without notice, the shaykh shifts from God's perspective from which this claim is made to the historical human perspective and explains that Abū Lahab was never put in the predicament of having to believe the revelation of God's foreknowledge that he would not believe.

Ibn Taymiyya does admit that his theology involves divine compulsion ( jabr) of human acts by the intermediaries of human will and power. Al-Rāzī holds essentially the same view, but, unlike al-Ràzī, the shaykh does not allow this position to be called 'compulsion' lest it be confused with direct divine compulsion and evoke negative connotations concerning God. This, along with his insistence on human responsibility and his unannounced perspective switching to avoid mentioning contradiction in God's economy, reflects his 
concern to speak of God according to the highest similitude. Open admission of contradiction would detract from God's perfection and praiseworthiness, and it would open the door to the Iblīsī style irrationality and ethical laxity that he seeks to stem. Rather, Ibn Taymiyya portrays his compatibilism positively as the golden mean between the extremes of the Jabris and the Qadarīs, between hard determinism and libertarian freedom. 
CHAPTER FIVE

\section{THE WISE PURPOSE AND ORIGIN OF EVIL}

\section{Ibn Taymiyya and the Explanation of Evil in Islamic Theodicies}

The question of evil (sharr) in Ibn Taymiyya's writings has not received serious study. Before examining the pertinent texts, it will prove useful to fill in some background on how the preceding Islamic tradition explains evil. A common theme is the educational and disciplinary role of evil in advancing the religious life. Already noted in the Introduction were al-Māturìdìs view that evil is a tool of God's wisdom to lead humankind to knowledge of God's existence and the Sufi notion that evil and suffering are instruments of God's discipline on the spiritual path. Similar ideas are found in the free-will theodicy of the Mu'tazilī 'Abd al-Jabbār who maintains that God inflicts pain not only as punishment for sins but also for the purposes of testing, warning and deterring. ${ }^{1}$

In the best-of-all-possible-worlds theodicy of Ibn Sīnā, all things are good from the vantage point of the whole. Pure or absolute evil does not exist, but relative or partial evil does and is inherent in the perfection of the created order. In the section on providence in al-Shifä, Ibn Sinnā explains that evil, which he understands metaphysically as imperfection (naqs) and 'adam-a term that I will translate variously as "nonexistence," "privation" or "lack" —is necessary to some things for them to be what they are. By way of example, he argues that burning is necessary to the perfection of fire even if fire occasionally burns someone. If such things did not involve evil, they would in fact be something else, but they must exist as they are for the maintenance of the universal order. In addition to the nonexistence of absolute evil and the necessity of relative evil to the perfection of things, Ibn Sinna also speaks quantitatively about evil. He affirms that the amount of evil in the universe is very small compared to the great amount of good. ${ }^{2}$

\footnotetext{
${ }^{1}$ Heemskerk, Suffering in Mu'tazilite Theology, 151-6.

2 Ibn Sīnā, Al-Shifä: Al-Ilāhiyyāt (2), 414-422. Ibn Sīnā, "Al-Risāla al-'arshiyya," 16, also attributes wise purpose ( ikma) to evils. For further analysis of metaphysical evil in the thought of Ibn Sīnā, see Abū Zayd, Mafhüm al-khayr, 112-118, 152-159; and Inati, The Problem of Evil, 65-101. 
Other parts of the Islamic tradition elaborate further answers as to why evil is necessary for the best possible order. In Ihyyà 'ulüm al-dìn, al-Ghazāli roots the necessity of evil in the principle that things cannot be known except by their opposites. Health is not enjoyed without illness; the blessed in Paradise would not know their blessedness without Hell; and perfection is not known without imperfection. ${ }^{3}$ Ibn 'Arabī employs an additional explanation for evil, what Arthur Lovejoy in his classic The Great Chain of Being calls the "principle of plenitude," which locates the good in the greatest possible variety. ${ }^{4}$ For Ibn 'Arabī, God bestows existence on the cosmos for the great good of making Himself known. Evil and imperfection, which are paradoxically no more than privation and otherness from the sole reality of God and yet real in that they thwart God's Law and human purposes, are necessary in order to afford God the possibility to manifest the infinite diversity, the great plenitude, of His names. Everything in existence reflects a divine name such as All-Merciful, Giver of Life, Giver of Death, Honorer, Humiliator and so forth. These names extend in number beyond the traditional ninety-nine to infinity. Nonetheless, Ibn 'Arabī maintains that, out of courtesy for God, we should address God only with names that He has revealed. We should not, for example, call God Liar or Ignorant. ${ }^{5}$

The principle of plenitude and the idea that things are known only by their opposites do not appear explicitly in Ibn Taymiyya's thought on evil, but he does speak of evil's educational qualities, its logical necessity in the nature of the world, its relativity and its quantitative insignificance. However, congruent with his juridical concern to speak well of God, the shaykh's primary interest is finding ways not to attribute evil to God even though it is God who is ultimately responsible for the world being the way it is. In the end his refuge is God's wise purpose.

The first section below examines Ibn Taymiyya's three-fold typology for attributing evil. This includes discussion of his views on God's names. The second section investigates the degree to which he believes that God's wise

${ }^{3}$ Al-Ghazālī, Ihyyà 'ulüm al-dìn, 4:258-9 (at the end of "Kitāb al-tawhìd wa al-tawakkul"). Ormsby, Theodicy, 40 and 64-9, provides a translation and analysis of this text. The idea that things are known through their opposites is also found in al-Halläj and others, especially in reflection on the fate of Ibliss. On this, see Awn, Satan's Tragedy and Redemption, 122-150.

${ }^{4}$ Arthur O. Lovejoy, The Great Chain of Being: A Study of the History of an Idea (Cambridge, MA: Harvard University Press, 1936), 52ff.

5 Chittick, The Sufi Path of Knowledge, 33-44, 289-297. For briefer treatment of these themes, see William C. Chittick, Imaginal Worlds: Ibn al-'Arabi and the Problem of Religious Diversity (Albany, NY: State University of New York Press, 1994), especially Chapters 2, 3 and 8 . 
purposes may be known and his few suggestions as to what they are. The third section shows how Ibn Taymiyya employs the metaphysical concept of evil as nonexistence for moral and religious ends in Hasana and Fätiba.

\section{Ibn Taymiyya's Evil Attribution Typology}

\section{Attributing Evil to the Generality, the Secondary Cause or the Elided Agent}

In Minhāj, Iräda, Kasb, Jabr, Hasana and a few other texts Ibn Taymiyya asserts that evil must not be attributed directly to God but rather in one of three other ways, which he presents in a recurring typological form. ${ }^{6}$ This three-fold typology appears in diverse contexts with varying degrees of fullness. Occasionally, it appears as a hermeneutic grid comprehending the ways that evil is attributed in the Qur'an or in both the Qur'an and the Sunna. Most often, however, the shaykh cites it as a general statement of how evil is attributed. In the first type evil "falls within the compass of the generality ('umüm) of created things," or "falls within the compass of the generality," or, more tersely, is attributed "by way of the generality." In the second type, evil is attributed to its secondary cause (sabab), its agent cause (al-sabab al$\left.f_{\bar{a}} \bar{i} i\right)$ or the creature (makblüq). In the third type, evil is mentioned without reference to its agent.

\section{The Attribution of Evil in the Qur'an}

Although Ibn Taymiyya gives very little direct explanation of the three types in the evil attribution typology itself, he usually supplies examples of each from the Qur'an. As an example of the first type in which evil is attributed to the "generality," the shaykh customarily cites, "God is the Creator of everything" (Q. 13:16, 39:62), or, "He has created everything" (Q. 25:2). These verses do not explain what it means for evil to fall "within the compass of the generality" except to direct attention away from God's creation of evil specifically and to His creation of all things in general. More will be said about the interpretation of this type below. The attribution of evil to its

\footnotetext{
${ }^{6}$ Iräda, MF 8:93-7; Kasb, MF 8:400-1; Täa a, MF 8:446-7; Jabr, MF 8:511-2; Fätiha, MF 14:21; Hasana, MF 14:265-6; Thulth, MF 17:94-6, 99; and Minhäj, 3:142-5/2:25-6, 5:408-411/3:102.

7 In the Qur'an in $T \bar{a}^{-} a$, MF 8:447, and in both the Qur'an and the Sunna in Iräda, MF 8:94; and Jabr, 8:511.
} 
secondary cause, that is, the creature, is more obvious, and, as an example, Ibn Taymiyya often cites, "Say, 'I seek refuge with the Lord of the daybreak from the evil of what He has created" (Q. 113:1-2), that is, from the evil instigated by God's creatures. The shaykh's standard example of the third type is the quranic statement about the jinn: "We do not know whether evil is willed for those in the earth or whether their Lord wills rectitude for them" (Q. 72:10). Here, the agent willing evil, presumably God, has been elided and the verb "to will" put in the passive voice.

In the two instances of the typology in Minhäj, Ibn Taymiyya observes that all three types are found in the first chapter of the Qur'an: "Guide us in the Straight Path, the path of those whom You have blessed, not those upon whom is anger, and not those who went astray" (Q. 1:6-7). ${ }^{8}$ In these verses, God is the agent $\left(f_{\bar{a}}^{-c} i l\right)$ of blessing (first type). The agent of anger has been elided (third type), and the evil of going astray is attributed to creatures themselves (second type). The shaykh also gives this illustration in Jabr, but he presents the earlier verse, "Praise be to God, Lord of the worlds" (Q. 1:2), as the example of the first type." Ibn Taymiyya provides no additional quranic examples of the first and third types. Moreover, the third type receives no further discussion at all. Elision of the agent of evil is no more than a rhetorical device or form of courtesy that the shaykh finds the Qur'an using to avoid attributing evil to God.

In Iräda the shaykh gives several more quranic examples of attributing evil to human secondary causes: "Our Lord, we have wronged ourselves" (Q. 7:23); "When an affliction comes to you, even after having dealt one out twice as great, you say, 'From where does this come?' Say, 'It is from yourselves'" (Q. 3:165); and "Any good thing that comes to you is from God, and any evil thing that comes to you is from yourself" (Q. 4:79). ${ }^{10}$ Elsewhere, he adds Abraham's attribution of illness to himself but the cure to God: "And when I am ill, He cures me" (Q. 26:80). ${ }^{11}$ Ibn Taymiyya also illustrates the attribution of evil to its secondary cause with brief quotations

\footnotetext{
${ }^{8}$ Minhäj, 3:143/2:25 and 5:410/3:102. English translations of ghayr al-maghdüb 'alayhim as "not (the way) of those who have earned Your Anger" (Hilālī and Khān), "not of those against whom Thou art wrathful" (Arberry) or "Not (the path) of those who earn Thine anger" (Pickthall) do not accurately translate the Arabic by obscuring the fact that no agent of anger is mentioned in the text.

$9 \mathrm{Jabr}$, MF 8:511. Ibn Taymiyya also mentions in Hasana, MF 14:272, that the threefold evil attribution typology is found in the first chapter of the Qur'an, but he does not explain beyond the first type.

${ }_{10}$ Iräda, MF 8:95.

${ }_{11} \mathrm{Jabr}$, MF 8:511; Kasb, MF 8:401; and Minhäj, 3:143/2:25, 5:410/3:102.
} 
from the quranic story of the guide who led Moses through three ordeals (Q. 18:60-82). ${ }^{12}$ When explaining the reasons for his puzzling actions, the guide, whom Ibn Taymiyya takes to be the mythical Khidrr, attributes his prima facie evil acts of sinking a boat and killing a boy to himself but attributes his good act of straightening a leaning wall to God. These verses concerning Abraham and Khiḍr show not only that evil is attributed to creatures but also that good comes from God. The human agent gets sick, sinks a boat and kills, but God rights a leaning wall and cures the sick.

\section{Evil Is Good in God's Wise Purpose, and Good Far Exceeds Evil}

As mentioned above, Ibn Taymiyya does not clearly specify what he means in the first type of the evil attribution typology by evil falling "within the compass of the generality of created things." ${ }^{13}$ However, the contexts of these typologies elaborate this in three different ways that echo Ibn Sinnā. First, from God's perspective, the generality of what God creates is wholly good; evil is relative and exists only from the perspective of creatures. Second, evil is a necessary concomitant of the perfection of the created order. Third, from the human perspective, the generality of good is far greater in quantity than evil.

In the first of these three ways, Ibn Taymiyya maintains that what creatures regard as evil is good by virtue of God's wise purpose. The following from Minhäj is typical: "If God-Exalted is $\mathrm{He}$-is Creator of everything, He creates good (khayr) and evil (sharr) on account of the wise purpose that He has in that by virtue of which His act is good (basan) and perfect (mutqin)."14 A nearby passage extends this to more unseemly things: "God is Creator of illnesses, aches, hateful odors, ugly forms and noxious bodies like snakes and human excrement on account of a profound wise purpose in them." ${ }^{15}$ In Hasana, the shaykh underscores that what makes all God's

$12 \mathrm{Jabr}, \mathrm{MF}$ 8:512; and Iräda, MF 8:95.

13 Irāda, MF 8:94.

${ }_{14}$ Minhāj, 3:142/2:25.

${ }_{15}$ Minhāj, 3:144/2:25. Ibn Taymiyya, Minhäj, 3:144-5/2:25, clarifies that these things, as with everything else that God creates, come neither from God's essence nor from His command. In the same passage the shaykh tersely explains that everything that God creates is good "according to the two doctrines of 'delegation' and 'causality' ('alà qawlay al-tafwìd wa al-ta'lill)." I understand this to mean that God's creation of evil is not evil on His part because of His delegation of it to a creature or secondary cause and by virtue of the final causality in His will, that is, His wise purpose in creating it. 
deeds good is wise purpose while what makes human evil deeds evil is a lack of wise purpose. ${ }^{16}$

Ibn Taymiyya grounds the doctrine of God's wise purpose in quranic texts showing that all God's creative acts are good and true. Most commonly, he cites, "The handiwork of God who perfected everything" (Q. 27:88), and, "Who made good everything He created" (Q. 32:7). ${ }^{17}$ In Fätiha he adds, "We did not create the heavens and the earth and what is between them except with truth" (Q. 15:85), and, "[Those who] reflect on the creation of the heavens and the earth, [saying], 'Our Lord! You have not created this in vain"” (Q. 3:191). ${ }^{18}$ These last two verses and several others denying aimlessness and vanity in God's creative work are given in Thulth, a commentary on Surat al-Ikhlās (Q. 112) that will be discussed at greater length below. ${ }^{19}$ In several places, the shaykh also quotes the hadith, "Good is in Your hands, and evil is not [attributed] to You," to affirm the goodness of all that God does. ${ }^{20}$

In view of the complete goodness of the evil that God creates, Ibn Taymiyya notes in the contexts of the evil attribution typology in Iräda, Jabr, Hasana and Fätiha that God does not create evil that is absolute (mutlaq), general ('ämm), total (kullī) or pure (mahd). Rather, the evil that God cre-

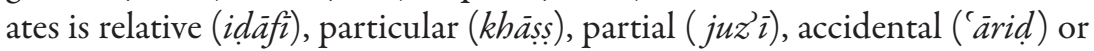
restricted (muqayyad). ${ }^{21}$ Evil is thus evil relative only to those who commit it or suffer its harm. The following passage from Hasana gives concise expres-

16 The text in Hasana, MF 14:275, reads: "[God] created [an evil deed] only for a wise purpose. It is not attributed to Him in respect to its being an evil deed (sayyi a). Rather, it is attributed to the person (nafs) who commits evil (sharr) by it without wise purpose. She deserves to have evil and an evil thing attributed to her. In what she commits of sins, she does not aim at a good on behalf of which committing it is preponderant. On the contrary what is like this is in the category of good things. Therefore, the act of God is good ( hasan). He never does a bad thing (qabì ) or an evil deed."

${ }_{17}$ Minhāj, 3:142/2:25, 5:409/3:102; Irāda, MF 8:94; Jabr, MF 8:512; and Fätiha, MF 14:21.

${ }^{18}$ Fätiha, MF 14:21.

19 Thulth, MF 17:95-6, 99. The additional references are Q. 6:73, 15:85-6, 21:16-7, 23:115, 38:27, 44:39 and 75:36.

${ }^{20}$ Kasb, MF 8:400; Jabr, MF 8:511; Fätiha, MF 14:18; Hasana, MF 14:266; Thulth, MF 17:94; and Minhāj, 5:409/3:102. The hadith is found in Muslim, 1290, Șalāt al-musāfirīn wa qașruhā, Al-Du'ā' fị șalāt al-layl wa qiyāmihi. Ibn Taymiyya, Minhāaj 5:409/3:102, notes that the latter part of this saying, wa al-sharr laysa ilayk, is subject to more than one interpretation. It has been understood to mean either that one cannot draw close to God with evil deeds or that evil is not attributed to God. In Thulth, MF 17:94, he also adds the possibility that it means "evil is nonexistence ('adam) or among the concomitants of nonexistence." The shaykh does not rule out any of these interpretations, but I have chosen to translate the saying as denying evil's attribution to God because that befits the context.

21 Iräda, MF 8:94; Jabr, MF 8:512; Hasana, MF 14:266, 270; and Fätiba, MF 14:20-1. 
sion to these ideas using several of the aforementioned terms: "[God] does not create pure evil. Rather, in everything that $\mathrm{He}$ creates is a wise purpose by virtue of which it is good. However, there may be some evil in it for some people, and this is partial, relative evil. As for total evil or absolute evil, the Lord is exonerated of that."22

In Fatiha the shaykh employs the relativity of evil to interpret exhortations to believe in both the good and evil of God's determination. He relates, for example, a hadith transmitted by Abū Dāwūd, "If you had disbursed [in alms] a whole earth full of gold, [God] would not have accepted it from you until you had believed in determination, its good and its evil." ${ }^{\prime 23} \mathrm{Ibn}$ Taymiyya explains that the evil mentioned here is only evil for the person who suffers pain under it and that what is evil for one may in fact be a blessing for another: "When evil afflicts the servant, the heart of his enemy is glad. It is good for the one and evil for the other. There is no good and no evil with respect to one who has no friend and no enemy."24 In this view, evil is associated with pain and disadvantage to a particular individual, whereas, from God's perspective, everything is good.

In Hasana Ibn Taymiyya links Aristotelian causal terminology to the first two types in his three-fold evil attribution typology. This further illustrates how he folds evil into God's general and complete goodness: "[Evil] is not attributed simply to God-Exalted is $\mathrm{He}-$ [but it is attributed] in two respects: in respect to its final cause (al-illa al-ghä iyya) and in respect to its secondary cause (sabab) and agent cause (al-illa al-fä́liliyya)."25 Ibn Taymiyya then equates the philosophical term final cause with wise purpose, and he asserts that God does not create pure evil in which there is no wise purpose or mercy. He explains that mentioning evil with respect to God's activity must always be done in the proper context of God's more general wise

${ }^{22}$ Hasana, MF 14:266. Cf. Hasana, MF 14:268. In Jabr, MF 8:512, the shaykh makes the same point: "The created thing is good and wise by virtue of the wise purpose for which it was created even if there is evil in it in another respect. This is something accidental and partial that is not pure evil. Rather, evil through which preponderant good is intended is good coming from the Wise Agent, even if it is evil for the one in whom it subsists." In Fätiha, MF 14:21, Ibn Taymiyya explains: "God did not create anything except for a wise purpose. This wise purpose is its aspect of goodness (busn) and good (khayr). In created things, there is no pure evil in which there is no good and in which there is no advantage in any respect."

${ }^{23}$ Fätiha, MF 14:20. The hadith is found in approximately this form in Abū Dāwūd, 4077, Al-Sunna, Fī al-qadar.

${ }^{24}$ Fätiba, MF 14:21.

${ }^{25}$ Hasana, MF 14:299. Ibn Taymiyya structures a major portion of Hasana around these two causes: MF 14:299-315 is headed by discussion of the final cause, and MF 14:315-331 begins with the agent or secondary cause. However, the text meanders, and the shaykh does not confine himself to direct exposition of these two causes in the course of these pages. 
purpose. For example, he argues that it is wrong merely to say, "Muhammad and his nation spill blood and spread corruption in the earth," because this is subjecting them to blame. Rather, one should say, "They undertake jihad in the way of God in order that the word of God be highest and all religion be for God, and they kill whoever obstructs them from that." ${ }^{26}$ Likewise, it is erroneous to say that God creates evil that is of no profit to anyone. Instead, one should affirm that God in His wisdom has created everything good and that "He has in what He creates of pain or blameworthy deeds in living beings a great wise purpose and a momentous blessing." ${ }^{.7}$ By placing the focus on God's goodness and wise purpose first, any accompanying evil finds its place as evil relative only to particular creatures. Moreover, this relative evil is wholly good by virtue of God's wise purpose.

In a discussion linked to the evil attribution typology in Hasana, Ibn Taymiyya complains that two groups go astray on this issue. The first group, seeking to protect God from doing bad deeds, denies that God wills all things or creates human acts, while the second group asserts that God may create evil without a wise purpose. ${ }^{28}$ Although unnamed, the two groups are obviously the Mu'tazilīs and the Ash'arīs, respectively. Ibn Taymiyya observes that both groups do not adequately distinguish particular evil from general evil or relative evil from absolute evil. They conceive evil solely in an absolute sense that applies equally to creatures and the Creator but fail to grasp that evil is only evil relative to creatures. He gives the case of lying prophets as further evidence that God does not create general evil. In His wise purpose, God may lead some people astray, but His wise purpose precludes confirming lying prophets with miracles because that would show God to be weak and unable to differentiate truth-tellers from liars. For God to support a lying Prophet with the same miracles with which He supports truth-telling prophets would be a general evil. ${ }^{29}$

Ibn Taymiyya's second way of making sense of what it means for evil to fall under the generality of created things is to argue that evil is logically necessary to the perfection of creation. The shaykh does not elaborate on this extensively, but in Jabr he does broach the question why God's wise purpose could not have been achieved apart from any evil whatsoever. He explains that the question reveals a lack of knowledge of the reality and

\footnotetext{
26 Hasana, MF 14:300.

27 Hasana, MF 14:300.

28 Hasana, MF 14:266-7.

29 Hasana, MF 14:268, 270-1.
} 
interconnectedness (irtibāt) of things. Much in the fashion of Ibn Sinnā, Ibn Taymiyya argues that God is bound by logical constraints: "When God creates something, $\mathrm{He}$ must inevitably create its necessary concomitants." ${ }^{30}$ God cannot join two contraries at one time, and He cannot create what is impossible. God cannot, for example, make someone simultaneously a believer and an unbeliever, even if He can join together a measure of belief and hypocrisy in the same person. Ibn Taymiyya adds that God's attributes of knowledge, power, wisdom and mercy are of the utmost in perfection and that such perfection is necessary for the Lord. ${ }^{31}$ The implication is that this world with its relative evil is the best possible in the divine perfection and that evil is necessary to the achievement of God's purpose. Ibn Taymiyya affirms that this is the best possible world explicitly in 'Adil, which will be discussed in Chapter Six.

Ibn Taymiyya's third way of elaborating the sense in which evil is attributed by way of the generality is illustrated in a text from Fätiha. Here, even from the human perspective, evil is minimal in comparison to the great amount of good that God creates:

In the things that God creates there is nothing that always inflicts pain on all creatures, and there is nothing that always inflicts pain on most of them. On the contrary, the things that He creates bless them, or most of them, most of the time, like the sun and health. There is nothing among the existent things which God creates that is evil absolutely [and] generally. It is known that created, existent evil is restricted, particular evil. There is another aspect by which it is good and a good thing and which is the preponderant of the two aspects. $^{32}$

Quantitative analysis of evil on the creaturely plane is also found in Irada, where Ibn Taymiyya opens a discussion of evil by affirming that God has a wise purpose in the generality of what He creates: "The general things that [God] does are for a general wise purpose and general mercy, as, for example, the sending of Muhammad-God bless him and give him peace." ${ }^{33}$ Then the shaykh broaches a peculiar problem of evil involving the Messenger and provides two quantitative responses:

Jabr, MF 8:512.

Jabr, MF 8:512-3.

32 Fätiba, MF 14:21.

${ }^{33}$ Iräda, MF 8:93. Ibn Taymiyya backs this up with several quranic references: "We have not sent you except as a mercy to the worlds" (Q. 21:107) and Q. 3:144, 3:164, 6:53 and $14: 28$. 
When someone says, "A group of people like those from among the associationists and the People of the Book who considered [the Messenger] a liar were harmed by his message," there are two answers to this. ${ }^{34}$

The first of them is that he profited them to the extent possible. He weakened their evil that they were committing. [What would have happened] had it not been for the message with the manifestation of arguments and signs that made what was in their hearts tremor and with jihad and the poll tax that frightened them and humiliated them until their evil decreased? Whomever he killed among them died before his life grew long in unbelief and his unbelief became greater. Thus, this was a reduction of his evil. The messengers-God bless them-were raised up to obtain benefits and perfect them and to strip away detriments and reduce them to the extent possible.

The second answer is that whatever harm occurred is a minuscule thing beside whatever profit occurred. An example is the rain whose profit is general even if some houses are destroyed by it and some travelers and laborers, like the fullers and their like, are held up by it. Something whose profit and benefit is general is an intended good and beloved mercy even if some people are harmed by it. Certain groups of the Muslims, the Kalām theologians, the jurists and others among the Hanafis, the Hanbalīs and others, and among the Karrāmīs and the Sufis give this answer, and it is the answer of many of the philosophers. ${ }^{35}$

In this text, Ibn Taymiyya's first argues that the Prophet reduced evil to the extent possible and even cut short the lives of unbelievers for their own good. The shaykh argues similarly in Hasana that the great good and happiness rendered by Muhammad's message bear no relation to the limited misery and partial evil suffered by the Arab associationists and the unbelieving People of the Book. ${ }^{36}$ The second answer in the above passage explains that the evil incurred by rain is a small price to pay for the much greater good obtained through it. Both answers appeal to the quantitative insignificance of evil on the plane of human affairs.

\section{The Relation of God's Names to Evil}

An illustrative component accompanying several instances of the evil attribution typology is consideration of God's names. Following the pattern of the second type, Ibn Taymiyya sometimes excludes evil from God's names entirely and locates it in created things. The following from Irāda is typical: "There

\footnotetext{
${ }^{34}$ Fakhr al-Dīn al-Rāzī also takes up this question in his Tafsìr, 22:230-1, on Q. 21:107.

35 Iräda, MF 8:93-4. See also Hasana, MF 14:268, for the claims that rain and the sending of a messenger are general goods.

${ }^{36}$ Hasana, MF 14:276-7.
} 
is no name among the most beautiful names of God that entails evil. Evil is only mentioned in the things that He enacts (maf' $\bar{u}$ latibi). ${ }^{37}$ The shaykh supports this with several quranic verses in which the evils of punishment and chastisement are clearly distinguished from God's names: “Tell My servants that I am the Forgiving, the Compassionate and that My chastisement is the painful chastisement" (Q. 15:49-50); "Your Lord is swift in punishment, and He is the Forgiving, the Compassionate" (Q. 6:165); "Know that God is severe in punishment and that God is Forgiving, Compassionate" (Q. 5:98); "Truly, the grip of your Lord is severe. Truly, He it is Who begins and returns, and He is the Forgiving, the Loving" (Q. 85:12-4). ${ }^{38}$ In Thulth Ibn Taymiyya provides additional interpretation: "[God] regarded forgiveness and mercy to be among the meanings of His beautiful names with which He names Himself... As for the punishment that connects to servants, this is a creation of His, and it is this which is painful. He did not say, 'Truly, I am the Chastiser."' ${ }^{39}$

In both Iräda and Thulth, Ibn Taymiyya takes up the name Avenger (alMuntaqim) because it contradicts his claim that God's names involve no mention of evil. Although this name appears in the Qur'an, Ibn Taymiyya explains that it is qualified (muqayyad) by something in the immediate quranic context: "From the criminals We are avenging (muntaqimün)" (Q. 32:22); and "God is All-Mighty, possessor of vengeance (dhü intiqäm)" ( $\mathrm{Q}$. $3: 4) .{ }^{40}$ The shaykh does not clarify what these qualifying elements are, but the reader is left to assume that God's vengeance is limited to "the criminals" in the first example and subsumed under God's name All-Mighty in the second. Ibn Taymiyya also argues that Avenger is not one of the established beautiful names of God and that the hadith in the collection of al-Tirmidh ${ }^{-41}$ listing Avenger as an independent and unqualified name of God does not come from the Prophet himself. ${ }^{42}$

Even though Ibn Taymiyya excludes evil completely from God's names in some passages, he explains in other places that evil is suggested in the

${ }^{37}$ Iräda, MF 8:96. Cf. Täa a, MF 8:447; Thulth, MF 17:94; and Minhāj, 3:143/25:2.

38 Iräda, MF 8:96.

39 Thulth, MF 17:94-5.

${ }^{40}$ Ibn Taymiyya also mentions that Avenger is a qualified name in Hasana, MF 14:276.

${ }^{41}$ Tirmidhī, 3429, Al-Da'awāt 'an rasūl Allāh, Mā jā̀a fī 'aqd al-tasbīh bi-l-yad.

42 Iräda, MF 8:96-7; and Thulth, MF 17:95. Ibn Taymiyya, Iräda MF 8:97, adds that the only other hadith listing the ninety-nine names of God, that of Ibn Māja, 3851, Al-Du'ä', Asmä' Allāh 'azza wa jalla, has a weak chain of transmission. Elsewhere, the shaykh, MF 22:481-6, explains that "ninety-nine" is simply a large number and does not actually indicate the exact number of God's names. In his view, the Qur'an and the Sunna supply more names than those listed in the two hadiths transmitted by Tirmidhī and Ibn Māja. 
mention of some of the names but that these names are then conjoined with other names having positive significance. Ibn Taymiyya usually takes up the conjoined names under the rubric of the first type in the evil attribution typology. An excerpt from Minhajj provides one of the shaykh's fuller explanations of this:

If [God] is mentioned by His particular (khässs) name, it is conjoined with the good, as He says in His most beautiful names: the Harmer/the Profiter (al-Dârr al-Näfí), the Giver/the Impeder (al-Mu'tī al-Mãni $\left.{ }^{\top}\right)$, the Abaser/the Exalter (al-Khäfid al-Räfí), and the Honorer/the Humiliator (al-Mu'izz al-Mudhill). He combines the two names because of the generality and inclusiveness in this, which indicates His unity. ${ }^{43}$

Apparently reticent to implicate the names Harmer, Impeder, Abaser and Humiliator in evil directly, Ibn Taymiyya instead labels them "particular" names. These are then conjoined to Profiter, Giver, Exalter and Honorer, respectively, to mitigate their severity and point to the general and all-inclusive creative work of God. A brief explanation of the conjoined names in Iräda concurs with this interpretation: "Neither the name Impeder is isolated from its conjoint nor Harmer from its conjoint because their conjunction indicates the generality." ${ }^{4}$

There is tension in Ibn Taymiyya's thought on the conjoined names between affirming that God in His various names relates to everything in existence, including evil, and maintaining that all of God's names imply only good. This comes out clearly in accompanying discussions of God's grace and justice in Iräda, Minhāj and Thulth. ${ }^{45}$ Only the fullest treatment, that in Thulth, will be discussed here. Ibn Taymiyya argues in Thulth that one part of God's Word, namely, Surat al-Ikhlās (Q. 112), which is said to be equivalent to one-third of the Qur'an, can be better than another. To support his point, he notes that some of God's attributes are preferable to others, as in the divine saying, "My mercy precedes My anger." ${ }^{46}$ Ibn Taymiyya then extends the principle of preference to God's hands. While there are hadiths which say, "Both of His hands are right [hands],"47 because "left" implies deficiency and there is no deficiency in the hands of God, there is another

\footnotetext{
${ }_{43}$ Minhāj, 5:410/3:102. Three of these pairs of conjoined names are also mentioned in Hasana, MF 14:276.

${ }_{44}$ Iräda, MF 8:95.

45 Iräda, MF 8:95; Minhäj, 5:410-1; and Thulth, 17:91-4.

${ }^{46}$ Bukhārī, 6998, Al-Tawhīid, Qawl Allāh ta ālā bal huwa Qửān majīd fì lawh maḥfūz; Muslim, 4940.

${ }_{47}$ Muslim, 3406, Al-Īmān, Faḍilat al-imām al-'̄àil wa 'uqubāt al-jāìir...; Aḥmad, 6204.
} 
hadith which indicates that one of God's hands is preferable to the other: "The right hand of God is full, and spending liberally day and night would not diminish it. Have you not seen what $\mathrm{He}$ has spent since the creation of the heaven and the earth? What is in His right hand has not diminished. In His other hand is justice; He abases and exalts." ${ }^{48}$ Ibn Taymiyya understands this to mean that grace is in God's right hand and justice is in His other, and he adds that it is known that grace is preferable to justice. Yet, in the event that God's justice should suggest that God commits evil, the shaykh quickly shifts from God's perspective to that of creatures and adds, "Evil does not appear in His names. It appears only in the things that He enacts," and he then sets out the evil attribution typology: "[Evil] is not attributed to Him except by way of the generality, by its attribution to the created cause or by the elision of its agent." ${ }^{49}$

In sum Ibn Taymiyya fluctuates between the first and second types of evil attribution when discussing God's names. Sometimes, he treats the names according to the first type, allowing that some of the names imply evil and asserting that these must be conjoined to, that is, subsumed under the generality of names carrying positive connotations. At other times, he completely denies any implication of evil in God's names and attributes evil solely to what God creates in creatures. As just observed from Thulth, he also switches easily from the first to the second type for the sake of the rhetorical propriety of speaking only of God's goodness.

Although Ibn Taymiyya resembles Ibn 'Arabī in suggesting that creation reflects the diversity of God's names, the shaykh's ideas are far less developed. More importantly, Ibn Taymiyya does not follow Ibn 'Arabī and his devotees in employing the image of God's two hands to elaborate a yang/yin dialectic in God's names or between God and creation. ${ }^{50}$ While Ibn Taymiyya similarly links God's names to good and evil in created reality, he does not mention that this relationship is in any way paradoxical. His primary concern is to avoid attributing evil to God by classifying the diverse data of revelation into the categories of his evil attribution typology. Yet, the fact that his typology is a typology and not a rational resolution implicitly acknowledges a duality of perspective. God's perspective of the generality and wise purpose does not

\footnotetext{
${ }^{48}$ Muslim, 1659, Al-Zakāh; Al-Ḥathth 'alā nafaqa... (The text is not identical); Bukhārī, 6869. Cf. Q. 5:64.

49 Thulth, MF 17:91-4.

${ }^{50}$ On the dialectical or yang/yin interplay of God's two hands in Ibn 'Arabī and his disciples, see Sachiko Murata, The Tao of Islam (Albany, NY: State University of New York Press, 1992), 88-114.
} 
negate that evil is still evil relative to creatures, and the evil perpetrated and experienced by creatures at the level of secondary causes does not nullify the goodness of God. The one perspective cannot be reduced to the other. The following two sections examine how Ibn Taymiyya fills out these two perspectives, first, by articulating God's wise purposes in creation and, second, by seeking to root the cause of evil in humans.

\section{Ibn Taymiyya on God's Wise Purposes in the Creation of Evil}

Ibn Taymiyya consistently argues that God has wise purposes in all that He creates, but he does not often ask what those purposes are, and he sometimes presents little hope that human beings can discover them. In Kasb, for example, he indicates that God has a well-guarded secret in His determination. It is enough to know that God is knowing, wise and merciful. ${ }^{51}$ In Iräda Ibn Taymiyya says that it is sufficient for people to know in general (min haythu jumla) that God has a great wise purpose in both His creation and His command. Yet, he also promises deeper insight for those who grow in faith. The function of this insight is to confirm God's revelation and God's reality:

Each time [the servant] increases in knowledge and faith, some of God's wisdom and His mercy will appear to him that will dazzle his intellect. This will make evident to him to count as true that about which God has informed in His Book, "We will show them Our signs on the horizons and in themselves until it becomes evident to them that He is the Real" (Q. 41:53).52

In Minhäj the shaykh's attitude varies from exhortation against asking questions to suggesting reasons for God's creation of illness and oppression. At one point, he says that it is not for us to ask God "Why?" and he quotes the verse, "God is not questioned as to what He does, but they are questioned" (Q. 21:23). ${ }^{53}$ At another place, he states without further comment that some people may know the wise purposes while others may not. ${ }^{54} \mathrm{~A}$ third passage in Minhāj illumines the human relationship to God's wisdom by comparing our knowledge of God's wise purpose to the ordinary person's awareness of a specialist's knowledge. A non-specialist can recognize that someone is an

\footnotetext{
${ }^{51}$ Kasb, MF 8:399.

52 Iräda, MF 8:97.

Minhäj, 3:67-8/2:5.

${ }^{4}$ Minhäj, 1:146/1:35.
} 
expert in grammar, mathematics, jurisprudence or medicine without being able to understand everything the expert says. Likewise, God's wisdom and mercy can dazzle minds and lead human beings to accept that God is wise and merciful without their understanding God's wise purpose. ${ }^{55}$ Despite this, another passage from Minhäj already noted in Chapter Three reveals more. Ibn Taymiyya says that one cannot know the detail of God's wise purpose, but he does note that, generally speaking, God's creation of illness and oppression leads to humility, repentance from sins and other religious virtues that cannot be attained except by way of difficulty. These evils are preconditions to greater goods that could not otherwise exist. ${ }^{56}$

In $J a b r$, when leading into a mention of the evil attribution typology, the shaykh asserts, “'[God] is not questioned as to what He does' (Q. 38:27). [This is] because of the perfection of His wise purpose, His mercy and His justice, not merely because of His subjugation and His power, as Jahm and his followers say." ${ }^{57}$ The exhortation not to question God would appear to bar any knowledge of God's wise purpose. However, very soon thereafter, Ibn Taymiyya turns quite gnostic, opening the door to knowledge of God's wise purposes for certain spiritually sensitive people:

Some servants may know some of [God's] wise purpose, and what is hidden of it may be hidden from them. People are favored over others in knowledge of His wise purpose, His mercy and His justice. Each time the servant increases in knowledge of the realities of things, he increases in knowledge of God's wise purpose, His justice, His mercy and His power. ${ }^{58}$

Ibn Taymiyya then explains that what the servant comes to understand is that even though God creates and determines all things and that his good deeds come from God, his evil deeds still come from the imperfection and ignorance of his soul (nafs) and God is just in punishing him. It is not clear how this existential knowledge of one's place before God represents knowledge of His wise purpose except possibly that God's wise purpose is that one comes to this particular understanding. In Jabr the shaykh goes on to note that most people are unable to know the detail of God's wise purpose. He adds that even the angels could not discover God's purpose in creating human beings who would shed blood (Q. 2:30). The angels had to be content with general knowledge and belief. ${ }^{59}$

\footnotetext{
5 Minhäj, 5:416/3:104.

6 Minhāj, 3:176-7/2:33.

$7 \mathrm{Jabr}, \mathrm{MF} 8: 511$.

Jabr, MF 8:513.

$59 \mathrm{Jabr}, \mathrm{MF}$ 8:513-4.
} 
The shaykh says much the same thing about angelic knowledge of human nature in Hasana. In God's great wise purpose and mercy, He created evil to be an inevitable constituent of humanity. Reminiscent of Ibn Sīnās assertion that fire would not be fire without burning, Ibn Taymiyya maintains that human beings would not be human had God created them differently and God's wise purpose would not have been realized. Yet, not even the angels, much less humans, know why this is so. ${ }^{60}$ Despite the shaykh's agnosticism concerning God's wise purpose in this particular passage, he provides more indications in Hasana than I have found elsewhere as to what he believes God's wise purposes in the creation of evil to be. He also tells his readers in Hasana that he has expounded the wise purpose and mercy in God's creation of Iblis and Hell in another place, but I have failed to locate this in the shaykh's works. ${ }^{61}$

In Hasana Ibn Taymiyya gives relative evil the educational function of deterrence and guidance away from the wrong path. God's destruction of Pharaoh and his people was evil relative to them, but it served the universal good as a lesson from which future generations might profit. In this regard, the shaykh quotes quranic verses dealing with Pharaoh and his people, "So, when they angered Us, We took vengeance on them and We drowned them all together. We set them as a precedent and an example to later generations" (Q. 43:55-6); and, "Truly, in this is a lesson for those who fear" (Q.79:26).62 Other quranic stories also promote human benefit in that they provide lessons upon which we may reflect and recognize in ourselves something of the disbelief that plagued earlier generations. ${ }^{63}$ Human sin in general serves as a lesson to others by evoking reflection, guidance, and belief. However, the shaykh adds that we should ask God not to make us into an object lesson of this kind. ${ }^{64}$

Ibn Taymiyya also notes that God sends prosperity and adversity, as well as tumult or earthquake (zalzäl), to test believers, purify them from evil, expiate their sins and increase their reward through patience. The blessing of prosperity may in fact be a greater trial than adversity. ${ }^{65}$ In support of these notions, he quotes the following texts among others: "That God might try what was in your breasts and that He might purify what was in your hearts"

\footnotetext{
60 Hasana, MF 14:315.

61 Hasana, MF 14:300-1.

62 Hasana, MF 14:276.

63 Hasana, MF 14:321-2.

64 Hasana, MF 14:307.

65 Hasana, MF 14:254-5 and 304-5.
} 
(Q. 3:154);66 "It may be that you hate something that is good for you, and it may be that you love something that is evil for you. God knows, but you do not know" (Q. 2:216); ${ }^{67}$ and the hadith, "I seek refuge in You from the trial of poverty and the evil of the trial of wealth." ${ }^{\prime 8}$ Also, when discussing God's use of an unjust ruler to ward off even greater injustice, Ibn Taymiyya explains that this injustice expiates the sins of those afflicted by it and increases their reward. He adds, "In [afflictions] they return to God, ask His forgiveness and turn to Him in repentance." ${ }^{69}$

In Hasana Ibn Taymiyya argues, as he does in Minhäj, that evil deeds are a precondition to the virtues of humility and repentance. He makes this point when taking up the hadith, "God did not decree anything for the believer except what is good for him." ${ }^{70}$ How could God's decree of evil deeds inducing punishment be good for the believer? The shaykh first asserts that the hadith appears to be referring to blessings and afflictions and to prosperity and adversity, not to human deeds. However, he then considers the possibility that the hadith encompasses God's decree of human sins as well. He explains that this is good for the believer because it leads to the further good of repentance that could not otherwise occur. The believer is not one who avoids sins entirely, but one who does not persist in them and repents to his own greater good:

The believer is he who does not persist in a sin but repents from it. Thus, it becomes a good deed.... He does not cease repenting from it until he enters Paradise by means of his repentance from it. A sin necessitates a servant's humility, his subjection, invocation of God, his asking Him for forgiveness and his bearing witness to his poverty and to his need for Him and that no one can forgive sins except Him. Because of the sin, good things happen to the believer that would not have happened without this. Therefore, this decree is good for him. ${ }^{71}$

${ }^{66}$ Hasana, MF 14:255.

67 Hasana, MF 14:304.

${ }^{68}$ Bukhārī, 5899, Al-Da'awāt, Al-Isti'ādha min fitnat al-ghinā, in Hasana, MF 14:305.

${ }^{69}$ Hasana, MF 14:269.

70 Ảhmad, 12439, Bāqī musnad al-mukaththirīn, Musnad Anas b. Mālik. Ibn Taymiyya, Mahabba 156, also discusses this hadith in the context of God trying believers with both prosperity and adversity.

${ }^{71}$ Hasana, MF 14:318-9. This focus on the goodness of sin with repentance in Hasana correlates with the findings of Shahab Ahmed, "Ibn Taymiyyah and the Satanic verses," 86-7 and 90-100, concerning Ibn Taymiyya's view of prophetic protection ('isma) and the exemplary repentance of the prophets. According to Ahmed, the shaykh regards prophetic 'isma not as complete protection from committing sins (the widespread Sunnī belief in medieval and modern times) but as protection from persisting in sins already committed. In Ibn Taymiyya's view, the prophets, including the Prophet Muhammad, sinned, but they 
Here, as in other brief notes on the good of evil examined above from Hasana and Minhäj, the good in evil and one's own adversity and sin is the opportunity afforded to advance in the religious life. Elsewhere, Ibn Taymiyya notes as well that the unbelief of unbelievers is a blessing for believers in that it gives them occasion for jihād and moral exhortation. Similarly, the existence of satans provides believers opportunity to gain the highest rewards and spiritual levels through striving, showing enmity and resisting caprice. ${ }^{72}$ However, Ibn Taymiyya does not go on in Hasana or any other text to my knowledge to note the implications for God in the fashion of his close disciple Ibn Qayyim al-Jawziyya, who explains that sins and disobedience afford God Himself the occasion to demonstrate His mercy and forgiveness and that God's joy in repentance depends upon there being something from which human beings repent. ${ }^{73}$ Concern to protect God's self-sufficiency is probably what prevents Ibn Taymiyya from speaking of the vicissitudes of creatures giving God opportunity to exercise His attributes.

Whatever be the case, the shaykh does maintain in Hasana that everything that God creates is a blessing to His servants revealing His wisdom, mercy and power. He adds, "In everything that God creates is beneficence to His servants for which $\mathrm{He}$ is praised with the praise of thanksgiving. And in it He has a wise purpose that returns to Him because of which He has a right to be praised for it with a praise to which $\mathrm{He}$ has a right in His essence." ${ }^{.74} \mathrm{~A}$ little later in Hasana, Ibn Taymiyya complements this with, "In everything that $\mathrm{He}$ creates, $\mathrm{He}$ has a wise purpose, and $\mathrm{He}$ is praised for [what $\mathrm{He}$ creates] in consideration of that wise purpose." 75 Although the shaykh does not put it so simply, it seems clear enough that God is praised not only for His beneficence to creatures but also for His essence in which wisdom is inherent. Ibn Taymiyya then criticizes the Qadarīs (i.e. Mu'tazilīs) for asserting that

immediately repented from their sins and did not remain in them. Through sin and repentance, the prophets attained greater perfection (kamäl) than they could otherwise have attained. This pattern of immediate repentance from sins then serves as an example for all believers to follow, and it nurtures the devotional virtues of repentance and asking for forgiveness. It might be thought that Ibn Taymiyya encourages sinning in order to gain the greater good of repentance. However, Ahmed, 93 n. 64, highlights, but does not translate, a text in Minhäj, 2:400/1:227, where Ibn Taymiyya cautions against this. The passage reads, "There is no doubt that evil deeds are not commanded, and it is not for the servant to commit them in order thereby to repent from them.... [This is] like someone who wants to eat poison and then drink the antidote. This is ignorance."

${ }_{72}$ Mahabba, 160.

73 Ibn Qayyim al-Jawziyya, Shifäa al-'alìl, 486.

${ }_{74}$ Hasana, MF 14:301-315 (quote on 302).

75 Hasana, MF 14:309. 
God creates with wise purpose to the profit of creatures but without return to Himself. With such a God, praise is nothing more than thanksgiving for profit gained, and consideration is given neither to His sovereignty nor to confessing His exclusive divinity (tawhìd al-ilähiyya), that is, His right to worship in His essence. Additionally, Ibn Taymiyya condemns the Jahmīs (i.e. Ash'arīs) for holding to God's sovereignty and exclusive lordship (tawhid al-rubübiyya) without confessing His wisdom or exclusive divinity. The Jahmī God who creates pure evil devoid of wise purpose, profit and mercy is worthy of blame and has no right to praise or love. Rather, "[Praise] is for His blessing, and it is worship of Him for His divinity, which includes His wise purpose. ${ }^{.76}$

This discussion of the Hasana material has drifted from God's wise purposes in the creation of evil onward to God's essence and divinity, thus reflecting Ibn Taymiyya's keenness to affirm not only wise purposes in God's acts but also, more profoundly, the wise purpose inherent in God's essence and God's praiseworthiness in that. For Ibn Taymiyya, God's right to worship is essential, and it is from this that His wise purpose flows, even to His creation of evil, which serves to expiate sin, guide human beings and nurture religious virtues such as humility and repentance that lead to recognition of His exclusive divinity. In this light, the shaykh's interpretation of evil is very much that of the Sufis for whom it is God's tool of discipline for spiritual growth.

\section{Ibn Taymiyya's Location of the Origin of Evil in Nonexistence ('adam)}

In texts examined in Chapter Four, Ibn Taymiyya deems the substrate principle a sufficient defense of God's justice in creating and punishing human bad deeds. God is not qualified with the bad deeds that $\mathrm{He}$ creates and $\mathrm{He}$ is just to punish these acts because $\mathrm{He}$ creates them in a substrate other than Himself. In two major theodicean texts-Hasana and Fätiha-Ibn Taymiyya goes beyond the substrate defense of God's justice and attempts to free God entirely from creating gratuitous evil deeds by locating their origin in nonexistence. The following two sections examine how the shaykh employs nonexistence to deal with the origin of evil in Hasana and Fätiba, respectively. Rooting evil in nonexistence probably represents a development

\footnotetext{
${ }^{76}$ Hasana, MF 14:309-313 (quote on 311).
} 
in Ibn Taymiyya's thought, but this cannot be shown definitively due to difficulty in establishing a precise chronology for his theodicean writings.

\section{Exclusive Divine Goodness and the Origin of Evil Deeds in Hasana}

\section{Interpreting Q. 4:78-9: Everything Is from God; Evil Is from the Soul}

Precedents for the notion of evil as privation or nonexistence ('adam) are found in Ibn Sīnā and Ibn 'Arabīi. ${ }^{77}$ Whereas these thinkers draw on the concept of privation primarily for metaphysical reasons, Ibn Taymiyya employs it in Hasana to address a more typically Mu'tazili concern, that of upholding God's order of retribution and absolving God of being the ultimate source of moral evil. Some material from Hasana has already been examined in this and previous chapters, but the central problem of the treatise-the origin of evil-has yet to be addressed. Much of the text wrestles with an apparent contradiction posed by two quranic verses that occur in a context of commanding jihad and blaming those who try to evade it (Q. 4:65-104). ${ }^{78} \mathrm{Ibn}$ Taymiyya writes:

One group thought that there was in the verses an ambiguity or contradiction in the outward sense where [God] says, "Everything is from God" (4:78), and then differentiates between good things (basanät) and evil things (sayyi'ät). He said, "Any good thing that comes to you is from God and any evil thing that comes to you is from yourself (min nafsika)" (Q. 4:79). This is due to their insufficient understanding and their not meditating on the verses. In these verses is no contradiction (tanāqü $)^{79}$

If God is the source of all things, do not evil things also come from Him and not from creatures? Ibn Taymiyya does not specify the group posing this contradiction, but he does mention earlier Kalām attempts to resolve it. The shaykh cites a Mu'tazilī proposal that Q. 4:79 refers to God's command. On this reading all good comes from God only in the sense that He commands it. He does not necessarily create it. The nafs, which I will translate variously as "self," "soul" or "person," creates both obedience and disobedience and is thus the source of evil things. Ibn Taymiyya rejects this

77 For references in Ibn Sīnā and Ibn 'Arabī, see above at the beginning of this Chapter. Fakhr al-Dīn al-Rāzī also elaborates on evil as nonexistence in one of his works, his philosophical al-Mabāhih al-mashriqiyya, 2:519-523. Al-Julaynad, Qadiyyat al-khayr wa al-sharr, 161-4, explains that al-Rāzī's departs from Ash'arī tradition with these ideas.

78 Ibn Taymiyya, Hasana, MF 14:229-233, surveys the context that these verses constitute for Q. 4:78-9.

79 Hasana, MF 14:248-9. 
interpretation because "Everything is from God" (Q. 4:78) precludes human beings creating their own acts. ${ }^{80}$

The shaykh also notes an interpretation that he traces to the Ash 'ari theologian Abū Bakr b. Fūrak (d. 406/1015). In this view, the end of Q. 4:79 should be read as an interrogative, "Any evil thing that comes to you, is it from yourself?" which must be answered negatively because all things come from God. Ibn Taymiyya discards Ibn Fūrak's interpretation as grammatically untenable. The shaykh argues instead that the verse refutes any depreciation of the human role in acts because it indicates that at least some deeds come from the person himself. ${ }^{81}$

In a brief discussion of these verses in Iräda, Ibn Taymiyya interprets good things and evil things as strictly blessings and afflictions. The evils of affliction are only from the person in the sense that God sends them as punishment for sins that God also creates. The shaykh states clearly that good things and evil things are not acts of obedience and acts of disobedience, respectively, such that God could be said to create the former but not the latter. ${ }^{82}$ In Hasana, however, he locates the ultimate source of disobedient acts more firmly in human beings. While hasanät and sayyi $\bar{a} t$, which I have been translating "good things" and "evil things" respectively, do refer to blessings and afflictions, Ibn Taymiyya argues that they may also be said to include obedience and disobedience. For this reason, I will sometimes translate hasanāt and sayyi ät as "good deeds" and "evil deeds." In this light, the shaykh reads Q. 4:79 to mean that obedience is a blessing that comes to a person from God while disobedience is an affliction that comes to him because he himself, in some sense, does it. ${ }^{83}$

Ibn Taymiyya explains this interpretation by drawing a distinction between a deed and its recompense ( $j a z \vec{a}$ ) of punishment or reward. God may punish a first act of disobedience with a second act of disobedience, and He may reward a first good deed with a second good deed. The shaykh illustrates this from the Qur'an at length. Three of his quotations will suffice here: "By [the Book], God guides whoever follows His good-pleasure in the ways

${ }^{80}$ Hasana, MF 14:246-7, 258-9. Gimaret, Théories de l'acte humain en théologie musulmane, 347-352, surveys this and other interpretations of 4:78-9 found in the classical Kalām and tafsir literature.

${ }^{81}$ Hasana, MF 14:247, 421-4.

82 Iräda, MF 8:114-7.

${ }^{83}$ Hasana, MF 14:234-9. Similar interpretations of 4:78-9 may be found in the commentaries of al-Tabarī, Tafsìr al-Tabarì: Jämi' al-bayān 'an ta' wìl àyy al-Qur'àn, ed. Mahmūd Muhammad Shākir (Cairo: Dār al-Ma ārif bi-miṣr, n.d.), 8:555-560; and Abū al-Qāsim Jār Allāh al-Zamakhsharī, Al-Kashshāf (Beirut: Dār al-kutub al-'ilmiyya, 1415/1995), 4:527. 
of peace" (Q. 5:16); "Then the unbeliever was confounded. God does not guide people who are unjust" (Q. 2:258); and, "We shall turn their hearts and their eyes, as they did not believe in it the first time, and We shall leave them in their insolence to wander blindly" (Q. 6:110). From this evidence that God rewards and punishes deeds with other deeds similar in kind, the shaykh concludes that the key phrase at the end of Q. 4:79, "from yourself," encompasses both sins gratuitously perpetrated and God's creation of evil deeds as punishment. As for good deeds, however, God creates both the acts and their recompense in keeping with "Any good thing that comes to you is from God." ${ }^{4}$

Having established that evil things originate only in the very person afflicted, Ibn Taymiyya refutes a charge that the Prophet and his message are sources of evils and afflictions, as in Q. 4:78: "If a good thing comes to them, they say, 'This is from God', and if an evil thing comes to them, they say, 'This is from you [Muhammad]'. Say, 'Everything is from God." The shaykh invokes the context of this verse in the Muslim setback at the Battle of Uhud and places the blame for its afflictions not on the Prophet but on the sins of the Muslims. ${ }^{85}$

\section{All Good Comes from God's Unmerited Blessing}

Even though Ibn Taymiyya imbues "Any evil thing that comes to you is from yourself" with a strong sense of retributive punishment in Hasana, it is difficult to see how this fits with his conviction that both good and evil deeds are created and predetermined by God. What is the sense in which human beings are the sources of their evil deeds? The shaykh himself presents the problem clearly:

If acts of obedience and acts of disobedience are predetermined (muqaddar) and blessings and afflictions are predetermined, then what is the difference between good things, which are blessings, and evil things, which are afflictions, so as to deem the one from God and the other from the human soul? ${ }^{86}$

In response, Ibn Taymiyya elaborates a series of eight "differences ( furüq)" between good things and evil things. ${ }^{87}$ The fourth and eighth differences do not address the question directly and may be summarized briefly. The

\footnotetext{
${ }^{84}$ Hasana, MF 14:239-247.

85 Hasana, MF 14:248-254, 342. Cf. Hasana, MF 14:373-5.

${ }^{86}$ Hasana, MF 14:259.

87 These eight differences vary in length from one paragraph to fifty-four pages in the printed text. The one-paragraph discussions are the first (MF 14:260) and the third (MF 14:265). The fifth is the longest (MF 14:277-331). The eight discussions together take
} 
fourth observes that evil is relative and provides a three-fold evil attribution typology along lines examined earlier in this chapter. ${ }^{88}$ The eighth difference says simply that disgusting circumstances are appropriate for those who do disgusting things (khab-ith). It is not fitting for such people to reside in Paradise as Paradise is only appropriate for those who have been purified from their sins. ${ }^{89}$

The remaining differences work toward resolving the contradiction. In the first three and the seventh, Ibn Taymiyya underscores God's great beneficence. God distributes blessings (sg. ni $m a$ ) and grace ( $f a d l$ ), such as health, guidance, belief and good deeds, apart from consideration of human worthiness, and God brings people into Paradise out of pure grace without respect to their deeds. With respect to evil deeds, moreover, God limits His punishment strictly to what retribution requires. ${ }^{90}$ The following passage from the second difference epitomizes this perspective:

All that intelligent beings enjoy of the two goods of this world and the hereafter is pure blessing from Him without a preceding cause making it their right. They have neither might nor strength from themselves except through Him. $\mathrm{He}$ is Creator of their souls, Creator of their righteous deeds and Creator of recompense. So, His statement, "Any good thing that comes to you is from God" (Q. 4:79), is true in every respect, in the outward sense and the inward sense, according to the doctrine of the Sunnis. As for an evil thing, it is only from the sin of the servant, and the sin is from himself. [God] did not say, "Truly, I did not predetermine this, and I did not create it." Instead, He mentioned to human beings what profits them. ${ }^{91}$

According to Ibn Taymiyya, the profitable thing that God has mentioned is the latter part of Q. 4:79: "Any evil thing that comes to you is from yourself." "From yourself" benefits humankind by prompting repentance and entreaty for forgiveness of sins. With this in mind, the shaykh interprets "Everything is from God" (Q. 4:78) to mean that blessings, afflictions and acts of obedience and disobedience are all from God. The second verse (Q. 4:79) then differentiates between blessings and evil in order to motivate thanksgiving to God for the former and seeking forgiveness from Him for the latter. ${ }^{92}$ This interpretation involves a shift from a retributive scheme of reward for good

up just under half of Hasana, specifically 87 out of 197 pages in the printed text (MF 14:259-346).

${ }^{88}$ Hasana, MF 14:266-277.

89 Hasana, MF 14:343-6.

90 Hasana, MF 14:260-5, 339-342.

91 Hasana, MF 14:261.

92 Hasana, MF 14:261-5. A similar argument is made in Hasana, MF 14:319-320. 
deeds to a logic of pure grace and blessing in which God is the sole source of all good. The substrate principle noted in Chapter Four above no longer applies in good deeds. Good deeds are not attributed to the human in whom God creates them to subsist but to God's unmerited blessing. Retribution is left to operate strictly on the level of evil deeds. This interpretation of Q. 4:78-9 may nurture a reverent attitude toward the goodness of God, but it does not explain how pure grace in good deeds coexists with retribution in evil deeds.

\section{The Source of Evil Deeds Is Ignorance, which Is Nonexistent}

Ibn Taymiyya grapples with the logic of reward and punishment more extensively in the fifth and sixth differences in Hasana, vacillating at first between retributive based and blessing based approaches to reward before concentrating on a retributive scheme in punishment. At the beginning of the fifth difference, the shaykh explains that all good deeds with which God blesses human beings are existing things (umür wujüdiyya). Furthermore, omission (tark) of what is prohibited is just as existent as obedience to a command. Omission of a prohibited act is existent because it involves a person's "knowledge that it is a bad sin and that it is a cause of chastisement, his loathing and his hatred of it, and his restraint of himself from it when he desires it, craves it and seeks it.." ${ }^{93}$ Ibn Taymiyya then speaks retributively, noting that human beings are only rewarded for good deeds if they undertake them with explicit intention and love for God. Similarly, they are only rewarded for omitting evil deeds if they omit them out of hatred for them and loathing for worship of any apart from God. Moreover, there is no reward for omitting a forbidden deed that one never thought to commit, and there is no punishment for omitting to do what is commanded unless there is a perverse refusal to obey. Reward and punishment apply only to the existent-or we might say intentional—commission of good deeds and evil deeds, respectively. There is neither reward nor punishment for someone who does not know that his deeds are good or evil. Such a person is in a state of unaccountability similar to that of children and the insane. The shaykh ends this part of his discussion by turning from the retributive perspective to that of God's unmerited blessing. All rewarded good deeds are existent and a blessing from God: "It is He who makes belief beloved to the believers

\footnotetext{
${ }^{93}$ Hasana, MF 14:278.
} 
and adorns it in their hearts, and [it is He] who makes disbelief, iniquity and disobedience hateful to them." ${ }^{94}$

Ibn Taymiyya returns to retribution in the fifth difference by tracing evil deeds variously to injustice, heedlessness (ghafla), craving (shabwa), caprice ( haw $\bar{a}$ ), Satan and the soul's hatred for what is obligatory. However, he roots evil deeds ultimately in ignorance or the lack of knowledge. God has created humans in their natural constitution ( fitra) to love knowledge and to gain what profits them and gives them pleasure. Moreover, God has given His guidance: "God-Exalted is $\mathrm{He}$-has guided humanity with general guidance by the knowledge and the means of knowledge that He put in the natural constitution and by the books He sent down to them and the messengers $\mathrm{He}$ sent to them." 95 Moreover this guidance and knowledge will restrain from evil. Human beings will decide to perform good deeds and avoid evil deeds if they are adequately aware of the profit entailed in doing so: "The root of what makes people fall into evil deeds is ignorance and not knowing that they will harm them with preponderant harm, or thinking that they will profit them with preponderant profit." 96 The shaykh argues that a thief will not steal if sure of getting caught and an adulterer will not commit adultery if certain of being stoned. Wine drinkers, however, present a more difficult problem. Ibn Taymiyya observes that punishment does not necessarily stop them from drinking. However, he does not explore why this is so; instead, he notes that the death penalty may be necessary for the inveterate drinker. ${ }^{97}$

It is difficult to reconcile Ibn Taymiyya's view of ignorance as the source of evil with his notion that only perverse and existent disobedience is punished retributively. On the one hand, and as noted in the preceding paragraph, he argues that human beings given proper guidance will necessarily do what they should since this will be the course of action most profitable for them. He believes that they will never perversely disobey God in full awareness of the consequences, and he does not allow the observation of incorrigible wine drinkers to disturb this conviction. No one will disobey knowing full well that it will lead to his own ruin. Perversity is therefore impossible. On the other hand, Ibn Taymiyya explains that punishment is due only for the existent omission of obligatory deeds, that is, for disobedience that is perverse and intentional. Now the difficulty is this: If a knowledgeable person will not disobey, and if a person who disobeys does so only for lack

${ }^{94}$ Hasana, MF 14: 277-287 (quote on 287).

95 Hasana, MF 14:296.

96 Hasana, MF 14:290.

${ }^{97}$ Hasana, MF 14:287-294. 
of knowledge and proper guidance, then there will be no justly administered retributive punishment because no act of disobedience is truly perverse. ${ }^{98}$ The disobedient is always ignorant and therefore unaccountable. The notion that lack of knowledge is the fundamental root of evil deeds renders a retributive scheme that punishes only existent or perverse deeds superfluous. Punishment, however, may be administered for other than retributive reasons, such as deterrence and education, which make evil deeds and their consequences known for what they are: harmful to the human soul. As observed above, Ibn Taymiyya does indeed supply these kinds of reasons in Hasana.

The evident reason that Ibn Taymiyya locates evil deeds in ignorance and lack of knowledge is to clear God of being the source of evil. Continuing in the fifth difference, he argues that the nonexistence that is ignorance and lack of knowledge is nothing at all. It has no agent and therefore cannot be attributed to God. God is the source only of existent things, not of ignorance. ${ }^{99}$ In the same context, the shaykh explains that God creates the soul constantly willing and moving. When it does not turn toward God in its ignorance, it necessarily turns away from Him and worships something else. Such a person suffers recompense through not "living the profitable life for which he was created." ${ }^{100}$ Yet, it remains unclear how the God who creates all human acts can hold human beings responsible for their ignorance, and it is not apparent why human beings lack adequate knowledge in the first place. Ibn Taymiyya concludes the fifth difference in Hasana by discussing the attribution of evil to its final cause, that is, to wise purpose, and to its agent or secondary cause, as was noted above. With this, the shaykh looks away from the origin of evil to God's wise purpose in all created things.

\section{Punishment Is for a Lack of the Deeds for which One Was Created}

In the sixth difference, Ibn Taymiyya returns to the problem of evil's ultimate source and makes his final and fullest attempt in Hasana to explain how God is just to punish human sins retributively. Substantial portions of this discussion are translated below. Ibn Taymiyya begins, "The existent sins (al-dhunūb al-wujüdiyya) by which the servant is tried-even if they are a creation of God-are his punishment for his not doing what God created

98 Aspects of the problem outlined here are not unique to Ibn Taymiyya. According to Hourani, Islamic Rationalism, 92-7, the Mu'tazilī theologian 'Abd al-Jabbār argues that humans will not do bad deeds if they know both that such deeds are evil and that there is no advantage to be gained in doing them.

99 Hasana, MF 14:294.

100 Hasana, MF 14:297. 
him to do and what He constituted him naturally to do." ${ }^{101}$ The fundamental problem is the failure of human beings to commit the good deeds for which they were created and the deeds that humans should know to do through the guidance of their natural constitutions. In order to free God from responsibility for having created this failure and to render Him just in punishing it retributively, Ibn Taymiyya calls it a nonexistent that God does not create. This nonexistent is not punished with the complete punishment of the Fire, but it is punished by God's creation of evil deeds. The shaykh explains that this is a middle position between complete punishment for a pure lack of good deeds, a view he attributes to the Mu'tazilī Abū Hāshim al-Jubbā'ī (d. 321/933), and complete punishment of only existing evil deeds such as the intentional omission of good deeds. ${ }^{102}$ He elaborates:

What has been mentioned in this respect is a median position (amr wasat). That is, [God] punishes [the servant] for this lack [of good deeds] with his commission of evil deeds, not with [complete] punishment of them. He does not punish him for them until He sends His messenger. When he disobeys the messenger, at that moment he deserves complete punishment. At first, he is only punished by that from whose evil he can be saved by repenting or by not being held accountable. He is like a boy who does not occupy himself with what profits him but with what is a cause of his harm. However, the pen of sinful things will not write anything against him until he reaches the age of accountability. When he reaches the age of accountability, he will be punished. Then, the evil deeds to which he has grown accustomed may be a cause of his disobedience after reaching the age of accountability. He has not been punished except for his sin, but he only deserves the conventional punishment after being made accountable. As for his preoccupation with evil deeds, this is punishment for his not committing good deeds.

Hence, evil is not [attributed] to God in any respect. Even if God is the Creator of the servants' acts-His creation of obedient acts is blessing and mercy, and He has a wise purpose and mercy in His creation of evil deeds - this is nonetheless just of Him. He is not unjust to humans at all, but humans are unjust to themselves. Their injustice to themselves is of two kinds: their not committing good deeds - this is not attributed to Him—and their commission of evil deeds-He creates them as their punishment for omitting to commit

101 Hasana, MF 14:331.

102 Hasana, MF 14:333. Ibn Taymiyya, Hasana, MF 14:281-2, takes an explicit position against Abū Hāshim al-Jubbāà who says that failure to fulfill an obligation is not an act at all. Abū Hāshim's father Abū 'Alī took the opposite position (i.e. that adopted by Ibn Taymiyya), saying that omission of a duty is in itself a real act. Both father and son agree, however, that God punishes failure to fulfill duties. For a brief description of the controversy, see Martin J. McDermott, The Theology of al-Shaikh al-Mufid (d. 413/1022) (Beirut: Dar el-Machreq, 1978), 157-9. 
the good deeds for which He created them and which He commanded them. Every blessing from Him is grace, and every vengeance from Him is just.

It will become clear to whoever meditates on the Qur'an that, generally, God makes whatever He mentions in the way of creating unbelief and acts of disobedience as a recompense for these deeds. [This is] as in His statementExalted is He-"Whomever God wills to guide, He opens his breast to Islam. Whomever He wills to misguide, He makes his breast narrow and tight as if he were climbing up to the sky. In this way, God makes an atrocity for those who do not believe" (Q. 6:125). And He-Exalted is He-says, "So, when they turned away, God turned their hearts away" (Q. 61:5). And He-Exalted is He-says, "As for him who is a miser and self-sufficient and belies goodness, We will ease his way into hardship" (Q. 92:8-10). In this and similar examples they executed deeds by which He punished them for committing what was forbidden and omitting what was commanded. These things were only from them and created in them because they did not do that for which they were created. They must inevitably have motion and a will. When they were not active with good deeds, they were active with evil deeds out of God's justice since He put this in its place, in its substrate, which is susceptible to it, namely, the heart, which is not [existent] except [as] committing deeds. If it does not commit a good deed, it will be employed in committing an evil deed. As it was said, "As for your soul, if you do not occupy it, it will occupy you."103

Following this, Ibn Taymiyya briefly notes that Jabrīs assert that God could punish unbelief and disobedience that $\mathrm{He}$ creates without wise purpose and that Qadarīs maintain that humans create their own acts. He also mentions that many Qadarīs allow God to create sins in recompense but do not permit God to create the first sin that a person commits lest God be unjust to punish it. ${ }^{104}$ Ibn Taymiyya likewise excludes the first sin from the realm of God's creation, but, unlike the Qadarī, he also does not attribute its creation to the human. He maintains that it is not created by anyone because it is not an existent. Rather, it is the nonexistence of the good deeds for which the human was created. The first sin in the life of each individual human being is a passive failure to cooperate with God's intention for him. It is a privation of what God meant human beings to do and be, and this privation has neither a divine nor a human agent. In the following passage from the sixth difference in Hasana, the shaykh elaborates this and then briefly addresses why humans do not do that for which they were created in the first place:

What we have mentioned necessitates that God is Creator of everything. Nothing originates except by His will and power. Nevertheless, the first of the existing sins is the [one] created, and this is a punishment for the servant's not

103 Hasana, MF 14:333-5.

104 Hasana, MF 14:335-6. 
doing that for which he has been created and that which he is supposed to do. It is not permissible to attribute this lack to God. It is not anything so that it would enter into our statement, "God is the Creator of everything." The first of the existent sins that $\mathrm{He}$ originates is a punishment of the servant for this lack. The rest [of the sins] may either be a punishment of the servant for what exists or they may be a punishment for his continuation in [this] lack. As long as he does not consecrate deeds to God, he is still an associationist, and Satan still has authority over him.

Then, His specification (takbsīs) - Glory be to Him - of whom He guidesto employ him from the beginning in that for which he was created and not so to employ another-is a specification of His by His grace and mercy. Therefore, God says, "And God chooses whomever He wills for His mercy. God is the owner of abounding grace" (Q. 2:105). In this is wise purpose and mercy about which He knows better, as when He specifies some bodies (abdān) to have strengths not found in others. Because of the lack of strength, [a body] might suffer diseases that are existent and other than that in His wise purpose. By verifying this, [the servant] wards off the obscurities of this subject, and God knows better what is correct. ${ }^{105}$

Locating the origin of evil in the nonexistent failure of human beings to do that for which they were created may succeed in granting some semblance of libertarian freedom and establishing a basis upon which to mete out retributive punishment. However, making nonexistence the origin of this failure does not explain convincingly why human beings fall passively into their initial sins. In the passage above, the shaykh appears to sense these problems, and he turns away from arguing on the plane of retribution and shifts back to God's grace and wise purpose. Ultimately, there is no explanation for human weakness but God's wise purpose and mercy. Ibn Taymiyya's attempt to find a basis for retributive judgment in nonexistence still has its further grounding in God's wise purpose in setting up the creation as He has and in creating some human beings to dissipate their energies in unprofitable deeds.

\section{Call on God Alone Because He Is the Sole Source of Good}

Summing up the previous subsections, Ibn Taymiyya's dominant viewpoint on God's recompense in Hasana differs substantially from that of the substrate principle in which the good and bad deeds that God creates are both attributed to human beings. With the substrate principle, retributive justice operates in both good and bad deeds from the human perspective, while God from the divine perspective creates everything according to His wise purpose. In Hasana, however, the shaykh often maintains that humans should take

${ }^{105}$ Hasana, MF 14:336-7. 
the perspective of God's all-comprehensive goodness in blessings and good deeds but the human retributive perspective in evil deeds and afflictions. Good things point to God alone, not to human achievement, while evil things always point to lack and failure in the individual afflicted. Neither God nor human beings create this failure; it has no agent. Yet, human beings are responsible for allowing this failure to occur to them, and they suffer the punishment of God creating evil deeds in them as retribution.

The shift from the substrate principle to God as the unique source of all human good deeds also carries ethical and spiritual import for Ibn Taymiyya in Hasana. Noted above was his claim that Q. 4:79 indicates what is profitable for human beings: the conviction that all blessings come from God evokes thanksgiving, while knowledge that evil deeds come only from the soul promotes seeking forgiveness. In the latter parts of Hasana, he also contends that no intercession (shafä $a$ ) should be sought except from those to whom God gives authority to intercede before Him, and he criticizes beliefs and practices that he believes violate God's Law and detract from calling on God alone. While God has a right to worship in His very essence, it is also the case that, as the sole source of all good things, He should be the sole object of complete trust, hope, praise and invocation. ${ }^{106}$

\section{The Origin of Evil in Human Imperfection and Lack in Fātiha}

Whereas the shaykh introduces the notion of evil as nonexistence in Hasana primarily to solve a rational difficulty dealing with retribution, he elaborates it in Fätiha with much greater philosophical detail and analysis to make a religious argument. Fätiḩa opens with a full treatment of complete trust in God and God's exclusive and essential right to worship. This constituted a key source for my discussion of "worship" and "asking for help" found above in Chapter One. ${ }^{107}$ Following this, Ibn Taymiyya takes up evil in order to argue that, since no good comes from creatures, appealing to them for help is like seeking aid from nothing at all. Thus, human weakness, imperfection, and ultimately nonexistence show that God alone should be sought for help. ${ }^{108}$

Ibn Taymiyya begins the part of Fätiha on evil by affirming that God is Creator of all existent things. The human soul contributes only nonexistence, which is nothing at all and requires no agent. Now, according to the shaykh,

106 Hasana, MF 14:314-5, 341, 359-421.

107 Fätiha, MF 14:4-15.

${ }^{108}$ Fätiha, MF 14:15, 29. 
the nonexistence of something may be due to the lack of an entailing factor (muqtadī) or the existence of an impediment (māni $\left.{ }^{i}\right)$. However, God's will $(m a s h \vec{i} a)$ is always decisive in necessitating the existence of something: "The will of [God] is the perfect cause (al-sabab al-kamil). With its existence there is no impediment, and with its nonexistence there is no entailing factor." With these metaphysical bases in place, the shaykh explains that all good comes from God and that no good comes from the soul. ${ }^{109}$

Ibn Taymiyya then identifies two kinds of evil: the nonexistent and the existent. ${ }^{110} \mathrm{He}$ explains that a nonexistent evil may be the nonexistence of an essence, the privation of an attribute of perfection such as life, knowledge, speech and the like, or a lack of good deeds such as loving and turning to God. The existence of such things is good, and their privation is evil. However, this privation has no agent or creator. Thus, it is not attributed to God but to the soul as a concomitant of the way God created it. In other words, evil, imperfection and privation are essential elements of human nature:

[This privation] is only from the necessary concomitants of the soul, which is the reality of the human being, before it is created and after it has been created. Before it is created, it is nonexistent, which makes this privation follow necessarily. After it has been created-it having been created weak and imperfect-there is imperfection, weakness and impotence in it, and these things are nonexistent. They have been attributed to the soul as the attribution of the nonexistence of the effect to the nonexistence of its cause. ${ }^{11}$

Following this, Ibn Taymiyya again notes that the nonexistence of something may be due either to the lack of its agent or to an impediment, and, as before, he mentions that no impediment can impede God's will. However, he adds that God may create one thing to be a secondary cause (sabab), another thing an entailing factor, and yet another thing an impediment. In this case, the impediment impedes the cause until God makes the cause complete (tämm). With this in view, the shaykh explains, "These nonexistent evil deeds are only attributed to the servant, sometimes due to the lack of a cause from him, and at other times due to the existence of an impediment from him." The lack of a cause consists in servants having no strength and good in themselves. Impediments include impotence and preoccupation with deeds that logically preclude other better deeds. ${ }^{12}$

109 Fätiḥa, MF 14:15-7 (quote on 17).

110 Fätiha, MF 14:18-24.

111 Fätiha, MF 14:18.

112 Fätị̆a, MF 14:19-20 (quote on 19). 
Some discussion of the second kind of evil in Fätiha - existent evil-has already been given earlier in this chapter. This evil is not absolute, and, from God's perspective, it is wholly good by virtue of God's wise purpose. Following the three-fold evil attribution typology, however, it is also attributed to its secondary cause, and, "The secondary cause of this existent, particular, restricted evil is either nonexistent or existent." 113 As examples of the nonexistent type of secondary cause, Ibn Taymiyya notes the lack of a condition or the lack of part of a cause. This is as when a cause of pleasure and good is fully present, but the condition is lacking, which causes pain. More concretely, the lack of hearing causes the pain of deafness; the lack of health causes pain and illness; and so on. The shaykh clarifies furthermore that the servant commits forbidden acts and suffers their harm only out of ignorance and need which arise out of nonexistence, specifically, the nonexistence of knowledge and the nonexistence of sufficiency $($ ghin $\bar{a})$, respectively. As examples of existent secondary causes of existent evil, Ibn Taymiyya cites commission of forbidden deeds leading to punishment and blame, eating harmful foods and forceful movements inducing pain. These existents are imperfect because they do not cause pure good, and the shaykh traces them back to other lacks such as the lack of complete examination and listening, which themselves go back to either pure nonexistence or the impediments of pride and envy. Pride results from a vain imagination that arises out of the soul's lack of sufficiency in the Real, and envy originates in a lack of the level of blessing that would bring the envious on a par with the envied. Similarly, murder and adultery occur because someone cannot fulfill his need in some other way, and the source of this need is nonexistence. ${ }^{114}$ The distinction between nonexistent and existent causes of existent evil dissolves in the final analysis to nonexistence because the existent causes of evil are always imperfect, and imperfection itself is rooted in nonexistence.

Ibn Taymiyya elaborates further in Fätiha that pure nonexistence cannot cause existence and that existence is not a cause of nonexistence because nonexistence does not need an existent cause. He again notes that pure existence is completely good, and he then divides evil into pain on the one hand and causes of pain on the other. As an example of a cause of pain, he notes evil deeds leading to chastisement. Pain results from a privation, as in the separation of something that should be connected. Sins that cause pain arise initially from not meeting obligations, which opens the door to

113 Fätiha, MF 14:22.

114 Fätiḩa, MF 14:23-4. 
committing forbidden acts. The shaykh ends the section on evil in Fätiha by explaining that human beings should seek refuge in God from both the evil deeds they commit and the pain and punishment that these deeds bring. ${ }^{115}$ In the remainder of the treatise, he expands on the human need for God to be the object of his worship Whom he loves for His essence and on the need to rely totally on the God from Whom all blessing and help come. ${ }^{116}$

\section{Conclusion}

In the evil attribution typology presented at the beginning of this chapter, Ibn Taymiyya identifies three ways of speaking about evil. Reviewing these in reverse order, the third type consists in eliding the agent of evil, presumably God, and giving the respective verb in the passive voice. This is a rhetorical courtesy, which the shaykh does not elaborate further except to cite a few examples from the Qur'an. The second type diverts attention from the Creator and attributes evil solely to its secondary cause, that is, to the creature that commits it. The first type attributes evil to the generality of what God creates. This type is interpreted along Avicennan lines in three ways: evil is a necessary concomitant of God's creative activity; evil is harmful only relative to particular persons but wholly good by virtue of God's wise purpose in creating it; and evil is minuscule compared to the great quantity of good.

Ibn Taymiyya is often reticent to speculate on the specifics of God's wise purposes in the creation of evil, and he sometimes notes that it is sufficient to believe simply that God has a wise purpose in all that He does. In a few places, however, and especially in Hasana, the shaykh explains that evil has the educational function of deterring others from bad deeds and the religious functions of purifying through testing, expiating sins, providing opportunity to earn reward and developing virtues such as repentance, humility and devotion to God. In assigning evil these educational and spiritually nurturing roles, the shaykh adopts ideas found also among the Mu'taziliss and the Sufis.

The first two types in Ibn Taymiyya's evil attribution typology formalize a dichotomy between the divine and human perspectives. However, the shaykh does not explicate this paradoxically in the spirit of Ibn 'Arabī. Instead, he attempts to resolve the attendant rational difficulties. His interpretation of Q. 4:78-9 in Hasana provides a prime example of this. Ibn Taymiyya denies

115 Fätiha, MF 14:24-8.

116 Fätị̂, MF 14:29-36. 
that there is a contradiction in these verses' claims that all is from God and that every evil thing is from the individual person afflicted. He resolves this most fully by locating the ultimate source of evil in the nonexistence or lack of the good deeds for which God created human beings. This lack cannot be attributed to the creative activity of God because a nonexistent has no agent, but God punishes people in whom this lack is found by creating evil deeds that preoccupy them from doing good deeds. However, there remains the question of why some people fall into a lack of good deeds. Here the shaykh implicitly acknowledges difficulty by switching back to the divine perspective and explaining that God chooses to employ some, but not others, in good deeds according to His mercy and wise purpose, just as He creates some to be stronger than others. Despite Ibn Taymiyya's denial of contradiction in Q. 4:78-9, his interpretation does not eliminate the contradiction in his doctrine between retribution on the one hand and God's mercy and wise purpose on the other.

A similar problem arises in Ibn Taymiyya's discussion of the basis for reward in Hasana. At some points, he grounds reward retributively in good deeds, but, at other points, he shifts this ground to God's unmerited grace in creating only blessings and good deeds. He then argues that God is the sole source of good and therefore the only worthy object of trust and worship. The same ideas are articulated more philosophically in Fätiha. The upshot is that piety and probably the concomitant injunction to give God the highest similitude nudge Ibn Taymiyya gently but firmly away from a retributive conception of good deeds. As a result, he limits retribution to evil deeds and grounds good deeds solely in God's grace and blessing. Perhaps as well the shaykh is simply working out the inherent logic of optimism. 
CHAPTER SIX

\section{THE JUSTICE OF GOD AND THE BEST OF ALL POSSIBLE WORLDS}

\section{Introduction}

The question of God's justice in rewarding and punishing humanity permeates the texts analyzed in the previous three chapters even though ' $a d l$, the Arabic term translated "justice," appears infrequently. However, Ibn Taymiyya does comment explicitly on the meaning of ${ }^{\prime} a d l$ and its opposite $z u l m$ (injustice) in a number of places, especially in Minhäj, Abü Dharr and 'ÁAdil. ${ }^{1}$ In these discussions of justice, Ibn Taymiyya maintains that all Muslims and people of other faiths agree that God is just and exonerated of injustice, but he notes that people have different understandings of these terms. ${ }^{2}$ He identifies three basic types of interpretation, which will be surveyed in the first part of this chapter. The first type is the Mu'tazili conception of God's justice as retributive. The second is the voluntaristic, Ash'arī notion of God's justice. The third type, Ibn Taymiyya's own position, defines God's justice as putting things in their proper places. The shaykh also devotes considerable attention in his justice discussions to the question of whether optimism endangers God's power and freedom. This will be taken up in the latter part of the chapter which also assesses the shaykh's few comments on al-Ghazâlī's claim that there is nothing in possibility more wonderful than this world. In what is probably the latest of these comments, Ibn Taymiyya affirms that this is the best of all possible worlds.

\footnotetext{
1 The main passages are 'Ádil, JR 121-6, 126-130; Minhāj, 1:134-141/1:33-4, 1:451-4/1:125-6, 2:304-313/214-5, 3:20-3/267-8; Jabr, MF 8:505-510; Abū Dharr, MF 18:137-156; and Nubuwwät, 143-7.

2 'Ádil, JR 121, 125; Minhäj, 1:133-4/1:32-3, 3:151/2:27; and Jabr, MF 8:505. Cf. Minhāj, 1:134/1:33, 1:453/1:125, where Ibn Taymiyya also says that no Sunnī Muslim states that God does bad or fails to keep obligations. 


\section{Ibn Taymiyya's Three-fold Typology on God's Justice ('adl)}

Ibn Taymiyya's discussions of the three basic types or ways of understanding God's justice in the Islamic tradition vary widely in completeness and length. At times, the shaykh focuses more on polemic against the Mu'tazilis or the Ash'arīs. At other times, he devotes more attention to explaining his own view. There is no one passage that sufficiently comprehends what is found in the others to serve as a basis for exposition. However, the views presented in the various texts are consistent, and this justifies a composite account for the sake of avoiding excessive repetition.

\section{Mu'tazilīs: God's Obligation to Retributive Justice}

Under the rubric of his first type, Ibn Taymiyya does not typically mention names of individual Mu'taziliss, and he frequently calls them simply Qadarīs. ${ }^{3}$ However, he does speak in Minhäj of the "moderns (muta'akbkbirün) of the Imāmīs" who follow the Mu'tazilīs in theology. ${ }^{4}$ This appellation is aimed chiefly at Twelver Shî̀ al al-Hillī, who wrote the anti-Sunnī tract that Minhāj refutes.

The shaykh also reviews basic elements of the Mu'tazili theodicy. God's justice is retributive in the sense that God metes out reward and punishment in due proportion for good and bad deeds, respectively. According to the shaykh, the Mu' tazili God does not will or create human acts of disobedience, iniquity and unbelief. Instead, humans create their own acts, and so God is just to punish those who disobey His command. ${ }^{5}$ If God were to create injustice directly in humans, He would be unjust to punish it, and if God were to chastise sins that $\mathrm{He}$ created, that would be unjust and undeserved harm. ${ }^{6}$ Moreover, Ibn Taymiyya reports, the Mu'tazili God must provide all possible help to His servants to carry out His commands, and He must help everyone equally. ${ }^{7}$ If God singled out one person over another for His mercy and bounty ( $f a d l)$, that would be unjust. ${ }^{8}$ The shaykh also mentions the Mu'tazili view that God must do what is best (așlab) for His servants, at

\footnotetext{
${ }^{3}$ Exceptions include Ibn Taymiyya’s mention of the early Mu'tazilī al-Nažām in ' $\bar{A} d i l$, JR 129 , and al-Jubbāi in the story of the three brothers quoted below.

${ }^{4}$ Minhāj, 1:134/1:33.

5 'Ádil, JR 123.

${ }^{6}$ Abü Dharr, MF 18:138, 152; and 'Ádil, JR 127. See also Abü Dharr, MF 18:145, for the definition of injustice as undeserved harm (idrär ghayr mustahiqq).

7 Abü Dharr, MF 18:138.

${ }^{8}$ Iräda, MF 8:92.
} 
least in matters of religion (Bașran Mu'tazilīs), or in worldly matters as well (Baghdādī Mu'tazilīs), ${ }^{9}$ and he cites the Mu'tazilī doctrine that God's reason for creating human beings was to benefit them and subject them to the possibility of earning reward. ${ }^{10}$ The main Mu'tazilī doctrine that Ibn Taymiyya fails to highlight is their doctrine that God must provide compensations ('iwad) to all creatures who suffer unjustly. ${ }^{11}$

Ibn Taymiyya rejects the Mu'tazili free-will theodicy outright because it posits humans creating their own acts. ${ }^{12}$ Also, drawing on arguments developed by the Ash'arī tradition, he takes the Mu'tazilīs to task for insisting that God adhere to human standards of retribution and even for turning God into a fool. As the shaykh sees it, the trouble begins when the Mu'taziliss ground God's justice in the rational discernment of moral value. They maintain that reason knows acts to be objectively good or bad by virtue of attributes inherent in the acts, and then they argue that God must be exonerated of acts that reason deems bad. Ibn Taymiyya counters that reason does not dictate that creatures and the Creator are subject to identical standards of good and bad. ${ }^{13} \mathrm{He}$ accuses the $\mathrm{Mu}^{\mathrm{c}}$ tazilīs of likening (tamthil) and assimilating (tashbih) God's acts to human acts and drawing an analogy from human acts to God's acts. In effect, he claims, the Mu'tazilīs set down a law for God, obligating Him to adhere to human standards of justice and forbidding Him from human notions of injustice, which, according to Ibn Taymiyya, violates God's complete unlikeness. ${ }^{14} \mathrm{He}$ explains that the $\mathrm{Mu}^{\text {' }}$ tazilīs and like-minded Shīîs, such as al-Hillī, apply their "law" polemically to the God of the Ash'arīs, Who is by definition outside the sphere of human morality. The Ash'arī God does not meet the Mu'tazilì standard of justice, and so, the Mu'tazilīs conclude, this God commits bad deeds and fails to fulfill obligations. ${ }^{15}$ Ibn Taymiyya complains that the Mu'tazilis "propounded similitudes (amthāl) for God but did not give Him the highest similitude." ${ }^{16}$ It is not

9 Minhäj, 3:198/2:39; and Iräda, MF 8:92.

10 'Ádil, JR 128; Jabr, MF 8:506; and Minhäj, 3:152-3/2:27-8.

${ }_{11}$ For compensation in the thought of 'Abd al-Jabbār, see Heemskerk, Suffering in Mutazilite Theology, 142-191. Cf. Schmidtke, Theology, 117-124.

${ }_{12}$ Abü Dharr, MF 18:138, 148; and 'Ádil, JR 129.

13 Abū Dharr, MF 18:147.

14 Minhāj, 1:447-8/1:124, 3:39-40/1:272, 3:153/2:28; Jabr, MF 8:505-6; Abü Dharr, MF 18:138, 147; Tahsin al-'aql, MF 8:431-2; and 'Ádil, JR 128. For 'Abd al-Jabbār's univocal

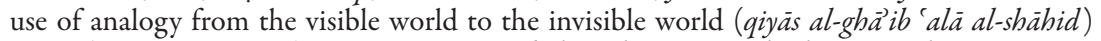
in God's acts, see Daniel Gimaret, Théories de l'acte humain en théologie musulmane, 281-3; and Heemskerk, Suffering in Mutazilite Theology, 112-3.

${ }_{15}$ Minhäj, 1:453-4/1:125-6.

16 Abū Dharr, MF 18:138. 
just a matter of the Mu'tazilis likening God to creatures. It is also that when they do they arrive at an inadequate view of God.

To explain further how he believes analogy and assimilation fail the Mu'tazilis, Ibn Taymiyya juxtaposes the Muslim obligation to command the right and forbid the wrong with the Mu'tazili view of libertarian freedom. ${ }^{17}$ In Jabr he gives the following argument: If someone were able to stop others from being unjust to one another but did not prevent them, he himself would be unjust. Implied here is that God should stop injustice if indeed $\mathrm{He}$ is subject to human standards. In reply the Mu'tazilis assert that God gives humans free choice and provides opportunity for reward if they obey and punishment if they do not. If God were to force someone not to do something, the opportunity for reward provided by obligation would fall away. Ibn Taymiyya responds that most people would reply that someone who acts like this-knowing full well that his servants will not obey his command-is neither wise nor just. Such behavior would be praiseworthy only in someone who did not know what was going to happen or could not prevent it. God however is all-powerful and knows future events, and someone who can prevent injustice must do so by force $(i l j \vec{a}) .{ }^{18}$ Ibn Taymiyya mocks the Mu'tazilīs in Minhaj for implying that God creates power in humans by which they can lie and commit iniquity and injustice, knowing full well that they will commit such acts. This implies even that God helps them to commit these deeds. The shaykh compares this to one person giving another a sword to fight unbelievers knowing full well that he will misuse it to kill a prophet. The shaykh says that this is foolish on the human level and that God as well is exonerated of this. He adds that God's acts are judged differently from ours and that $\mathrm{He}$ has a wise purpose in what He creates. ${ }^{19}$

In Minhäj Ibn Taymiyya cites the famous Ash'arī story of the three brothers to show that the Mu'tazili doctrine of the best (așlab) falls into contradiction because it is based on assimilation of God to creatures. Rosalind Gwynne has shown that Fakhr al-Dīn al-Rāzī was probably the first to link this story to al-Ash'arī’s break with his Mu'tazilī master Abū 'Alī al-Jubbā'ī

${ }^{17}$ For an extensive discussion of this obligation in the Islamic tradition, see Michael Cook, Commanding Right and Forbidding Wrong in Islamic Thought (Cambridge, UK: Cambridge University Press, 2000).

${ }_{18} \mathrm{Jabr}$, MF 8:506.

19 Minhāj, 3:220-1/2:44. For additional arguments of this sort, see Minhäj, 3:151-3/2:27-8: it would be foolish for a man to give his son money if he knew the son was going to use it to buy poison to eat; and ' $\bar{A} d i l$, JR 128: it would be unjust for a master to let his slaves commit injustice if he could stop it. Cf. Minhäj, 2:312-3/1:215. 
(d. 303/916). ${ }^{20}$ Be that as it may, Ibn Taymiyya simply accepts the account as historical:

[Al-Ash'arī] said to [al-Jubbāīi]: When God created three brothers, one of them died young, and the other two reached the age of accountability. One of the [latter] two believed, and the other disbelieved. [God] brought the believer into Paradise and raised his rank. He brought the young one into Paradise and made his level below [the other brother]. The young one said to Him, "O Lord! Raise me to the rank of my brother." He said, "You are not like him. He believed and committed righteous deeds. You are young, and you did not commit the deeds he did." He said, "O Lord! You made me die. If you had kept me [alive], I would have done the like of his deeds." He said, "I did what was to your benefit (maslaha) because I knew that if you had reached the age of accountability you would have disbelieved. Therefore, I carried you away to death." Then, the third [brother] cried out from the depths of the Fire, and he said, "O Lord! Why did you not carry me away to death before reaching the age of accountability as you carried my young brother away to death? For this would have been of benefit to me also." It is said that when this was brought against [al-Jubbāīi], he stopped. This is because [the Mu'tazilīs] obligate Him to be just between two likes and to do what is best (aslab) to each one of them. Here, He did what was best, according to them, to one of the two but not to the other. This is not the place to elaborate on this. If the matter is like this, their assimilation of God to His creatures is vain. ${ }^{21}$

In addition to showing the absurdity to which he believes the Mu'tazilī sense of God's rigorous fairness leads, Ibn Taymiyya in Minhāj also explains his own view that God is not unjust to single out some for special blessings over others. God bestows the special grace of guidance upon some people so that they believe while upon others He does not. Likewise, He gives some more knowledge, health, strength and beauty than others. To support his point, the shaykh quotes the quranic verse: "Is it they who divide out the mercy of your Lord? It is We who divide out between them their livelihood in this world, and We have raised some of them above others in ranks so that some may take others into subjection" (Q. 32:43). ${ }^{22}$

In Minhāj the shaykh also argues that an odious consequence of al-Hillī's $\mathrm{Mu}$ 'tazilism is that God cannot be thanked because $\mathrm{He}$ is doing no more than fulfilling His obligations. This argument rests on the presupposition that gratitude is due only for blessings that exceed obligations. God, in al-Hillīs

${ }^{20}$ Rosalind W. Gwynne, "Al-Jubbā'ī, al-Ash' arī and the Three Brothers: The Uses of Fiction," The Muslim World 75 (July-Oct. 1985): 132-161.

${ }^{21}$ Minhāj, 3:198-9/2:39.

${ }^{22}$ Minhāj, 1:138/1:34. 
view, is obligated to provide both worldly and religious blessings. ${ }^{23}$ Moreover, God cannot make someone a believer, and, so, He cannot be thanked for that either. God's blessings in the hereafter consist in obligatory recompense just as an employer must pay an employee his wage or a debtor must pay off his debt. Thus, all is obligation for God, and He is not worthy of thanks for anything. Additionally, Ibn Taymiyya reads al-Hillī to say that humans are not worthy of praise, thanks or blame if God makes them do good or evil. Conversely, one cannot say that God is blessing or testing when human authorities act justly or unjustly, respectively, because God is not controlling their actions. This, the shaykh argues, undermines the proper attitude of thankfulness both to God and to other people that befits believers in all circumstances. Rather, the shaykh asserts, human beings have been naturally constituted to praise someone who does good and to blame one who does evil even if these acts are determined and created by God. God makes one person deserving of praise and reward and another deserving of punishment and blame according to His wise purpose. ${ }^{24}$

In sum Ibn Taymiyya is unsympathetic to the sober Mu'tazili free-will theodicy in which God treats human beings with rigorous equality as they freely choose their response to God's command and earn their just deserts. He attacks the Mu'tazilīs both for obligating God to act according to a retributive ethic and for misconceiving the divine economy in such a way that makes God look foolish and undermines thankfulness to Him. ${ }^{25}$

\section{Ash' aris: God's Voluntaristic Justice}

In the second of Ibn Taymiyya's three types, God's justice is voluntaristic. Whatever God wills is just by virtue of the fact that it is God who wills it. Ibn Taymiyya attributes this view to the Jahmis, the followers of Jahm b. Șafwān, al-Ash'arī and the Ash'arīs including al-Bāqillānī and al-Juwaynī, the Hanbalīs Abū Yálā, Ibn al-Zāghūnī and Ibn al-Jawzī, the Mālikī Abū al-Walīd al-Bājī (d. 474/1081), and other members of all four of the Sunnī schools of law. ${ }^{26} \mathrm{He}$ also attributes it to the "moderns (muta'akbkhirün) of the Jahmīs" ${ }^{27}$ and "the moderns among the Kalām theologians who establish

\footnotetext{
23 On this view in al-Hillī's thought, see Schmidtke, Theology, 109-115.

${ }^{24}$ Minhäj, 3:131-7/2:22-4.

25 Most of the arguments above may be found in Ash'arī Kalām handbooks. See for example al-Shahrastānī, Kitāb nihāyatu, 397-411 (Arabic), 126-131 (English).

${ }_{26}$ Minhäj, 3:20/1:267; and 'Ádil, JR 122-3, 127.

$27 \mathrm{Jabr}, \mathrm{MF}$ 8:506.
} 
determination," both of which probably refer to Fakhr al-Dīn al-Rāzì and possibly al-Āmidī. ${ }^{28}$

In the Ash'ari view, according to the shaykh, injustice is inherently impossible for God in the same way that it is impossible to combine two contradictories or put one body in two places at once. God would be just to do anything imaginable whose existence is possible, and $\mathrm{He}$ is not under external obligation of any kind. God would not be unjust to chastise the obedient or reward the disobedient. He may punish the children of unbelievers and the insane even if they have not sinned. He would not be unjust to punish someone even for his color or height. Ibn Taymiyya cites two Ash'arī arguments for this doctrine. First, injustice means acting freely in someone else's property. Since everything is God's property, it is by definition impossible for Him to be unjust. Second, injustice means opposing a command that must be obeyed. Since God is not subject to the command of any other, injustice cannot be ascribed to God. ${ }^{29}$

With respect to the first argument, Ibn Taymiyya rejects defining justice as freely acting in someone else's property. He counters, "A human being may rightly act freely in the property of another and not be unjust, and he may wrongly act freely in his [own] property and be unjust. Injustice of the servant against himself is frequent in the Qur'an." ${ }^{30}$ The shaykh also traces the Ash'ari definition of injustice to an alleged misunderstanding. He observes that Iyās b. Mu'āwiyya (d. 122/740) is reported to have said, "I have not disputed with anyone with my whole mind except the Qadarīs. I said to them, 'What is injustice?' They said, 'That you take what is not yours', or 'That you act freely in what is not yours'. I said, 'To God belongs everything."' 31 Iyās, the shaykh explains, did not intend to define God's justice. He sought only to show that the Qadarīs were wrong and to avoid going into further details. ${ }^{32}$

With respect to the second argument, which is based on the premise that God is not subject to commands, Ibn Taymiyya counters that God has in fact subjected Himself to His own writing and forbidding: "God-Glory be

28 Abü Dharr, MF 18:138.

29 Minhāj, 1:134/1:33, 1:452/1:125, 2:305-6/1:214-5, 3:20-2/1:267-8, 3:40/1:272; 'Ádil, JR 121, 125, 127; Jabr, MF 8:506-7; Abū Dharr, MF 18:139, 152; and Nubuwwät, 143-5.

30 Abü Dharr, MF 18:145.

31 The version of this dictum translated here is that found in Abu Dharr, MF 18:139. It is also found with slight variations in Minhäj, 1:304-5/1:214, 3:22/1:268, and in 'Ádil, JR 122.

${ }^{32}$ Abū Dharr, MF 18:139-140. 
to Him - has written mercy for Himself and forbidden injustice to Himself. He does not act in opposition to what He has written, and He does not do what He has forbidden." ${ }^{33}$ All well and good, but the God of Ash'arism may not necessarily be as capricious as Ibn Taymiyya makes Him out to be. The shaykh also reports the Ash'arī view that God will not do everything that is permissible for Him because God has said that He will not and because this information corresponds to His knowledge of what He will and will not do. God will not in fact punish children without sin and bring unbelievers into Paradise even though it would not be unjust of Him to do so. God will keep His promises given in revelation. ${ }^{34}$

Ibn Taymiyya does not always explain why he finds this Ash'arī qualification inadequate to guarantee God's reliability. ${ }^{35}$ In Nubuwwät, however, he argues that a God who has arbitrary choice in possibility, if not in actuality, cannot be known to be reliable in the information that He gives. He retorts that the Ash'arīs allow that God could send anyone with whatever message He wills, even someone who commits grave sins. ${ }^{36}$ Ibn Taymiyya then turns the Ash 'arīs' denial of God's purposive activity against them to undermine their foundations for prophetic reliability. He cites al-Ash'arī, al-Bāqillānī, Ibn Fūrak and the Hanbalī Abū Ya 'à as arguing that a God who is powerful must confirm the truthfulness of His prophets and that this can be done only through miracles. The shaykh says that this contradicts the Ash'ari contention that God may do whatever He wills. Moreover, God cannot establish a miracle as a sign of the truthfulness of a messenger if He does not do one thing on account of another, that is, if He does not act for purposes. Ibn Taymiyya reports as well that al-Juwayni adopted a different strategy, claiming that knowledge of the truthfulness of prophets to whom God gives a miracle is necessary. The shaykh replies that this argument works only if it is known

\footnotetext{
${ }^{33}$ Abü Dharr, MF 18:145.

${ }^{34}$ Abu Dharr, MF 18:148; Nubuwwāt, 143; and Minhāj, 1:451-2/1:125. The basics of this view are found in al-Ash'arîs Kitäb al-luma'. In response to the question, "Is it for God-Exalted is He-to inflict pain on children in the hereafter?" al-Ash'arī writes, "It is for God [to do] that, and He would be just if He did that. Similarly, whenever He inflicts an infinite punishment for a finite crime, subjects some living beings to others, blesses some apart from others, and creates them knowing that they will disbelieve, all of this is justice on His part. It would not be bad on the part of God if He were to bring them forth in painful chastisement and make it perpetual. It would not be bad on His part to chastise the believers and bring the unbelievers into Paradise. We only say that $\mathrm{He}$ will not do that because $\mathrm{He}$ has informed us that He will punish the unbelievers, and it is not permissible for Him to lie in His informing." This translation has been adapted from that of McCarthy in The Theology of al-Ash' arī, 71 (Arabic) and 169 (trans.).

${ }_{35}$ As in Abü Dharr, MF 18:148; and Minhäj, 1:451-2/1:125.

${ }^{36}$ Nubuwwāt, 145-6.
} 
that God is one who does things for wise purposes. Otherwise, there is no way of knowing that God has done something to indicate something else. It must be known necessarily that God does things for wise purposes before one can recognize necessarily that God confirms His messengers through miracles. ${ }^{37}$ In Nubuwwät Ibn Taymiyya himself establishes the reliability of prophets on the basis of necessary knowledge that God acts for wise purposes. God's wise purpose, justice and mercy are known by reason. ${ }^{38}$ Rational proof of God's wise purpose is found in the dazzling divine wisdom that is evident in all created things, as for example in the perfect placement of the body parts. ${ }^{39}$ God must act according to His wise purpose, and, "His wise purpose necessitates that He make the truthfulness of the prophets obvious and support them." ${ }^{40}$

In short Ibn Taymiyya's critique of the Ash'arīs' view of justice reduces to upbraiding them for denying that God's justice entails some kind of rationality. A capricious God who could so radically violate the order of retribution as to punish believers for their belief or make liars into prophets and still be called just cannot by His very nature establish a relationship with humankind based on promise and trust.

Much as was observed when discussing Shams in Chapter Three, Ibn Taymiyya's polemic here against the Mu'tazilīs and the Ash'arīs appears contradictory. On the one hand, he attacks the $\mathrm{Mu}^{\prime}$ tazilis for applying analogical reasoning to God and assimilating God to creatures. On the other, he appears to fall into this very error when criticizing both the Mu'taziliss for making God foolish and the Ash'arīs for rendering God capricious. Unfortunately, Ibn Taymiyya does not elaborate his theological principles adequately enough

${ }^{37}$ Nubuwwāt, 148-9, 361-2, 371-3.

${ }^{38}$ Nubuwwāt, 349-353, 361.

39 Nubuwwāt, 356-7.

40 Nubuwwāt, 349. For this point, see also Hasana, MF 14:271; and Minhäj, 3:91-9/2:124, 3:226-8/2:46. In Minhäj, 3:97/2:12, Ibn Taymiyya adds that it would be an attribute of imperfection for God to confirm a liar. For more on Ash'arī difficulties in prophecy, see Gardet, Dieu et la destinée de l'homme, 200-1. Also, Ibn Taymiyya, Nubuwwät, 364-5, notes that al-Ghazālĩ saw the difficulties in traditional Ash'arī views and turned to the view of the philosophers that prophecy is a genus of dreams (manamant), and he reports that al-Rāzì vacillates concerning prophecy between the Ash'arīs and the philosophers. Ceylan, Theology and Tafsìr, 167-172, also recounts al-Rāzī's difficulties on prophecy. Frank Griffel, "Al-Gazālīs Concept of Prophecy: The Introduction of Avicennan Psychology Into Ašcarite Theology," Arabic Sciences and Philosophy 14 (2004): 101-144, explains that al-Ghazālī and al-Rāzī recognize difficulties in the early Ash'arī view that miracles authenticate prophets and so ground evaluation of prophetic claims psychologically in necessary knowledge of what constitutes prophetic truthfulness. See now Shihadeh, Teleological Ethics, 129-142, for a more comprehensive discussion of al-Rāzìs thought on the authentication of prophetic claims. 
in his justice texts to make full sense of his argumentation, but the contradiction may be resolved by reference to his juristic methodology pertaining to theological matters surveyed in Chapter One. On the one hand, as will also become clear below, God must be envisioned according to the highest humanly imaginable perfection on both rational and quranic grounds. On the other, God's perfection requires that He be wholly unlike creatures and subject to no analogy. Thus, the shaykh's discourse on God's justice does not purport to inform about its modality but simply how to speak of God's justice with the highest praise.

\section{Ibn Taymiyya: God's Justice as Putting Things in their Places}

The third type in Ibn Taymiyya's justice typology sets out his own view, and here his optimism becomes readily apparent. He sometimes begins by defining injustice rather than justice. Injustice $(z u l m)$ is putting something in other than its place. He sometimes traces this definition to the linguist Abū Bakr b. al-Anbārī (328/940), and he attributes this view to "many of the Sunnīs, hadith scholars and people of rational thought (abl al-nuzār)."141 Beyond this, he gives no names, but justice defined as putting things in their places is common in the tradition. Al-Ghazālī, for example, defines justice in this fashion when outlining the wise placement of the body parts as a sign of the orderliness of God's creation in al-Maqșad al-asna $\bar{a}^{42}$ For al-Māturīdī as well, justice is putting a thing in its place, and al-Shahrastānī says that this is orthodox doctrine. ${ }^{43}$

Ibn Taymiyya does not clearly define what it means to put things in their places. In a context beyond his justice typologies, he characterizes God's justice as "beneficence (ihsānn) to His creatures." ${ }^{44}$ This gives no specific content to God's justice except to identify it with God's goodness. In his justice typologies, however, he often gives justice connotations of retribution. Following is one of his more extended definitions, which comes from 'A $\bar{A} d i l$ :

${ }^{41} \mathrm{Jabr}$, MF 8:507. Cf. Minhäj, 1:139/1:34; and Abū Dharr, MF 18:145. For the connection to Ibn al-Anbārī, see 'Ádil, JR 124, 129.

${ }^{42}$ Al-Ghazālī, Al-Maqșad al-asnā fì sharh má ānì asmäà Allāh al-husnā, ed. Fadlou A. Shehadi (Beirut: Dar el-Machreq, 1982), 105-9 (on God's name al-' Adl). See Frank, Creation and the Cosmic System, 64-6, for further analysis of al-Ghazālī on God's justice.

${ }_{33}$ Pessagno, "The uses of Evil in Maturidian Thought," 68-9; Abū Manșūr al-Māturīdī, Kitāb al-tawhīd, ed. Fath Allāh Khulayf (Alexandria: Dār al-jāmi'āt al-miṣriyya, n.d.), 97; Al-Shahrastānī, Al-Milal wa al-nihal, 37.

${ }_{44}$ Qudra, MF 8:31. 
Injustice is putting something in other than its place (wad' al-shay' fì ghayr mawdi ihi). Justice is putting everything in its place. He-Glory be to Him-is a wise arbiter and just, putting things in their places. He does not put anything except in its place, which corresponds to it and which wise purpose and justice require. He does not differentiate between two likes, and $\mathrm{He}$ does not equate two different things. He punishes only whoever deserves punishment and puts [the punishment] in its place on account of the wise purpose and justice in that. As for the people of righteousness and piety $($ taqwa $)$, He does not punish them at all. ${ }^{45}$

Apart from the tautology of defining "justice" as putting something in its place as "wise purpose and justice require," the text carries an appeal to an intuitive sense of retribution. Elsewhere, the shaykh claims that it is known by the natural constitution that it is not permissible for God in His justice, wisdom and mercy to punish those who do good works and raise the iniquitous to the highest rank. ${ }^{46}$ Similarly, he quotes, "Whoever does deeds of righteousness and is a believer will not fear injustice or curtailment (hadman)" (Q. 20:112), and he explains that "curtailment" is reducing one's good deeds, and "injustice" is making one responsible for the evil deeds of another. Only those who sin will be punished in the hereafter even though God may also pardon some. ${ }^{47}$ Other verses he quotes along these lines include: "Indeed, God is not unjust to so much as the weight of an ant" (Q. 4:40); "That no one burdened bear the burden of another, and that the human has only that for which he has made an effort" (Q. 53:38-9); and, "Whoever does good equal to the weight of a small ant will see it, and whoever does evil equal to the weight of a small ant will see it" (Q. 99:7-8). ${ }^{48}$ These last two verses suggest a rigorous standard of retribution. However, Ibn Taymiyya adds that God is also merciful to many people without regard to their deeds and that profit may accrue to a person from God's grace and mercy as well as from the invocation and deeds of others. ${ }^{49}$

The upshot of these comments is that justice for Ibn Taymiyya means putting reward and punishment in their proper places, where the "place" of something is not clearly defined. For the most part, however, it appears

45 'A dil, JR 123-4.

46 Nubuwwāt, 145. Cf. 'Ádil, JR 125, 128; and Minhāj, 1:139/1:34. Ibn Taymiyya, Nubuwwàt, 42-3, also explains that God grants recompense in this world in accord with wise purpose and benefit and that God punishes each disobedient people according to His wise purpose and what is fitting for them.

$47 \mathrm{Jabr}$, MF 8:507; Abū Dharr, MF 18:141-4, 146; and Nubuwwāt, 144.

48 'Ádil, JR 126; Jabr, MF 8:507; Abü Dharr, 18:142; and Minhäj, 1:135-8/1:33-4. These references include additional quranic verses of this kind.

49 'A dil, JR 126; and Abü Dharr, 18:142-3. 
that the wicked are punished while the righteous are not. Yet, retribution is not absolute and some other rationality-that of God's mercy-sometimes comes into play such that punishment for bad deeds does not always ensue. Even though Ibn Taymiyya does not specify the rationality to which God's justice conforms, he optimistically believes that human beings will recognize it when they see it.

Now in view of Ibn Taymiyya's conviction that God creates all things, it might be asked how some people become fitting places for punishment. How is it that human beings end up in the quandary of needing to be punished? The shaykh's justice passages generally do not broach this question, but he does attribute God's creation of evil deeds to an unspecified divine wise purpose in 'ÁAdl. ' $\bar{A} d i l$ opens with two consecutive versions of his justice typology and then shifts to a defense of God against the charge that $\mathrm{He}$ commits bad and evil deeds. The wordy argument focuses very little on the causes of evil, but it extols the goodness of what God does at length. Only the central points of this defense will be given here.

To begin, Ibn Taymiyya explains that God makes humans commit evil and unjust acts for a wise purpose. He does not explain what this wise purpose is but observes instead that this is a matter of God justly putting things in their places. ${ }^{50}$ The shaykh supports his point by noting that human artisans do the same thing in placing defective raw materials in places properly befitting them:

When the artisan takes a crooked board, a broken stone and an imperfect brick, he puts them in a place befitting them and becoming of them. From him this is just, upright and correct. He is praiseworthy even if there is a crook and a fault in them by virtue of which they are blameworthy. Whoever takes disgusting things (khabäith) and puts them in the place that befits them, this is wise and just. Foolishness and injustice are only that he places them in other than their place. Whoever places a turban on the head and sandals on the feet has placed each thing in its place. He has not been unjust to the sandals since this is their place becoming of them. Thus, He-Glory be to Him-places a thing only in its place. This is only just, and He does only good. He is only beneficent, liberal and merciful. ${ }^{51}$

${ }^{50}$ ' $\bar{A} d i l$, JR 130.

51 ' $\bar{A} d i l$, JR 130. Ormbsy, Theodicy, 228, translates an almost identical passage from a brief treatise on evil by the Ottoman scholar Ibn Kamāl Pasha (d. 940/1534), "Fĩ bayān alhikma li-'adam nisbat al-sharr ilayhi ta ālāa," in Rasā̄il Ibn Kamāl (Istanbul: Maṭaba'at Iqdām, 1316/1898-9), 1:125-130 (passage on 126). In view of the fact that Ibn Taymiyya's and Ibn Kamāl's texts are otherwise dissimilar, it seems likely that Ibn Kamāl is not dependent on Ibn Taymiyya for this passage but that both are dependent on a common earlier source. 
Following this affirmation of the justice in everything that God does, Ibn Taymiyya states that God in His religious, legislative will has commanded what He loves and what is best and most beneficial and that what God has created is better than what He has not created. God creates only good, which is defined as "that whose existence is better than its nonexistence."52 God does not will and create evil, which is "the existence of everything whose nonexistence is better than its existence." 53 The shaykh explains that the terms good (khayr) and evil (sharr) are used most commonly in their comparative senses: "Good is what is better than something else, and evil is what is more evil than something else. Good and evil are in degrees (darajāt). ${ }^{54} \mathrm{He}$ then notes that the evil that God creates is good by virtue of God's wise purpose and that its existence in general is better than its nonexistence. Created evil is only perceived to be evil when compared to something else, and it is harmful only to some people. 55

Ibn Taymiyya affirms at some length in ' $\bar{A} d i l$ that God is just and wise in that He chastises and punishes human beings only for the sins that they commit. The shaykh explains that God does not recompense, chastise, destroy, withdraw blessing and take vengeance except on account of sins and evil deeds. He adds, moreover, that the aim of God's chastisement in some cases is to bring about humility and repentance, as in the verse, "Indeed We seized them with chastisement, but they did not abase themselves before their Lord, and they were not humble" (Q. 23:76). ${ }^{56}$ The shaykh leaves off discussion of God's retribution without addressing the fundamental reasons for human disobedience. Instead, he states that his objective is to emphasize that God always does what is best: "The point here is that the existence of everything that the Lord does and creates is better than its nonexistence. It also is better than something else, that is, [better] than an existent other than it that could be supposed to be existent instead of it." ${ }^{57} \mathrm{~A}$ few lines later in 'Ádil, Ibn Taymiyya reaches a climax in his argument:

To the Lord-Exalted is $\mathrm{He}-$ is the highest similitude (cf. Q. 16:60). He is higher than any other, having a greater right to praise and laudation than everything other than $\mathrm{Him}$, most worthy of the attributes of perfection and the farthest from the attributes of imperfection. It is impossible that the creature

\footnotetext{
'Ádil, JR 130-1 (quote on 131).

'Ádil, JR 131.

'Ádil, JR 133.

'Ādil, JR 134.

'Ádil, JR 134-6.

'Ādil, JR 136.
} 
be qualified with a perfection in which there is no imperfection. The Lord is qualified only with the perfection in which there is no imperfection. When He commands His servant to do the finest (al-ahsan) and the best (al-khayr), it is impossible that He Himself do [anything] but the finest and the best. Doing the finest and the best is praised and is a perfection in which there is no imperfection. He has a greater right to praise and perfection in which there is no imperfection than any other. ${ }^{58}$

In this passage, Ibn Taymiyya grounds God's doing the best both in the quranic injunction to ascribe the highest similitude to God and in God's rational a fortiori right to praise and the highest humanly conceivable perfection. Moreover, he argues, if God commands human beings to do what is best, it is impossible that God Himself should do anything less. That God does what is best does not arise from empirical consideration of the actual world; it is instead rooted in a priori convictions-whether scriptural or rational-about what the perfection of God entails.

\section{Ibn Taymiyya on God's Power and al-Ghazälì's Best of All Possible Worlds}

A major difficulty with Ibn Taymiyya's optimism, with the conviction that God does only what is best, is that it endangers God's power. The necessity that God in His perfection and justice create the best possible world easily implies that God could not have created any world other than this. While not openly admitting the problem, the shaykh does in his various three-fold justice typologies expend considerable effort defending God's power and freedom to do other than what God does in fact do. To make the point, he insists that God has power to commit injustice even if God does not actually do so: "[God] has put everything in its place despite His power to do the opposite of that. He-Glory be to Him-acts by His free choice and His will. He has a right to praise and laudation for being just and not unjust." 59 Whereas the Ash' arīs say that injustice is inherently impossible for God, Ibn

58 'A $d i l$, JR 136. Following these rational arguments, the shaykh also supports his claim that God necessarily does what is best with several quranic references, including, "In Your hand is the good (khayr). Truly, You are Powerful over everything" (Q. 3:26), "God has sent down the best discourse (absan al-hadith)" (Q. 39:23), and "Who made good everything He created" (Q. 32:7). A little later, he reasserts that it is impossible for the creature to be more perfect than the Creator, and thus, "It is necessary that He will by means of [His will] what is more worthy, better and preferable" (141).

59 'A $A d i l$, JR 129. 
Taymiyya argues that divine injustice is possible (maqdīr and mumkin). God could do injustice but chooses not to, and this makes Him praiseworthy because praise is due only to one who chooses not to do injustice, not to one for whom it is inherently impossible. ${ }^{60}$

In another strategy to avoid the necessitarianism of optimism and retain God's freedom, Ibn Taymiyya speaks of God's self-obligation not to commit injustice. He bases this on a divine saying in the collection of Muslim, "O My servants! I have forbidden injustice to Myself." ${ }^{61}$ According to the shaykh, this hadith necessarily implies that injustice is possible for God. If God has forbidden something to Himself, it must have been possible beforehand. Otherwise, the hadith would mean, "I have informed about Myself that what is not possible is not from Me." ${ }^{2}$ This is a useless interpretation in the shaykh's opinion and does not elicit praise. ${ }^{63}$

Ibn Taymiyya also demonstrates concern to uphold God's power and freedom in three comments on the dictum, "There is nothing in possibility more wonderful than what is (laysa fí al-imkān abda mimmà kān)." This saying goes back to the theosophical "Kitāb al-tawhīd wa al-tawakkul" of

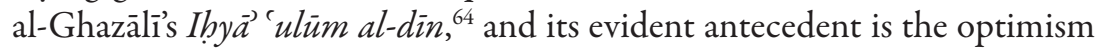
of Ibn Sināss doctrine of providence. In Theodicy in Islamic Thought, Eric Ormsby provides a history and analysis of the controversy that ensued from this dictum, and a brief look at Ormsby's study is relevant here in order to assess the historical significance of Ibn Taymiyya's comments. ${ }^{65}$

After examining the origins of this dictum in al-Ghazālì's writings, Ormsby's second chapter surveys its various commentators from the time of al-Ghazāil down to the thirteenth/nineteenth century. The relatively few scholars who commented on the dictum up to the mid-eighth/fourteenth century usually objected to it on the grounds that, in addition to dabbling too much in Sufism and philosophy, al-Ghazālī had limited God's power. In this earlier period, the only figure that Ormsby cites as approving the saying is

${ }^{60}$ Minhāj, 1:135/1:33; and Abū Dharr, MF 18:146.

${ }_{61}^{61}$ Muslim, 4674, Al-Birr wa al-ṣila wa al-ādāb, Taḥrīm al-ẓulm.

${ }^{62}$ Abü Dharr, MF 18:144.

${ }^{63}$ Abü Dharr, MF 18:144; Minhāj, 1:135-7/1:33, 1:451-3/1:125; and Jabr, MF 8:509.

${ }^{64}$ In Iḩya ' 'ulüm al-dìn, 4:258, al-Ghazālī writes, "There is nothing in possibility fundamentally better (ahsan) than [what God divides out], nor more complete, nor more perfect." In

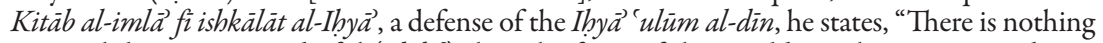
in possibility more wonderful $(a b d a)$ than the form of this world, nor better arranged, nor more perfectly (akmal) made" (in Mulhaq al-Ihy $\vec{a}$ printed with Ihy $\vec{a}$ ' ulüm al-dìn, 5:13-41, at 35). For detailed discussion of these texts, see Ormsby, Theodicy, 37-81.

${ }_{65}$ Ittihädiyyin, MF 2:213; Kasb, MF 8:399; and 'Ädil, JR 142. 
Ibn 'Arabī. From the mid-eighth/fourteenth century onward, however, there was a shift toward accepting the dictum, and in the ninth/fifteen century it was subjected to major debate.

In the third through fifth chapters Ormsby surveys the basic objections to al-Ghazālī's statement-it impinges on God's power to do anything that He might wish; it makes creation a natural necessity (the error of the philosophers); and it obligates God to do the best (asläb) (the error of the Mu'tazilīs) — and he explains how al-Ghazālìns defenders overcame these objections. Al-Ghazâlī's defenders argued that even though the world is perfect and just at every moment of its existence, it is also contingent. Things could be other than what they are, but God's wisdom determines what will and will not be. Ormsby points out that the challenge of theodicy "is to assert the necessary rightness of things as they are, but to do so in a way that they are seen as proceeding from God's will, wisdom, and power, and not from a necessity of His nature." ${ }^{16} \mathrm{He}$ concludes that necessity finally rests in God's wisdom in the theodicy of al-Ghazāli and his defenders. ${ }^{67}$

Ormsby does not include Ibn Taymiyya as a participant in the above debate, and the brevity of the shaykh's three comments on al-Ghazâli's aphorism indicates that it did not concern him greatly. ${ }^{68}$ Nonetheless, his contribution to the dispute is not insignificant. In two of his comments on al-Ghazālī’s dictum, Ibn Taymiyya does not refer to al-Ghazālī by name. One occurs in a context where he accuses Ibn 'Arabī of limiting God's power to the power to create only what actually exists. Here, he adds in passing that most people deny the dictum, and it is clear that he does so as well. ${ }^{69}$ The second comment rejects the dictum as of a piece with the philosophers' ideas that the Creator is necessitating in His essence and that what exists is the only thing possible. ${ }^{70}$ Ibn Taymiyya gives al-Ghazālīs dictum closer attention

${ }^{66}$ Ormsby, Theodicy, 264.

${ }^{67}$ Ormsby, Theodicy, 259-264. Ormsby's analysis focuses on the possibility that God can do other than what He does, something that Ibn Taymiyya also affirms in his discussions of justice. However, al-Ghazālī and his defenders do not appear to understand wisdom in the causal and purposive sense of Ibn Taymiyya but rather as God's eternal knowledge and decree. Ormsby does not address this question directly except to note that al-Ghazālîs detractor alSijilmāsī al-Lamațī (d. 1156/1743) raises the problem of causality in wisdom only to have it dismissed by al-Ghazālìs later defenders as unworthy of attention (204-7).

${ }^{6}$ In passing Ormsby, Theodicy, 47, mentions with reference to Bell, Love Theory, 69ff., that Ibn Taymiyya took the Ash'arīs to task for denying God's wisdom, but he does not examine the shaykh's critique.

69 Ittihädiyyin, MF 2:213.

${ }^{70}$ Kasb, MF 8:399. 
at the end of ' $\bar{A} d i l$. This remark is probably the latest of the three because this treatise dates from the last two years of his life. He explains that some scholars reject the saying in order to protect God's power, and he agrees that God certainly has power to create other than this world. However, he notes that there is another way to read the dictum:

It could mean that no better (absan) than this [world] or no more perfect (akmal) than this is possible (yumkin). This is not a defamation of power. Rather, it has established His power [to do] other than what He has done. However, it says, "What He has done is better and more perfect than what $\mathrm{He}$ has not done." This ascribes to Him-Glory be to Him-generosity, liberality and beneficence. He-Glory be to Him-is the most generous. No more generous (akram) [being] than He can be conceived. ${ }^{71}$

Thus, Ibn Taymiyya accepts al-Ghazālīs statement on the condition that it is understood that God could have created other than He did. However, what God did create is the best of all possible worlds because He is the most perfect and generous being imaginable. With this, Ibn Taymiyya becomes one of the earliest scholars after Ibn 'Arabì to accept al-Ghazālī's dictum before it became widely accepted from the mid-eighth/fourteenth century onward. The degree to which Ibn Taymiyya may have contributed to its eventual approval would perhaps be more than one could ascertain.

\section{Conclusion}

In various passages dealing with justice (' $a d l$ ) Ibn Taymiyya rejects the Mu'tazilī theodicy for subjecting God to an external and un-praiseworthy standard of strict retributive justice, and he denounces the Ash'arīs for rendering God utterly unreliable. Ibn Taymiyya defines justice as "putting things in their places." It is apparent that he believes that human beings should intuitively recognize that God always puts things in their places, but he does not clearly define the rationality governing this justice. Although the shaykh speaks often of God's justice retributively, as in God's locating punishment in someone who disobeys, he rejects the strict retributivism of the Mu'tazilis. Instead, Ibn Taymiyya links God's justice to God's wise purpose, and, in ' $\bar{A} d i l$, he follows the rational and quranic imperatives to ascribe the highest perfection to God on to the conclusion that what God

${ }^{71}$ 'Ā dil, JR 142. 
creates is the best of all possible worlds, the inference likewise of Ibn Sinnā, al-Ghazāli and Ibn 'Arabī. In 'Ādil and in his other discussions of God's justice, the shaykh concerns himself very little with the origin and purpose of evil deeds, and the sphere of the human fades from view. In the final analysis, speaking of God's justice for Ibn Taymiyya is about exalting God's wise and good creation of all things. 


\section{CONCLUSION}

We are now in position to draw together the main results of this study and clarify how Ibn Taymiyya is similar to and different from others in the Islamic tradition. What emerges out of the shaykh's sundry theodicean writings is an optimism that is consistent but not always fully worked out. Over against Ash'arī voluntarism and the Mu'tazilī free-will theodicy, Ibn Taymiyya maintains that God in His perfection creates everything in existence, human acts included, according to His wise purpose and, ultimately, in the best possible way. This places Ibn Taymiyya in the company of Ibn Sinnā, al-Ghazālī in his I by $\vec{a}$, and Ibn 'Arabī on the central theological question of theodicy, even as he differs with these figures on other key matters.

Ibn Taymiyya's optimism is readily apparent in discussions linked to the first type of his three-fold evil attribution typology examined in Chapter Five. To review these three types briefly, the first attributes evil to the generality of God's creation. The second type ascribes evil to the creature or secondary cause. The third type is the rhetorical courtesy of eliding the agent of evil-presumably God-and putting the relevant verb in the passive voice; Ibn Taymiyyas discussion of this type is limited to citing examples from the Qur'an.

Attribution of evil to the generality, the first type, is understood in three ways in Ibn Taymiyya's discourse, each clearly echoing Ibn Sinnā. First, evil is harmful only to particular persons while being to the greater benefit of the whole. Everything that God creates, both good and evil, is good by virtue of His wise purpose. Ibn Taymiyya supports this with quranic verses such as, "Who made good everything He created" (Q. 32:7), and "We did not create the heavens and the earth and what is between them except with truth" (Q. 15:85), and the hadith, "Good is in Your hands, and evil is not [attributed] to You." In texts examined in Chapter Six, the shaykh also speaks of the goodness of all that God creates in terms of God's justice (' $\mathrm{adl}$ ) that puts everything in its place. Justice in this sense does not indicate pure retribution but God's wise purpose and beneficence in creation.

Second, evil is intrinsic to the perfection of some things. In Jabr Ibn Taymiyya explains that God is subject to logical constraints. God cannot create the impossible, and God in creating good must also create the evil that is necessarily concomitant to it. The shaykh then implies that God creates the best world that $\mathrm{He}$ can with an assertion of the necessary perfection 
of God's attributes of wisdom, power and mercy. He makes this optimism explicit in 'A $d i l$, a text dealing with God's justice, by rooting God's creation of the best possible world in the exigencies of God's perfection and generosity and endorsing al-Ghazālìss aphorism, "There is nothing in possibility more wonderful than what is." Lest this imply limitation to God's power and freedom, Ibn Taymiyya affirms that God can do other than what $\mathrm{He}$ in fact does.

Third, and finally, attributing evil to the generality means that evil is quantitatively insignificant. The shaykh notes in Hasana, for example, that the Messenger brought great profit even though some were killed in the course of his mission.

At times, Ibn Taymiyya states that God's wise purpose in the creation of evil cannot be known and that it is only important to believe that God has a wise purpose in all that $\mathrm{He}$ does. At other times, however, he does specify that evil has particular educational or religious benefits for human beings, which echo similar notions in $\mathrm{Mu}^{\prime}$ tazilism and Sufism. The unbelief and destruction of Pharaoh, for example, serve as a lesson and a deterrent against tempting the same fate. Illness and sin provide occasions for humble turning to God that would not be possible otherwise. Oppression under an unjust ruler expiates sins and motivates turning to God to ask forgiveness.

Even though Ibn Taymiyya supplies educational and religious reasons for evil, he does not exploit two other explanations for evil adopted by some Muslim optimists. First, unlike al-Ghazālī, Ibn Taymiyya does not explain that evil is necessary for knowledge in the sense that things are known only by their opposites. For al-Ghazālī, health is known through illness and the blessing of Paradise from the punishment of Hell. Second, unlike Ibn 'Arabī, Ibn Taymiyya does not readily invoke the principle of plenitude, which maintains that evil is necessary in order for God to display the full diversity of His names and attributes. The principle of plenitude would seem to be inherent in a fully worked out best-of-all-possible-worlds theodicy, and Ibn Taymiyya does suggest that creation reflects the diversity of God's names. As already noted, he even goes so far as to say that sin leads to good things not otherwise possible. However, the shaykh does not say explicitly, as does his disciple Ibn Qayyim al-Jawziyya, that God is dependent upon the existence of human sin and disobedience for the exercise of some of His attributes, and he does not explore and elaborate the paradoxical interplay of God's attributes in the fashion of Ibn 'Arabī. Rather, he is greatly concerned to avoid implicating God in evil and so affirms the complete goodness of all of God's names and attributes. 
With regard to the second type in Ibn Taymiyya's evil attribution typology - the attribution of evil to the creature-it seems probable that there was development in his thinking. In several texts, as in Minhäj for example, the shaykh establishes a basis for retribution with the principle that acts are attributed not to their Creator but to the human substrate in which they are created. With this, God is just to reward and punish the human deeds that $\mathrm{He}$ creates. This way of explaining the origin of sin and evil is more at home in the world of Kalām theology than in a full orbed best-of-allpossible-worlds theodicy. Also, it implies that God is ultimately responsible for bad acts insofar as He creates them.

In Hasana, which contains Ibn Taymiyya's fullest discussion of evil, he goes beyond the substrate principle to root evil in nonexistence ('adam) - a notion employed by Ibn Sīnā and Ibn 'Arabī for metaphysical and mystical ends, respectively - to strengthen the foundations of retributive punishment by clearing God of responsibility for creating human disobedience. Ibn Taymiyya claims in Hasana that two affirmations in Q. 4:78-9 are not contradictory: "Everything is from God," and, "Any evil thing that comes to you is from yourself." To make sense of this, he traces the origin of bad human acts back to the failure of humans to do that for which they were created. This failure is a lack which is by definition nonexistent, and so God is not responsible for it. The evil deeds that God creates are then retribution for this initial failure, while good deeds come strictly from God's unmerited grace and blessing, having no ground in human virtue and achievement. When faced with the question of why some people are created more prone to initial failure than others, the shaykh falls back on God's wise purpose in the creation of all things.

In Fätiha, which is likely a later treatise, Ibn Taymiyya similarly upholds retributive punishment for evil deeds but drops retributive reward for good deeds. He asserts that the blessings of good deeds, their rewards, and entry into Paradise have no basis in human merit but occur strictly by the grace of God. God is the only source of all good, and, in this case, piety calls for acknowledging God's grace for all good while maintaining full human responsibility for all evil, which arises ultimately from nonexistence.

Going beyond the interpretation of good and evil, Ibn Taymiyya uses ideas found also in Ibn Sinā to make sense of God's self-sufficiency. At the core of the shaykh's theodicy is a causal model of God's wisdom. God acts on account of causes, which are His wise purposes. To Ash' arī Kalām theologians, this implies that God is perfected by acting on account of a cause and was imperfect beforehand. This compromises God's sufficiency apart from the world. Both Ash'arī and Mu' tazilī Kalām theologians seek to avoid this 
problem with the doctrine of God's creation of the world in time ex nibilo. This assures that God is fully God apart from the world by positing a point at which the world did not in fact exist. The Mu'tazilis still try to affirm that God creates the world for purposes, purposes that benefit the world only and have no impact on God. But the Ash'aris-and Ibn Taymiyya-reject the Mu'tazilī solution as irrational. Ibn Taymiyya affirms fully that God acts in a rationally self-interested sense for the sake of His own wise purpose. This strongly suggests that God needs creation in order to work out His wise purposes and manifest His perfection. To meet this objection, Ibn Taymiyya employs the Avicennan notion that God's love for Himself is essential while the world is an accidental and secondary-even if necessary-product of God's self-love. Even though there has always been a world, this does not mean that God would be less fully God without it. Ibn Taymiyya argues as well that God is sufficient apart from the world inasmuch as He needs no help in creating all that exists. Creatures have no impact on God since it is God Himself who creates their acts.

While both Ibn Taymiyya and Ibn Sinā posit God's origination of the world as necessary, they differ on a key point. For Ibn Sinā, this world is a necessary emanation of the eternal and timeless essence of God. Ibn Taymiyya responds that positing the world as the effect of a timeless and motionless First Cause completely precludes movement in the world, which manifestly contradicts our experience of events originating in time. To overcome this problem, Ibn Taymiyya rejects the timeless ideal of God's perfection and introduces movement into both God and the world. He also discards Ibn Sinnās emanation cosmology and replaces it with God's voluntary, but perpetual, creativity. For Ibn Taymiyya, it is of the necessary concomitants of God's perfection and essence that $\mathrm{He}$ act and create by means of His will and power from eternity. Putting it more succinctly, God creates voluntarily by necessity. Ibn Taymiyya does not normally speak of time or originating events subsisting in God's essence. Rather he speaks of the perpetual dynamism of God in terms of God's voluntary attributes and acts, whose ongoing exercise according to God's wise purpose brings about their effects in the temporally created world, and, even though God could do other than what He does, what God does create at each point in time is the best possible for that time. With respect to creation itself, Ibn Taymiyya denies that anything in the world is eternal. Each individual created thing is preceded by nonexistence in time. Yet, there have always been created things, and the genus or species of created things is eternal.

Ibn Taymiyya's conciliation between the providentially necessitating God of Ibn Sīnā and the dynamic, personal and historically involved God found in 
his plain language reading of the Qur'an and Hadith is unusual and possibly unprecedented in the Islamic tradition. The shaykh achieves this conciliation by abandoning the ancient Greek philosophical ideal shared by medieval Kalām theologians, Muslim philosophers and philosophically-minded Sufis alike that the ultimate perfection of God consists in unchanging and motionless eternity. The perpetual and voluntary activity that is both necessary and essential to God's perfection is what most fundamentally distinguishes Ibn Taymiyya's optimism from the optimisms of Ibn Sīnā, Ibn 'Arabī, al-Ghazālī and their like.

When Ibn Taymiyya turns his attention to the relation of God's action to human action and accountability, he is most concerned to distinguish the two spheres clearly and give each its full due. That is, God is Creator of all existents including human acts, and human beings freely choose and are accountable for the deeds that they commit. The shaykh rejects any attempt to resolve the tension between these two spheres by limiting God's power on the one hand (Qadarīs and Mu'tazilīs) or limiting human responsibility on the other (Sufi antinomianism and theologies such as those of al-Juwayni and Ibn 'Arabī that allegedly undergird it). He also denies that the two spheres are contradictory, and he is unsympathetic to Ibn 'Arabî's understanding of reality as fundamentally paradoxical and ambiguous.

As shown in Chapter Three, the shaykh uses his divine action/human accountability or creation/command hermeneutic to bring order and sense to a wide array of quranic and theological terms. On the side of creation are also God's determination, decree and ontological words, while on the side of command are God's love, good pleasure, and legislative and religious words. Parallel to creation and command are also divinity and lordship, inspiration and piety/immorality (Q. 91:7-8). In this last set of terms, inspiration indicates creation, and the contrast between piety and immorality corresponds to legislation, that is, command and prohibition. Moreover, a number of quranic terms such as will, judgment, writing and authorization carry an ontological, determinative sense in some instances and a legislative or religious sense in others. At times, Ibn Taymiyya finds it necessary to clarify that terms often associated with one sphere may carry senses appropriate to the other, as when he specifies-against Ibn 'Arabī-that 'decree' carries a legislative sense in the verse, "Your Lord has decreed that you serve none but Him" (Q. 17:23). The shaykh's concern throughout is to undermine interpretations that he believes lead to antinomianism, especially al-Juwaynī's equation of God's love with God's ontological will.

It is particularly in Minhajj, writing against the Mu'tazili polemic of the Shîī Ibn al-Muțahhar al-Hillīi, that Ibn Taymiyya seeks to defend the 
plausibility of adhering fully to both creation and command by offering illustrations from human affairs. In one type of illustration, Ibn Taymiyya observes that God may will to create what opposes His command for the sake of something else-some wise purpose-that He loves, as when a sick person takes medicine to attain health. In another kind of illustration, the shaykh distinguishes the will of an agent to perform an act himself (creation) and his will that someone else perform an act (command). He observes, moreover, that an agent may have a wise purpose in commanding someone to do something without helping him to do it, as for example in the quranic story of the one who advised Moses to flee but did not help Moses in order to avoid detriment to himself (Q. 28:20). While Ibn Taymiyya recognizes that such examples do not apply perfectly to God, he argues that, if it is possible that commanding but not helping is at times wise for creatures, such wise intentions are a fortiori possible for God.

Ibn Taymiyya's creation/command hermeneutic extends as well into his treatment of the human act. On the creation side, God creates a power, capability, decisive will or some combination thereof in the human being to necessitate or preponderate the existence of the human act. This view of God's creation of the human act by means of power or will is essentially that of Fakhr al-Dīn al-Rāzī. Its roots lie in the preponderance (tarjīh) terminology of the Mu'tazilīs and in Ibn Sīnās language of causality, but neither al-Rāzī nor Ibn Taymiyya subscribe to a causal chain theory into which God cannot intervene. Both al-Rāzī and Ibn Taymiyya dismiss the early Ash'arī doctrine of acquisition (kasb) as meaningless. Yet, while al-Rāzì openly identifies his view as compulsion ( $j a b r)$, the shaykh wishes not to speak of compulsion lest it be confused with coercion (ikräh), which nullifies human will and choice entirely. For Ibn Taymiyya, God cannot be said to coerce because He creates the will and free choice by which human beings act voluntarily.

Corresponding to the realm of command is the human power or capability that is anterior to God's creation of the act and constitutes the bodily soundness rendering a human being accountable to God's legislation. Similarly, on the side of command and human action are the secondary causes, which include, among other things, God's guidance and the human will. From this perspective, humans live in a predictable world of apparently natural causes and conditions, and involuntary human acts are distinguished from voluntary acts inasmuch as the latter come into existence by means of the human will. However, God can break the natural order of the causes whenever He wills, and, from the side of God's creation, it is God who employs the secondary 
causes as instruments and raw materials according to His wise purposes to originate all that occurs.

Al-Rāzī sometimes maintains the compatibility of God's preponderance or creation of the human act with human accountability, but at least once-in his Tafsir - he rigorously spells out how they contradict one another. By way of contrast, Ibn Taymiyya consistently denies contradiction between God's determination of the human act and human free choice, and on occasion he presents their compatibility as the golden mean between the extremes of compulsion ( $j a b r$ ) and denying God's all-comprehensive power. Nevertheless, he does encounter rational difficulties. In response, he simply affirms that God has a wise purpose in all that He creates, or he diverts his reader's attention from the divine perspective to the human. A clear example of the latter is his response to al-Rāzîs claim that God obligates humans to do the impossible. Al-Rāzī argues that God obligated Abū Lahab to do the impossible when God commanded him to believe because God's foreknowledge necessitated that he not believe. Although Ibn Taymiyya cannot deny that this is so metaphysically, he sidesteps al-Rāzîs's conclusion by switching to the human ethical perspective in which belief was indeed obligatory for Abū Lahab. Moreover, the shaykh argues, God did not inform Abū Lahab that He already knew that he would not believe.

From the above, it is apparent that Ibn Taymiyya's theodicean writings constitute a concerted attempt to exegete and rationalize the relevant texts in the Qur'an and the Hadith into a consistent perpetual optimism in theodicy and compatibilism in the human act. In order better to understand the underpinnings of this, Chapter One sought out texts beyond the theodicean writings that provided clues to Ibn Taymiyya's theological methodology. This showed that Ibn Taymiyya's theological work may be characterized as a juristic exercise dedicated to finding the most praiseworthy way to speak about God and that this is part of the shaykh's wider practical and juristic effort to ascertain how correctly to worship God in all aspects of life. Basic to Ibn Taymiyya's theological jurisprudence is the principle-grounded both in rational considerations of causality and in the quranic verse, "To God is the highest similitude" (Q. 16:60) — that God has an a fortiori right to ascription with the highest human perfections and to exoneration from all imperfections. With this principle in place, Ibn Taymiyya affirms the full reality of all attributes ascribed to God in the Qur'an and the Hadith, while also affirming that both God's perfection and the verse, "There is nothing like Him" (Q. 42:11), dictate that the modalities of these attributes be wholly 
unlike those of creatures. Within this framework, the shaykh explicates the significance, coherence and faithfulness to tradition of his plain language reading of the theological data in the revealed texts, and he makes and seeks to demonstrate the apologetic claim that independent reason rightly exercised leads to speaking about God in the same way.

Ibn Taymiyya's approach to God's attributes and theological language differs from a number of others in the Islamic tradition. Unlike the Kalām theologians, the shaykh sees no need to reinterpret corporeal attributes such as God's hand and God's sitting to give them meanings allegedly more fitting to God. He typically tries to interpret God's attributes according to their linguistic and contextual senses and to show how these meanings fit together. He avoids anthropomorphism by maintaining that it is of the perfection of God's perfection that all of God's attributes be wholly unlike their counterparts in creatures, except in name. In contrast to the Muslim philosophers and Ibn 'Arabī, Ibn Taymiyya's approach is also distinctively egalitarian. Unlike the philosophers, he does not draw a distinction between a superior intellectual apprehension of the truth by the elite on the one hand and the imaginal reports of God's messengers adapted for easy apprehension by the inferior masses on the other. And while Ibn Taymiyya and Ibn 'Arabī share in rejecting Kalām reinterpretation $\left(t a^{a} w \bar{\imath} l\right)$ of God's corporeal attributes, the Hanbali jurist distinguishes himself from the Sufi theorist by drawing a sharp line between the Creator and the creature. He affirms the ontological reality of God's names and attributes, leaves no room for the illumined gnostic to see created things as God's very acts, and refrains from esoteric interpretation. Additionally, Ibn Taymiyya breaks with the unreflective traditionalism of Hanbalī forbears such as Ibn Qudāma. Instead, he engages in interpretation of the meanings of God's attributes and makes the apologetic claim that his views accord with reason. For Ibn Taymiyya, reason and revelation lead to the same truth, and this truth about God is equally available to all ordinary people of right mind.

With the basic elements of Ibn Taymiyya's apologetic theological jurisprudence in view, his theodicy provides an important case study in its implementation. Here, several features of his methodology become apparent. The quranic and rational imperative to ascribe to God the highest perfection or similitude means avoiding terms that may carry negative connotations in ordinary speech and/or whose usage is not required by revelation. Thus, Ibn Taymiyya speaks not of purpose (gharad) but of wise purpose ( $h i k m a)$, not of compulsion ( $j a b r)$ but of creating and making ( $\left.j a^{\prime} l\right)$, and not of originating events in God's essence but of God's voluntary attributes and acts, this even though the respective terms mean the same thing metaphysically. More 
substantively, giving God the highest similitude involves Ibn Taymiyya in clarifying the characteristics of God's perfection and identifying why competing theodicies are wrong. With reason and the revealed tradition interpreted by the Salaf as his stated authorities, the shaykh takes God's perfection to consist in willing and creating things in the world for wise purposes from eternity in the best possible way. He criticizes the Mu'tazilis and the Ash'arīs for failing, each in their own way, to ascribe to God the highest similitude or perfection. The imperative to ascribe perfection to God also entails a rationalism for Ibn Taymiyya that seeks to resolve or at least find plausible ways to understand rational difficulties such as the origin of evil and the conundrum of creation and command.

In the end, Ibn Taymiyya's best-of-all-possible-worlds theodicy is testimony to a deep conviction that proper worship of God requires making laudable sense out of the revealed tradition and showing that this accords with reason. His perpetual optimism constitutes an apologetic rationalization of a close ordinary language reading of what Islam's foundational texts say about God's moral relationship to the world. The present study has been devoted primarily to elucidating the contours of this apologetic rationalization and showing how it works. This hopefully sets the stage for further exploration in three directions. First, other aspects of Ibn Taymiyya's theology await more detailed exposition and analysis, especially his doctrine of God's attributes surveyed in Chapter One. Second, much work remains to clarify how Ibn Taymiyya appropriated the thought of those he read, especially Ibn Sinnā, Ibn 'Arabī and Fakhr al-Dīn al-Rāzī, as well as Ibn Rushd and Abū al-Barakāt al-Baghdādī. The latter two figures have received comparatively little attention in this study, but they may well be no less important to Ibn Taymiyya's intellectual formation. Third, the strong modern interest in Ibn Taymiyya warrants extensive research into how and why his theodicy, and his theology more generally, have been appropriated by successors, both late-medieval and modern. It seems likely that Ibn Taymiyya's egalitarian and non-esoteric approach to interpretation combined with his rationalization of the theological evidence in Islam's source texts is one reason many Muslims have been drawn to him in the rationalistic and egalitarian age of modernity. 



\title{
BIBLIOGRAPHY
}

\author{
Ibn Taymiyya's Writings
}

\section{Collected Works with Abbreviations}

JR

$\mathrm{MCD}$

MF

MFCD

MRK 1

MRK 2

MRM

Jāmi al-rasāill li-Ibn Taymiyya. Ed. Muhammad Rashād Sālim. Vol. 1. Cairo: Mațba'at al-madanī, 1389/1969.

Mu' allafät al-shaykh wa tilmìdhihi Ibn al-Qayyim. CD ROM. Version 1.0. Amman: Markaz al-turāth li-abhāath al-ḥāsib al-ālī, 1420/1999. This CD contains most of Ibn Taymiyya's published works.

Majmū fatāwā shaykh al-Islām A Ạmad b. Taymiyya. Ed. 'Abd al-Rahmān b. Muhammad b. Qāsim and Muhammad b. 'Abd al-Raḥmān b. Muhammad. 37 vols. Cairo: Dār al-Raḥma, n.d. Henri Laoust, La profession de foi d'Ibn Taymiyya: Texte, traduction et commentaire de la Wäsitiyya (Paris: Librairie Orientaliste Paul Geuthner, 1986), 91, gives the publication dates of the original Riyadh edition of MF as 1381-6/1961-7. MF includes all items found in MRM below.

Majmü fatāwà Ibn Taymiyya. CD ROM. Version 1.0. Cairo: Sharikat Harf li-taqniyyat al-ma'lumāt, 1999. This is MF on CD ROM. Citations are made strictly from the print version. As of December 2006, MF was also available at http://ibntaimiah.al-islam.com/, but unfortunately volume and page numbers from the printed text were not provided.

Majmū at al-rasä il al-kubrā. Vol. 1. Cairo: Al-Mațba'a al-āmira al-sharafiyya, 1323/1905.

Majmü' at al-rasā̄il al-kubrā. Vol. 2. Beirut: Dār ihyā') al-turāth al-'arabī, 1392/1972.

Majmū à al-rasǟil wa al-masä̀il. Ed. Muhammad Rashīd Riḍā. 5 parts. Cairo: Maṭba'at al-manār, 1341-9/1922-1930. All items in MRM have been integrated into MF.

\section{Ibn Taymiyya's Treatises with Short Titles}

Ibn Taymiyya's writings used in this study are alphabetized here by their respective short titles, which in many cases are those used by Laoust in La profession, 89-93. For treatises appearing in more than one published work, citation is made to the first mentioned work only, except for Minhaj $\bar{j}$, in which case the reference is also followed by a slash and the equivalent location in MinhäjB. Some shorter writings have not been given short titles and are cited in the text only by their locations in the respective collections.

'Abd al-Qādir "Fī sharḥ kalimāt li-'Abd al-Qādir fi kitāb Futūḥ al-ghayb." MF 10:455548.

Abū al-Fid $\vec{a} \quad$ "A Letter of Ibn Taymiyya to Abū l-Fidāe." Ed. Serajul Haque. In Documenta Islamica Inedita, ed. Johann W. Fück, 155-161. Berlin: Akademie-Verlag, 1952. Reprinted with translation in Jean R. Michot, Ibn Taymiyya: Lettre

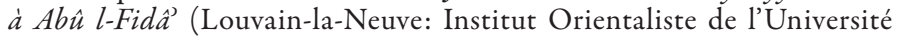
Catholique de Louvain, 1994), 43-67 (French), 83-7 (Arabic). References are to the Arabic of Michot following Haque's pagination, which Michot includes as well. 
Abū Dharr "Sharḥ hạaīth annī ḥarramtu al-ẓulm 'alā nafsīi," or "An ma'nā ḥadīith Abī Dharr... yā 'ibādī annī harramtu al-zulm 'alā nafsī.” MF 18:136-209.

'Ádil "Qāida fì ma' nā kawn al-Rabb 'ādilan wa fì tanazzuhihi 'an al-zulm wa fí ithbāt 'adlihi wa ihsānihi.” JR 121-142.

Akmaliyya "Al-risāla al-akmaliyya." MF 6:68-140.

A'lā "Tafsìr sūrat al-A'lā." MF 16:82-216.

'Alaq "Tafsīir sūrat al-'Alaq." MF 16:251-476.

Amr "Al-Amr bi-l-ma'rūf wa al-nahy 'an al-munkar." MF 28:121-178. Also in Istiqāma, 2:198-311.

Amrāe Amrāẹ al-qulūb wa shifā̄uhā." MF 10:91-137.

Awliy $\vec{a} \quad$ "Al-Furqān bayn awliyāà al-Rahmān wa awliyāà al-Shayț̄n." MF 11:156-310.

Bațāihiyya "Munāẓarat Ibn Taymiyya li-dajajilat al-bațāihịiyya." MF 11:445-475, and MRM 1:121-146.

Bughya Kitäb bughyat al-murtād fì al-radd 'alā al-mutafalsifa wa al-qarämita wa albätininiyya (also called Al-Saba'inizya). Ed. Faraj Allāh Zakī al-Kurdī al-Azharī. Cairo: Maṭba'at al-kurdistān al-'ilmiyya, 1329/1911.

Dar' Dar' ta'ärud al-'aql wa al-naql. Ed. Muhammad Rashād Sālim. 11 vols. n.pl.: n.p., n.d. Dar', 1:3-4:295 corresponds to Bayān muwäfaqat șarīh al-máqül li-sabìh al-manqūl previously published on the margin of MinhäjB. Dar', 1:2-3:87 corresponds to Muwäfaqat șahīh al-manqül li-șarìh al-ma'qül, ed. Muhammad Muhyī al-Dīn 'Abd al-Hamìd and Muhammad Hāmid al-Fiqī (Cairo: Matba'at al-sunna al-muhammadiyya, 1370/1951). Information concerning this latter edition is based on Sălim's notes in the introduction to Dar', 1:66-70, since it was not available to me directly.

Darajāt "Fì darajāt al-yaqīn." MF 10:645-652, and MRK 2:157-164.

Fätiḩa "Ammā hadīth fātihat al-kitāb..." MF 14:4-36. MF 14:5-36 is also in Kitāb al-Tawhìd. Ed. Muhammad al-Sayyid al-Julaynad, 37-68. Cairo: Dār al-fikr al-hadīth li-l-tibā'a wa al-nashr, 1973.

Fī Fușūs "Al-Radd al-aqwam 'alā mā fì Fușūs al-ḅikam." MF 2:362-451.

Fì wujūb "Fì wujūb ikhtișās al-khāliq bi-l-ibāda wa al-tawakkul." MF 1:37-63.

Fițra "Risāla fì kalām 'alā al-fițra." MRK 2:333-349. Trans. Geneviève Gobillot, "L'Épître du discours sur la fitra (Risäla fî-l-kaläm 'alä-l-fitra) de Taqi-l-Dīn Ahmad Ibn Taymīya (661/1262-728/1328)," Annales Islamologiques 20 (1984): 29-53.

Furqān "Risālat al-furqān bayn al-ḥaqq wa al-bāṭil." MF 13:6-229, and MRK 1:1179 .

Hamawiyya "Al-'Aqīda al-hamawiyya al-kubrā." MF 5:5-120, and MRK 1:414-469.

Hasana "Al-Hasana wa al-sayyia." MF 14:229-425. Also, Al-Hasana wa al-sayyia. Beirut: Dar al-kutub al-ilmiyya, n.d. Also, Al-Hasana wa al-sayyi a. Ed. Muhammad Jamīl Ghāzī. Cairo: Maṭba'at al-madanī, n.d. on MCD. Also, $\mathrm{Al}$ Hasana wa al-sayyi a. Ed. and Introduction Muhammad Jamīl Ahmad Ghāzī. Beirut: Dār al-jīl, 1410/1990. Also in Al-Tafsìr al-Kabìr, ed. 'Abd al-Raḥmān 'Amīra, 3:257-456. Beirut: Dār al-kutub al-'ilmiyya, 1408/1988. An unnamed fatwa in MF 8:204-234 abridges Hasana MF 14:294-361.

Ibtạl "Ibtạāl waḥdat al-wujūd." MF 2:286-361, and MRM 1.61-120.

I ḩ̣tijāj "Risāla fì al-ihtijāj bi-l-qadar." MF 8:303-370, and MRK 2:97-155.

Ikhlās $\quad$ Tafsìr surat al-Ikhläs. MF 17:214-503. Also, Tafsìr surat al-Ikhläṣ. Bombay: Dār al-salafiyya, 1408/1987.

Ikhtiyāriyya "Faṣl fī al-ṣifāt al-ikhtiyāriyya." MF 6:217-267.

Iklīl "Risālat al-iklīl fì al-mutashābih wa al-tàwīl." MF 13:270-313, and MRK 2:3-36.

İmān I Al-İmān. MF 7:4-460. Also, Al-İmān. Cairo: Dār 'ālim al-márifa, 1413/1993. Trans. Salman Hassan Al-Ani and Shadia Ahmad Tel, Kitab Al-Iman: Book of Faith (Bloomington, IN: Iman Publishing House, 1999). 
İmān II "Kitāb al-īmān al-awsaț." MF 7:461-640.

'Imrān "Sharḥ ḥadīth 'Imrān b. Huṣayn." MF 18:210-243, and MRM 5:172-195. Trans. Jon Hoover, "Perpetual Creativity in the Perfection of God: Ibn Taymiyyas's Hadith Commentary on God's Creation of this World," Journal of Islamic Studies 15:3 (Sept. 2004): 287-329.

Iqtid̄a $\quad$ Iqtid̄a al-șirăt al-mustaqim mukhälafat aṣhāb al-jahim. Ed. Ahmad Hamdī Imām. Jedda: Dār al-Madanī, 1406/1986. Trans. Muhammad Umar Memon, Ibn Taimiya's Struggle against Popular Religion (The Hague: Mouton, 1976).

Iräda "Aqwam mā qïla fì al-qadā' wa al-qadar wa al-hikma wa al-tálili." MF 8:81-158 and MRM 5:113-170. Same as "Al-Irāda wa al-amr" in MRK 1:318-386.

Isfahāniyya Sharh al-'aqìda al-Ișfahāniyya. Ed. Hasanayn Muḥammad Makhlūf. Cairo: Dār al-kutub al-islāmiyya, n.d.

Istiqāma Al-Istiqāma. Ed. Muḥammad Rashād Sālim. 2 parts. Beirut: Dār Ibn Hazm, $1420 / 2000$.

Istițāa "Qad takallama al-nās min aṣhābina wa ghayrihim fì istițấat al-'abd..." MF 8:371-6.

Ittihādiyyin "Haqīqat madhhab al-ittihādiyyīn wa wah̆dat al-wujūd." MF 2:134-285 and MRM 4:1-101.

Jabr "Su'ila Shaykh al-Islam...fa-qīla: yā ayyuhā al-habr alladhī..." or "Su'ila 'an abyāt fì al-jabr." MF 8:448-515.

Jahd "Jahd al-qarīha fị tajrīd al-naṣịha." MF 9:82-254. Jalāl al-Dīn al-Suyūṭīs abridgement of Ibn Taymiyya's Mantiqiyyin. Trans. Wael B. Hallaq, Ibn Taymiyya against the Greek Logicians (Oxford: Clarendon Press, 1993).

Jawāb Al-Jawāb al-șahīh li-man baddala din al-Masīh. Ed. 'Alī b. Hasan b. Nāṣir, 'Abd al-'Azīz b. Ibrāhīm al-'Askar, and Hamdān b. Muhammad al-Hamdān. 7 vols. Second printing. Riyāḍ: Dār al-'̄assima li-l-nashr wa al-tawzīé , 1419/1999. Partial trans. Thomas F. Michel, A Muslim Theologian's Response to Christianity (Delmar, NY: Caravan Books, 1984).

Kasb "Mā qawl ahl al-kalām ...fa-haqīiqat kasb al-'abd, mā hiya?” MF 8:386-405.

Kaylāniyya "Al-Kaylāniyya." MF 12:323-501.

Khawd "Su'ila hal yajūz al-khawḍ fìmā takallama al-nās fihi min masāìl ușūl al-dīn..." MF 3:293-326 (missing response to last question in opening inquiry). Ibn Taymiyya copied the full original text into Dar', 1:25-78.

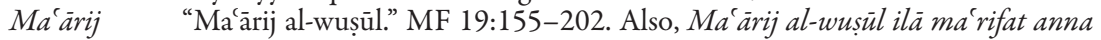
usūul al-dìn wa-furū ahu qad bayyanahā al-Rasūl. Ed. Muhammad Badr al-Dīn Abū Farrās al-Na'sānī al-Halabī. Cairo: Al-Maṭa'a al-āmira al-sharafiyya, 1323/1905-6. Trans. Abou Ilyâs Mouhammed Diakho, Exposé de scolastique islamique (Ma'ârej al-wuçûl ila 'ilm al-uçül) (Beirut: Dar Al-Bouraq, 1417/1996).

Mahabba Qäidafíal-mahabba. Ed. Muhammad Rashād Sālim. Cairo: Maktabat al-turāth

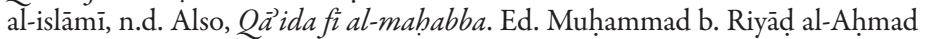
al-Atharī. Beirut: 'Ālam al-kutub, 2005.

Manbijī "Fī risālatihi ilā Nașr al-Manbijī." MF 2:452-479, and MRM 1.161-182.

Manțiq Naqdal-Mantiq. MF 4:1-190 and continued in MF 9:5-81. This is equivalent to 1-155 and 155-210, respectively, in Naqd al-manțiq. Ed. Muhammad b. 'Abd al-Razzāq Hamza, et al. Cairo: Maktabat al-sunna al-muhammadiyya, n.d.

Manțiqiyyīn Kitäb al-radd 'alā al-manțiqiyyìn. Ed. 'Abd al-Ṣamad Sharaf al-Dīn al-Kutubī. Bombay: Al-Mațba'a al-qayyima, 1368/1949.

Marātib "Marātib al-irāda." MF 8:181-196. A longer version exists in MRK 2:69-85.

Minhāj Minhāj al-sunna al-nabawiyya fì naqud kaläm al-Shī'a al-Qadariyya. Ed. Muhammad Rashād Sālim. 9 vols. Riyadh: Jāmi'at al-Imām Muhammad b. Su'ùd al-Islāmiyya, 1406/1986. Citations in this study are given first to this edition and secondly to the equivalent pages in MinhäjB. 
MinhäjA Minhäj al-sunna al-nabawiyya fì naqd kaläm al-Shì' a al-Qadariyya. Ed. Muhammad Rashād Sālim. 2 vols. Cairo: Matba' at al-madanī, 1962. This two volume critical edition of Sālim only reaches MinhäjB 1:264 and was never completed. These two volumes were revised when published later in Minhäj.

MinhäjB Minhäj al-sunna al-nabawiyya fì naqd kaläm al-Shì a wa al-Qadariyya. Beirut: Dār al-kutub al-'ilmiyya, n.d. 4 vols. Reprint of 1321/1903-4 Cairo (Būlāq) edition. See Minhäj and MinhäjA for critical editions of this work. See Minhäj for note on citation.

Munāzara "Munāẓara fì al-'aqīida al-Wāsițiyya." MF 3:160-193. Trans. Sherman Jackson, "Ibn Taymiyyah on Trial in Damascus," Journal of Semitic Studies 39 (Spring 1994): 41-85.

Nubuwwāt Kitāb al-nubuwwāt. Beirut: Dār al-qalam, n.d.

Nür

Nuzūl

Qad $\vec{a}$

Qadariyya

"Tafsīr sūrat al-Nūr." MF 15:280-359.

"Sharh hadīth al-nuzūl." MF 5:321-582.

"Fī al-qadä' wa al-qadar." MF 8:262-271. Also in MRK 2:87-95 with slight differences.

Qawl'Alī

"Qad dhakartu fī ghayr mawdi' anna al-qadariyya thalāthat aṣnāf." MF 8:256-261.

Qiyās

"An qawl 'Alī raḍiya Allāh 'anhu: Lā yarjūna 'abd illā rabbahu..." MF 8:161-180.

"Risāla fì ma nā al-qiyās." MF 20:504-583, and MRK 2:235-291. Trans. Henri Laoust, Contribution à une étude de la méthodologie canonique d'Ibn Taymiyya (Cairo: Institut français d'archéologie orientale, 1939), 113216.

Qubrusiyya Al-Risāla al-qubruṣiyya: Ilā malik Qubruṣ al-Naṣrānī" In MF 28:601-630. Trans. Jean R. Michot, Ibn Taymiyya: Lettre à un roi croisé (Al-Risâlat alQubrusiyya) (Louvain-la-Neuve, Bruylant-Academia, 1995).

Qudra "Fì qudrat al-Rabb 'azza wa jalla." MF 8:7-57.

Ridāa

"'Amma dhakara al-ustādh al-Qushayrī fì 'Bāb al-riḍā' 'an al-Shaykh Abū Sulaymān..." MF 10:678-720.

Sa'āda “An qawm qad khuș̣ū bi-l-sa'āda...” MF 8:272-302.

Safadiyya Kitāb al-șafadiyya. 2 parts in 1 vol. Ed. Muhammad Rashād Sālim. Manșūra, Egypt: Dār al-hudā al-nabawiyya, 1421/2000.

Sārim Al-Sārim al-maslūl 'alā shātim al-rasūl. Ed. Khālid 'Abd al-Lațîf al-Sab' al'Alamī. Beirut: Dār al-kitāb al-'arabī, 1416/1996.

Shams "Tafsīir sūrat al-Shams." MF 16:226-250.

Shirk "I'lam, rahimaka Allāh, anna shirk bi-Allāh a'ẓam dhanb..." MF 1:88-96.

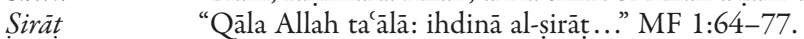

Siyàsa "Al-Siyāsa al-shar iyya fì iṣlāḥ al-rā̄ì wa al-ra iyya." MF 28:244-397. Trans. Omar A. Farrukh, Ibn Taimiyya on Public and Private Law in Islam (Beirut: Khayat, 1966). Trans. Henri Laoust, Le traité de droit public d'Ibn Taymiyya (Damascus: Institut français de Damas, 1948).

Süfryya "Risāla fì al-șüfiyya wa al-fuqaāà." MF 11:5-24. Trans. Th. E. Homerin, "Ibn Taimiya's Al-Sufiyya wa-al-fuqarä,’, Arabica 32 (1985): 219-244.

$T_{a \bar{a}} \mathrm{a} a$ “An al-'abd: hal yaqdir an yaf'al al-țā'a...” MF 8:437-447.

Tadmuriyya "Al-'Aqìda al-Tadmuriyya." MF 3:1-128.

Tabsin al-'aql "Ammā mas’alat tahsinn al-'aql wa taqbīhihi...” MF 8:428-436.

Tä̀iyya

"Al-Tāiliyya." MF 8:245-255. Ed. and English summary Serajul Haque, "A Poem of Imām Ibn Taymiyya on Predestination," Journal of the Asiatic Society (Pakistan) 1 (1956): 1-17.

Talbiss Bayān talbìs al-jahmiyya fî̀ ta'sis bida' ibim al-kalämiyya, or Naqd ta'sīs al-jahmiyya. 2 vols. Ed. Muḥammad b. 'Abd al-Raḥmān b. Qāsim. n.pl.: Mu'assasat qurțuba, n.d. 
Taraddud “Su'ila 'an qawlihi mā taraddadtu 'an shay'...” MF 18:129-135. Trans. Yahya Michot, Un Dieu hésitant? (Beirut: Dar Al-Bouraq, 1425/2005).

Tawakkul "An mā qālahu Abū Hāmid al-Ghazālī fì kitābihi...fī al-tawakkul..." MF $8: 524-539$.

Tawassul "Al-Qāiida fī al-tawassul wa al-wasīla." MF 1:142-368.

Tawba "Fì anna al-tawba wa al-istighfār yakūn min tark al-wājibāt wa fíl almuharramāt." MF 11:670-695.

Tawhīd "Qāiida fī tawhīd al-ilāhiyya." MF 1:20-36. Also in Kitāb al-Tawhìd. Ed. Muhammad al-Sayyid al-Julaynad, 19-36. Cairo: Dār al-fikr al-ḥadīth li-ltibāía wa al-nashr, 1973.

Thulth "Jawāb ahl al-'ilm wa al-īmān anna 'qul huwa Allāh ahad' ta'dilu thulth al-Qửān.” MF 17:5-205.

Tuhfa "Al-tuḥfa al-irāqiyya fī al-a'māl al-qalbiyya." MF 10:5-90.

'Ubüdiyya "Risālat al-'ubūdiyya." MF 10:149-236. Trans. in James Pavlin, "The Concept of 'Ubüdiyyah in the Theology of Ibn Taymiyyah: the Relationship between Faith, Love and Actions in the Perfection of Worship," (Ph.D. diss., New York University, 1998), 185-365.

Wāsita "Al-Wāsiṭa bayn al-khalq wa al-haqq." MF 1:121-138. Also, Al-Wāsita bayn al-khalq wa al-haqq. Ed. Muhammad Darwīsh Muṣtafa al-Minyāwī. Cairo: Maktabat wa mațba'at al-ittihād al-akhawī, n.d. Trans. Yahya J. Michot, "Ibn Taymiyya: Les intermédiaires entre Dieu et l'homme (Risâlat al-wâsiṭa bayna l-khalq wa l-haqq)," Le Musulman (Paris) Special Issue (1996).

Wäsitiyya "Al-'Aqīda al-wāsițiyya." MF 3:129-159, and MRK 1:387-406. Also, ed. and trans. Henri Laoust, La profession de foi d'Ibn Taymiyya: La Wāsițiyya (Paris: Librairie orientaliste Paul Geuthner, 1986). Trans. Merlin Swartz, "A seventh-century (A.H.) Sunnī creed: The 'Aqīda Wāsitīya of Ibn Taymīya," Humaniora Islamica, 1 (1973): 91-131. Trans. Clemens Wein, Die Islamische Glaubenslehre ('Aqida) des Ibn Taimiya (Bonn: n.p., 1973).

Wasiyya kubrā "Al-Wașiyya al-kubrā." MF 3:363-430, and MRK 1:262-317.

Wașiyya sughrā “Al-Wașiyya al-sughrā” MF 10:653-665.

\section{Works of Others Found in the Collected Works of Ibn Taymiyya}

"Hikāyat al-Shaykh 'Alam al-Dīn li-l-munāẓara fī al-Wāsițiyya." Account by Syrian historian 'Alam al-Din al-Birzālī. MF 3:194-201, and MRK 1:407-413.

"Kataba 'Abd Allāh b. Taymiyya li-akhīhi Zayn al-Dīn 'an hāṣil al-munāẓara fī al-majlis althānī.” Letter of Ibn Taymiyya's brother, Sharaf al-Dīn 'Abd Allāh. MF 3:202-210.

\section{Other Arabic and Western Language Sources}

Abrahamov, Binyamin. "Al-Ghazālī’s Theory of Causality." Studia Islamica 67 (1988): 75-98.

——. "Ibn Taymiyya on the Agreement of Reason with Tradition." The Muslim World 82:3-4 (July-Oct. 1992): 256-273.

- - Islamic Theology: Traditionalism and Rationalism. Edinburgh: Edinburgh University Press, 1998.

- - "A re-examination of al-Ash'arī's theory of kasb according to Kitāb al-luma ." Journal of the Royal Asiatic Society. 1989 ii: 210-221.

Abū al-Barakāt, Hibat Allāh b. 'Alī b. Malkā al-Baghdādī. Kitāb al-mu'tabar fì al-hikma. 3 vols. Hyderabad: Jam'iyyat dā'irat al-ma'ārif al-'uthmāniyya, 1357-8/1938-9.

Abū Ya' lā Ibn al-Farrā'. Kitāb al-mu'tamad fì uṣūl al-dìn. Ed. Wadi Z. Haddad. Beirut: Dar el-machreq, 1974. 
Abū Zayd, Mūnā Ahmad Muhammad. Mafhūm al-khayr wa al-sharr fì al-falsafa al-Islāmiyya: Dirāsa muqūrana fì fikr Ibn Siñā. Beirut: Al-mu'assasa al-jāmi' iyya li-I-dirāsāt wa al-nashr wa al-tawzíc, 1411/1991.

Acar, Rahim. "Avicenna's Position Concerning the Basis of the Divine Creative Action." The Muslim World 94 (2004): 65-79.

- - Talking about God and Talking about Creation: Avicenna's and Thomas Aquinas' Positions. Leiden: Brill, 2005.

Adams, Marilyn McCord. Horrendous Evils and the Goodness of God. Ithaca, NY: Cornell University Press, 1999.

Adamson, Peter, and Richard C. Taylor, eds. The Cambridge Companion to Arabic Philosophy. Cambridge, UK: Cambridge University Press, 2005.

Adang, Camilla. "Islam as the Inborn Religion of Mankind: The Concept of Fitra in the Works of Ibn Hazm." Al-Qantara 21 (2000): 391-410.

Ahmed, Shahab. "Ibn Taymiyyah and the Satanic verses." Studia Islamica 87 (1998): 67-124.

Ali, Mohamed M. Yunis. Medieval Islamic Pragmatics: Sunni Theorists' Models of Textual Communication. Richmond, Surrey, UK: Curzon Press, 2000.

Alousï (al-), Husâm Muhî Eldîn. The Problem of Creation in Islamic Thought: Qur'an, Hadith, Commentaries, and Kalam. Baghdad: The National Printing and Publishing Co., 1965.

Ani (al-), Salman Hassan, and Shadia Ahmad Tel, trans. Ibn Taymiyyah: Kitab Al-Iman: Book of Faith. Bloomington, IN: Iman Publishing House, 1999.

Arnaldez, Roger. "Apories sur la prédestination et le libre arbitre dans le commentaire de Razi." Mélanges de linstitut dominicain d'études orientales 6 (1959-1961): 123-136.

Ash'arī (al-), Abū al-Hasan 'Alī b. Ismā'ìl. Kitāb al-luma'. In Richard J. McCarthy, The Theology of al-Ash' arī, 5-83 (Ar.) and 5-116 (trans.). Beirut: Imprimerie Catholique, 1953.

- - Risäla fì istihsān al-khawd fì 'ilm al-kaläm. In Richard J. McCarthy, The Theology of al-Ash' ari, 85-97 (Ar.) and 117-134 (trans.). Beirut: Imprimerie Catholique, 1953.

Ashqar (al-), Umar Sulaymān. 'Ālam al-jinn wa al-shayyāținn. Cairo: Bayt al-Hikma, $1413 / 1992$.

- - . The World of the Jinn and Devils. Trans. Jamaal al-Din M. Zarabozo. Boulder, CO: Al-Basheer, 1998. Trans. of 'Älam al-jinn wa al-shayyātīn.

Austin, 'Umar. "Suffering in Muslim Religious Thought." The Islamic 2uarterly 26.1 (1982): 27-39.

Awn, Peter J. Satan's Tragedy and Redemption: Iblìs in Sufi Psychology. Leiden: E.J. Brill, 1983.

Azmeh (al-), Aziz. "Orthodoxy and Hanbalite Fideism." Arabica 35 (1988): 253-266.

Bell, Joseph Normant. Love Theory in Later Hanbalite Islam. Albany, NY: State University of New York Press, 1979.

Belo, Catarina. Chance and Determinism in Avicenna and Averroes. Leiden: Brill, 2007.

Bori, Caterina. Ibn Taymiyya: una vita esemplare Analisi delle fonti classiche della sua biografia. Supplemento N. 1. Rivista Degli Studi Orientali. Vol. 76. Pisa/Roma: Istituti Editoriali e Poligrafici Internazionali, 2003.

- - . "Ibn Taymiyya wa-jamā'atu-hu: Authority, Conflict and Consensus in Ibn Taymiyya's Milieu." Forthcoming in Ibn Taymiyya and His Times, ed. Shahab Ahmed and Yossef Rapoport. Karachi: Oxford University Press, 2007.

- - . "A new source for the biography of Ibn Taymiyya." Bulletin of the School of Oriental and African Studies 67.3 (2004): 321-348.

Brockelmann, Carl. Geschichte der arabischen Litteratur. Revised ed. 2 vols. Leiden: E.J. Brill 1943-9. Supplement. 3 vols. Leiden: E.J. Brill, 1937-1942.

- - Târīkh al-adab al-'arabī. Trans. Mahmūd Fahmī Hijāzī. Cairo: Al-Hay’a al-mișriyya al-'̄āmma li-l-kitāb, 1995. Trans. of Geschichte der arabischen Litteratur, revised ed., and supplement combined.

Brunschvig, R. "Devoir et pouvoir: Histoire d'un problème de théologie musulmane." Studia Islamica 20 (1964): 5-46. 
Bürgel, J. Christoph. “Zoroastrianism as Viewed in Medieval Islamic Sources." In Muslim Perceptions of Other Religions: A Historical Survey. Ed. Jacques Waardenburg, 202-212. Oxford, UK: Oxford University Press, 1999.

Calder, Norman. Review of Theodicy in Islamic Thought: The Dispute over al-Ghazälìs "Best of all Possible Worlds", by Eric L. Ormsby. Bulletin of the School of Oriental and African Studies 49 (1986): 211-2.

Cerić, Mustafa. Roots of Synthetic Theology in Isläm: A Study of the Theology of Abū Manșūr al-Māturììi (d. 333/944). Kuala Lumpur: International Institute of Islamic Thought and Civilization, 1995.

Ceylan, Yasin. Theology and Tafsir in the Major Works of Fakhr al-Din al-Räzī. Kuala Lumpur: International Institute of Islamic Thought and Civilization, 1996.

Chittick, William C. Imaginal Worlds: Ibn al-'Arabi and the Problem of Religious Diversity. Albany, NY: State University of New York Press, 1994.

- - The Self-Disclosure of God: Principles of Ibn al-'Arabi's Cosmology. Albany, NY: State University of New York Press, 1998.

- - The Sufi Path of Knowledge: Ibn al-Arabi's Metaphysics of Imagination. Albany, NY: State University of New York Press, 1989.

Cook, Michael. Commanding Right and Forbidding Wrong in Islamic Thought. Cambridge, UK: Cambridge University, 2000.

Dallal, Ahmad. "Ghazali and the Perils of Interpretation." Journal of the American Oriental Society 122.4 (2002): 773-787.

Davidson, Herbert A. Proofs for Eternity, Creation and the Existence of God in Medieval Islamic and Jewish Philosophy. Oxford, UK: Oxford University Press, 1987.

De Vlieger, A. Kitâb al qadr: Matériaux pour servir a l'étude de la doctrine de la prédestination dans la théologie musulmane. Leiden: E.J. Brill, 1903.

Delong-Bas, Natana J. Wabhabi Islam: From Revival and Reform to Global Jihad. Oxford, UK: Oxford University Press, 2004.

Diakho, Abou Ilyâs Mouhammed. Ibn Taymiya: Exposé de scolastique islamique (Ma'ârej al-wuçûl ila 'ilm al-uçül). Beirut: Dar Al-Bouraq, 1417/1996.

Fakhry, Majid. A History of Islamic Philosophy. 2d ed. New York, NY: Columbia University Press, 1983.

- - Ethical Theories in Islam. 2d ed. Leiden: E.J. Brill, 1994.

Flint, Thomas P. "Providence and predestination." In A Companion to Philosophy of Religion, ed. Philip L. Quinn and Charles Taliaferro, 569-576. Oxford, UK: Blackwell Publishers, 1997.

Frank, Richard M. “The Autonomy of the Human Agent in the Teaching of 'Abd al-Ğabbar." Le Muséon 95 (1982): 323-355.

- - Creation and the Cosmic System: Al-Ghazâlî and Avicenna. Heidelberg: Carl Winter Universitätsverlag, 1992.

-_. Al-Ghazàli and the Ash'arite School. Durham, NC: Duke University Press, 1994.

- - . "Moral Obligation in Classical Muslim Theology." The Journal of Religious Ethics 11.2 (1983): 204-223.

- - " "The structure of created causality according to al-Ašcarī. An analysis of the Kitāb al-Luma', pars. 82-164." Studia Islamica 25 (1966): 13-75.

Gardet, Louis. Dieu et la destinée de l'homme. Paris: J. Vrin, 1967.

Ghazālī (al-), Abū Hāmid. Ihyyà 'ulūm al-dìn. 5 vols. Beirut: Dār al-márifa, n.d.

- - The Incoherence of the Philosophers. Ar. ed. of Tahäfut al-faläsifa and trans. Michael E. Marmura. Provo, UT: Brigham Young University Press, 1997.

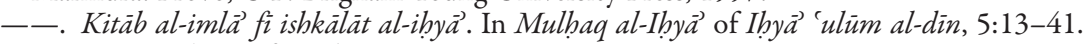
Beirut: Dār al-ma rifa, n.d.

- - Al-Maqșad al-asnā fì sharh mà ānī asmä Allāh al-ḥusnā. Ed. Fadlou A. Shehadi. Beirut: Dar el-Machreq, 1982.

Gimaret, Daniel. La doctrine d'al-Ash' arì. Paris: Cerf, 1990.

- - " "Un problème de théologie musulmane: Dieu veut-il les actes mauvais? Thèses et arguments." Studia Islamica 40 (1974): 5-73 and 41(1975): 63-92. 
- - "Théories de l'acte humain dans l'école Hanbalite." Bulletin d'études orientales 29

(1977): 156-178.

- - Théories de lacte humain en théologie musulmane. Paris: J. Vrin, 1980.

Gobillot, Geneviève. "L'Épître du discours sur la fitra (Risāla fì-l-kalām 'alā-l-fitra) de Taqi1-Dīn Ahmad Ibn Taymīya (661/1262-728/1328)." Annales Islamologiques 20 (1984): $29-53$.

- - La fitra: la conception originelle: ses interprétations et fonctions chez les penseurs musulmans. Cairo: Institut français d'archéologie orientale, 2000.

Goldziher, Ignaz. Introduction to Islamic Theology and Law. Trans. Andras and Ruth Hamori. Princeton, NJ: Princeton University Press, 1981.

- - The Zähiris: their doctrine and their history. Trans. and ed. Wolfgang Behn. Leiden: Brill, 1971. Trans. of Die Zähiriten, Leipzig, 1884.

Goodman, Lenn E. Avicenna. London: Routledge, 1992.

Graham, William A. Divine Word and Prophetic Word in Early Islam. The Hague: Mouton, 1977.

Griffel, Frank. "Al-Gazālī’s Concept of Prophecy: The Introduction of Avicennan Psychology Into Ašrarite Theology." Arabic Sciences and Philosophy 14 (2004): 101-144.

Gutas, Dimitri. “The Heritage of Avicenna: the Golden Age of Arabic Philosophy, 1000-ca. 1350." In Avicenna and His Heritage, ed. J. Janssens and D. DeSmet, 81-97. Leuven: Leuven University Press, 2002.

- - " "The Study of Arabic Philosophy in the Twentieth Century: An Essay on the Historiography of Arabic Philosophy." British Journal of Middle Eastern Studies 29 (2002): 5-25.

Gwynne, Rosalind W. "Al-Jubbā'ī, al-Ash'arī and the Three Brothers: The Uses of Fiction." The Muslim World 75 (July-Oct. 1985): 132-161.

Hallaq, Wael B. Ibn Taymiyya against the Greek Logicians. Oxford, UK: Clarendon Press, 1993.

- - "Ibn Taymiyya on the Existence of God." Acta Orientalia 52 (1991): 49-69.

- - . A History of Islamic Legal Theories: An introduction to Sunnī uṣul al-fiqh. Cambridge, UK: Cambridge University, 1997.

Haque, Serajul. "Ibn Taymiyyah: A Life and Works." In A History of Muslim Philosophy. Ed. M.M. Sharif, 2:796-819. Wiesbaden: Otto Harrossowitz, 1966.

-_. Imām Ibn Taimiya and his projects of reform. Dhaka: Islamic Foundation, 1982.

- - . "A Letter of Ibn Taymiyya to Abū l-Fidāà." In Documenta Islamica Inedita, ed, Johann W. Fück, 155-161. Berlin: Akademie-Verlag, 1952.

- - . "A Poem of Imām Ibn Taymiyya on Predestination." Journal of the Asiatic Society (Pakistan) 1 (1956): 1-17.

-_. "Su'al li Ibn Taymiyya." Journal of the Asiatic Society (Pakistan) 2 (1957): 154-173.

Heck, Paul L. "Jihad Revisited." Journal of Religious Ethics 32 (2004): 95-128.

Heemskerk, Margaretha T. Suffering in Mu'tazilite Theology: 'Abd al-Jabbär's Teaching on Pain and Divine Justice. Leiden: Brill, 2000.

Heer, Nicholas. "The Priority of Reason in the Interpretation of Scripture: Ibn Taymiyah and the Mutakallimūn." In Literary Heritage of Classical Islam: Arabic and Islamic Studies in Honor of James A. Bellamy, ed. Mustansir Mir, 181-195. Princeton, NJ: The Darwin Press, 1993.

- - "Al-Rāzī and al-Ṭūsī on Ibn Sīnās Theory of Emanation." In Neoplatonism and Islamic Thought, ed. Parviz Morewedge, 111-125. Albany, NY: State University of New York Press, 1992.

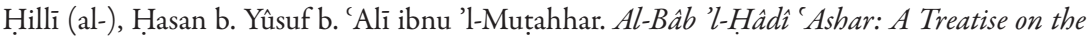
Principles of Shî̀ ite Theology with Commentary by Miqdâd-l-Fâdil al-Hillì. Trans. William McElwee Miller. London: The Royal Asiatic Society, 1928.

Homerin, Th. Emil. "Ibn Taimīya's Al-Sufiyya wa-al-fuqarä.”. Arabica 32 (1985): 219-244.

_- . "The Study of Islam within Mamluk Domains." Mamlük Studies Review 9.2 (2005): $1-30$. 
Hoover, Jon. “God Acts by His Will and Power: Ibn Taymiyya’s Theology of a Personal God in his Treatise on the Voluntary Attributes." Forthcoming in Ibn Taymiyya and His Times, ed. Shahab Ahmed and Yossef Rapoport. Karachi: Oxford University Press, 2007.

- - "Ibn Taymiyya as an Avicennan Theologian: A Muslim Approach to God's Self-Sufficiency." Theological Review of the Near East School of Theology 27.1 (April 2006): 34-46.

- - "The Justice of God and the Best of All Possible Worlds: The Theodicy of Ibn Taymiyya." Theological Review of the Near East School of Theology 27.2 (November 2006): $53-75$.

- - "Perpetual Creativity in the Perfection of God: Ibn Taymiyya's Hadith Commentary on God's Creation of this World," Journal of Islamic Studies 15:3 (Sept. 2004): 287-329.

- - Review of Ibn 'Arabi in the Later Islamic Tradition: The Making of a Polemical Image in Medieval Islam, by Alexander D. Knysh. Islam and Christian-Muslim Relations 10:3 (Oct. 1999): 392-4.

Hourani, George F. “Averroes on Good and Evil." Studia Islamica 16 (1962): 13-40.

- - "Ibn Sinās 'Essay on the Secret of Destiny." Bulletin of the School of Oriental and African Studies 29 (1966): 25-48.

- - Islamic Rationalism: The Ethics of 'Abd al-Jabbār. Oxford, UK: Clarendon Press, 1971.

Hussain, Mohammed Yusoff. "Al-Ash'arìs Discussion of the Problem of Evil.” Islamic Culture 64:1 (1990): 25-38.

Ibn 'Abd al-Hādī, Muhammad b. Ahmmad. Al-'Uqūd al-durriyya min manāqib Shaykh al-Islam Aḅmad b. Taymiyyá. Beirut: Dār al-kutub al-ilmiyya, n.d.

Ibn al-Dawādārī, Abū Bakr b. 'Abd Allāh. Kanz al-durar wa jāmi' al-ghurar. Vol. 9, Al-Durar al-fäkhir fì sìrat al-Malik al-Nāsirir. Ed. Hans Robert Roemer. Cairo: Qism al-dirāsāt alislāmiyya bi-l-ma'had al-almānī li-l-āthār bi-l-Qāhira, 1960.

Ibn al-Jawzī, 'Abd al-Rahmān. The Attributes of God (Daf' Shubah al-Tashbīh bi-Akaff alTanzīh). Trans. 'Abdullāh bin Hamīd 'Alī. Bristol, UK: Amal Press, 2006.

Ibn 'Arabī al-Hātimī al-Ṭāòi. Al-Futūhāt al-Makkiyya. 4 vols. Beirut: Dār Șādir, n.d.

Ibn 'Arabī, Muhyī al-Dīn. Fuṣūs al-hikam. Ed. and commentary by Abū al-'Alä' 'Afîfì. Beirut: Dār al-kitāb al-'arabī, n.d.

Ibn Hanbal, Aḥmad. Al-Radd 'alā al-zanädiqa wa al-Jahmiyya. Ed. Muhammad Hasan Rāshid. Cairo: al-Mațba'a al-salafiyya, 1393/1973-4.

Ibn Kamāl Bāshā, Shams al-Dīn Aḥmad b. Sulaymān. Rasā’il Ibn Kamāl. 2 parts in 1 vol. Istanbul: Mațaba'at Iqdām, 1316/1898-9.

Ibn Kathīr, Abū al-Fidā'. Al-Bidāya wa al-nihāya fì al-tàrīkh. Ed. Aḥmad Abū Mulhim, et al. 14 vols. Beirut: Dār al-kutub al-'ilmiyya, 1407/1987.

Ibn Qayyim al-Jawziyya, Shams al-Dīn. Asmä mu'allafāt Ibn Taymiyya. Ed. Salāh al-Dīn al-Munajjid. Damascus: Matbū'āt al-majma' al-'ilmī al-'arabī, 1953. Reattributed to Abū 'Abd Allāh Muhammad b. 'Abd Allāh b. Aḥmad Sibṭ b. Rushayyiq al-Mālikī by Shams and 'Imrān, Al-jāmi', 8-13, and reedited therein with additions, 220-249.

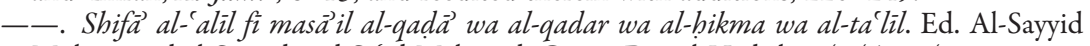
Muhammad al-Sayyid and Sa ${ }^{\top} \overline{1} d$ Mahmūd. Cairo: Dār al-Hadīth, 1414/1994.

Ibn Qudāma al-Maqdisi, Muwaffaq al-Dīn. Tahrìm al-nazar fì kutub al-kalām. Ed. 'Abd alRaḥmān b. Muhammad Sa '̄ìd Dimashqiyya. Riyadh: Dār 'ālam al-kutub, 1990.

Ibn Rajab. Kitāb al-dhayl 'alā țabaqāt al-ḥanābila. 2 vols. Cairo: Maṭba'at al-sunna almuhammadiyya, 1372/1953.

Ibn Rushd (Averroes). Kitāb faṣl al-maqāl with its appendix (Damìma) and an extract from Kitāb al-kashf' an manāhij al-adilla. Ed. George F. Hourani. Leiden: E.J. Brill, 1959.

- - . On the Harmony of Religion and Philosophy: A translation, with introduction and notes, of Ibn Rushd's Kitāb fasl al-maqāl, with its appendix (Damima) and an extract from Kitāb al-kashf' an manāhij al-adilla. Trans. George F. Hourani. London: Luzac, 1961.

Ibn Sīnā. Al-Ishārāt wa al-tanbīhāt. Ed. Sulaymān Dunyā. 3 vols. Cairo: Dār iḥyāa al-kutub al-'arabiyya, 1366-7/1947-8. 
Al-Mabda' wa al-ma'ād. Ed. 'Abd Allāh Nūrānī. Tehran: Institute of Islamic Studies,

McGill University-Tehran University, 1984.

——. Al-Najāh. Cairo: Maṭba'at al-sa āda, 1331/1913.

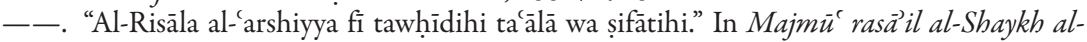
Ra'ì Abī' Alī al-Husayn b. 'Abd Allāh b. Siña al-Bukhārì. Haydarābād al-Dakkan: Maṭba'at jam iyyat dāirirat al-ma'ārif al-'uthmāniyya, 1354/1935-6.

_- . Risāla fì sirr al-qadar. See George F. Hourani, "Ibn Sīnās 'Essay on the Secret of Destiny."'

-—. Al-Shifäà Al-Ilāhiyyāt (1). Ed. Ibrāhīm Madkūr, et al. Cairo: Al-Hay’a al-āmma lishu'ūn al-matābi' al-amīiryya, 1380/1960.

-—. Al-Shifä̀̃ :Al-Ilāhiyyāt (2). Ed. Muhammad Yūsuf Mūsā, et al. Cairo: Al-Hay’a al-āmma li-shu'ūn al-mațābi' al-amīriyya, 1380/1960.

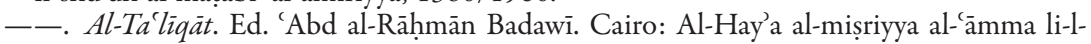
kitāb, 1973.

Inati, Shams C. The Problem of Evil: Ibn Sînâs' Theodicy. Binghamton, NY: Global Publications, Institute of Global Cultural Studies, Binghamton University, 2000.

İskenderoğlu, Muammer. Fakhr al-Din al-Räzi and Thomas Aquinas on the Question of the Eternity of the World. Leiden: Brill, 2002.

Ivry, Alfred L. "Destiny Revisited: Avicenna’s Concept of Determinism." In Islamic Theology and Philosophy: Studies in Honor of George F. Hourani. Ed. Michael E. Marmura, 160-171. Albany, NY: State University of New York Press, 1984.

Jackson, Sherman A. "Ibn Taymiyyah on Trial in Damascus." Journal of Semitic Studies 39 (Spring 1994): 41-85.

- - Islamic Law and the State: The Constitutional Jurisprudence of Shihäb al-Din al-Qaräfì. Leiden: Brill, 1996.

Jansen, Johannes J.G. "Ibn Taymiyyah and the Thirteenth Century: A Formative Period of Modern Muslim Radicalism." Quaderni di Studi Arabi 5-6 (1987-8): 391-6.

Jilānī (al-), 'Abdul-Qādir. Revelations of the Unseen (Futūḥ al-Ghaib). Trans. Muhtar Holland. Houston, TX: Al-Baz, 1992.

Julaynad (al-), Muhammad al-Sayyid. Al-Imām Ibn Taymiyya wa mawqifubu min qadiyyat al-ta’wīl. Cairo: Al-Hay’a al-āmma li-shu'ūn al-matābi al-amīriyya, 1393/1973.

- - Qadiyyat al-khayr wa al-sharr fí al-fikr al-islàmì: Ușüluha al-nazariyya-jawānibuha altațbiquiyya, Dirāsa 'ilmiyya li-mas'üliyyat al-insān fì al-Isläm. 2d Printing. Cairo: Maṭba'at al-Halabī, 1981.

Juwaynī (al-), Imām al-Haramayn Abū al-Ma ālī 'Abd al-Malik. Al-'Aqìda al-nizämiyya. Ed. Muhammad Zāhid al-Kawtharī. [Cairo]: Matba'at al-anwār, 1368/1948.

Juwaynī (al-), Imām al-Haramayn 'Abd al-Malik b. 'Abd Allāh. Kitāb al-irshād ilā qawātị' al-adilla fì usūul al-i'tiqäd. Beirut: Dār al-Kutub al-ilmiyya, 1416/1995.

Khalidi, Tarif. Arabic historical thought in the classical period. Cambridge, UK: Cambridge University, 1994.

Khan, Qamaruddin. The Political Thought of Ibn Taymiyya. India: Adam, 1988.

Khayyāt (al-), Abū al-Husayn 'Abd al-Rahmān b. Muhammad b. 'Uthmān. Kitāb al-intișār. Ed. H.S. Nyberg with French trans. by Albert N. Nader. Beirut: Les lettres orientales, 1957.

Knysh, Alexander D. Ibn 'Arabi in the Later Islamic Tradition: The Making of a Polemical Image in Medieval Islam. Albany, NY: State University of New York Press, 1999.

Kutubī (al-), Muḥammad b. Shākir. Fawāt al-wafayyāt wa al-dhayl 'alayhā. Ed. Iḥsān 'Abbās. 5 vols. Beirut: Dār Șādir, 1973.

Lane, E.W. Arabic-English Lexicon. 2 vols. Cambridge, UK: Islamic Texts Society, 1984.

Laoust, Henri. "La biographie d'Ibn Taimìya d'après Ibn Katīir." Bulletin d'etudes orientales $9(1942-3): 115-162$.

- - Contribution à une étude de la méthodologie canonique d'Ibn Taymiyya. Cairo: Institut français d'archéologie orientale, 1939.

- _. "La critique du Sunnisme dans la doctrine d'Al-Hillī." Revue des études islamiques 34 (1966): 35-60. 
- - Essai sur les doctrines sociales et politiques de Taki-d-Din Abmad b. Taimìya, canoniste hanbalite né à Harrān en 661/1262, mort à Damas en 728/1328. Cairo: Imprimerie de l'institute français d'archéologie orientale, 1939.

- - . "Une fetwà d'Ibn Taimìya sur Ibn Tümart." Bulletin de l'institute française d'archeologie orientale 59 (1960): 157-184.

- - "Le hanbalisme sous les Mamlouks Bahrides (658-784/1260-1382)." Revue des études islamiques 28 (1960): 1-71.

- - . "L'influence d'Ibn-Taymiyya." In Islam: Past Influence and Present Challenge. Ed. Alford T. Welch and Pierre Cachia, 15-33. Edinburgh: Edinburgh University Press, 1979.

- - "Le premières professions de foi hanbalites." Mélanges Louis Massignon 3 (1957): 7-35.

- - La profession de foi d'Ibn Taymiyya: Texte, traduction et commentaire de la Wāsitiyya. Paris: Librairie Orientaliste Paul Geuthner, 1986.

_- "Le reformisme d'Ibn Taymiya." Islamic Studies (Karachi) 1:3 (Sept. 1962): 27-47.

- _. "Quelques opinions sur la théodicée d'Ibn Taimiya." Melanges Maspero. Vol. 3, Orient Islamique, 431-8. Cairo: Imprimerie de l'institute français d'archéologie orientale, 1935-40.

- - Les schismes dans l'Islam. Paris: Payot, 1965.

- - Le traité de droit public d'Ibn Taymiyya. Damascus: Institut français de Damas, 1948.

Leibniz, G. W. Theodicy: Essays on the Goodness of God, the Freedom of Man, and the Origin of Evil. Trans. E.M. Huggard. London: Routledge and Kegan Paul, 1951.

Little, Donald Presgrave. "Did Ibn Taymiyya have a Screw Loose?" Studia Islamica 41 (1975): 93-111.

- - " "The Historical and Historiographical Significance of the Detention of Ibn Taymiyya." International Journal of Middle East Studies 4 (1973): 311-327.

- - An Introduction to Mamlük Historiography: An Analysis of Arabic Annalistic and Biographical Sources for the Reign of al-Malik an-Nāsir Muhammad ibn Qaläūn. Wiesbaden: Franz Steiner Verlag, 1970.

Lovejoy, Arthur O. The Great Chain of Being: A Study of the History of an Idea. Cambridge, MA: Harvard University Press, 1936.

Madelung, Wilferd. “The Late Mu'tazila and Determinism: The Philosopher's Trap." In Yäd-nàma in memoria di Alessandro Bausani, ed. Biancamaria Scarcia Amoretti and Lucia Rostagno, vol. 1, Islamistica, 245-257. Rome: Bardi, 1991.

Madjid, Nurcholish. "Ibn Taymiyya on Kalām and Falsafa: A problem of Reason and Revelation in Islam." Ph.D. diss., University of Chicago, 1985.

Makari, Victor E. Ibn Taymiyyah's Ethics: The Social Factor. Chico, CA: Scholars Press, 1983.

Makdisi, George. "Ash'arī and the Ash'arites in Islamic Religious History." Studia Islamica 17 (1962): 37-80 and 18 (1963): 19-39. Reprint as Part I in Religion, Law and Learning in Classical Islam. Hampshire, UK: Variorum, 1991.

- - "Ethics in Islamic Traditionalist Doctrine." In Ethics in Islam, ed. Richard G. Hovannisian, 47-63. Malibu, CA: Undena, 1985. Reprint as Part IV in Religion, Law and Learning in Classical Islam. Hampshire, UK: Variorum, 1991.

- - . "The Hanbali School and Sufism." Boletin de la Asociacion Espanola de Orientalistas. 15 (1979): 115-126. Reprint as Part V in Religion, Law and Learning in Classical Islam. Hampshire, UK: Variorum, 1991.

_- "Hanbalite Islam." In Studies in Islam. Trans. and ed. Merlin L. Swartz, 216-274. New York: Oxford University Press, 1981.

- - Ibn 'Aqïl: Religion and Culture in Classical Islam. Edinburgh: Edinburgh University Press, 1997.

——. "Ibn Taimīya: A Șūfi of the Qādiriya Order." American Journal of Arabic Studies. 1 (1973): 118-129.

——. Ibn Qudàma's Censure of Speculative Theology. London: Luzac, 1962. 
Makkī (al-), Abū Tāàlib. Qüt al-qulüb. 2 vols. n.pl.: n.p., n.d.

Marcotte, Roxanne D. "Ibn Taymiyya et sa critique des produits de la faculté d'estimation (Wahmiyyāt) dans le Dar' ta'äruḍ al-'aql wa al-naql." Luqmān 18.2 (2002): 43-58.

Marmura, Michael E. "Ghazali and Ash'arism Revisited." Arabic Sciences and Philosophy 12 (2002): 91-110.

- - "Ghazālian Causes and Intermediaries." Journal of the American Oriental Society 115 (1995): 89-100.

- - "Ghazali's Chapter on Divine Power in the Iqtisäd." Arabic Sciences and Philosophy 4 (1994): 279-315.

Massignon, Louis. The Passion of al-Halläj: Mystic and Martyr of Islam. Trans. Herbert Mason. Princeton, NJ: Princeton University Press, 1982.

Matroudi (al-), Abdul Hakim I. The Hanbali School of Law and Ibn Taymiyyah: Conflict or Conciliation. London: Routledge, 2006.

Māturīìi (al-), Abū Manșūr. Kităb al-tawhìd. Ed. Fath Allāh Khulayf. Alexandria: Dār aljāmi'āt al-mișriyya, n.d.

McCarthy, Richard J. The Theology of al-Ash'arì. Beirut: Imprimerie Catholique, 1953.

McDermott, Martin J. The Theology of al-Shaikh al-Mufid (d. 413/1022). Beirut: Dar elMachreq, 1978.

Meier, Fritz. "The Cleanest about Presdestination: A Bit of Ibn Taymiyya." In Essays on Islamic Piety and Mysticism. Trans. John O'Kane, 309-334. Leiden: Brill, 1999. Trans. of "Das sauberste über die vorbestimmung: Ein stück Ibn Taymiyya." Saeculum 32 (1981): 74-89.

Memon, Muhammad Umar. Ibn Taimiya's Struggle Against Popular Religion: With an Annotated Translation of his Kitāb iqtiḍāa aṣ-șirāṭ al-mustaqìm mukhālafat aṣhāb al-jahịm. The Hague: Mouton, 1976.

Michel, Thomas F. “Ibn Taymiyya: Islamic Reformer." Studia Missionalia 34 (1985): 213232.

_- . "Ibn Taymiyya's Critique of Falsafa." Hamdard Islamicus 6:1 (Spring 1983): 3-14.

- - "Ibn Taymiyyàs Sharḥ on the Futūh al-ghayb of 'Abd Al-Qādir Al-Jilānī." Hamdard Islamicus 4:2 (Summer 1981): 3-12.

- - . A Muslim Theologian's Response to Christianity: Ibn Taymiyya's Al-Jawab Al-Sahih. Delmar, NY: Caravan Books, 1984.

Michot, Yahya J. [Jean R. Michot; Yahya M. Michot] Avicenne: Réfutation de l'astrologie. Beirut: Les éditions al-Bouraq, 1427/2006.

- - "Un célibataire endurci et sa maman: Ibn Taymiyya (m. 728/1328) et les femmes." Acta Orientalia Belgica 15 (2001): 165-190.

_- La destinée de l'homme selon Avicenne. Louvain: Peeters, 1986.

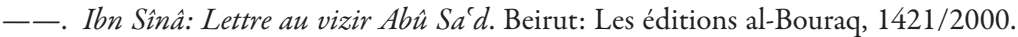

- - . "Ibn Taymiyya on Astrology: Annotated Translation of Three Fatwas." Journal of Islamic Studies 11.2 (2000): 147-208.

-_. Ibn Taymiyya: Un Dieu hésitant? Beirut: Dar Al-Bouraq, 1425/2005.

- - . "Ibn Taymiyya: Les intermédiaires entre Dieu et l'homme (Risâlat al-wâsita bayna l-khalq wa l-haqq)." Le Musulman (Paris) Special Issue (1996).

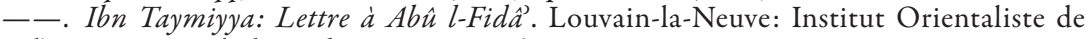
l'Université Catholique de Louvain, 1994.

- - Ibn Taymiyya: Lettre à un roi croisé (Al-Risâlat al-Qubrusiyya). Louvain-la-Neuve: Bruylant-Academia, 1995.

- - Ibn Taymiyya: Mardin: Hégire, fuite du péché et «demeure de l'Islam». Beirut: Dar Al-Bouraq, 1425/2004.

- - . "A Mamlūk Theologian's Commentary on Avicenna’s Risāla Aḍhawiyya: Being a Translation of a Part of the Dar' al-Ta'a arud of Ibn Taymiyya, With Introduction, Annotation, and Appendices." Journal of Islamic Studies 14 (2003): 149-203 (Part I) and 309-363 (Part II). 
-_. Musique et danse selon Ibn Taymiyya: Le livre du samâc et de la danse (Kitâb al-Samấ wa l-Raqs) compilé par le shaykh Muhammad al-Manbijī. Paris: J. Vrin, 1991.

- - "Pages spirituelles d'Ibn Taymiyya: II. La religion du milieu." Action (Mauritius)

(December 1999), 22-23, 30.

- - "Pages spirituelles d'Ibn Taymiyya: IX. La finalité du coeur." Action (Mauritius) (July 2000), 18-19, 26.

- _. "Pages spirituelles d'Ibn Taymiyya: X. L'amour et la Voie (sharî‘ a)." Action (Mauritius) (August 2000), 18-19.

- - . "Pages spirituelles d'Ibn Taymiyya: XIII. Contre l'astrologie." Action (Mauritius) (January 2001), 10-11, 26.

- - “Textes Spirituels d'Ibn Taymiyya: I. L'extinction ( fanâa)." Le Musulman (Paris) 11 (1990): 6-9, 29.

- - " "Textes Spirituels d'Ibn Taymiyya: II. L'étre (kawn) et la religion (dîn)." Le Musulman (Paris) 13 (1990-1): 7-10, 28.

- - " "Textes Spirituels d'Ibn Taymiyya: III. La servitude ('ubûdiyya): de l'asservissement à l'adoration de Dieu." Le Musulman (Paris) 14 (1991): 8-11.

- - " "Textes Spirituels d'Ibn Taymiyya: IV. Entre la divinité et la seigneurialité, le polymorphisme de l'associationnism (shirk)." Le Musulman (Paris) 16 (1991): 8-13.

- - . "Textes Spirituels d'Ibn Taymiyya: VII. La servitude d'adoration, ou la perfection dans la liberté du coeur." Le Musulman (Paris) 20 (1992): 10-15.

- - "Textes Spirituels d'Ibn Taymiyya: X. «Je ne suis dans cette affaire qu'un musulman parmi d'autres...»." Le Musulman (Paris) 23 (1994): 27-32.

- - . "Vanités intellectuelles... L'impasse des rationalismes selon le Rejet de la contradiction d'Ibn Taymiyyah." Oriente Moderno 19 (2000): 597-617.

Momen, Moojan. An Introduction to Shi' $i$ Islam: The History and Doctrines of Twelver Shi ism. New Haven, CT: Yale University Press, 1985.

Monnot, Guy. Islam et religions. Paris: Éditions Maisonneuve et Larose, 1986.

- - Penseurs musulmans et religions iraniennes: 'Abd al-Jabbär et ses devanciers. Paris: Librairie philosophique J. Vrin, 1974.

Moosa, Ebrahim. Ghazāli and the Poetics of Imagination. Chapel Hill, NC: The University of North Carolina Press, 2005.

Morabia, Alfred. "Ibn Taymiyya, Les Juifs et la Tora." Studia Islamica 49 (1979): 91-122 and $50(1979[\mathrm{sic}]): 77-107$.

- - "Prodiges prophétiques et surnaturel démoniaque selon Ibn Taymiyya." In La signification du bas moyen âge dans l'histoire et la culture du monde musulman [pprs. 8th Cong. UEAI Sept. 1976), ed. Ihsān Abbās, et al., 161-172. Aix-en-Provence, France: Edisud, 1978.

Murad, Hasan Qasim. "Ibn Taymiya on Trial: A Narrative Account of his Mihan." Islamic Studies 18 (1979): 1-32.

Murata, Sachiko. The Tao of Islam. Albany, NY: State University of New York Press, 1992.

Nagel, Tilman. The History of Islamic Theology: From Muhammad to the Present. Trans. Thomas Thornton. Princeton, NJ: Markus Wiener Publishers, 2000.

Nasr, Seyyed Hossein, and Oliver Leaman, eds. History of Islamic Philosophy. London: Routledge, 1996.

Netton, Ian Richard. Allah Transcendent. Richmond, Surrey, UK: Curzon Press, 1989.

Nwyia, P. "Une cible d'Ibn Taimîya: Le moniste al-Tilimsânî (m. 690/1291)." Bulletin d'Etudes orientales 30 (1978): 127-145.

Olesen, Niels Henrik. Cultes des Saints et Pélerinages chez Ibn Taymiyya. Paris: Paul Geuthner, 1991.

- - . "Étude comparée des idées d'Ibn Taymiyya (1263-1328) et de Martin Luther (14831546) sur le culte des saints." Revue des Etudes Islamiques. 50 (1982): 175-206.

Opwis, Felicitas. "Maslaha in Contemporary Islamic Legal Theory." Islamic Law and Society 12.2 (2005): 182-223. 
Ormsby, Eric L. Theodicy in Islamic Thought: The Dispute over al-Ghazälìs "Best of all Possible Worlds." Princeton, NJ: Princeton University Press, 1984.

Otten, Henry J. "The Problem of Evil in Islam." Bulletin of Christian Institutes of Islamic Studies 8:1 (Jan.-March 1985): 1-23.

Pavlin, James. "The Concept of 'Ubüdiyyah in the Theology of Ibn Taymiyyah: The Relationship between Faith, Love and Actions in the Perfection of Worship." Ph.D. diss., New York University, 1998.

Perho, Irmeli. "Man Chooses his Destiny: Ibn Qayyim al-Jawziyya's view on predestination." Islam and Christian-Muslim Relations 12 (2001): 61-70.

Perlmann, Moshe. "Ibn Qayyim and the Devil." In Studi Orientalistici in onore di Giorgio Levi della Vida, vol. 2, 330-7. Rome: Istituto per l'oriente, 1956.

Pessagno, J. Meric. "Irāda, Ikhtiyār, Qudra, Kasb: The View of Abū Manșūr Al-Māturīdī." Journal of the American Oriental Society 104 (1984): 177-191.

_- ". "The uses of Evil in Maturidian Thought." Studia Islamica 60 (1984): 59-82.

Quinn, Philip L., and Charles Taliaferro, eds. A Companion to Philosophy of Religion. Oxford, UK: Blackwell Publishers, 1997.

Rahman, Fazlur. Islam. 2d ed. Chicago: University of Chicago Press, 1979.

- - Prophecy in Islam: Philosophy and Orthodoxy. London: George Allen \& Unwin, 1958.

-—. Revival and Reform in Islam: A Study of Islamic Fundamentalism. Oxford: Oneworld Publications, 2000.

Rashed, Marwan. "Théodicée et approximation: Avicenne." Arabic Sciences and Philosophy 10 (2000): 223-257.

Rāzī (al-), Fakhr al-Dīn. Al-Arba' in fì usūul al-dìn. Ed. Aḥmad Hijāzī al-Saqā. Cairo: Maktabat al-kulliyyāt al-azhariyya, n.d.

- - Kitāb al-mabāhith al-mashriqiyya. 2 vol. Hyderabad: Maṭba'at majlis dāirirat al-ma'ārif al-nizāmiyya, 1343/1924.

-—. Al-Matạlib al-'äliyya min al-'ilm al-ilähī. Ed. Aḥmad Hijāzī al-Saqā. 9 parts in 5 vols. Beirut: Dār al-kitāb al-'arabīi, 1407/1987.

- - Muhasșal afkār al-mutaqaddimin wa al-muta' akbkhirin min al-'ulamä wa al-hukamä wa al-mutakallimin. Ed. Țāhā 'Abd al-Ra’ūf Sa'd. Cairo: Maktabat al-kulliyyāt al-azhariyya, n.d.

-C. Al-Tafsìr al-kabìr li-l-Imām al-Fakhr al-Rāzì. Cairo: Mu'assasat al-maṭbūeàt al-islāmī, n.d.

Ṣafadī (al-), Ṣalāḥ al-Dīn Khalīl b. Aybak. Kitāb al-wāfî̀ bi-l-wafayāt. Vol. 7. Ed. Iḥsān 'Abbās. Wiesbaden: Franz Steiner, 1969.

Ṣaghīr (al-), 'Abd al-Majīd. "Mawāqif rushdiyya li-Taqī al-Dīn Ibn Taymiyya? Mulāhazāāt awwaliyya." In Dirāsāt maghribiyya muhdāt ilā al-mufakkir al-maghribī Muhammad 'Azīz al-Habbäbì, 93-117. Rabat: n.p., 1985. 2d ed., 164-182. Rabat: n.p., 1987.

Schimmel, Annemarie. Mystical Dimensions of Islam. Chapel Hill, NC: The University of North Carolina Press, 1975.

Schmidtke, Sabine. The Theology of al-' Alläma al-Hillī (d. 726/1325). Berlin: Klaus Schwarz, 1991.

Schwarz, M. “'Acquisition' (Kasb) in early Kaläm." In Islamic Philosophy and the Classical Tradition: Essays presented by his friends and pupils to Richard Walzer on his seventieth birthday, ed. S.M. Stern, Albert Hourani, and Vivian Brown, 355-387. Columbia, SC: University of South Carolina Press, 1973.

Seale, Morris S. Muslim Theology: A Study of Origins with Reference to the Church Fathers. London: Luzac, 1964.

Shahrastānī (al-), Muhammad b. 'Abd al-Karīm. Kitäb nihāyatu 'l-iqdām fì 'ilmi 'l-kalām. Ed. with trans. Alfred Guillaume. London: Oxford University Press, 1934.

- - . Al-Milal wa al-niḩal. Ed. Ahmmad Fahmī Muhammad. Beirut: Dar al-kutub al-ilmiyya, n.d. 
Shahrastānī, Muhammad b. 'Abd al-Karīm. Muslim Sects and Divisions: The Section on Muslim Sects in Kitāb al-Milal wa 'l-Nihal. Trans. A.K. Kazi and J.G. Flynn. London: Kegan Paul, 1984.

Shahrastani. Livres des religions et des sectes. Trans. Daniel Gimaret and Guy Monnot. Louvain: Peeters, 1986.

Shāmī (al-), Rizq Yūsuf. "Ibn Taymiyya: Maṣādiruhu wa manhajuhu fī taḥlīlihā." Majallat Ma'had al-makhtūtāt al-'arabiyya 38 (1994): 183-269.

Shams, Muhammad 'Uzayr and Alī b. Muhammad 'Imrān, eds. Al-Jāmi' li-sìrat Shaykh alIsläm Ibn Taymìya (661-728) khiläl sab' at qurūn. With an introduction by Bakr b. 'Abd Allāh Abū Zayd. Mecca: Dār 'ālam al-fawā'id, 1420/1999-2000.

Shihadeh, Ayman. "From al-Ghazālì to al-Rāzì: 6th/12th Century Developments in Muslim Philosophical Theology." Arabic Sciences and Philosophy 15 (2005): 141-179.

- - The Teleological Ethics of Fakhr al-Din al-Räzī. Leiden: Brill, 2006.

Sivan, Emmanuel. "Ibn Taymiyya: Father of the Islamic Revolution: Medieval Theology \& Modern Politics.” Encounter 60.5 (May 1983): 41-50.

Stieglecker, Hermann. "Die islamische Lehre vom Guten und Bösen.” Orientalia 4 (1935): 239-245.

Stroumsa, Sarah, and Gedaliahu G. Stroumsa. "Aspects of Anti-Manichaean Polemics in Late Antiquity and under Early Islam." Harvard Theological Review 81:1 (1988): 37-58.

Stroumsa, Sarah. Freethinkers in Medieval Islam: Ibn al-Rāwandī, Abū Bakr al-Rāzì, and Their Impact on Islamic Thought. Leiden: Brill, 1999.

Swartz, Merlin. A Medieval Critique of Anthropomorphism: Ibn al-Jawzīs Kitāb Akhbār aș-Ṣifāt: A Critical Edition of the Arabic Text with Translation, Introduction and Notes. Leiden: Brill, 2002.

——. "A seventh-century (A.H.) Sunnī creed: The 'Aqīda Wāsițiya of Ibn Taymìya." Humaniora Islamica 1 (1973): 91-131.

Tabarī (al-), Abū Ja'far Muhammad b. Jarīr. Tafsìr al-Ṭabarī: Jāmi al-bayān 'an ta'wīl āyy al-Qur'ān. Ed. Maḥmūd Muḥammad Shākir. Cairo: Dār al-Ma'ārif bi-maṣr, n.d.

Tritton, A.S. Muslim Theology. London: Luzac, 1947.

Vajda, G. "Le Témoignage d’al-Māturidī sur la doctrine des Manichéens, des Dayṣānites et des Marcionites." Arabica 13 (1966): 1-38, 113-128.

Van Nispen Tot Sevenaer, Christian. Activité Humaine et Agir de Dieu: Le Concept de 'Sunan de Dieu' dans le commentaire coranique du Manar. Beyouth: Dar el-Machreq, 1996.

Vasalou, Sophia. "Equal Before the Law: The Evilness of Human and Divine Lies: 'Abd alĞabbār's Rational Ethics.” Arabic Sciences and Philosophy 13 (2003): 243-268.

Von Grunebaum, G.E. “Observations on the Muslim Concept of Evil.” Studia Islamica 31 (1970): 117-134.

Watt, W. Montgomery. The Formative Period of Islamic Thought. Edinburgh: Edinburgh University Press, 1973.

——. Islamic Creeds: A Selection. Edinburgh: Edinburgh University Press, 1994.

- _. "Suffering in Sunnite Islam." Studia Islamica 50 (1979): 5-19.

Wein, Clemens. Die Islamische Glaubenslehre ('Aqida) des Ibn Taimìya. Bonn: n.p., 1973.

Williams, Wesley. "Aspects of the Creed of Imam Ahmad Ibn Hanbal: A Study of Anthropomorphism in Early Islamic Discourse." International Journal of Middle East Studies 34 (2002): 441-463.

Wisnovsky, Robert. Avicenna's Metaphysics in Context. Ithaca, NY: Cornell University Press, 2003.

Wolfson, Harry Austryn. The Philosophy of the Kalam. Cambridge, MA: Harvard University Press, 1976.

Young, M.J.L. “The Treatment of the Principle of Evil in the Qur'ān.” Islamic Studies 5 (1966): 275-281.

Zamakhsharī (al-), Abū al-Qāsim Jār Allāh. Al-Kashshāf. Beirut: Dār al-kutub al-ilmiyya, $1415 / 1995$. 



\section{INDEX}

a fortiori argument (qiyās al-awlā) (see highest similitude)

Aaron 125

'Abd al-Jabbār (d. 415/1025) 113 n. 63, 142, 177, 202 n. 98,213 n. 14

'Abd al-Qādir al-Jilānī (d. 561/1166) 110

ability (țāqa) 147-8, 165-9

Abraham 38, 63, 146, 180-1

Abrahamov, Binyamin 29-30, 140 n. 13, 141

Abū al-Barakāt al-Baghdādī (d. ca. 560/1165) 85, 95

Abū al-Fidā) (d. 732/1331) 30-1

Abū al-Hudhayl al-'Allāf (d. 227/841 ?) 84

Abū al-Husayn al-Bașrī (d. 436/1044) $106,142,145,152-3$

Abū 'Alī b. Abū Hurayra (d. 345/956) 77

Abū Bakr (d. 13/634) 173

Abū Bakr 'Abd al-'Azīz (d. 363/974) 128

Abū Bakr b. al-Anbārī (d. 328/940) 220

Abū Dāwūd al-Sijistānī (d. 275/889) 183

Abū Dharr (Ibn Taymiyya) 14, 211.

See also translations.

Abū Hurayra (d. 59/678) 41

Abū Ishāq al-Isfarāyīnī (418/1027) 155 n. 77

Abū Khāzim b. Abū Yạlā (d. 527/1133) 152

Abū Lahab 131, 168

Abū Razin al-'Uqaylī (Companion of the Prophet, d.?) 55

Abū Ṭālib al-Makkī (d. 386/996) 129

Abū Ýa'lā b. al-Farrā' (d. 458/1066) 77, $128,155-6,167,216,218$

Acar, Rahim 72 n. 10

acquisition (kasb) explained 165-7; mentioned 112,138 n. 8,139 ,

140 n. $13,141,142$ n. $19,145,153$, 155,165 n. 122

act $\left(f^{\prime} l\right)$

of God: affirmed without modality 48, $57,59,132,161$; wise purpose and causality in (see wise purpose); perpetuity of 80-9; right to praise in 66-7; as voluntary and subsisting in God's essence 95-6; and God's sufficiency 97-101, 165-6 n. 122; goodness of 181-2; freedom of 224; subject to what written for Himself 218; against analogical evaluation of 117-8, 213-6; derived from names and attributes $165-6$ n. 122; and secondary causes 157 ; golden mean in 173; Ibn 'Arabī on 48, 145.

See also will.

human: reality of 106, 120, 153-5;

God as creator and originator of 146-147, 150-6, 173-4; Jahmī/ Jabrī view of God as Agent of 111, 138,155 ; created in a substrate 154-6, 166, 195, 200, 204-6; created through secondary causes 147, 156-166; enacted (maf' $\bar{u} l)$ by God 155-6, 187-9; voluntary and involuntary distinguished 147 , 161, 165-6; pre-Ibn Taymiyya Islamic views of 137-145; prior research on Ibn Taymiyya's view of 136-7; ethical and legal evaluation of 34-9; denial of God's creation of 106-8 (see also Mu'tazilīs; Qadarīs; Majūs); justice in punishing and rewarding 154-6, 195, 197-208; reconciliation of Jabrī and Qadarī views of 152-4. See also will; power; compulsion; acquisition; free choice.

'adam (see nonexistence)

'adhäb (see chastisement)

'Ádil (Ibn Taymiyya) 14, 185, 220-4.

See also translations.

'adl (see justice)

agreeable things (tayyibāt) 37, 43

Ahmad b. Hanbal (d. 241/855) 32, 58-9, 171

Ahmed, Shahab 8 n. 17, 22, 193 n. 71 Akmaliyya (Ibn Taymiyya) 62-3, 67.

See also translations. alam (see pain)

'Alī b. Abī Tālib (d. 40/661) 173

Alläh (God) See existence; essence; names; attributes; act; worship; divinity; wise purpose; justice; will; creation; lordship. 
Āmidī (al-), Sayf al-Dīn (d. 631/1233)

94 n. 100, 140, 217

amr (see command)

analogy (qiyās) 48, 57-9, 62, 115-8, 213-4, 220; al-awlà (see highest similitude); al-shumūl (syllogism) $57-9,62$

anger (ghadab) of God elided 180

annihilation $($ fan $\vec{a}) \quad 23,109$

Anșārī (al-) al-Harawī, Abū Ismāēil (d. 481/ 1089) 109

Anșārī (al-), Abū al-Qāsim (d. 512/1118) 144

anthropomorphism (see assimilation; likening)

antinomianism 23, 108-110, 114-5, 116 n. 74,129

anti-rationalism 20-2, 48

apologetic 25, 29, 68-9

'Aqìda nizämiyya (al-Juwaynī) $\quad 140$

'aql (see reason)

Arabic language 54-5

Arba' ìn (Fakhr al-Dīn al-Rāzī) 10, 152

Aristotle, Aristotelianism 19, 31, 57, 89-90. See also pre-Aristotelian philosophers.

Arnaldez, Roger 129

Ash $^{`}$ arī (al-) (d. 324/935) rational argument in theology 20-1 n. 9; love and will 128; acquisition (kasb) and human acts 112,138 n. 8, 139-140, 155, 166; justice 214-218

Ash'arīs, Ash'arism 6 n. 13, 19, 20 n. 5; voluntarist critique of wise purpose/ causality 74-81, 84, 94-101, 112, 184, 195, 226 n. 68; voluntarist justice 39, 216-220, 224; ethical value 35-7, 39, 117; rational inquiry (nazar) as initial obligation 33; love and will 72-3, 127-9; creation/determination and command 23, 110-4, 129; human acts 136 n. 3, 139-145, 149, 152; denial of secondary causes 157-160; acquisition (kasb) 112, 138 n. 8, 139, 141, 142 n. 19, 165-7; obligation of what one is not able 167; story of three brothers 214-5; prophecy 218-219. See also Ash'arī; Juwaynī; Rāzī.

Ashqar (al-), 'Umar Sulaymān 6 n. 13 asking for help (isti' äna) 15, 24, 26-29, 120-1, 124, 206

așlah (best) 212-5, 226

assimilation (tashbīh) 47-9, 55-6, 59, $173,213-5,219$ associationism (shirk) 28, 34, 43, 49, 60-2, 99, 105, 108, 121-2, 157-161, 167

attributes (sifät)

of God: typology of views on 46-7; affirmed without modality $47-52,59,65-6,118,173$; reality of 48,56 ; connotations and linguistic meaning of 26, 51-6, $74-5,118,172-3$; avoiding negative connotations of $74-5,172-3,236$; of perfection $31,34,56-67,87$, $101,132,185,219$ n. 40, 223-4; praiseworthiness of 66-7; as necessary concomitants to God's essence 67; voluntary $21,24,95-6$; preference of some to others 188-9; Ibn Hanbal on 59-60 n. 150; mentioned 20, 24, $32-3,72-3,76,111$ n. 46, 120-3, 128, 157 n. 84, 166 n. 122, 189, 194. See also names.

human: 50 n. 127, 140, 153-4, 166-7, 207

authorization (idhn) 15, 123, 125 n. 99

Avenger (Muntaqim) 187

Averroes (see Ibn Rushd)

Avicenna (see Ibn Sīnā)

Awzā̄ì (al-) (d. 157/774) 170-1

Azmeh (al-), Aziz 53 n. 131

bad (qabīh) 34-9, 115-7, 182 n. 16, 213

Baghawī (al-) (d. 510/1117) 155

Bājī (al-), Abū al-Walìd (d. 474/1081) 216

Bāqillānī (al-) (d. 403/1013) 139, 167, 216, 218

Barbahārī (al-) (d. 329/941) 19

Basra 108

Bell, Joseph $\quad 3,72-6,100$ n. 118, 128, 133

beneficence (ihssān) of God 38, 52, $63,67,77,97-8,121,194,199$, 220, 222, 227; human 34, 42, 119, 158

benefit (mașlaha, șalāh) -oriented ethic 35-6; opposite detriment (mafsada) 34-8, 45, 130-2, 186; mentioned 66, 74, 98, 120, 127, $130-2,156,165$ n. $122,192,215$, 221 n. 46

best, finest absan 2, 71, 223-4; khayr 224; Mu'tazilī doctrine of așlah 212-5, 226 
best-of-all-possible-worlds theodicy (see optimism)

Bible (Genesis 1:1-2) 91

blame (dhamm), blameworthy 36-8, 45, $74,114,118,144,155,163,184,195-8$, 208, 216, 222

blessing $\left(n i^{\top} m a\right)$ retribution versus unmerited 197-205; mentioned 38, 44, 51, 73, 97, 180, 183-5, 192-5, 206, 208, 215-6, 223

Book, People of the (ahl al-kitāb) 91, 105, 113, 186

Bori, Caterina 8 n. 15

Brahmans (Barāhima) 111

brothers, story of three 214-5

Bukhārī (d. 256/870) 41

Cairo 26

Calder, Norman 3 n. 7 capability (istitāa a) 147-151, 167-8

cause ('illa, sabab), causality in God's will (see wise purpose); wise purpose as final (ghäiyya) 73 n. 13,181 n. 15 , 183, 202, 226 n. 67; divinity as final 28-9, 121; lordship as efficient ( $f \bar{a}^{\mathrm{r}}$ iliyya) 28-9, 121; principle of $32-3,40-2,45$; priority in perfection of 63-4; in creation of human acts before Ibn Taymiyya 138-141, 144-5; complete (tāmm) 146, 147 n. 37, 149, 151, 162, 207; perfect (kāmil) 207; secondary 136-7, 147, 156-168, 207; as instrumental and conditional secondary $136,160-2$; as natural secondary 162-4; God breaking secondary 164; polemics in secondary 158-160; evil attributed to agent $\left(f \bar{a}^{-} i l\right)$ or secondary 179-183, 202-3, 208-9; efficacy of 166-7; in analogy 58 n. 146; Ibn Sīnā's analysis of 28; in commands (Ibn Sīnā) 162 n. 107

chastisement ('adhāb) 12, 37, 44, 156-160, 187, 200, 208, 212, 217, 218 n. 34, 223. See also punishment.

Christians, Christianity 22, 32 n. 43, 41, 43, 87

coercion ilzām 170; ikrāh 171-2, 174

coherence 22, 68-9, 118, 129-130

command (amr) three types 37-9;

modes of expressing creation and 119-129, 173 (see also will; divinity; love); errors in creation and 104-118; coherence of creation and 129-134; and creation in Wásitiyya creed 119-120; and human will and power 147-9, and secondary causes 159-161, 162 n. 107; wise purpose in $37,77,97$, 190; and omission 200, 204; injustice as opposing a 217

commanding (amrī) will, words, etc. $125-6,149$

compatibilism, compatibilist freedom 138-154, 165, 173-4

Compeller (Jabbār) 170-2

compensations ('iwad) 213

complete trust (tawakkul) 27-8, 159, 206

compulsion (jabr) explained 111-2, 169-173; mentioned 106 n. 8, 138-9, 141-5, 165, 170 n. 138. See also Rāzī; Jabrīs.

connotations $51-3,74-5,172,189$; avoiding negative 74-5, 172-3, 236. See also ordinary language; linguistic explanation.

corporealism (tajsim) 47

creation (khalq) for wise purposes

(see wise purpose); perpetuity of 21 ,

76, 80-95; of the world 88-91; of human acts 136-175 (see also act); of evil 179-195, 222-4 (see also evil); of bad deeds as punishment 195-206; of humans weak 205-7; and God's sufficiency 70-2, 75-8, 97-101; and limits to God's power and freedom 184-5, 224-7; modes of expressing command and 119-129, 173 (see also will; lordship; determination); errors in command and 104-118; coherence of command and 129-134; and command in Wásitiyya creed 119-120; as emanation (Ibn Sīnā) 70-2, 76, 82, 88; ex nibilo (Kalām view) 70, 80-5, 91-5. See also Creator; attributes; act.

creative (khaqi) will, words, etc. 73, 125-6, 149

Creator (khāliq) proofs for existence of 31-4, 40-3; prior to creatures in perfection 59, 63-4, 87. See also creation; attributes; act; will; lordship.

$\operatorname{dat}^{\top} \bar{i}$ (motive) 139, 142-3, 152

Dajjāl 122

Dallal, Ahmad 141

Damascus 7, 13-4, 55 
Dar' (Ibn Taymiyya) dated 10-11; rational argument in theology 20-2, 59-62; reason and revelation 29-30; natural constitution 41-3; human acts 148, 151, 170. See also translations.

Davidson, Herbert 93 n. 96

dawām (see perpetuity)

decree (qad $\left.\vec{a}^{\prime}\right) \quad 104-5,114,123-6,158$, 193

Delong-Bas, Natana 5 n. 12

determination (qadar) argument (al-ibtijajj bi-l-) 108-110; two stages of 119-120; of good and evil, belief in 119, 183; equivalent to creation/lordship/ ontological will, etc. 23, 28, 90-1, 105-126, 130, 147, 159-161, 164, 190, 217; Ibn Taymiyya's successors on 5 n. $11 ; 6$ n. 13.

determinative (qadarī) will, realities, etc. $122-7$

determinism 138-144

detriment (mafsada) (see benefit)

dhamm (see blame)

dhull (humility) 132, 191-5, 223

dhunüb (see sins)

discipline, spiritual, evil as $3,132,177$, $191-5,202,223$

disgusting things (khabäith) 37, 199, 222

disobedience (másiyya) 34, 45, 106, $114,119-120,123,126-130$, 134 n. $139,148,154-6,161-2$, 169, 171, 194, 196-204, 212, 217 . 221 n. 46, 223

divinity (ulühiyya, iläbiyya) explained 27-9, 120-2, mentioned 31, 67, 73 n. $12,126,130$ n. 127,195

$d u^{\prime} \vec{a}$ (see invocation)

dualism (thanawiyya) 107-8, 113 n. 63, 114

duality of perspective $136,164,189-190$, 209

education, evil as $177-8,192,202$

efficacy ( $t a^{\prime}$ thir) 136, 140-1, 161-7

efficient cause ('illa fä́ iliyya) 28-9, 121. See also cause.

Egypt 6-7, 11 n. 23, 13, 20

emanation $\quad 70-2,76,82,88,157$

enacted thing $\left(\right.$ maf $\left.^{\prime} \bar{u} l\right) \quad 83,88,96$, 155-6, 187-9

endless chain, infinite regress (tasalsul) 74, 77-81, 86, 91-6, 146 essence (dhät, nafs) of God perpetual causal and voluntary activity in 21 , 76-80, 83-6, 95-6, 122; mentioned through names 59; attributes as concomitants to 67; right to praise and worship 67, 122, 194-5, 206; love for 73; as final cause of existence 100 n. 118; reality of 48 n. 122; Ibn Sīnā on 70-2; Ibn 'Arabī on 46-8; Mu'tazilī cause disjoined from 79 , 97-8; mentioned 33, 81, 101, 110 n. 44, 132, 181 n. 15 eternity translation of terms for 77 n. 24; as time without beginning 87; as timeless 21, 76, 87-8. See also perpetuity.

ethical value $33-9,115-8,213-216$, 219

evil (sharr) types of attribution 179-190; attribution in the Qur'an 179-181; and good in God's names 186-190; as relative, partial, and good by way of generality and wise purpose $73,179-184,187-195,222-3$; as necessary to perfection $177,184-5$, 192; quantitative insignificance of 177 , 185-6; as educational and disciplinary instrument $132,177,191-5,202,223$; attributed to the creature or secondary cause 179-181, 186-190; nonexistence as the origin of 177, 195-208; agent elided 179-180; knowledge of good and $35,109,115-6$; belief in determination of good and 119, 183; and good known by opposites 178; explained by principle of plenitude 178. See also bad; evil deed/thing.

evil deed/thing (sayyi'a) 34-5, 163-5, 196-206; translation 197

existence $(w u j \bar{u} d)$ proofs for God's 2, 31-4, 40-5; nonexistence and evil $177,181,185,188,194,200-8$; better than nonexistence 223 ; oneness of 23 , 110

expiation (takfir) $\quad 132,192-5$

eyes, seeing with two 130

Fakhr al-Dīn al-Rāzī (see Rāzī)

Fakhry, Majid 20

falāsifa (see philosophers)

fan $\vec{a}$ (annihilation) 23, 109

Farābī (al-) (d. 339/950) 31, 46

Fātihạa (Q. 1) 26-9, 121 
Fätiḩa (Ibn Taymiyya) described 15; attribution of evil 182-3, 185; evil as nonexistence 195, 206-209. See also translations.

Fī Fușūss (Ibn Taymiyya) 121-2. See also translations.

fil (see act)

final cause ('illa ghäiyya) and wise purpose 73 n. 13,181 n. 15, 183, 202, 226 n. 67; divinity as 28-9, 121

figh (see theological jurisprudence)

fire $60-1,72$ n. 10, 162-3, 177, 192

fitna (trial) 193

fitra (see natural constitution)

Five Pillars 24-5

foreknowledge of God 105, 108, 115, 168-9

Frank, Richard 140 n. 13, 141-3, 145

free choice (ikhtiyār) 87, 139, 143-5, $155,171-4,224$

freedom God's 12, 14, 75, 99, 224-5 (see also sufficiency); human (see libertarian freedom; compatibilism; free choice)

free-thinkers (zanädiqa) 112

free-will theodicy (see Mu'tazilīis)

fujūr (immorality) 120, 124; opposite piety 115,119

Futūhạat makkiyya (Ibn 'Arabī) 46

Genesis 1:1-2 91

gharad (purpose) 74-75, 172

Ghazālī (al-), Abū Hāmid (d. 505/1111)

33 n. 52, 36, 129, 219 n. 40, 220; optimism 141 n. 17, 225-7; nothing in possibility more wonderful than what is 225; will of God 71, 84-6; human acts 139-143, 159, 161 n. 103; evil and good known by opposites 178; contradictory views of 3 n. 7, 141

Ghengis Khan 122

genus/species 84-5, 87-90, 99

ghadab (anger) of God elided 180

ghinā (see sufficiency)

Gimaret, Daniel 128, 137-145, 156, 165

God (Alläh) See existence; essence; names; attributes; act; will; perfection; worship; divinity; wise purpose; justice; creation; lordship.

golden mean (wasaț) 203. See also median.

Goldziher, Ignaz $\quad 20,47$ n. 119 good deed/thing (hasana) 34-5, 163-5, 196-206; translation of 197

good pleasure (rid̄a) of God 51, 65, 73 (see also love); human 170

good, goodness khayr, husn (see wise purpose; justice; evil); hasan opposite bad 34-9, 115-7, 182 n. 16, 213

Goodman, Lenn 138 n. 9

grace ( $f a d l)$ 199-200, 204-5; in right hand of God 189

Griffel, Frank 219 n. 40

guidance (bidàya) evil as 192, 195; ignorance and punishment 201-3; as secondary cause 161; People of 104-5, 157; mentioned 31, 42-4, 66, $100,105,115-6,121,124-5,144,157$. $174,197-9,204-5,215$

Gwynne, Rosalind 214

hadith reports quoted Both of His hands are right [hands] 188; Every newborn is born with the natural constitution 41 ; The first thing God created was the Pen 91; God did not decree anything for the believer except what is good for him 193; God was, and there was nothing before Him 90; Good is in Your hands, and evil is not [attributed] to You 182; I do not hesitate over anything [Hadith of Supererogatory Works (hadith al-nawäfil)] 123; I have created My servants original believers 42-3; I seek refuge in You from the trial of poverty 193; I take refuge in the complete words of God 124; If one of you stands to pray, God is in front of his face 55; If you had disbursed [in alms] a whole earth full of gold 183; In you are two characteristics that God loves 170 n. 138; Indeed, God is more merciful toward His servants than this mother toward her son 121; A leper, a bald-headed man and a blind man 38 n. 84; My mercy precedes My anger 188; O Lord, this is from You and for You 27; O Messenger of God! Have you seen medicine by which we may be cured 159; O My servants! I have forbidden injustice to Myself 225; The right hand of God is full 189; Should we not leave deeds and trust completely on what has been written? 159; There is not among you one but that he will see his Lord alone 55-6; Truly, God 
determined the determinations of created things 90; Whoever fights so that the word of God is exalted 124; You will see your Lord as you see the sun and the moon 56

hajj/pilgrimage $133,148,155$

Hallaq, Wael 31 n. 41, 40-1, 50, 57

Hamawiyya (Ibn Taymiyya) 54-6. See also translations.

hamd (see praise)

Hanafìs 155-6, 186

Ḥanbalīs $19,33,53,77,109,114,128$, 136 n. $3,137,152,155-6,167,186$, 216, 218

hands of God $\quad 65,188-9$

hard determinism 138-9

harm (darar) opposite naf'(see profit); opposite benefit 66,131 ; mentioned 132-3, 182, 202, 208, 212, 223

hasan (see good)

basana (good deed/thing) 34-5, 163-5, 196-206; translation of 197

Hasana (Ibn Taymiyya) described 14-15, 183 n. 25, 198 n. 87; attribution of evil 179-186; wise purposes in evil 192-5; evil as nonexistence 195-206; God's worthiness of praise 66. See also translations.

Hashwiyya 47

hate, hatred (kurh, karäha) God's (see love); human 70-2

hesitation (taraddud) of God 47, 123

hidāya (see guidance)

highest similitude (mathal a' $\bar{l}$ ), a fortiori argument (qiyās al-awlā) explained 56-62; summarized 68-9; employed $55-6,63-6,131-5,156,161,213$, 223-4; mentioned 1 n. 9, 118, 220; in Ahmad b. Hanbal 59-60 n. 150. See also praise.

bikma (see wise purpose)

Hillī (al-), Ibn al-Mutahhar (d. 726/1325) $10-12,74,107,114,130-133,146$, $152,212-216$

Hourani, George 35, 138 n. 9

budūth (see origination)

humility (dhull) 132, 191-5, 223

'ibāda (see worship)

Iblīs, Iblīisis denial of wise purpose and justice 104-6, 112-4, 117-8; and analogy 115-118; creation of 192 . See also Satan.

Ibn 'Abbās (d. 68/687) 54, 62, 65
Ibn 'Abd al-Hādī (d. 744/1343) 6 n. 14, 10 n. 21,11 n. 23,26

Ibn al-Jawzī (d. 597/1201) 19, 114, 128, $155,159,216$

Ibn al-Rāwandī (4th/10th cent.)

112 n. 59

Ibn al-Zāghūnī (527/1132) 216

Ibn 'Aqiil (d. 513/1119) 19, 33 n. 52, 77,155

Ibn 'Arabī (d. 638/1240) optimism 226-9; God's names and attributes 46-8, 178, 189; human acts 139, 145; evil as nonexistence 178,196 ; ambiguity and paradox 145, 178, 189; critiqued 48, $57,68-9,110,125,226$

Ibn Fūrak, Abū Bakr (406/1015) 197, 218

Ibn Hajar al-'Asqalānī (d. 852/1449) 47 n. 119

Ibn Hanbal (see Ahmad)

Ibn Ḧazm (d. 456/1064) 77

Ibn Kamāl Pasha (d. 940/1534) 222 n. 51

Ibn Mājah (d. 273/887) 187 n. 42

Ibn Qayyim al-Jawziyya (751/1350) 3-8, 194

Ibn Qudāma (d. 620/1223) 19, 53

Ibn Rushayyiq, 'Abd Allāh (d. 749/ 1348-9) 6 n. 14, 10 n. 21

Ibn Rushd (Averroes) (d. 595/1198) 30, 31 n. 41, 46, 89, 90 n. 85, 136

Ibn Sīnā (Avicenna) (d. 428/1037) 31 n. $41,33,57,92-3$; casual analysis 28 ; prophecy and revelation 22, 31, 46; optimism, providence and the role of evil 1-2, 71, 177, 181, 185, 192, 225; evil as nonexistence 177, 196; God's self-sufficiency 70-2, 75-6, 99; human acts 138-143, 173-4; causality in commands $162 \mathrm{n}$. 107; ontology and emanation critiqued $76,80-3,88-9,94$, 96,157

Ibn Taymiyya (d. 728/1328) theodicy summarized 229-237; biography 6-7; Damascus trials 7, 55; influence and significance 4-6; writing style 8, 16; citation of writings by short titles 9 n. 18; writings 6-16. For his ideas, see the respective concepts; for his interaction with others, see the respective groups and persons. See also the respective short titles of his works and translations of Ibn Taymiyya's texts.

ibtil $\vec{a}^{-}$(trial) 38, 192, 193 n. 70, 202 
idhn (authorization) 15, 123, 125 n. 99

iḍlāl (misguidance) 115-6, 121, 124, 204

idolatry (see associationism)

ignorance $(j a b l) \quad 43,191,200-2,208$

ihsān (see beneficence)

Ihyy $\vec{a}$ ' ulūm al-dìn (al-Ghazāīi) 139, 178, 225

İjī (al-), 'Aḍud al-Dīn (d. 756/1355) 140

ikbtiyàr (free choice) 87, 139, 143-5,

155, 171-4, 224

ikhtiyāri (see voluntary)

Ikbtiyāriyya (Ibn Taymiyya) 21-4

ikrāh (coercion) 171-2, 174

ilähiyya (see divinity)

ilhäm (inspiration) 41, 99, 115, 119

İlkhānid Empire 10

'illa (see cause)

illness (marad) 42, 132, 158, 178-181, 190-1, 208

ilzām (coercion) 170

imkān (see possibility)

immorality ( fujūr) 120, 124; opposite piety 115,119

impediment (mäni') 41, 157, 162-4, 207-8

imperfection (naqs) punishment of 38; evil 177-8, 191, 206-8. See also perfection.

impossibility (imtina $\bar{a}^{-}$) of two contraries at one time and place 32, 185; of opposing God's foreknowledge 169.

See also possible; possibility; preponderance.

'Imrān (Ibn Taymiyya) 21-2, 24

'Imrān, 'Alī b. Muhammad 6 n. 14

imtihän (test) 192

imtinā (see impossibility)

Inati, Shams 138 n. 9

'ināya (providence) 2, 4, 71, 177, 225. See also wise purpose; justice.

incomparability (tanzīh) 46-50, 57

independence of God (see sufficiency)

India 111

infallibility of prophets ('isma) $193 \mathrm{n} .71$

infinite regress, endless chain (tasalsul) 74, 77-81, 86, 91-6, 146

injustice, oppression $(z u l m)$ as undeserved harm 212; as acting freely in someone else's property 217 ; as opposing a command 217-8; God's self-forbidding 218,225 ; as putting something in other than its place 220-2; as hateful 42, 64; God's power to commit
224-5; compensation for 213; human 37, 109, 132, 154, 158, 190-3, 201; and purpose (gharad) 74-5. See also justice.

inspiration (ilhäm) 41, 99, 115, 119

intercession (shafäa $a) \quad 125$ n. 99, 158, 206

interpretation (tafsir) $\quad 54-5$. See also reinterpretation.

invocation $\left(d \tilde{u}^{(} \vec{a}\right) \quad 99,132,138$ n. 9, 158, 193, 206, 221

'iqäb (see punishment)

Iräda (Ibn Taymiyya) described 12-13; wise purpose and perpetual activity 75-80, 97-101; secondary causality 159-160; attribution of evil 179-182, 185-190, 197; Iblīs on God's wisdom 113-4. See also translations.

iräda (see will)

Iraq 10

irrational, irrationality $32,69,114$, 129-132, 160, 166, 176; of Mu'tazili view of God's purpose 75, 78, 98

Isfarāyīnī (al-), Abū Ishāa (d. 418/1027) 155 n. 77

Ishmael 146

'ishq (see love)

Ishrāqīs $31 \mathrm{n} .41$

'isma (protection of prophets from sins) $193 \mathrm{n} .71$

isti äna (see asking for help)

istițāa $a$ (capability) 147-151, 167-8

Istițāa a (Ibn Taymiyya) 148-9, 152-3.

See also translations.

istiw $\vec{a}$ (sitting) 46, 54-5

ittih̄ādìs (Unificationalists) 110

'iwad (compensations) 213

Iyās b. Mu'āwiyya (d. 122/740) 217

Jabbār (Compeller) 170-2

Jabr (Ibn Taymiyya) described 13-14; compulsion 171-2; obligation of what one is not able 168-9; attribution of evil 179-185, 191; mentioned 108, 214. See also translations.

jabr (see compulsion)

Jabrīs defined 110-1; human act 106, $110-1,114-8,130,142-5,152-4,166$, 170-3; analogy and ethical value 115-8; reconciliation with Qadarīs 152-4; denial of wise purpose 120 , 204; Fakhr al-Dīn al-Rāzī as 111, $143-5,172$

Jackson, Sherman 53

Jahd (Ibn Taymiyya) 57-8 
jabl (ignorance) 43, 191, 200-2, 208

Jahm b. Șafwān, Jahmīs rational inquiry (nazar) as initial obligation 33; attributes 59 n. $150,84,95,111$ n. 46, 128 ; denial of wise purpose/causality $77,111-2,191,195,216$; human acts 110-111, 138-9, 154-5, 166, 169 jaz $\vec{a}$ (see recompense)

Jews $41,43,87$

jihad $7,133,184,186,194,196$

Jilānī (al-), 'Abd al-Qādir (d. 561/1166) 110

Jubbā'ì (al-), Abū 'Alī (d. 303/916) 142 n. 21,203 n. 102, 214-5

Jubbāì (al-), Abū Hāshim (d. 321/933) 142 n. 21, 166, 203

judgment (bukm) ontological and legislative 120-4, 130; returning to God 77, 79, 98; in analogy 59; names and 105

Julaynad (al-), Muhammad al-Sayyid 6, 143 n. 22

Junayd (al-) (d. 298/910) 109

jurisprudence (see theological jurisprudence)

justice (' $\mathrm{adl}$ ) typology of views on injustice $(z u l m)$ and 212-224; retributive 156, 191, 202-6, 212-6, 222; voluntarist 216-220; as putting things in their places 220-4; as beneficence 220; parallel to wise purpose 105 , 111-4, 117-8, 172, 191, 205, 221-3; parallel to mercy (see mercy); entailing the best possible world 224-8; and creation of human acts 107, 154-6, 164, 195, 202-6; and God's power 224-5; and analogy 213-6; as beloved 42; in one hand of God 189; Jahmī denial of 111; Iblīisi denial of 105, 112-8; human $34,44,132$

Juwaynī (al-) (d. 478/1085) 33 n. 52, 36, 93-4, 216, 218; love and will 73, 127-9; human acts 136, 140, 152

Kalābādhī (al-) (d. 380/990 or 384/994) 155

Kalām theologians (mutakallimūn) method critiqued $21-2,25,31,57$, 69,118 ; reason $32-3$; reinterpretation (ta'wil) 47, 50-5, 64; timeless eternity of God 21, 24, 68, 76, 87-8, 96; creation ex nibilo 80-5, 91-5. See also Ash'arīs; Mu'tazilīs; Māturīdīs; Jabrīs; Qadarīs. kalimāt (words), ontological and religious 122-4, 149

kamäl (see perfection)

Karrāmīs 77, 84, 95, 128, 152, 186

Kasb (Ibn Taymiyya) described 13-14; human acts 151,165, 172; secondary causality 157, 160-4; attribution of evil 179, 190. See also translations.

kayf (see modality)

khabäith (disgusting things) 37, 199, 222

Khalidi, Tarif $11 \mathrm{n} .23$

Khallāl (al-), Abū Bakr (d. 311/923) 170

khalq (see creation)

Khārijīs 173

khațaya (see sins)

Khawd (Ibn Taymiyya) 20-1

khayr (good) (see wise purpose; justice; evil; best)

Khidrr 181

Khudābanda (see Oljeitu)

Kindī (al-) (d. ca. 252/866) 92

kitāb (writing) of God 105, 119, 124, 217

Kitäb al-irshäd (al-Juwaynī) 93

Kitāb al-milal wa al-niḥal (al-Shahrastānī) 113

lack (see nonexistence)

ladhdha (see pleasure)

Lamați (al-), Ahmad b. Mubārak al-Sijilmāsì (d. 1156/1743) 226 n. 67

Laoust, Henri $3-5,11,13$ n. 32, 22-4, 30 n. 39,50 n. $126,72,120$ n. 79, 136, 165

law (shari ${ }^{-} a$, shar $\left.^{\top}\right)$ and theology 24-5; and reason 36-9; deprecation of 7, 13, 108-110, 114, 130, 159-160, 206; mentioned 43, 46, 72-3, 122, 126, 130, 161 n. 103, 167, 178, 213. See also revelation.

lawäzim (see necessary concomitants)

legislative $\left(\operatorname{shar}^{\prime} \bar{i}\right)$ will, words, etc. 27 n. $28,73,122-9,148-9,223$

libertarian freedom defined 138; mentioned 131, 139, 141, 144-5, 154, 205, 214

likening (tamthil) 48-52, 117, 213-4

linguistic explanation (tafsir) $\quad 54-5$. See also ordinary language; connotations.

literalism 22,52

logic Aristotelian 19, 57; rules of 32, 40, 133 
lordship (rubübiyya, rabbäniyya) explained 27-9, 120-2; mentioned $31,59,67,117,126,130$ n. 127 , 195

love

(mahabba): parallel to good pleasure/ command/legislative will, opposite hate $51-2,73,115,118-129,223$; Kalām and Sufi views of will and 51-2, 72-3, 127-9; of wise purpose (in creating what is hated) 73, 80, 97, 133-5; God's sufficiency and self- 75-6, 97-100; as final cause of existence 100 n. 118; attribute of perfection 64-6; for God (in His essence) 27-29, 38, 209; natural constitution 35-6, 42-6, 201

('ishq): passionate 75, 172; God's self- (Ibn Sīnā) 71-2

Ma'arrī (al-), Abū al-'Alä') (d. 449/1058) 112

Ma'bad al-Juhanī (d. 83/703) 108

Madelung, Wilferd 142-3

Madjid, Nurcholish 39 n. 85

mafsada (detriment) (see benefit)

maf $^{\prime} \bar{u} l$ (enacted thing) $83,88,96$, 155-6, 187-9

mahabba (see love)

mahall (see substrate)

Majūs, Majūsīs $\quad 104-8,113$ n. 63, 115, 120

Makari, Victor $136-7,141$

Makdisi, George 7 n. 15, 20 n. 5, 137 n. 5

Mālik b. Anas (d. 179/795) 54

Mālikīs 216

Mamlūks, Bahrī 7, 10

māni' (see impediment)

Manichaeism 107 n. 23, 113 n. 63

Manțiqiyyin (Ibn Taymiyya) 57-8. See also translations.

Maqsad asna (al-Ghazālīi) 220

marad (see illness)

Marātib al-irāda (Ibn Taymiyya) 126

Marmura, Michael 140-1

Marwazī (al-), Abū Bakr (d. 292/905) 170 n. 138

mashì a (see will)

másiyya (see disobedience)

maslaha (see benefit)

Matālib 'āliyya (Fakhr al-Dīn al-Rāzī) 142 n. 19

mathal à $\bar{l}$ (see highest similitude)
Māturīdī (al-), Abū Manșūr (d. 333/944),

Māturīdīs 2, 129 n. 122, 156, 177, 220

Mazdaism 107

Mecca 11

median (wasaț) 173. See also golden mean.

medicine $3,132-3,159,171$

mercy $($ rabma $)$ precedes anger 188 ; written by God for Himself 218; parallel to wise purpose, justice or goodness 37 , $66,97,111,118,121,183-6,190-2$, $195,203-5,212,219-222$; parallel to forgiveness or pardon 162, 187, 194, 221-2; mentioned 31, 38, 52, 163, 215, 218

Messiah, son of Mary 122

Michel, Thomas 31 n. 41, 32 n. 43, 136 n. 3

Michot, Yahya [Jean R.] 11 n. 23, 20 n. 8, 22, 30, 138 n. 9

Minhāj (Ibn Taymiyya) described 10-12, 114; wise purpose and perpetual activity $22,74-100$; human acts 146-156, 166, 171; attribution of evil 179-181, 188; wise purposes in evil 132, 190-4; use of similitudes 56, 130-5; justice 212-6. See also translations.

Minhāj al-karāma (Ibn al-Muțahhar al-Hillī) 10-12, 114

misguidance (iḍāl) 115-6, 121, 124, 204

modality (kayf, takyif) $\quad 48-56,60$ n. 150, $66,161,220$

Mongols 7, 10, 122

Moses $50,125,131,181$

motive $\left(d_{\bar{a}} \bar{a}^{-} \bar{i}\right) \quad 139,142-3,152$

Muhammad b. Ka'b (d. 118/736) 170

Muhammad the Prophet 44, 122, 144, 184-6, 193 n. 71, 198

Muhassal (Fakhr al-Dīn al-Rāzī) 10

mubdith (see originator)

Mujāhid (d. ca. 100-4/718-722) 54

Mujbirīs 106, 111, 113 n. 63. See also Jabrīs.

mulä im (suitable) 34, 36

mumkin (see possible)

munäfir (unsuitable) 34, 36

munkar (see wrong)

Muntaqim (Avenger) 187

Murji'î' 106

Mushrikīs 104-8, 115

Muslim (d. 261/875) 14, 41, 225

Mưtabar (Abū al-Barakāt al-Baghdādī) 85 
mutafalsifa 31 n. 41. See also philosophers.

mutakallimūn (see Kalām theologians)

Mu'tazilīs, Mu'tazilism free-will theodicy 1-2, 177, 213, 216; rational inquiry (nazar) as initial obligation 33; objectivist ethics 35-7; assimilation and objectivist ethics 116-8, 213-216, 219; reinterpretation $\left(t a^{\prime} w \bar{l} l\right)$ and denial of attributes 54-5, $111 \mathrm{n}$. 46; purpose, sufficiency and origination in God 71, 74-9, 84, 95-8, 100, 194-5, 213; human creation of acts $105-8,114$, $143-5,149,157-160,184,212-3$; acts interpreted deterministically 141-3, 152-4; polemic against voluntarism and determinism 113-4, 130, 133, 154; will and command 124, 127; purposes in evil 177; retributive justice 196, 212-6; purpose of creation as human benefit $75,77,97-8,213$, 215; best (aslab) 212-5, 226; and Shīi theology 11, 95, 107, 149; Basran and Baghdādī 213. See also Jubbāì̄ं; 'Abd al-Jabbār; Abū al-Husayn al-Bașrīi; Hilli.

naf (see profit)

nafs (see soul; essence)

names (asm $\vec{a})$ of God affirmed without modality 47-53, 62, 65-6; essence mentioned through 59; manifestation of $121,178,189$; relation to evil 186-9; conjoined 188; ninety-nine 178, 187; Allāh 27; Jabbār (Compeller) 170-2; Muntaqim (Avenger) 187. See also attributes.

naql (see tradition)

naqs (see imperfection)

natural constitution ( fitra) explained 39-44; mentioned 20, 45-6, 57 n. 146, 62-3, 66, 109, 201-3, 216, 221. See also reason.

natural causality 162-4

nazar (rational inquiry) 33, 43

Naẓzāàm (al-) (d. 231/845) 166, 212 n. 3 necessary concomitants (lawazim) of

God 67, 70-2, 87, 99 n. 118, 101; evils as 181,182 n. $20,185,207$; mentioned $35,42,133$

need (see sufficiency)

negation of God's attributes (see stripping away)
Neoplatonism $31,75-6,81$ n. 44, 86, 140-1

ni'ma (see blessing)

Noah 92, 168-9

nominalism $50-2,65$

nonexistence, privation, lack ('adam) and evil 177-9, 195-6, 200-8

Nubuwwāt (Ibn Taymiyya) 44, 98, 218-9. See also translations.

oaths 127

obedience $\left(t \bar{a}^{-} a\right)$ 12, 23-4, 28, 31-2, $73,90,97,99,106,109,114,119-122$, $126-7,155,161-2,172,196-200,203$, 214, 217

obligation (taklif) of what one is not able ( $m \bar{a}$ la yutáq) 165-9; power that is the condition for imposing 149-151; rational inquiry (nazar) as the initial 33-4, 43; mentioned 98, 123, 214

Oljeitu (d. 716/1316) 10, 11 n. 24

omission (tark) 200-4

omnipotence (see power)

oneness of existence (wahdat al-wujüd) 23, 110

ontological (kawnī) will, words, etc. 27 n. $28,122-7,149$

opposites, good and evil known by 178 oppression (see injustice)

optimism, best-of-all-possible-worlds theodicy introduced 1-6; perpetual, defined 5; as a threat to God's power 224-7; summary of Ibn Taymiyya's 4-5, 229-237. See also wise purpose; justice; Ibn Sīnā; Ibn 'Arabī; al-Ghazālī. ordinary language $22,53,68,171-2$. See also linguistic explanation; connotations.

origination (budūth) of events from eternity 77-80, 88-95; in God's essence 74, 79, 95-6; God as eternal, complete cause precludes $78,81-3$; possible from eternity 83-6; and secondary causality 160 ; of human acts by God 146, 147 n. 17, 152-4; of acts by humans (but not creation) 152-4 originator (mubdith) argument for God's existence 33-4, 40; argument for God's creation of human acts 146, 152-4; prior to originated in perfection 59,63

Ormsby, Eric 3 n. 7, 225-6 
pain (alam) 34-6, 42-4, 183-7, 208-9 paradox $65,69,97,129,137,138,145$, 178,189

passionate love ('ishq) 71-2, 75, 172

Pazdawi (al-) (d. 593/1099) 129 n. 122

perfection (kamäl) as perpetual activity 21, 76, 87-8, 91, 94, 96, 99; attributes of/ascribing the highest/ exoneration from imperfection 25 , $31,56-69,87-8,132,156,161,169$, 220, 223-4, 227 (see also highest similitude); of the created order 177-8, 181, 184-5, 222, 225 n. 64, 226-7; exists only when wise purpose requires 101; known through imperfection 178 , 185; and God's self-sufficiency/wise purpose 78-80, 81 n. 44, 97-101, 165-6 n. 122; of natural constitution 44-5; mentioned 34, 70, 150, 165, 191, 194 n. 71, 207

Perho, Irmeli 5 n. 11, 8

perpetuity (dawām) of causal, voluntary and creative activity in God 21, 24, 76-96, 99, 122; of emanation 82

Persia 10, 107

perspective switching $161,164,168-9$, $189,200,205$; duality of 136,164 , 189-190, 209

perversity 200-2

Pharaoh 122, 131, 192

Philoponus, John (d. ca. 570) 92-3 philosophers (faläsifa) $21 \mathrm{n} .10,34$, 57, 140, 186; identified 31; revelation and prophecy $22,31,46-7,50,69$, 219 n. 40; God and the world 21, 68, 77-88, 94, 96, 142, 160, 226. See also Neoplatonism; Ibn Sīnā; Ibn Rushd. piety $($ taqwā) 159, 221; opposite immorality 115,119

Pilgrimage/Hajj 133, 148, 155

Plato 4

pleasure (ladhdha) 34-5, 42-4, 97-8, 133, 201, 208

plenitude, principle of 178

polytheism (see associationism) possibility (imkān) of other than what is 223-7; of divine injustice 217-8, 224-5

possible (mumkin) eternal versus preceded by nonexistence 88-9; need for preponderator or cause to bring into existence 33, 40, 83-5; 142-4, 153; the Necessary Existent more perfect than 63 potency (quwwa) reason as 32; natural constitution as 41 ; in human acts 147, 151, 168; mentioned 157, 164 power (qudra) of God: Qadarī/Mu'tazilī denial of $105,108,118,158-9$; optimism as a threat to 224-7; mentioned 52, 60, 63-5, 85-7, 119-122, 173-4, 218

human: reality of 120; Ash'arī views of 139-145; determining and legislative $147-152$; as secondary cause 147 , 156-161, 166-9

praise (hamd), praiseworthy ascribing to God the highest 25-6, 59, 62-3, 66-9, 132, 220, 223-5 (see also highest similitude); for God in His essence 29, 66-7, 194-5, 206; God's self-sufficiency and self- 75, 97-100; in human acts 36, 126, 144, 163, 165 n. 122, 214-6, 222. See also worship; love.

pre-Aristotelian philosophers 90, 95-6 predestination (see determination) predetermination (see determination) preponderance (tarji $\mathrm{z}$ ) principle of 40-1, 45, 142; in God's will 45, 84-7, 91, 94; in creation of human acts 142-6, 147 n. 37, 149, 152-4; of good over evil 182 n. 16, 183 n. 22, 185 principles $(u s \bar{u} l)$ of religion (al-din) 19-20; and branches (fur $\bar{u})$ 24-5 privation (see nonexistence) Proclus (d. 485) 81 n. 44 profit (naf') opposite harm (darar) $34-8,42,45,52,97-8,110,131,165$, $186,201,203$; in acts $74,126,130$, 184, 192, 195, 199, 202, 205-6, 221. See also benefit. prophecy (nubuwwa) 22, 44-6, 111, 184, 193-4 n. 71, 218-9

Prophet Muhammad 44, 122, 144, 184-6, 193 n. 71, 198

protection of prophets from sins (isma) 193 n. 71

providence ('ināya) 2, 4, 71, 177, 225. See also wise purpose; justice. punishment ('iqäb) before and after guidance $37-8,200-4$; for lack of good deeds 204-6; naturalistic 163-4; mentioned 36, 45, 51-2, 105 , 116, 155-161, 173, 177, 187, 193, 197-209, 212-223. See also justice. purpose (gharad) 74-75, 172 
qabīh (bad) 34-9, 115-7, 182 n. 16, 213 qad $\vec{a}$ (decree) 104-5, 114, 123-6, 158, 193

qadar (see determination)

Qadarīs defined 105-108; God's will and the human act 114-8, 124, 130, 142, 147, 152-4, 170, 173, 204; denial of foreknowledge 108, 169 n. 135; analogy and ethical value $115-118$; reconciliation with Jabrīs 152-4; wise purpose 194; justice 212, 217. See also Mu'tazilīs.

Qaffāl (al-), Abū Bakr (d. 365/975-6) 77

$q \vec{a}$ im bi (see subsisting in)

qiyās (see analogy)

qiyās al-awlà (a fortiori argument) (see highest similitude)

qiyās al-shumūl (syllogism) 57-9, 62

Qudra (Ibn Taymiyya) 97. See also translations.

qudra (see power)

Qur'an as authoritative 19-22, 27-34, 43, 49, 54, 58 n. 146, 59-62, 68-9, 168-170; translation of $21 \mathrm{n} .10$; verses cited: (Q. 1:2) 27, 180; (Q. 1:5) 27, 29, 121; (Q. 1:6-7) 180; (Q. 2:6) 144; (Q. 2:22) 49; (Q. 2:26) 157; (Q. 2:30) 191; (Q. 2:34) 113 n. 60; (Q. 2:105) 205; (Q. 2:128) 146; (Q. 2:143) 173; (Q. 2:165) 49; (Q. 2:185) 124; (Q. 2:205) 128; (Q. 2:216) 193; (Q. 2:225) 49; (Q. 2:255) 125 n. 99; (Q. 2:258) 198; (Q. 2:286) 165; (Q. 3:4) 187; (Q. 3:7) 54; (Q. 3:26) 224 n. 58; (Q. 3:83) 172; (Q. 3:97) 97, 148, 168; (Q. 3:144) 185 n. 33; (Q. 3:147) 27; (Q. 3:154) 93; (Q. 3:164) 185 n. 33; (Q. 3:165) 180; (Q. 3:187) 26; (Q. 3:191) 182; (Q. 4:26) 49; (Q. 4:26-7) 124; (Q. 4:40) 221; (Q. 4:58) 124; (Q. 4:65-104) 196; (Q. 4:78-9) 14-5, 196-200; (Q. 4:79) 180, 206; (Q. 4:93) 50; (Q. 4:164) 50; (Q. 5:6) 124; (Q. 5:16) 157, 161, 198; (Q. 5:48) 169; (Q. 5:54) 49; (Q. 5:64) 189 n. 48; (Q. 5:98) 187; (Q. 6:53) 185 n. 33; (Q. 6:73) 182 n. 19; (Q. 6:110) 198; (Q. 6:125) 124, 204; (Q. 6:148) 105, 174; (Q. 6:165) 187; (Q. 7:11-18) 113 n. 60; (Q. 7:12) 117; (Q. 7:23) 180; (Q. 7:57) 157; (Q. 7:157) 37; (Q. 7:172) 41; (Q. 9:14) 160; (Q. 9:33)
25; (Q. 11:7) 90; (Q. 11:20) 149, 151; (Q. 11:36) 169; (Q. 11:88) 27;

(Q. 11:123) 27; (Q. 13:15) 172;

(Q. 13:16) 179; (Q. 13:30) 27;

(Q. 13:35) 89; (Q. 14:28) 185 n. 33;

(Q. 15:28-42) 113 n. 60; (Q. 15:39)

116; (Q. 15:49-50) 187; (Q. 15:85)

182; (Q. 15:85-6) 182 n. 19; (Q. 16:17)

62, 87; (Q. 16:57-62) 61-2;

(Q. 16:58-62) 60 n. 151; (Q. 16:60) 55-6, 59, 62, 68, 223; (Q. 16:74) 49;

(Q. 16:75) 63; (Q. 16:93) 115;

(Q. 17:5) 125; (Q. 17:12) 117;

(Q. 17:15) 37; (Q. 17:23) 58, 125;

(Q. 17:61-5) 113 n. 60; (Q. 17:99)

60; (Q. 18:50) 113 n. 60; (Q. 18:60-82)

181; (Q. 18:101) 149; (Q. 19:42) 63;

(Q. 19:65) 49; (Q. 19:83) 125;

(Q. 20:5) 54; (Q. 20:13) 96; (Q. 20:14)

23; (Q. 20:112) 221; (Q. 20:116-120)

113 n. 60; (Q. 21:16-7) 182 n. 19;

(Q. 21:23) 190; (Q. 21:107) 185

n. 33, 186 n. 34; (Q. 23:76) 223;

(Q. 23:115) 182 n. 19; (Q. 23:118) 27;

(Q. 25:2) 49, 179; (Q. 25:59) 54;

(Q. 26:80) 180; (Q. 27:88) 97, 182;

(Q. 28:20) 131, 234; (Q. 28:59) 37;

(Q. 29:6) 97; (Q. 30:27) 60; (Q. 30:28)

60 n. 151, 61-2; (Q. 30:30) 41;

(Q. 32:7) 97; (Q. 32:22) 182, 187,

224 n. 58; (Q. 32:24) 146; (Q. 32:43)

215; (Q. 36:78-81) 60; (Q. 36:82) 124;

(Q. 38:27) 182 n. 19, 191; (Q. 38:54)

89; (Q. 38:71-85) 113 n. 60; (Q. 39:7)

128; (Q. 39:23) 224 n. 58; (Q. 39:62)

179; (Q. 41:11) 90; (Q. 41:53)

190; (Q. 42:11) 47, 49, 52, 68;

(Q. 43:16-19) 61; (Q. 43:55-6) 192;

(Q. 44:39) 182 n. 19; (Q. 47:38)

50 n. 127; (Q. 51:49) 157; (Q. 51:56)

23, 97 n. 111, 124; (Q. 53:19-23) 61;

(Q. 53:38-9) 221; (Q. 57:4) 46, 49,

54-5; (Q. 59:23) 170; (Q. 59:24)

50; (Q. 61:5) 204; (Q. 62:2) 125;

(Q. 66:12) 124; (Q. 70:19-21) 146;

(Q. 72:10) 180; (Q. 74:11) 59 n. 150;

(Q. 75:36) 182 n. 19; (Q. 79:26)

192; (Q. 81:28-9) 120, 147, 153;

(Q. 85:12-4) 187; (Q. 91) 115;

(Q. 91:8) 115; (Q. 92:8-10) 204;

(Q. 99:7-8) 221; (Q. 111:3) 168;

(Q. 112) 62, 182, 188; (Q. 112:3-4)

49; (Q. 113:1-2) 180

quwwa (see potency) 
rabbāniyya (see lordship)

rabma (see mercy)

Rahman, Fazlur 3 n. 8, 5, 24

rational inquiry (nazar) 33, 43; objectivism (ethics) 35, 45

rationalism 22, 237. See also reason; highest similitude; theological jurisprudence.

Rāzì (al-), Fakhr al-Dīn (d. 606/1209) 10,11 n. 23, 29, 33 n. 52, 34, 57, 79 n. 33,89 n. $76,92,94$ n. 100,95 , 129, 214, 217, 219 n. 40; as a Jabrī $111,143-5,172$; compulsion ( $j a b r$ ) of human acts 111-2, 139, 141-6, 152-4, 169, 172-3; acquisition (kasb) rejected $112,142 \mathrm{n} .19$; obligation of what one is not able 168; late-life skepticism 144 n. 26; evil 186 n. 34, 196 n. 77 reality (haqiqa) of God's essence, attributes and acts 48, 54-6; of human action $114,120,138$ n. 9, 154-5, 161, 164, 173-5; ontological and legislative 122; of extramental universals 57, 65; ambiguous character of (Ibn 'Arabī) 145

reason ('aql), rational ('aqlì) defined 32-3; correspondence of revelation with 20, 29-32; and Law 32-9; and rational argument in theology (see theological jurisprudence; highest similitude); and natural constitution 39-40; mentioned 23, 43-8, 53, 56, 62-3, 89, 100, $109,118,133,144,153,159-163$, 213,219

recompense $(j a z \vec{a})$ unmerited reward and blessing versus retribution 197-205; mentioned 39, 163, 221 n. 46. See also justice.

reinterpretation $\left(t a^{3} w \bar{l} l\right) \quad 47,54-5,64$ religious $(\operatorname{din} \bar{\imath})$ will, words, etc. $122-8$, 223

repentance $($ tawba) 27, 53, 97-100, 109, 132, 191-5, 199, 203, 223

retribution (see recompense; justice)

revelation (shar') correspondence of reason with 21, 29-32, 44, 56; mentioned 19, 26, 29, 34-7, 44-8, 53 n. 131, 56, 75, 168, 189-190, 218. See also tradition; law. reward $($ thawāb) retributive versus unmerited 197-200; naturalistic 163-4; Mu'tazilī purpose for creating humans as opportunity to earn 77 , 213-4; mentioned 36, 73-5, 98-9, 105 ,
$116,128,155,158,161,173,192-4$, 212, 216-7, 221. See also justice. rid̄a (see good pleasure)

Riḍā, Rashīd 5

right (ma'rüf) 37, 42, 44, 124, 214

rubübiyya (see lordship)

sabab (see cause)

Salaf (the pious early Muslims) 1,6, 20-2, 31, 49, 54, 57-9, 69, 95 n. 103, 96,107 n. $17,117-8,126,130,151$, 168

Sālim, Muhammad Rashād 10, 11 n. 23 sam' (see tradition)

Satan 6 n. 13, 201, 205. See also Iblīs. satans (shayātin) 43, 45, 110, 125, 134, 194

sayyi a (evil deed/thing) 34-5, 163-5,

196-206, translation of 197

Schimmel, Annemarie 3

secondary cause (see cause)

seeing with two eyes 130

self-sufficiency (see sufficiency)

service ('ibāda) (see worship)

shafä́a (intercession) 15, 125 n. 99, 158, 206

Shāfîis $77,144,155$

Shahrastānī (al-) (d. 548/1153) 113, 140, 220

Shams (Ibn Taymiyya) 115-8, 219.

See also translations.

Shams, Muhammad 'Uzayr 6 n. 14

shar' (see revelation; law)

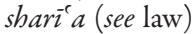

sharr (see evil)

Shifä (Ibn Sīnā) 177

Shihadeh, Ayman 142 n. 19, 144 n. 26

Shīìis, Shīism 10-11, 77-8, 84, 95, $107,114,130-2,149,152,173$, 212-3

shirk (see associationism)

similitudes (amthāl) in Qur'ān translation 21 n. 10; in theology (see highest similitude)

sins (dhunūb, khațāya) lead to virtues $132,191-5$; origin of 197-205,

208-9; initial 205; mentioned 27, $109,163,177,182$ n. 16, 212, 218, 221-3

sitting (istiwa $\vec{a}) \quad 46,54-5$

skepticism 69, 113-4, 129, 144 n. 26

soft determinism 138-9

soul, self (nafs) ignorance and evil in 191, 196-208; weakness of 205-207; celestial 
106 n. 14; mentioned 34, 41-3, 52, 98 , $115,123,139,151,158,163,165$

species/genus 84-5, 87-90, 99

spiritual discipline, evil as $3,132,177$, 191-5, 202, 223

stripping away (tátil) 49-50, 67, 83, 173

Stroumsa, Gedaliahu 107 n. 23, 113 n. 63

Stroumsa, Sarah 107 n. 23, 113 n. 63 subsisting in (qäim bi) God 79, 81, 85, 95-6, 98; humans 146, 153-4, 183 n. 22,200

substrate (mahall) God as 79, 95; human as 139, 154-6, 166, 195, 200, 204-6; receptive to burning 158 sufficiency (ghina) of God 78, 96-101, 194; human 208; Ibn Sinnā on 70-2; Joseph Bell on 72-5

Sufīs, Sufism $48,57,75,77,121,129$, 134 n. 139, 145, 149, 155, 225; of Ibn Taymiyya 7; critiqued 7, 23, 103-5, 108-115, 116 n. 74, 129; and evil as instrumental 3, 177, 186, 195

Sufyān al-Thawrī (d. 161/778) 170 n. 138,171

Suhrawārdī (al-) (d. 587/1191) 31 n. 41 suitable (mulä im) 34, 36

Sulaymān b. Saḥmān (d. 1349/1930) 6 n. 13

Sunna (Abū Bakr al-Khallāl) 170

Sunna 19-21, 30, 43, 49, 58 n. 146, 64, $168,170,179,187$ n. 42 ; People of the 95, 119, 173-4. See also hadith reports quoted.

Sunnīs, Sunnism 4, 77-8, 95, 128, 144, 152, 155, 167, 173, 193 n. 71, 199,

211 n. 2; al-Hillîs critique of 10-12, 74, $114,130,132$

supplication (see asking for help)

switching perspectives $161,164,168-9$, 189, 200, 205

syllogism (qiyās al-shumūl) 57-9, 62

Syria $7,11 \mathrm{n} .23,30$

$\operatorname{tă}^{-} a$ (see obedience)

Tabarī (al-) (d. 310/923) 54, 197 n. 83 Tadmuriyya (Ibn Taymiyya) described 13; God's attributes 49-52, 65-6; creation and command 104-113; secondary causality 157-163. See also translations.

Tafsìr (Fakhr al-Dīn al-Rāzī) 143-5, 186 n. 34 , tafsir (interpretation, linguistic explanation) 54-5

Tahäfut al-falāsifa (al-Ghazālī) 84

tajsim (corporealism) 47

takfir (expiation) 132, 192-5

taklif (see obligation)

takyif (see modality)

Tálīqāt (Ibn Sīnā) 139

Tamīmī (al-), Abū al-Hasan (d. 371/982) 77

tamthil (likening) 48-52, 117, 213-4

tanzīh (incomparability) 46-50, 57

țāa (ability) 147-8, 165-9

taqwā (piety) 221, 159; opposite immorality 115,119

taraddud (hesitation) 47, 123

Taraddud (Ibn Taymiyya) 123-5. See also translations.

tarjīh (see preponderance)

tark (omission) 200-4

tasalsul (endless chain, infinite regress) $74,77-81,86,91-6,146$

tashbih (see assimilation)

ta'thir (efficacy) 136, 140-1, 161-7

ta'tīl (stripping away) 49-50, 67, 83, 173

tawakkul (complete trust) 27-8, 159, 206

tawba (see repentance)

tawhid (uniqueness, exclusivity of God) 28-9, 121-2, 195

ta'will(reinterpretation) 47, 54-5, 64

tayyibāt (agreeable things) 37, 43

teleological ethic 35-6,39, 45

test (imtihān) 192

thanawiyya (dualism) 107-8, 113 n. 63, 114

thawāb (see reward)

Thawrī (al-) (see Sufyān al-Thawrī)

theistic subjectivism 35

theodicy defined 1-3; free-will (see Mu'tazilis); best-of-all-possible-worlds (see optimism). See also justice.

theological jurisprudence, theological figh 19-26, 46-69; apologetic and philosophical quality of 22, 25, 29, 68-9; instrumentalized 23-5. See also highest similitude.

three brothers, story of 214-5

Throne ('arsh) of God 46, 54-5

Thulth (Ibn Taymiyya) 182, 187-9. See also translations.

Tilimsānī (al-) (d. 690/1291) 110

time (see perpetuity; eternity) 
Tirmidhī (al-) (d. 279/892) 187

Torah (Genesis 1:1-2) 91

tradition, revealed (naql, sam) correspondence to reason 29-32; mentioned 17, 20, 22, 46, 48, 54, 56, $62,65,90,118,153$. See also revelation; hadith reports quoted

transcendence (see incomparability) translations of Ibn Taymiyya's texts (two lines or more) (MF 6:56-7) 24-5; (MF 8:198) 130; (MF 12:229) 39-40; ' $A b d$ al-Qädir (MF 10:481) 42; Abū Dharr (MF 18:139) 217, (MF 18:145) 217, (MF 18:145) 217-8; Abū al-Fid $\vec{a}$ (159) 31; 'Ádil (JR 123-4) 221, (JR 130) 222, (JR 133) 223, (JR 136) 223, (JR 136) 223-4, (JR 142) 227; Akmaliyya (MF 6:83) 67, (MF 6:84) 67; $\operatorname{Dar}^{\prime}$ (1:61) 151, (8:455) 42-3; Fätiba (MF 14:17) 207, (MF 14:18) 207, (MF 14:19) 207, (MF 14:21) 183, 183 n. 22; Fì Fusūus (MF 2:398-9) 121, (MF 2:406) 122; Fì Wujūb (MF 1:48) 40-41; Furqān (MF 13:138) 32; Hamawiyya (MF 5:36-7) 54, (MF 5:107) 55-6; Hasana (MF 14:248-9) 196, (MF 14:259) 198, (MF 14:261) 199, (MF 14:266) 183, (MF 14:278) 200, (MF 14:287) 201, (MF 14:290) 201, (MF 14:296) 201, (MF 14:299) 183, (MF 14:300) 184, (MF 14:302) 194, (MF 14:309) 194, (MF 14:318-9) 193, (MF 14:331) 203, (MF 14:333-5) 203-4, (MF 14:336-7) 204-5; Ihtijāj (MF 8:310) 34, (MF 8:312) 44; Iräda (MF 8:81) 77, (MF 8:84) 79, (MF 8:97) 190, (MF 8:89-90) 98, (MF 8:93) 185, (MF 8:93-4) 186, (MF 8:95) 188, (MF 8:96) 186-7, (MF 8:115) 113, (MF 8:138) 159, (MF 8:138-9) 159, (MF 8:144) 99, (MF 8:145) 100, (MF 8:146) 101; Isfăāniyya (49) 58-9, (87) 66; Istițā'a (MF 8:372) 148, (MF 8:375) 153; Ittih̄ädiyyin (MF 2:255) 110; Jabr (MF 8:459) 155, (MF 8:460) 111, (MF 8:462-3) 171, (MF 8:463-4) 171, (MF 8:464) 171, (MF 8:465) 172, (MF 8:511) 191, (MF 8:512) 183 n. 22, (MF 8:513) 191; Jawāb (4:395) 39; Kasb (MF 8:387) 165-6 n. 122, (MF 8:390) 161, (MF 8:396) 163; Mahabba (214)
48; Manțiqiyyin (424) 34; Minhāj (1:146/1:35-6) 80, (1:147-8/1:36) 81, (1:148/1:36) 81-2, 83 (1:148-9/1:36) 83, (1:149/1:36) 88, (1:236/1:62) 89, $(1: 327 / 1: 89) 96,(1: 344 / 1: 95) 82$, (1:351/1:97) 83, (1:360/1:100) 90, (1:371/1:103) 87, (1:397-8/1:111) 166, (1:405/1:113) 86, (1:407/1:113) 150, (1:407/1:113-4) 150, (1:421/1:117) 99, (1:422-3/1:118) 95, (2:314/1:215) 74, (2:400/1:227) 194 n. 71, (3:14/1:266) 74, (3:29/1:269) 36, (3:29/1:270) 36, (3:71-2/2:6) 150, (3:142/2:25) 181, $(3: 144 / 2: 25) 181,(3: 146 / 2: 26) 147$, (3:172/2:32) 131, (3:176/2:33) 131-2, (3:198-9/2:39) 215, (3:269/2:57) 147 n. 37, (5:410/3:102) 188; Nubuwwāt (111) 99-100 n. 118, (430-1) 44; Qiyās (MF 20:505) 57; Qudra (MF 8:21) 64, (MF 8:35-6) 97, (MF 8:36) 97, (MF 8:37) 97; Shams (MF 16:235) 115, (MF 16:236) 107 n. 17, (MF 16:237-8) 116, (MF 16:238) 116, (MF 16:239-240) 116-7, (MF 16:241) 117-8, (MF 16:246) 112; Shirk (MF 1:89) 27-8, (MF 1:90) 130 n. 127; $T \bar{a}^{\mathrm{r}} a(\mathrm{MF}$ 8:446) 114; Tadmuriyya (MF 3:3-4) 49, (MF 3:28) 66, (MF 3:30) 66, (MF 3:111-3) 105 and 158, (MF 3:115) 36; Tabsin al-'aql (MF 8:434) 37; Talbis (2:454) 28-9; Taraddud (MF 18:131-3) 123-5; Thulth (MF 17:64) 126, (MF 17:94-5) 187; Wãsița (MF 1:137) 162; Wäsitiyya (MF 3:141) 173, (MF 3:149-150) 119-120; Wașiyya kubrā (MF 3:373-4) 173-4

trial of Ibn Taymiyya 7, 55; as spiritual discipline (ibtilä), fitna) 38, 192-3

Ṭūsì (al-), Naṣir al-Dīn (d. 672/1274) 31 n. 41,152

ulūbiyya (see divinity)

'Umar b. al-Khatțāb (d. 23/644) 173

Umayyads 108

Unificationists (ittihāa diss) 110

uniqueness of God (tawhid) 28-9, $121-2,195$

universals $50-2,57,65-6$

unsuitable (munäfir) $\quad 34,36$

usūl (see principles)

'Uthmān b. 'Affān (d. 35/656) 173 
voluntarism (see Ash'arīs)

voluntarist ethic 35,45

voluntary (ikhtiyāri $\bar{i}$ attributes and acts of God 21, 24, 79, 96; human acts 138, 142-4, 147, 152-3, 161, 164-6, 172. See also free choice.

wahdat al-wujūd (oneness of existence) 23,110

wasat (median, golden mean) 173, 203

Wäsitiyya (Ibn Taymiyya) 119-120, 173.

See also translations.

weakness, human 205-7

will

(irāda, mashì ${ }^{3} a$ ) of God: irāda and mashì a distinguished 127-8; Kalām and Sufi views of iräda and mashì $a$ 73, 124, 127-9; as mashìa 105, 119-120, 124, 157, 207; creative/ ontological/determinative and commanding/legislative/religious 28, 73, 123-130, 223 (see also love); coherence of 130-5; and lordship and divinity 126; causality, wise purpose and rationality in 74-80, 98-9, 181

n. 15; perpetual dynamism of 21 , $81,84-7,92-6$; and secondary causality 161-4; al-Ghazālī 71, 84-6; Ibn Sinā 71-2; mentioned 51-2, $108-110,115,118,121,169,173-5$, 204-7, 216-8, 224 n. 58

(iräda) human: God's creation of 41-2, 138-154, 173-4, 202; reality of 120, 161, 173-5; Ibn Taymiyya's imprecision in 149-151; obligation of 167-9; and compulsion 138, 171-2. See also free choice.

Williams, Wesley 59-60 n. 150

wise purpose, wisdom (hikma) in God's will, creation and acts, classification of views on 76-8; affirmed in creation, determination, lordship, etc. 121-3, 127, 164, 172, 189-195, 202, 214; affirmed in unbelief, disobedience, evil, what is hated, etc. $73,133-5,156,181-5$, 203-5, 208, 216, 222-3; in placement of body parts 219-220; in commanding but not creating 130-3; in specific evils
190-5 (see also evil); in commands 37-8; and Iblīs/Satan 6 n. 13, 192; as causal 73 n. 13, 74-81, 92, 94, 181 n. 15; 183, 202; and God's perfection and self-sufficiency $72-5$, 78, 81 n. 44, 97-101; and an endless chain into the future 80-1; and an endless chain into the past 79-95; and originating events in God's essence 79-80, 95-6; love of 73-5, 80, 97, 133-5; and divinity and essence 194-5; and right to praise 66, 195; basis in Qur'an and Hadith for 182; and justice and retribution 221; in parallel to justice and mercy (see mercy; justice); and prophecy 218-9; and purpose (gharad) 74-5; as translation of bikma 73 n. 13; Joseph Bell on 72-6; in Ibn Sīnā 177 n. 2; denial of (see Iblīs; Ash'arīs; Jahm b. Șafwān) words (kalimät), ontological and religious 122-4, 149

worship ('ibäda) meaning and scope 23-9, 121-2; includes speaking well about God 25 (see also theological jurisprudence; highest similitude); God's worthiness of 29, 64-7, 73, 122, 195 . 206; of God alone, epistemological foundations for $34,38,42,68$; humans created to 42-5, 97 n. 111, 124; incorrect 50, 57, 63, 108-110, 125, 202; translation of 'ibäda as 23.

See also praise. writing (kitāb) of God 105, 119, 124, 217

wrong (munkar) 37, 42, 44, 124, 163, 214

yang/yin dialectic 189

Zāhirīs $\quad 57,77$

Zamakhsharī (al-) (d. 538/1144) 37

n. 81,152 n. 62,197 n. 83

zanādiqa (see free-thinkers)

Zoroastrians, Zoroastrianism $\quad 41-3,107$, 113 n. 63

Zubaydī (al-) (d. 149/766) 170

zulm (see injustice) 